U.S. Geological Survey National Water-Quality Assessment Program

\title{
Simulations of Groundwater Flow and Particle-Tracking Analysis in the Zone of Contribution to a Public-Supply Well in San Antonio, Texas
}

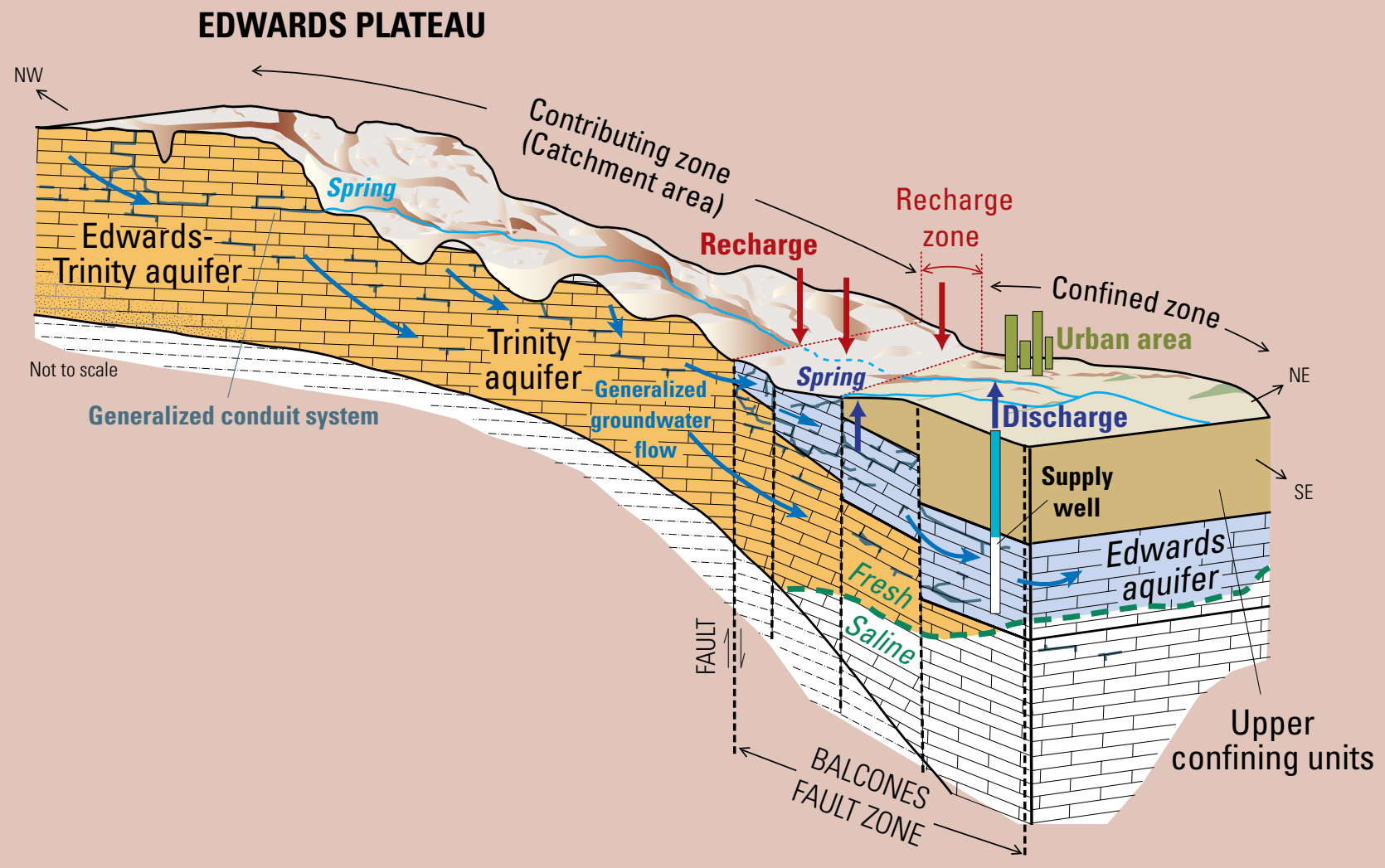

Scientific Investigations Report 2011-5149 



\section{Simulations of Groundwater Flow and Particle-Tracking Analysis in the Zone of Contribution to a Public-Supply Well in San Antonio, Texas}

By Richard J. Lindgren, Natalie A. Houston, MaryLynn Musgrove, Lynne S.

Fahlquist, and Leon J. Kauffman

U.S. Geological Survey National Water-Quality Assessment Program

Scientific Investigations Report 2011-5149 


\title{
U.S. Department of the Interior \\ KEN SALAZAR, Secretary \\ U.S. Geological Survey \\ Marcia K. McNutt, Director
}

\section{U.S. Geological Survey, Reston, Virginia: 2011}

\author{
This and other USGS information products are available at http://store.usgs.gov/ \\ U.S. Geological Survey \\ Box 25286, Denver Federal Center \\ Denver, CO 80225 \\ To learn about the USGS and its information products visit http://www.usgs.gov/ \\ 1-888-ASK-USGS
}

\footnotetext{
Any use of trade, product, or firm names is for descriptive purposes only and does not imply endorsement by the U.S. Government.

Although this report is in the public domain, permission must be secured from the individual copyright owners to reproduce any copyrighted materials contained within this report.
}

Suggested citation:

Lindgren, R.J., Houston, N.A., Musgrove, M., Fahlquist, L.S., and Kauffman, L.J., 2011, Simulations of groundwater flow and particle-tracking analysis in the zone of contribution to a public-supply well in San Antonio, Texas: U.S. Geological Survey Scientific Investigations Report 2011-5149, 93 p. 


\section{Foreword}

The U.S. Geological Survey (USGS) is committed to providing the Nation with reliable scientific information that helps to enhance and protect the overall quality of life and that facilitates effective management of water, biological, energy, and mineral resources (http://www.usgs.gov/). Information on the Nation's water resources is critical to ensuring longterm availability of water that is safe for drinking and recreation and is suitable for industry, irrigation, and fish and wildlife. Population growth and increasing demands for water make the availability of that water, measured in terms of quantity and quality, even more essential to the long-term sustainability of our communities and ecosystems.

The USGS implemented the National Water-Quality Assessment (NAWQA) Program in 1991 to support national, regional, State, and local information needs and decisions related to water-quality management and policy (http://water.usgs.gov/nawqa). The NAWQA Program is designed to answer: What is the quality of our Nation's streams and groundwater? How are conditions changing over time? How do natural features and human activities affect the quality of streams and groundwater, and where are those effects most pronounced? By combining information on water chemistry, physical characteristics, stream habitat, and aquatic life, the NAWQA Program aims to provide science-based insights for current and emerging water issues and priorities. From 1991 to 2001, the NAWQA Program completed interdisciplinary assessments and established a baseline understanding of water-quality conditions in 51 of the Nation's river basins and aquifers, referred to as Study Units (http://water.usgs.gov/nawqa/ studies/study_units.html).

National and regional assessments are ongoing in the second decade (2001-12) of the NAWQA Program as 42 of the 51 Study Units are selectively reassessed. These assessments extend the findings in the Study Units by determining water-quality status and trends at sites that have been consistently monitored for more than a decade, and filling critical gaps in characterizing the quality of surface water and groundwater. For example, increased emphasis has been placed on assessing the quality of source water and finished water associated with many of the Nation's largest community water systems. During the second decade, NAWQA is addressing five national priority topics that build an understanding of how natural features and human activities affect water quality, and establish links between sources of contaminants, the transport of those contaminants through the hydrologic system, and the potential effects of contaminants on humans and aquatic ecosystems. Included are studies on the fate of agricultural chemicals, effects of urbanization on stream ecosystems, bioaccumulation of mercury in stream ecosystems, effects of nutrient enrichment on aquatic ecosystems, and transport of contaminants to public-supply wells. In addition, national syntheses of information on pesticides, volatile organic compounds (VOCs), nutrients, trace elements, and aquatic ecology are continuing.

The USGS aims to disseminate credible, timely, and relevant science information to address practical and effective water-resource management and strategies that protect and restore water quality. We hope this NAWQA publication will provide you with insights and information to meet your needs and will foster increased citizen awareness and involvement in the protection and restoration of our Nation's waters.

The USGS recognizes that a national assessment by a single program cannot address all water-resource issues of interest. External coordination at all levels is critical for cost-effective management, regulation, and conservation of our Nation's water resources. The NAWQA Program, therefore, depends on advice and information from other agencies-Federal, State, regional, interstate, Tribal, and local — as well as nongovernmental organizations, industry, academia, and other stakeholder groups. Your assistance and suggestions are greatly appreciated.

William H. Werkheiser

USGS Associate Director for Water 



\section{Contents}

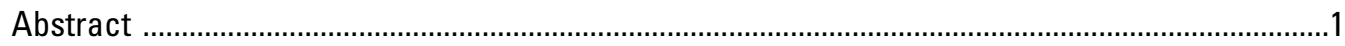

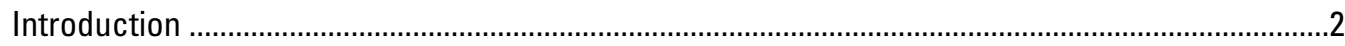

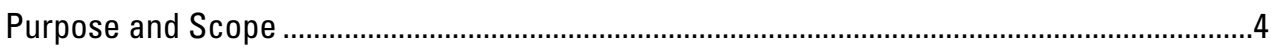

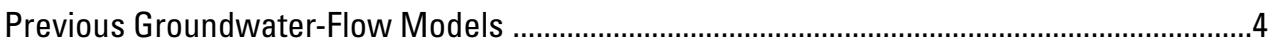

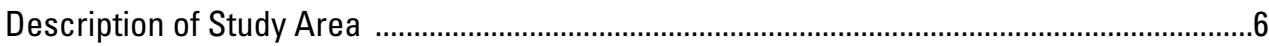

Methods of Investigation .................................................................................................

Data Collection and Analysis ........................................................................................

Development and Application of Groundwater-Flow and Particle-Tracking

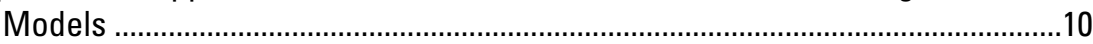

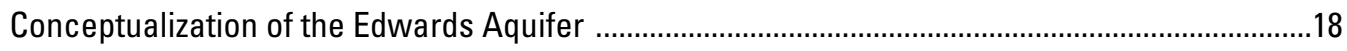

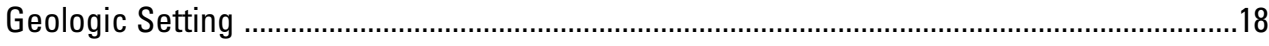

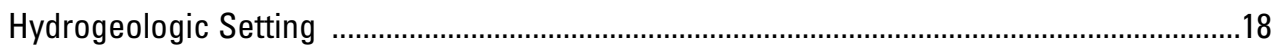

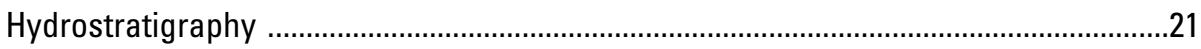

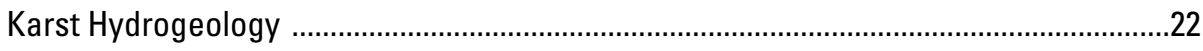

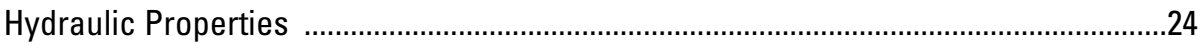

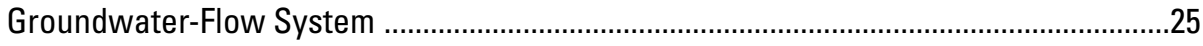

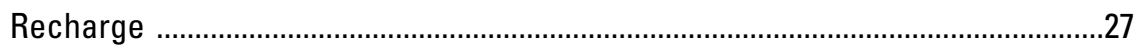

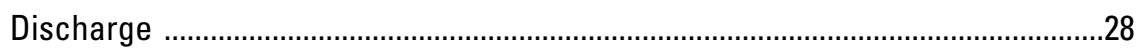

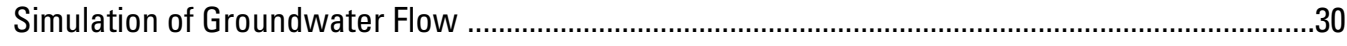

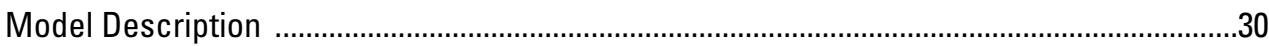

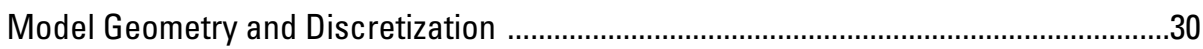

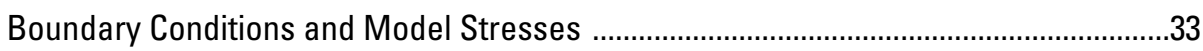

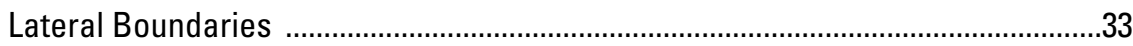

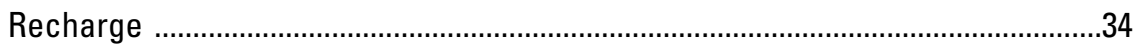

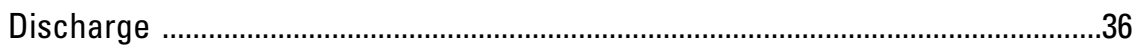

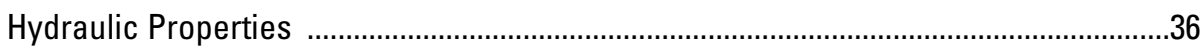

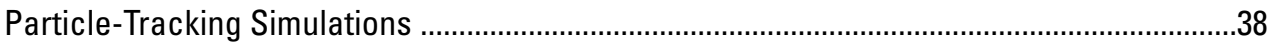

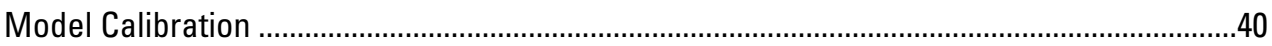

Parameter Sensitivity ................................................................................................

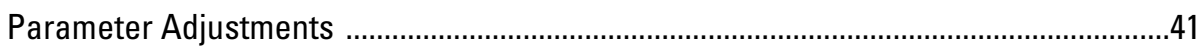

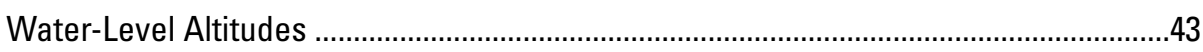

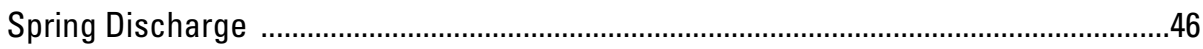

Age-Tracer Concentrations ........................................................................................

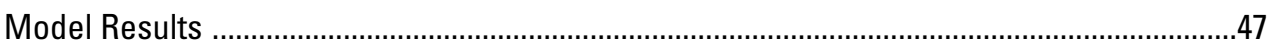

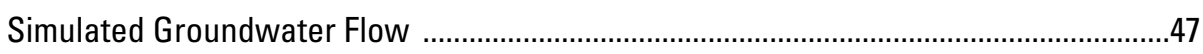

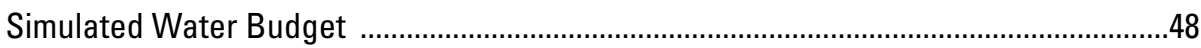

Simulated Zones of Contribution, Areas Contributing Recharge, and Water Particle Ages ..............................................................................................

Supply-Well Vulnerability to Natural and Anthropogenic Contaminants ...............................54

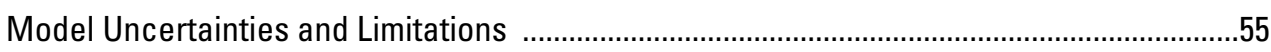

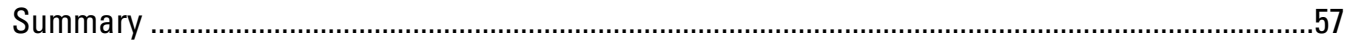

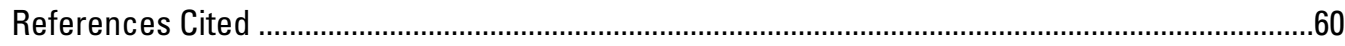




\section{Figures}

1. Map showing location of regional-scale and local-scale model areas, Edwards aquifer segments, and physiographic regions, San Antonio region, Texas

2. Map showing location of regional-scale and local-scale model areas, hydrogeologic zones, and catchment area (upper parts of stream basins that contribute recharge) of the Edwards aquifer, San Antonio region, Texas

3. Map showing local-scale study area and locations of public-supply wells, monitoring wells, and tritium observation wells for the local-scale model, San Antonio region, Texas

4. Map showing model grid, boundary conditions, and simulated subzones of the recharge zone of the Edwards aquifer for the local-scale model, San Antonio region, Texas

5. Graph showing daily mean water-level altitudes from continuous water-level recorders in monitoring wells in the local-scale study area, September 12, 2007, to February 9, 2010, San Antonio region, Texas

6. Map showing local-scale study area and locations of observation wells used to monitor water-level altitudes for inclusion in the local-scale model, San Antonio region, Texas

7. Graphs showing $A$, annual groundwater withdrawals for San Antonio Water System wells, and $B$, estimated annual groundwater recharge to the Edwards aquifer in the local-scale study area, 1969-2009, San Antonio region, Texas

8. Graphs showing measured water-level altitudes in well W38 (Bexar County index well, J-17) for $A$, November 12, 1932, to February 28, 2010, and $B$, January 1, 2000, to February 28, 2010, San Antonio region, Texas

9. Graphs showing measured water-level altitudes, San Antonio region, Texas. $A$, Well W32, January 24, 2000, to March 3, 2010. $B$, Well W25, January 24, 2000, to July 22, 2009. C, Well W4, January 26, 2000, to February 24, 2010

10. Chart showing correlation of Cretaceous stratigraphic units and hydrogeologic units and their relative permeabilities in the San Antonio region, Texas

11. Map showing thickness and measured potentiometric surface of the Edwards aquifer in the local-scale study area, October 27 to November 2, 2001, San Antonio region, Texas

12. Map showing locations and displacements of faults simulated in the local-scale model, San Antonio region, Texas

13. Conceptual diagram showing generalized north to south hydrogeologic section and potential paths of groundwater flow for the local-scale study area, San Antonio region, Texas

14. Map showing locations of groundwater withdrawal wells in the local-scale study area, San Antonio region, Texas

15. Conceptual diagrams showing generalized hydrogeologic sections and measured and simulated tritium concentrations in the local-scale study area, San Antonio region, Texas

16. Map showing distribution of calibrated horizontal hydraulic conductivity in hydrogeologic units $2-4,6-8$, and $10-11$ in the local-scale model, San Antonio region, Texas .

17. Map showing distribution of calibrated horizontal hydraulic conductivity in hydrogeologic units 5 and 9 in the local-scale model, San Antonio region, Texas

18. Map showing distribution of calibrated horizontal anisotropy in the local-scale model, San Antonio region, Texas

19. Graph showing composite sensitivity of the parameters used to calibrate the local-scale model, San Antonio region, Texas 
20. Map showing simulated potentiometric surface and water-level residuals for the local-scale model, San Antonio region, Texas

21. Graph showing simulated relative to measured water-level altitudes for the localscale model, steady-state simulation, San Antonio region, Texas

22. Graph showing simulated relative to measured tritium concentrations for the localscale model, steady-state simulation, San Antonio region, Texas

23. Graph showing simulated relative to measured tritium concentrations in the selected public-supply well and monitoring wells for the local-scale model, steady-state simulation, San Antonio region, Texas

24. Schematic diagram showing simulated water-budget components for the localscale model, steady-state simulation, San Antonio region, Texas

25. Map showing simulated areas contributing recharge, age of water particles derived from simulated particle traveltimes, and particle pathlines for the selected public-supply well, San Antonio region, Texas

26. Map showing simulated areas contributing recharge, age of water particles derived from simulated particle traveltimes, and particle pathlines for the Zarzamora monitoring wells, San Antonio region, Texas

27. Map showing simulated areas contributing recharge, age of water particles derived from simulated particle traveltimes, and particle pathlines for the Timberhill monitoring wells, San Antonio region, Texas

28. Graph showing simulated age of water particles reaching the selected publicsupply well, San Antonio region, Texas

29. Graph showing simulated time series of hypothetical contaminant concentrations at the selected public-supply well based on 30 years of contaminant input (at relative concentration of 1 ) in the simulated areas contributing recharge, San Antonio region, Texas

\section{Tables}

1. Summary of groundwater wells used in the local-scale model, San Antonio region, Texas

2. Summary of water-level measurements obtained from monitoring and observation wells used in the local-scale model, San Antonio region, Texas

3. Hydraulic properties for the Edwards aquifer, San Antonio region, Texas

4. Estimated recharge rates, by recharge subzone, in the local-scale model area during 2001, San Antonio region, Texas

5. Mean daily and mean annual groundwater-withdrawal rates from municipal, industrial, irrigation, and livestock wells in the local-scale study area during 2001, San Antonio region, Texas

6. Measured and simulated water-level altitudes and springflows and the differences between measured and simulated water-level altitudes and springflows (residuals) for the local-scale model, steady-state simulation, San Antonio region, Texas

7. Hydrogeologic units used in the local-scale model, San Antonio region, Texas ............87

8. Summary of specified flux by model boundary in the local-scale model, San Antonio region, Texas .

9. Initial and calibrated values for hydraulic conductivity parameters used in the local-scale groundwater-flow and particle-tracking simulations, San Antonio region, Texas.

10. Initial and calibrated values for additional parameters used in the local-scale groundwater-flow and particle-tracking simulations, San Antonio region, Texas 
11. Measured and simulated tritium concentrations and the differences between measured and simulated tritium concentrations (residuals) for the local-scale model, steady-state simulation, San Antonio region, Texas

12. Simulated annual water budget for the local-scale model, steady-state simulation, San Antonio region, Texas

13. Simulated particle ages, minimum, mean, and maximum at monitoring wells and at the selected public-supply well, San Antonio region, Texas

\section{Conversion Factors}

\section{SI to Inch/Pound}

\begin{tabular}{|c|c|c|}
\hline Multiply & By & To obtain \\
\hline \multicolumn{3}{|c|}{ Length } \\
\hline centimeter (cm) & 0.3937 & inch (in.) \\
\hline millimeter (mm) & 0.03937 & inch (in.) \\
\hline meter (m) & 3.281 & foot $(\mathrm{ft})$ \\
\hline kilometer (km) & 0.6214 & mile (mi) \\
\hline kilometer $(\mathrm{km})$ & 0.5400 & mile, nautical (nmi) \\
\hline meter (m) & 1.094 & yard (yd) \\
\hline \multicolumn{3}{|c|}{ Area } \\
\hline square meter $\left(\mathrm{m}^{2}\right)$ & 0.0002471 & acre \\
\hline hectare (ha) & 2.471 & acre \\
\hline square hectometer $\left(\mathrm{hm}^{2}\right)$ & 2.471 & acre \\
\hline square kilometer $\left(\mathrm{km}^{2}\right)$ & 247.1 & acre \\
\hline square centimeter $\left(\mathrm{cm}^{2}\right)$ & 0.001076 & square foot $\left(\mathrm{ft}^{2}\right)$ \\
\hline square meter $\left(\mathrm{m}^{2}\right)$ & 10.76 & square foot $\left(\mathrm{ft}^{2}\right)$ \\
\hline square centimeter $\left(\mathrm{cm}^{2}\right)$ & 0.1550 & square inch $\left(i^{2}\right)$ \\
\hline square hectometer $\left(\mathrm{hm}^{2}\right)$ & 0.003861 & $\begin{array}{l}\text { section ( } 640 \text { acres or } 1 \text { square } \\
\text { mile) }\end{array}$ \\
\hline hectare (ha) & 0.003861 & square mile $\left(\mathrm{mi}^{2}\right)$ \\
\hline square kilometer $\left(\mathrm{km}^{2}\right)$ & 0.3861 & square mile $\left(\mathrm{mi}^{2}\right)$ \\
\hline \multicolumn{3}{|c|}{ Volume } \\
\hline cubic meter $\left(\mathrm{m}^{3}\right)$ & 6.290 & $\begin{array}{l}\text { barrel (petroleum, } 1 \text { barrel }=42 \\
\text { gal) }\end{array}$ \\
\hline liter (L) & 33.82 & ounce, fluid (fl. oz) \\
\hline liter (L) & 2.113 & pint (pt) \\
\hline liter (L) & 1.057 & quart (qt) \\
\hline liter (L) & 0.2642 & gallon (gal) \\
\hline cubic meter $\left(\mathrm{m}^{3}\right)$ & 264.2 & gallon (gal) \\
\hline cubic decimeter $\left(\mathrm{dm}^{3}\right)$ & 0.2642 & gallon (gal) \\
\hline cubic meter $\left(\mathrm{m}^{3}\right)$ & 0.0002642 & million gallons (Mgal) \\
\hline cubic centimeter $\left(\mathrm{cm}^{3}\right)$ & 0.06102 & cubic inch $\left(\mathrm{in}^{3}\right)$ \\
\hline cubic decimeter $\left(\mathrm{dm}^{3}\right)$ & 61.02 & cubic inch $\left(\mathrm{in}^{3}\right)$ \\
\hline
\end{tabular}




\begin{tabular}{|c|c|c|}
\hline Multiply & By & To obtain \\
\hline liter (L) & 61.02 & cubic inch $\left(\right.$ in $\left.^{3}\right)$ \\
\hline cubic decimeter $\left(\mathrm{dm}^{3}\right)$ & 0.03531 & cubic foot $\left(\mathrm{ft}^{3}\right)$ \\
\hline cubic meter $\left(\mathrm{m}^{3}\right)$ & 35.31 & cubic foot $\left(\mathrm{ft}^{3}\right)$ \\
\hline cubic meter $\left(\mathrm{m}^{3}\right)$ & 1.308 & cubic yard $\left(\mathrm{yd}^{3}\right)$ \\
\hline cubic kilometer $\left(\mathrm{km}^{3}\right)$ & 0.2399 & cubic mile $\left(\mathrm{mi}^{3}\right)$ \\
\hline cubic meter $\left(\mathrm{m}^{3}\right)$ & 0.0008107 & acre-foot (acre-ft) \\
\hline cubic hectometer $\left(\mathrm{hm}^{3}\right)$ & 810.7 & acre-foot (acre-ft) \\
\hline \multicolumn{3}{|c|}{ Flow rate } \\
\hline cubic meter per second $\left(\mathrm{m}^{3} / \mathrm{s}\right)$ & 70.07 & acre-foot per day (acre-ft/d) \\
\hline cubic meter per minute (m3/min) & 0.000811 & acre-foot per minute (acre-ft/min) \\
\hline cubic meter per year (m³/yr) & 0.000811 & acre-foot per year (acre-ft/yr) \\
\hline $\begin{array}{l}\text { cubic hectometer per year }\left(\mathrm{hm}^{3} /\right. \\
\text { yr) }\end{array}$ & 811.03 & acre-foot per year (acre-ft/yr) \\
\hline meter per second (m/s) & 3.281 & foot per second $(\mathrm{ft} / \mathrm{s})$ \\
\hline meter per minute (m/min) & 3.281 & foot per minute (ft/min) \\
\hline meter per hour (m/hr) & 3.281 & foot per hour (ft/hr) \\
\hline meter per day (m/d) & 3.281 & foot per day (ft/d) \\
\hline meter per year (m/yr) & 3.281 & foot per year ft/yr) \\
\hline cubic meter per second $\left(\mathrm{m}^{3} / \mathrm{s}\right)$ & 35.31 & cubic foot per second $\left(\mathrm{ft}^{3} / \mathrm{s}\right)$ \\
\hline $\begin{array}{l}\text { cubic meter per second per } \\
\text { square kilometer }\left[\left(\mathrm{m}^{3} / \mathrm{s}\right) / \mathrm{km}^{2}\right]\end{array}$ & 91.49 & $\begin{array}{l}\text { cubic foot per second per square } \\
\text { mile }\left[\left(\mathrm{ft}^{3} / \mathrm{s}\right) / \mathrm{mi}^{2}\right]\end{array}$ \\
\hline cubic meter per day $\left(\mathrm{m}^{3} / \mathrm{d}\right)$ & 35.31 & cubic foot per day $\left(\mathrm{ft}^{3} / \mathrm{d}\right)$ \\
\hline liter per second (L/s) & 15.85 & gallon per minute (gal/min) \\
\hline cubic meter per day (m³/d) & 264.2 & gallon per day (gal/d) \\
\hline $\begin{array}{l}\text { cubic meter per day per square } \\
\text { kilometer }\left[\left(\mathrm{m}^{3} / \mathrm{d}\right) / \mathrm{km}^{2}\right]\end{array}$ & 684.28 & $\begin{array}{l}\text { gallon per day per square mile } \\
{\left[(\mathrm{gal} / \mathrm{d}) / \mathrm{mi}^{2}\right]}\end{array}$ \\
\hline cubic meter per second $\left(\mathrm{m}^{3} / \mathrm{s}\right)$ & 22.83 & million gallons per day (Mgal/d) \\
\hline $\begin{array}{l}\text { cubic meter per day per square } \\
\text { kilometer }\left[\left(\mathrm{m}^{3} / \mathrm{d}\right) / \mathrm{km}^{2}\right]\end{array}$ & 0.0006844 & $\begin{array}{l}\text { million gallons per day per square } \\
\text { mile }\left[(\mathrm{Mgal} / \mathrm{d}) / \mathrm{mi}^{2}\right]\end{array}$ \\
\hline cubic meter per hour (m³/h) & 39.37 & inch per hour (in/h) \\
\hline centimeter per year (cm/yr) & 0.3937 & inch per year (in/yr) \\
\hline millimeter per year (mm/yr) & 0.03937 & inch per year (in/yr) \\
\hline kilometer per hour $(\mathrm{km} / \mathrm{h})$ & 0.6214 & mile per hour (mi/h) \\
\hline \multicolumn{3}{|c|}{ Specific capacity } \\
\hline $\begin{array}{l}\text { liter per second per meter } \\
{[(\mathrm{L} / \mathrm{s}) / \mathrm{m}]}\end{array}$ & 4.831 & $\begin{array}{l}\text { gallon per minute per foot [(gal/ } \\
\min ) / \mathrm{ft}]\end{array}$ \\
\hline \multicolumn{3}{|c|}{ Hydraulic conductivity } \\
\hline meter per day $(\mathrm{m} / \mathrm{d})$ & 3.281 & foot per day (ft/d) \\
\hline \multicolumn{3}{|c|}{ Hydraulic gradient } \\
\hline meter per kilometer $(\mathrm{m} / \mathrm{km})$ & 5.27983 & foot per mile (ft/mi) \\
\hline \multicolumn{3}{|c|}{ Transmissivity* } \\
\hline meter squared per day $\left(\mathrm{m}^{2} / \mathrm{d}\right)$ & 10.76 & foot squared per day $\left(\mathrm{ft}^{2} / \mathrm{d}\right)$ \\
\hline \multicolumn{3}{|c|}{ Application rate } \\
\hline $\begin{array}{l}\text { kilograms per hectare per year } \\
{[(\mathrm{kg} / \mathrm{ha}) / \mathrm{yr}]}\end{array}$ & 0.8921 & $\begin{array}{l}\text { pounds per acre per year } \\
\text { [(lb/acre }) / \mathrm{yr}]\end{array}$ \\
\hline
\end{tabular}


Temperature in degrees Celsius $\left({ }^{\circ} \mathrm{C}\right)$ may be converted to degrees Fahrenheit $\left({ }^{\circ} \mathrm{F}\right)$ as follows:

$$
{ }^{\circ} \mathrm{F}=\left(1.8 \times{ }^{\circ} \mathrm{C}\right)+32
$$

Temperature in degrees Fahrenheit $\left({ }^{\circ} \mathrm{F}\right)$ may be converted to degrees Celsius $\left({ }^{\circ} \mathrm{C}\right)$ as follows:

$$
{ }^{\circ} \mathrm{C}=\left({ }^{\circ} \mathrm{F}-32\right) / 1.8
$$

Vertical coordinate information is referenced to the North American Vertical Datum of 1988 (NAVD 88) and to the National Geodetic Vertical Datum of 1929 (NGVD 29) for Bexar County index well (J-17).

Altitude, as used in this report, refers to distance above the vertical datum.

*Transmissivity: The standard unit for transmissivity is cubic foot per day per square foot times foot of aquifer thickness [(ft $\left.\left.\mathrm{ft}^{3} / \mathrm{d}\right) / \mathrm{ft}^{2}\right] \mathrm{ft}$. In this report, the mathematically reduced form, foot squared per day $\left(\mathrm{ft}^{2} / \mathrm{d}\right)$, is used for convenience.

Specific conductance is given in microsiemens per centimeter at 25 degrees Celsius $(\mu \mathrm{S} / \mathrm{cm}$ at $\left.25^{\circ} \mathrm{C}\right)$.

Concentrations of chemical constituents in water are given either in milligrams per liter (mg/L) or micrograms per liter $(\mu \mathrm{g} / \mathrm{L})$. 


\title{
Simulations of Groundwater Flow and Particle-Tracking Analysis in the Zone of Contribution to a Public-Supply Well in San Antonio, Texas
}

\author{
By Richard J. Lindgren, Natalie A. Houston, MaryLynn Musgrove, Lynne S. Fahlquist, and Leon J. Kauffman
}

\section{Abstract}

In 2006, a public-supply well in San Antonio, Texas, was selected for intensive study to assess the vulnerability of public-supply wells in the Edwards aquifer to contamination by a variety of compounds. A local-scale, steady-state, three-dimensional numerical groundwater-flow model was developed and used in this study to evaluate the movement of water and solutes from recharge areas to the selected publicsupply well. Particle tracking was used to compute flow paths and advective traveltimes throughout the model area and to delineate the areas contributing recharge and zone of contribution for the selected public-supply well.

The local-scale model grid has a finer vertical discretization than do previous regional Edwards aquifer models and incorporates refined parameter zones corresponding with multiple (10) hydrogeologic units representing the Edwards aquifer. In the Edwards aquifer, high matrix porosity and permeability likely are overshadowed by high permeability developed in structurally influenced karstic conduit systems that transmit water into, through, and out of the aquifer system. The complexity of the aquifer system in the local-scale study area is further increased by numerous faults with varying vertical displacements. The extensive faulting results in the juxtaposition of hydrogeologic units with differing hydraulic properties and has appreciable effects on groundwater flow in the Edwards aquifer. The local-scale model simulations use the MODFLOW Hydrogeologic-Unit Flow Package and include two hydrogeologic units with high hydraulic conductivities (one or more orders of magnitude higher than for the other simulated hydrogeologic units) that are intended to simulate fast flow paths attributable to karst features. The two "conduit" hydrogeologic units of the Edwards aquifer represent the lower 8 meters of the leached and collapsed members and the Kirschberg evaporite member of the Edwards Group. The MODFLOW Horizontal-Flow Barrier Package was used to simulate faults in the local-scale model. The assumption was made that the degree to which a fault acts as a barrier to groundwater flow is proportional to the fault displacement. The final calibrated hydraulic-conductance values ranged from 0.01 to 0.2 per day for fault displacements ranging from 0 to more than 100 percent of the total aquifer thickness.
The calibrated steady-state simulation generally reproduces the spatial distribution of measured water-level altitudes. Simulated water-level altitudes were within 9.0 meters of measured water-level altitudes at 74 of the 84 wells used as targets for the local-scale model for the calibrated steady-state simulation. The overall mean absolute difference between simulated and measured water-level altitudes is 4.2 meters, and the mean algebraic difference is 1.9 meters. The simulated springflow for San Antonio Springs was 7.7 percent greater and for San Pedro Springs was 4.2 percent less than the median measured springflow. Simulated tritium concentrations were within 0.14 tritium units of measured tritium concentrations for 11 of the 13 local-scale study tritium observations from the 10 local-scale study wells used to calibrate the steady-state local-scale model, with a mean absolute difference between simulated and measured tritium concentrations of 0.11 tritium units and a mean algebraic difference of -0.04 tritium units. Simulated tritium concentrations in the selected public-supply well during November 2007 were within 0.09 tritium units of the measured concentrations, with the exception of the shallowest observation from the well.

The steady-state simulation water budget indicates that recharge occurring in the local-scale study area accounts for 31.8 percent of the sources of water to the Edwards aquifer in the local-scale model area and that inflow through the model boundaries contributes 68.2 percent. Most of the flow into the local-scale model area through the model boundaries occurs through the western and southern boundaries, 58.2 and 39.6 percent, respectively. The largest discharges from the Edwards aquifer in the local-scale model area are boundary outflow (71.4 percent) and withdrawals by wells (24.9 percent). Most of the flow out of the local-scale model area through the model boundaries occurs through the southern and eastern boundaries, 54.2 and 39.6 percent, respectively.

The simulated zones of contribution for the selected public-supply well, Timberhill well nest, and Zarzamora well nest extend to the north, northeast, and northwest from each site in the confined zone of the aquifer into the recharge zone, where all recharge to the aquifer occurs. The area contributing recharge for the selected public-supply well has the greatest extent. The area contributing recharge for the Timberhill well nest encompasses approximately the western one-half of the 
area contributing recharge for the selected public-supply well, and that for the Zarzamora well nest encompasses approximately the eastern two-thirds of the area contributing recharge for the selected public-supply well.

Simulated particle ages ranged from less than 1 day to more than 1,900 years in the 10 local-scale study wells (13 local-scale study tritium observations) used to calibrate the local-scale model. The simulated mean particle ages for the tritium observations representing selected well depths (shallow, intermediate, and deep) ranged from 2.5 to 15 years. The minimum (youngest) mean particle ages for the selected public-supply well and the Timberhill monitoring wells were for the intermediate well depth, while the youngest mean particle age for the Zarzamora monitoring wells was for the intermediate and deep well depth. The maximum (oldest) mean particle ages for the selected public-supply well and the Zarzamora monitoring wells were for the shallow well depth. The mean of simulated particle ages for tritium observations representing well depths open to the simulated conduit hydrogeologic units was 3.8 years, whereas the mean of simulated particle ages for tritium observations representing well depths not open to the simulated conduit hydrogeologic units was 9.6 years.

The effect of short-circuit pathways, for example karst conduits, in the flow system on the movement of young water to the selected public-supply well could greatly alter contaminant arrival times compared to what might be expected from advection in a system without short circuiting. In a forecasting exercise, the simulated concentrations showed rapid initial response at the beginning and end of chemical input, followed by more gradual response as older water moved through the system. The nature of karst groundwater flow, where flow predominantly occurs via conduit flow paths, could lead to relatively rapid water quality responses to land-use changes. Results from the forecasting exercise indicate that timescales for change in the quality of water from the selected publicsupply well could be on the order of a few years to decades for land-use changes that occur over days to decades, which has implications for source-water protection strategies that rely on land-use change to achieve water-quality objectives.

\section{Introduction}

Groundwater accounts for nearly all of the water supply in south-central Texas, and the Edwards aquifer is the principal source. The Edwards aquifer in the Balcones fault zone of south-central Texas (fig. 1) is one of the most permeable and most productive aquifers in the world (Maclay, 1995). The aquifer consists of regionally extensive carbonate rocks that crop out within the Edwards Plateau and the Balcones fault zone and underlie the Gulf Coastal Plain. Designated a solesource aquifer in the San Antonio and Austin, Tex., regions by the U.S. Environmental Protection Agency (2006), the aquifer is critical to farming and ranching economies west of San Antonio and recreational economies northeast of the city. The headwaters of the Comal and San Marcos Rivers consist of groundwater discharged from the Comal and San Marcos Springs, respectively, that issue from the Edwards aquifer; these springs support five federally listed and three candidate endangered species (Edwards Aquifer Research and Data Center, 2010). Withdrawals from the Edwards aquifer meet the water-supply needs of more than 2 million people in the San Antonio region. In 2003, water use from the Edwards aquifer in Atascosa, Bexar, Comal, Hays, Kinney, Medina, Travis, and Uvalde Counties was estimated to be 460.7 million cubic meters $\left(\mathrm{m}^{3}\right)$ (Texas Water Development Board, 2008). Municipal withdrawals accounted for about 70 percent, and irrigation accounts for 27 percent; the remaining 3 percent included manufacturing, steam electric power generation, mining, and livestock (Texas Water Development Board, 2008). Bexar and Uvalde Counties are the largest producers of groundwater from the Edwards aquifer in south-central Texas; use in Bexar County is mostly municipal, and use in Uvalde County is mostly irrigation (Texas Water Development Board, 2008).

Crandall and others (2009, p. 1) explained, "sustainability of groundwater quality for public supply requires monitoring and understanding of the mechanisms controlling the vulnerability of public-supply wells to contamination." Burow and others (2008, p. 2) wrote,

Aquifer and public-supply-well vulnerability to contamination is a function of the intrinsic conditions of an aquifer, such as depth to water, flow-system confinement, recharge rate, horizontal and vertical hydraulic conductivity, porosity, pumping rate, and geochemical conditions (Focazio and others, 2002). Public-supply-well vulnerability is determined by assessing aquifer susceptibility and potential contaminant sources overlying or within the area contributing recharge to the well (Franke and others, 1998; Focazio and others, 2002). The word 'contaminant' is defined as any natural or anthropogenic chemical or physical property of the groundwater resource in question that could threaten human health, interfere with water-treatment practices (Focazio and others, 2002), or cause other problems.

The definition of "contaminant" is the same in this report. In 2001, the U.S. Geological Survey (USGS) National Water-Quality Assessment (NAWQA) Program, as part of a broad program to provide an understanding of water-quality conditions across the United States, began an intensive study to assess the vulnerability of public-supply wells to contamination from a variety of compounds (Eberts and others, 2005). As part of the NAWQA Program, the Transport of Anthropogenic and Natural Contaminants (TANC) study is focusing on the transport and chemical processes of selected naturally occurring and anthropogenic contaminants from urban and agricultural sources within that part of the groundwater system contributing water to public-supply wells. Eberts and others $(2005$, p. 1) wrote, "because subsurface processes and management practices differ among aquifers and public-water systems, public-supply wells in different parts of the Nation are not equally vulnerable to contamination, even where 


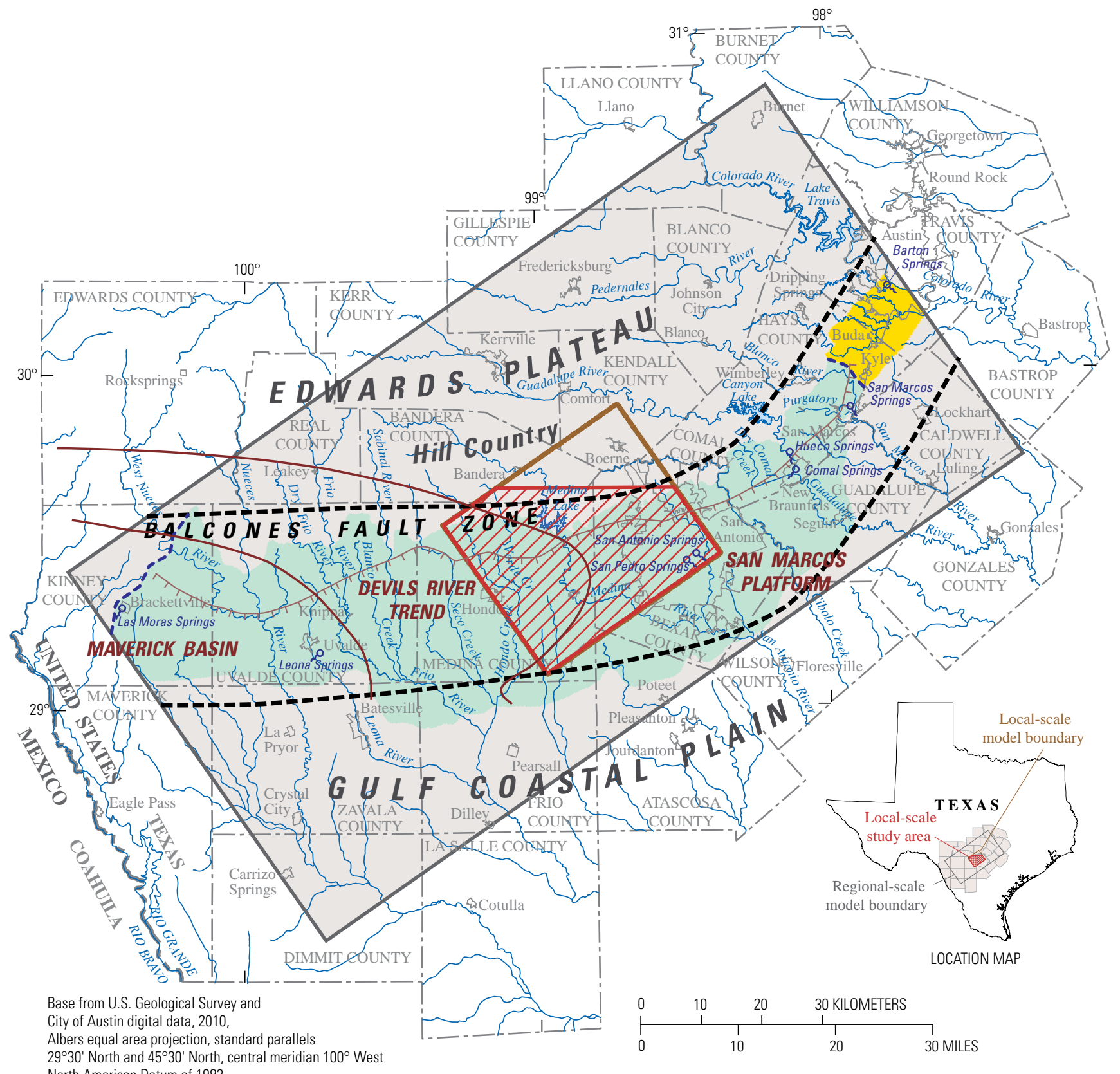

EXPLANATION
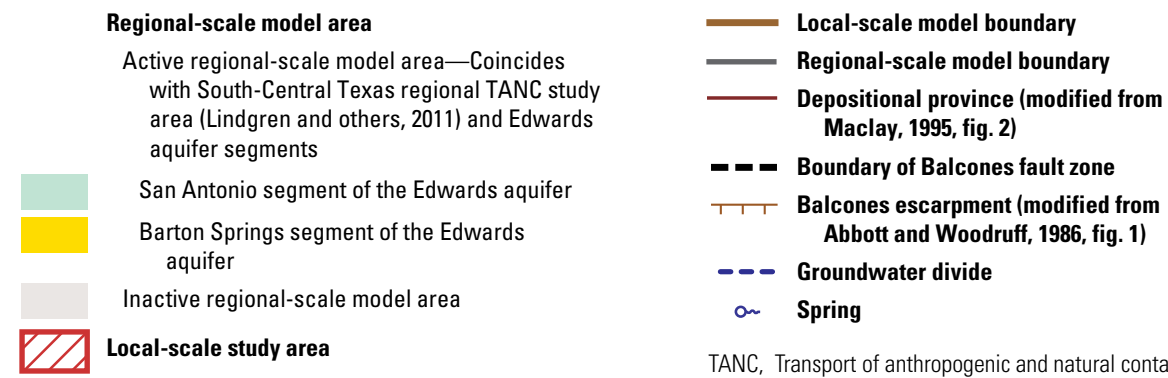

TANC, Transport of anthropogenic and natural contaminants

Figure 1. Location of regional-scale and local-scale model areas, Edwards aquifer segments, and physiographic regions, San Antonio region, Texas. 
similar contaminant sources exist.” The TANC study—which is being conducted at multiple locations across the Nation, including south-central Texas (Lindgren and others, 2011) - is identifying and comparing these important differences in a complementary set of aquifer systems, urban settings, and public-water systems based on data that were collected and analyzed by using consistent methods. To perform this analysis across multiple scales, the TANC study design called for regional-scale and local-scale study areas and the development of nested numerical groundwater-flow models. The northern part of Bexar County in the San Antonio region is one of the selected sites for a local-scale comprehensive study, which is the subject of this report. Data collection for the local-scale study was completed in February 2010. Two regional-scale groundwater-flow models, differing only in their hydraulic conductivity distributions, were developed for the Edwards aquifer in south-central Texas for the regional-scale TANC study and were used to estimate areas contributing recharge to many public-supply wells (Lindgren and others, 2011). A detailed local-scale model within the boundaries of the regional-scale models was then developed to simulate groundwater flow within the area contributing recharge to a selected public-supply well in the local-scale study area.

\section{Purpose and Scope}

The purpose of this report is to present the dominant processes affecting the vulnerability to contamination of a publicsupply well in the Edwards aquifer in the City of San Antonio in northern Bexar County in south-central Texas. This report includes a brief description of the design of the local monitoring well network and methods of data collection and analysis. Groundwater ages and the distribution of selected constituents are used for developing basic interpretations of groundwater recharge and discharge patterns and pathways.

This report documents the construction and calibration of a local-scale groundwater-flow model. The local-scale model incorporates selected hydraulic properties and boundary conditions from previously developed regional-scale models developed for the South-Central Texas regional TANC study (Lindgren and others, 2011) (fig. 2). The results of steady-state simulations of groundwater flow and traveltimes conducted for the local-scale model are also described. The steady-state simulations are not intended to exactly match transient hydrologic conditions and transport characteristics in the karstic Edwards aquifer system but rather are meant to provide insight into the types of processes that are important in a system such as this one. The local-scale model was used to simulate approximate traveltimes and flow paths for potential contaminants and, thereby, address overarching NAWQA TANC objectives to (1) assess the effects of natural factors and human activities on contaminant occurrence in public-supply wells (PSWs), and (2) provide information to managers so they can develop more effective strategies to deal with contamination problems affecting selected PSWs throughout the United States.
This report is intended to serve as a foundation for model synthesis analyses on which results can be compared between this TANC local-scale study area and other TANC study units in Connecticut, California, Nebraska, Florida, and New Mexico. Results of synthesis analyses and descriptions of other TANC study units are not included in this report.

\section{Previous Groundwater-Flow Models}

A number of numerical groundwater-flow models have been constructed for the San Antonio and (or) Barton Springs segments of the Edwards aquifer. Lindgren and others (2009) described and evaluated six regional-scale groundwater-flow models that are published and generally accepted by the water-resources community. Two of the models developed in MODFLOW-2000 (Harbaugh and others, 2000) - the Edwards aquifer ones (Lindgren and others, 2004; Lindgren, 2006) (hereinafter, the "original Edwards aquifer models")-were modified for the South-Central Texas regional TANC study (Lindgren and others, 2011) to simulate groundwater flow in the South-Central Texas regional TANC study area (fig. 2). The original Edwards aquifer models were calibrated for two hydraulic conductivity distributions. A numerical groundwater-flow model (hereinafter, the "conduit-flow Edwards aquifer model") of the karstic Edwards aquifer in south-central Texas was developed for a study conducted during 2000-3 on the basis of a conceptualization emphasizing conduit development and conduit flow (Lindgren and others, 2004). Uncertainties regarding the degree to which conduits pervade the Edwards aquifer and influence groundwater flow, as well as other uncertainties inherent in simulating conduits, raised the question of whether a model based on the conduit-flow conceptualization was the optimum model for the Edwards aquifer. Accordingly, a model with an alternative hydraulic conductivity distribution without conduits was developed in a study conducted during 2004-5 (Lindgren, 2006). The hydraulic conductivity distribution for the Edwards aquifer model without conduits (hereinafter, the "diffuse-flow Edwards aquifer model") is based primarily on a conceptualization in which flow in the aquifer predominantly is through a network of numerous small fractures and openings.

The original Edwards aquifer models (Lindgren and others, 2004; Lindgren, 2006) were modified for the SouthCentral Texas regional TANC study (Lindgren and others, 2011) to a finer discretization, both horizontally and vertically, and updated to include the 2001-3 time period. Two model layers were used to represent the multiple hydrogeologic zones that compose the Edwards aquifer, compared to the one model layer for the original Edwards aquifer models, and the dimensions of the grid cells were reduced by one-half. The rediscretized regional-scale groundwater-flow models calibrated for the South-Central Texas regional TANC study (hereinafter, the "rediscretized regional Edwards aquifer models") cover about 41,920 square kilometers $\left(\mathrm{km}^{2}\right)$ in south-central Texas and consist of 2 layers, 1,400 columns, and 740 rows, with the dimensions of the grid cells being uniformly 201.2 meters (m) 
Stream basin or contributing area

(1) Nueces-West Nueces River Basin

(2) Frio-Dry Frio River Basin

(3) Sabinal River Basin

(4) Area between Sabinal and Medina River Basins (includes Hondo and Seco Creeks)

(5) Medina River Basin

6) Area between Medina River Basin and Cibolo-Dry Comal Creek Basins (includes Salado Creek)

(7) Cibolo and Dry Comal Creek Basins

(8) Guadalupe River Basin

(9) Blanco River Basin (includes Blanco River and Purgatory Creek)

(10) Barton Springs segment contributing area (includes Barton Williamson, Slaughter, Bear, and Onion Creeks)

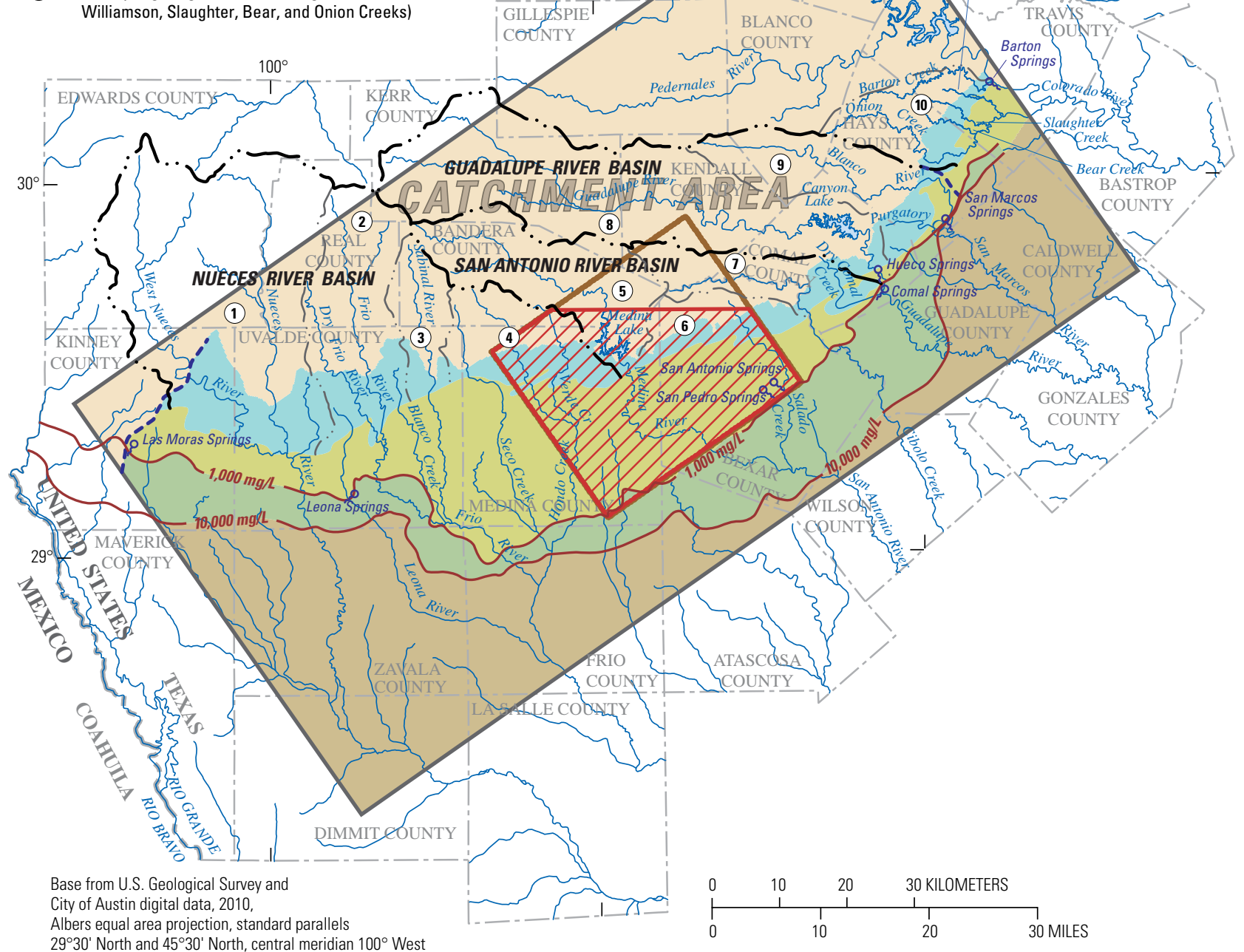

$29^{\circ} 30^{\prime}$ North and $45^{\circ} 30^{\prime}$ North, central meridian $100^{\circ}$ West North American Datum of 1983

\section{Regional-scale model area}

Active regional-scale model area-Coincides with South-Central Texas regional TANC study area (Lindgren and others, 2011) and Edwards aquifer segments

Recharge zone (outcrop) of the Edwards aquifer (modified from Puente, 1978)

Freshwater zone of the Edwards aquifer Freshwater/saline-water transition zone of the Edwards aquifer

\section{EXPLANATION}

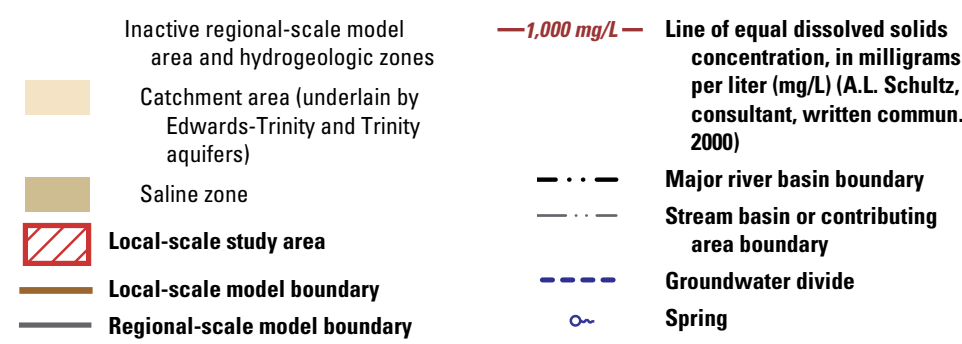

TANC, Transport of anthropogenic and natural contaminants

Figure 2. Location of regional-scale and local-scale model areas, hydrogeologic zones, and catchment area (upper parts of stream basins that contribute recharge) of the Edwards aquifer, San Antonio region, Texas. 
along rows and columns (Lindgren and others, 2011). The rediscretized regional Edwards aquifer models (Lindgren and others, 2011) were calibrated by using two different hydraulic conductivity distributions, based on conduit flow or diffuse flow, as was done for the original Edwards aquifer models (Lindgren and others, 2004; Lindgren, 2006). The two rediscretized regional Edwards aquifer models are hereinafter referred to as the "conduit-flow rediscretized regional Edwards aquifer model" and the "diffuse-flow rediscretized regional Edwards aquifer model" when they are discussed separately.

The initial boundary conditions and hydraulic properties used in the rediscretized regional Edwards aquifer models (Lindgren and others, 2011) were the same as those used in the original Edwards aquifer models (Lindgren and others, 2004; Lindgren, 2006) but were adjusted to conform to the smaller grid size in the rediscretized regional Edwards aquifer models. The rediscretized regional Edwards aquifer models (both the conduit-flow and diffuse-flow models) were calibrated for steady-state and transient conditions. Average stresses (recharge and pumpage) during 2001, a representative year for the recent time period (2000-3), were used to simulate steady-state conditions. The transient simulation period for the rediscretized regional Edwards aquifer models was 2000-3, with 48 monthly stress periods. The steady-state and transient simulations for the rediscretized regional Edwards aquifer models were calibrated to $2000-3$ conditions, primarily by using a trial-and-error approach, by varying the simulated recharge rates and hydraulic conductivities. The rediscretized regional Edwards aquifer models developed for the SouthCentral Texas regional TANC study are discussed in Lindgren and others (2011).

\section{Description of Study Area}

In 2006, a PSW in San Antonio, Tex., was selected out of 39 wells that were sampled for the NAWQA Program's Source Water-Quality Assessment program and the NAWQA TANC study in the San Antonio region as the focus of a study of processes influencing movement of contaminants between recharge areas and the PSW. Water samples from this selected public-supply well (hereinafter, the "selected PSW") were initially collected and analyzed in 2004 and 2005 for a wide suite of chemical and physical constituents. Results from the analyses showed the presence of multiple contaminants, but concentrations were below drinking-water standards. The most frequently detected chemicals were the pesticide compounds atrazine, deethylatrazine, simazine, and prometon and the volatile organic compounds chloroform and tetrachloroethylene (PCE). The construction and operational practices of the selected PSW are representative of many PSWs that use the Edwards aquifer for supplying the water for the population of San Antonio, which includes Bexar and Comal Counties. In addition, the water purveyor was willing to make available the selected PSW, which is one of their primary community watersystem PSWs. The combination of the detected constituents, cooperation of the city utility, and typical well construction and operational practices prompted the focus on the selected PSW for the local-scale study.

The local-scale study area, the focus of this report, is in Bexar and Medina Counties in south-central Texas and includes the northwestern part of San Antonio (fig. 1). The local-scale study area includes about $2,844 \mathrm{~km}^{2}$ and is underlain by the Edwards aquifer. The Edwards aquifer underlies much of south-central Texas and provides the water supply for more than 2 million people in the San Antonio region. The local-scale study area is nested within the regional-scale study area, which coincides with the regional-scale model area (Lindgren and others, 2011). The local-scale study area includes the active area of the local-scale model and a small part of the catchment area north of the Edwards aquifer recharge zone (fig. 3). The local-scale study area and localscale model boundary were determined by using the rediscretized regional Edwards aquifer models, developed for the regional-scale TANC study (Lindgren and others, 2011), to identify the areas contributing recharge (ACR) of the selected PSW. The local-scale study area boundaries on the west and east were placed a short distance beyond the farthest western and eastern extents of the ACR of the selected PSW, as simulated by the rediscretized regional Edwards aquifer models, to minimize any potential effects of the model boundaries on the ACR simulated by the local-scale model. The southern boundary of the local-scale study area approximates the 1,000-milligrams-per-liter (mg/L) dissolved solids concentration line (updip boundary of the freshwater/saline-water transition zone) (fig. 2). The northern boundary of the local-scale study area ranges from less than 1 mile to about 10 miles north of the updip limit of the Edwards aquifer recharge zone (fig. 3).

MODFLOW requires a rectangular area for the model grid (fig. 4). The extent of the local-scale study area is less than the extent of the local-scale model area because only part of the inactive local-scale model area (catchment area) is included in the local-scale study area. The active and inactive parts of the local-scale model area are shown in figure 4 . The local-scale model area (fig. 4) is oriented with the regional direction of groundwater flow and the major faults in the Balcones fault zone to minimize error in cell-to-cell and boundary flows.

The local-scale study area includes part of the Edwards Plateau (southern margin of the plateau referred to as the "Hill Country") and the comparatively flat Gulf Coastal Plain, which are separated by the Balcones escarpment (fig. 1). The Edwards aquifer is part of an aquifer system developed in thick and regionally extensive Lower Cretaceous-age carbonates that underlie large parts of Texas (Barker and Ardis, 1996, fig. 2). The Edwards aquifer is unconfined adjacent to and in the outcrop (recharge zone), where recharge occurs (fig. 2) (Puente, 1978). The water table is at depths generally greater than $30 \mathrm{~m}$ below the streambeds (Hovorka and others, 2004). The Edwards aquifer is confined in downdip parts of the Balcones fault zone, including the freshwater zone and the freshwater/saline-water transition zone (fig. 2). Groundwater flow 


\section{EXPLANATION}
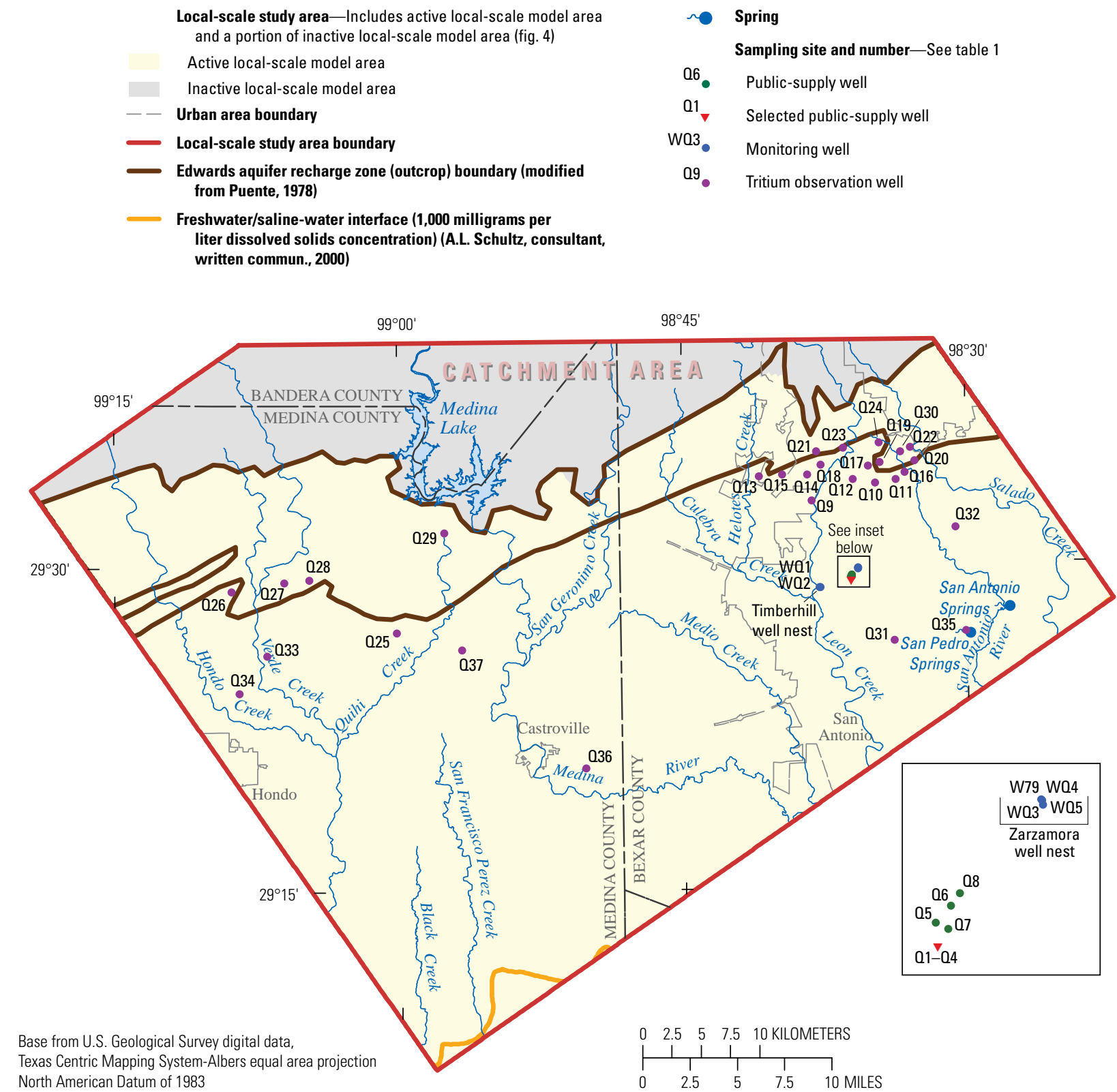

Figure 3. Local-scale study area and locations of public-supply wells, monitoring wells, and tritium observation wells for the localscale model, San Antonio region, Texas.

and aquifer properties are appreciably affected by the presence of faults and karst dissolution features. Karst features such as sinkholes, solution enlargement along fractures and bedding planes, caves, and springs are prevalent in the local-scale study area. In the outcrop (Edwards aquifer recharge zone), karst landforms include shallow, internally drained depressions; depressions of holes in creek bottoms; and small upland features such as sinkholes and solution-enlarged fractures (Hovorka and others, 2004). In addition, more than 400 caves have been inventoried in the Edwards aquifer outcrop (Veni, 1988; Elliott and Veni, 1994; Clark and Morris, 2011). The Edwards aquifer is recharged predominantly through seepage from surface streams that flow onto the outcrop of the aquifer. Discharge from the aquifer is primarily from withdrawals by wells and springflow.

The climate in the local-scale study area is subtropical humid (Larkin and Bomar, 1983). Average annual rainfall is 78.7 centimeters per year $(\mathrm{cm} / \mathrm{yr})$ at San Antonio. Months- to years-long droughts that strain water supplies and produce widespread crop failure commonly are followed by wet periods that include torrential rains and flash floods (Bomar, 1994). A severe drought occurred during 1950-56, when rainfall at San Antonio was less than the 30-year (1961-90) normal $(78.7 \mathrm{~cm} / \mathrm{yr})$ during each year of this 7 -year span. 


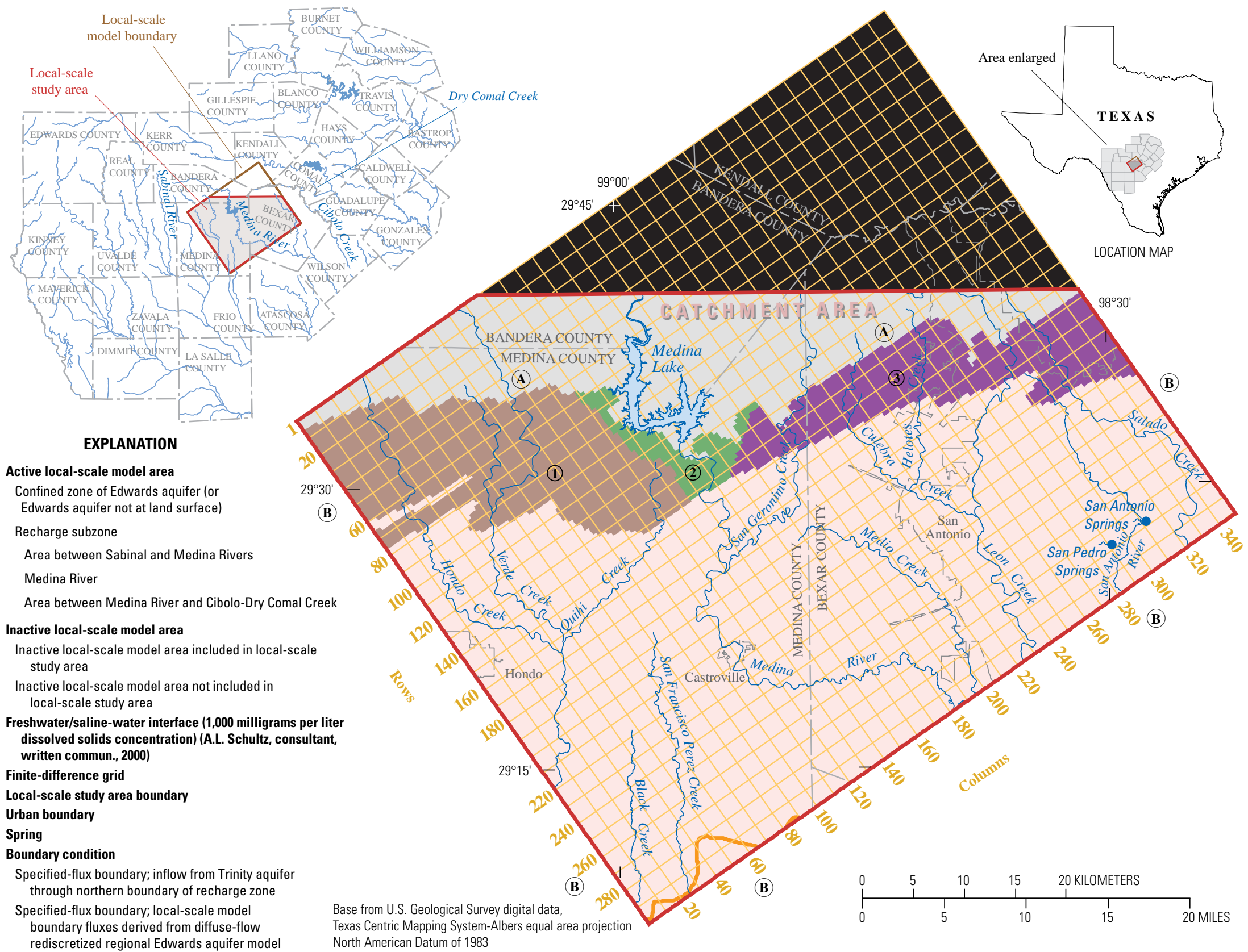

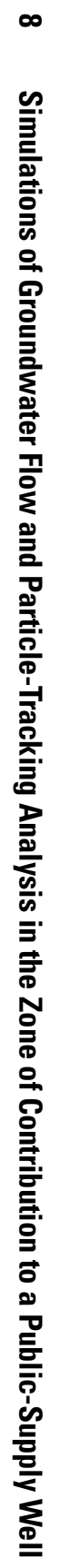

Figure 4. Model grid, boundary conditions, and simulated subzones of the recharge zone of the Edwards aquifer for the local-scale model, San Antonio region, Texas. 
During 5 of those years, rainfall was two-thirds or less of the 30 -year normal. Storms can produce rapid runoff and recharge to the Edwards aquifer. During the 1970s and 1990s, rainfall in the region was generally greater than the 30 -year normal rainfall; however, dry years (such as 1975 and 1996) periodically resulted in declines of water-level altitudes in the Edwards aquifer and below-average springflow.

The local-scale study area encompasses the upper parts of the Nueces and San Antonio River Basins (fig. 2). Surface water and groundwater in south-central Texas are uniquely interrelated. Fahlquist and Ardis (2004, p. 3) noted,

Springs and seeps discharge along impermeable zones of the Trinity aquifer in the deeply incised stream channels of the Edwards Plateau. These springs provide base flow to streams that flow southward and eastward from the plateau. As they flow across the highly permeable, fractured and faulted carbonate rocks of the Edwards aquifer in the Balcones fault zone, most streams lose all of their base flow as recharge to the Edwards aquifer.

Two large springs (San Pedro and San Antonio) issue from the confined part of the Edwards aquifer in the localscale study area (fig. 3).

Land use in the local-scale study area correlates with physiography. The rugged, thin-soiled terrain of the Edwards Plateau is largely undeveloped, and rangeland predominates. The flatter, thicker-soiled terrain of the Gulf Coastal Plain is better suited to growing crops - primarily hay, sorghum, wheat, corn, and oats. In 2001, land use (Homer and others, 2001) in the local-scale study area, excluding the catchment area (north of the recharge zone), was characterized by 35.5 percent rangeland, 27.9 percent forest, 23.1 percent urban, and 11.8 percent agriculture; the remainder was water, wetlands, or barren land. San Antonio, the principal urban area, includes much of Bexar County (fig. 1) and the southeastern part of the local-scale study area (fig. 3).

\section{Methods of Investigation}

The methods used for this study were consistent with the objectives of the nation-wide NAWQA/TANC study, which included the use of similar methods in all six local-scale study area investigations. The uses of similar methods of waterquality data collection and analyses, MODFLOW (Harbaugh and others, 2000) to simulate groundwater flow, and MODPATH (Pollock, 1994) to simulate the pathlines of water particles in groundwater provide consistency and comparability for the TANC local-scale studies (Eberts and others, 2005).

\section{Data Collection and Analysis}

A total of six wells were installed during 2007-8 in two well nests (with four wells in one well nest and two wells in the other nest) oriented along one of the general directions of groundwater flow to the selected PSW based on flow directions indicated by the regional-scale model (Lindgren and others, 2011). The well nests were Zarzamora (four wells) and Timberhill (two wells) (fig. 3, table 1 at end of report). The Zarzamora well nest included one well screened in the overburden overlying the Edwards aquifer (Zarzamora_OVB; W79) and three wells screened in the Edwards aquifer at shallow (Zarzamora_SED; WQ3), intermediate (Zarzamora_IED; WQ4), and deep (Zarzamora_DED; WQ5) depths (table 1). The Timberhill well nest included two wells screened in the Edwards aquifer at intermediate (Timberhill_IED; WQ1) and deep (Timberhill_DED; WQ2) depths (table 1).

Water-level altitudes were measured in all monitoring and observation wells during water-quality sampling, and water-level recorders were installed in six monitoring wells (Zarzamora and Timberhill site wells) to provide water-level altitude data that were used to calibrate the groundwater-flow model (table 2 at end of report). Groundwater altitudes were recorded hourly from January 2008 through February 2010.

During calibration of the groundwater-flow model, measured monthly mean groundwater altitudes (calculated from hourly water-level altitudes measured by water-level recorders) were compared to simulated monthly groundwater altitudes. Hydrographs depicting mean daily water levels from September 1, 2007, through March 1, 2010, for the Zarzamora and Timberhill monitoring wells are shown in figure 5. Waterlevel altitudes collected for this study are summarized in table 2, and all well locations are shown on figure 6 .

Groundwater samples analyzed for tritium concentrations were collected during 2007-8 from the selected PSW (WZ4), from four additional PSWs (WZ2, WZ3, WZ5, and WZ6), and from six monitoring wells (Timberhill and Zarzamora well nests) (fig. 3, table 1). Groundwater samples included wellhead samples from the PSWs (Q1 [the selected PSW], Q5, Q6, Q7, and Q8) and depth-dependent samples from the selected PSW (Q2, Q3, and Q4) and the monitoring wells (WQ1, WQ2, WQ3, WQ4, and WQ5) (fig. 3, table 1). Geophysical and flowmeter logs were collected from the selected PSW (Q1) to determine zones of contribution to the wellbore prior to sampling. For flow measurements and depth-dependent water sample collection, the production pump was removed, and a temporary turbine pump was lowered below the existing water-level depth such that the intake was about a meter above the bottom of the steel casing in the selected PSW, allowing for drawdown and a pumping rate of 2.5-3.2 cubic meters per minute $\left(\mathrm{m}^{3} / \mathrm{min}\right)$. This pump was used to stress the well to simulate production conditions during the pumped flowmeter logging and depth-dependent water sample collection. For comparison purposes, the simulated pumping rate for the selected PSW in the local-scale model, representative of average conditions during the recent time period (2000-10), is $10.5 \mathrm{~m}^{3} / \mathrm{min}$, about three to four times greater than the pumping rate for the temporary turbine pump.

Four pumping conditions were logged with the flowmeter: (1) no pumping in the selected PSW or well field (an operationally rare occurrence referred to as "ambient 1"); (2) no pumping in the selected PSW, but with pumping of 


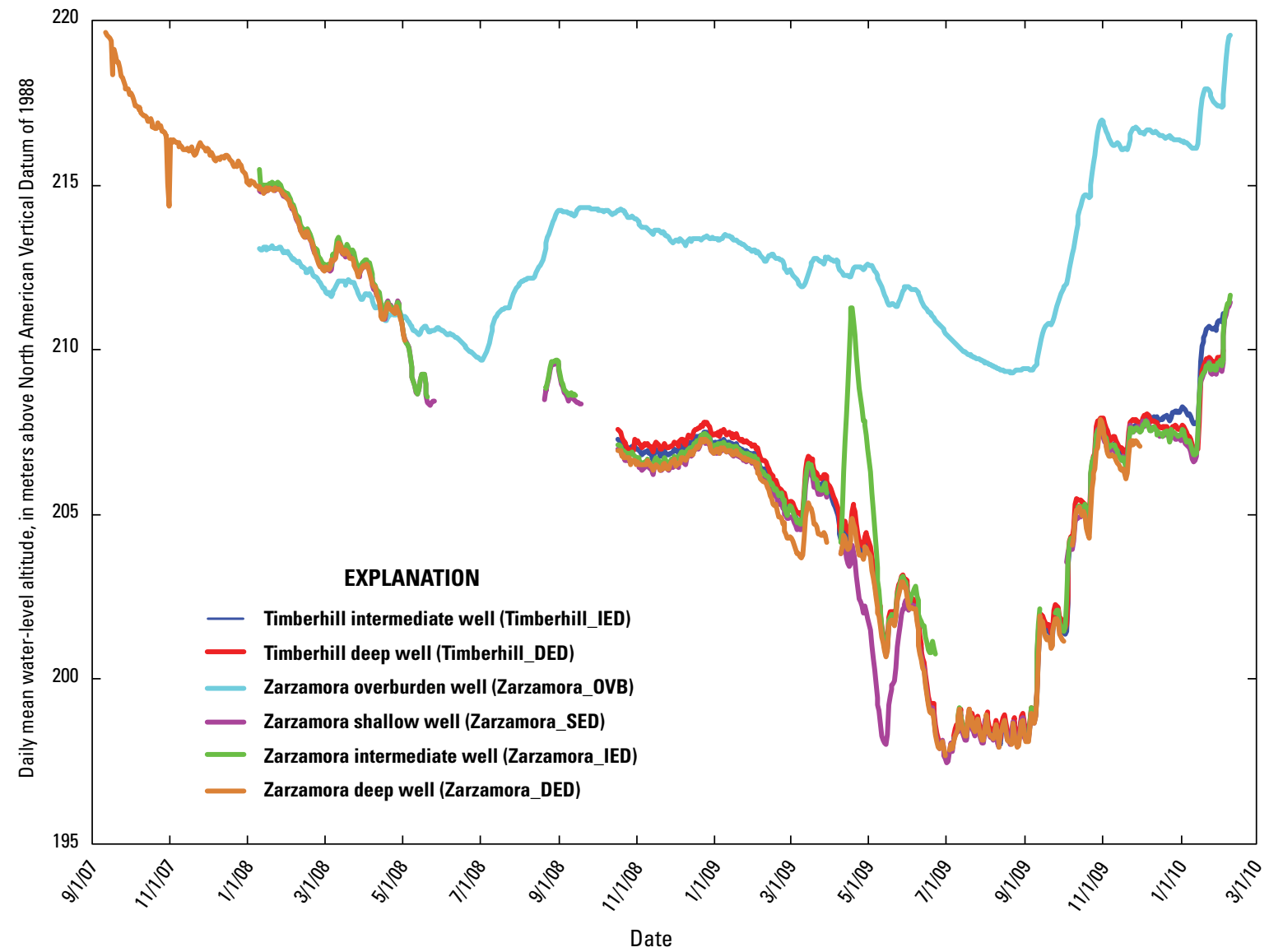

Figure 5. Daily mean water-level altitudes from continuous water-level recorders in monitoring wells in the local-scale study area, September 12, 2007, to February 9, 2010, San Antonio region, Texas.

nearby well(s) in the well field ("ambient 2"); (3) pumping of the selected PSW, with no pumping of additional wells in the well field ("moderate"); (4) pumping of the selected PSW, with pumping of nearby well(s) in the well field ("normal"). "Normal" pumping conditions, with surrounding wells in the well field operating under typical pumping schedules (selected PSW and nearby PSWs in the well field pumping at total discharge rates from approximately 29.4 to $107 \mathrm{~m}^{3} / \mathrm{min}$ ), are likely to be most representative of pumping conditions associated with typical well-field production conditions. However, as noted in the previous paragraph, the pumping rate for the temporary turbine pump used for collecting the depth-dependent water samples was much less than the recent (2000-10) average pumping rate for the selected PSW.

Depths for sampling (selected on the basis of zones of flow within the selected PSW) were (1) shallow (116 m), (2) intermediate $(131 \mathrm{~m})$, and (3) deep $(165 \mathrm{~m})$, which are associated with three different Edwards Group stratigraphic units, specifically, (1) the cyclic and marine members (undivided), (2) the leached and collapsed members, and (3) the Kirschberg evaporite member, respectively. The measured tritium concentrations for the selected PSW (one wellhead and three depth-dependent samples) for "normal" well-field pumping conditions, five of the six Timberhill and Zarzamora monitoring wells (excluding well Zarzamora_OVB), and four PSWs (WZ2, WZ3, WZ5, and WZ6) were used to calibrate the local-scale model. The measured tritium concentration for Zarzamora monitoring well Zarzamora_OVB was anomalous and thus not used for the local-scale model calibration.

\section{Development and Application of Groundwater- Flow and Particle-Tracking Models}

A local-scale, steady-state, three-dimensional numerical groundwater-flow model was developed and used in this study to evaluate the movement of water and solutes from recharge areas to the selected PSW. The local-scale model was nested within the rediscretized regional Edwards aquifer models used for the TANC regional analysis (Lindgren and others, 2011). The local-scale model was constructed and run by using the USGS finite-difference groundwater flow FORTRAN computer-model code MODFLOW-2000 (Harbaugh and others, 2000). Particle pathlines and traveltimes associated with simulated particles of water that discharge to wells were determined by using MODPATH version 5.0 - the USGS particletracking software (Pollock, 1994). Dispersion, diffusion, 
EXPLANATION

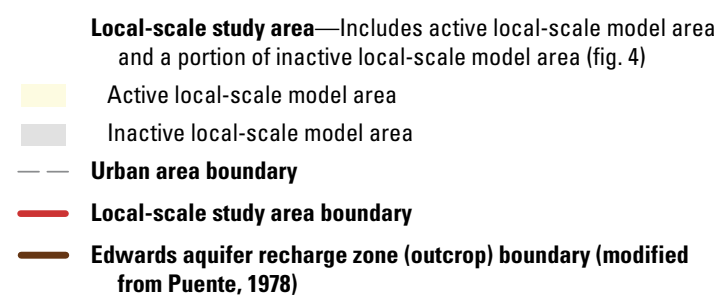

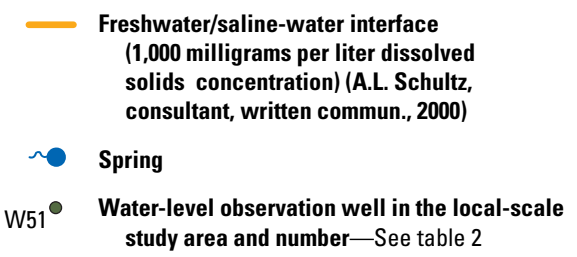

study area and number-See table 2

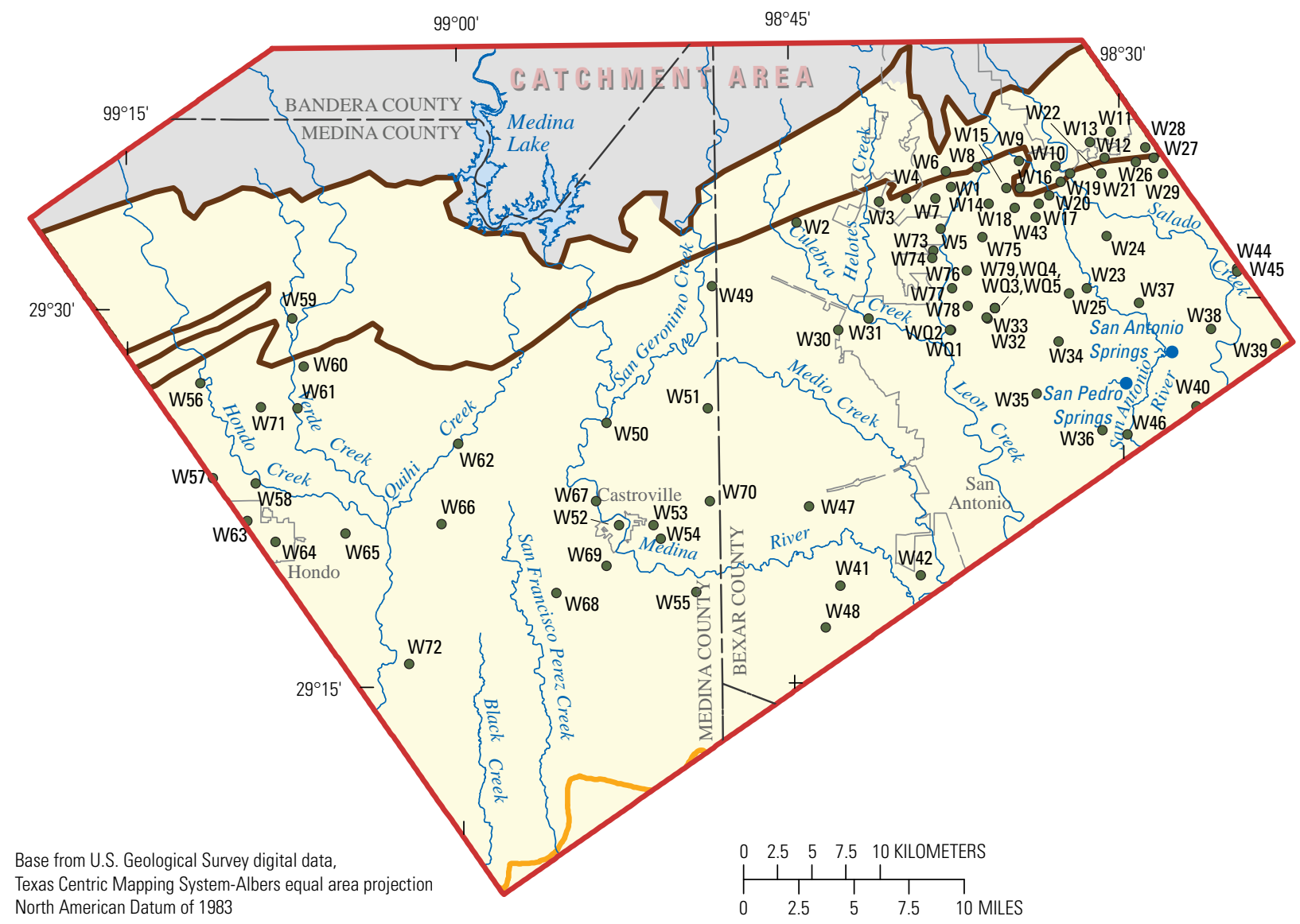

Figure 6. Local-scale study area and locations of observation wells used to monitor water-level altitudes for inclusion in the localscale model, San Antonio region, Texas.

adsorption, retardation, degradation, or any other transport process affecting the concentrations of contaminant constituents are not included in the MODPATH simulation for determining traveltimes of water. The parameter estimation code PEST (acronym for Parameter ESTimation) was used to estimate horizontal and vertical hydraulic conductivities, fault and drain hydraulic conductances, and porosity values by using an automated nonlinear-estimation technique (Doherty, 2005). PEST is a parameter-estimation program that can be used with any model that reads its input data from one or a number of American Standard Code for Information Interchange (ASCII) (text) input files and writes the outcomes of its calculations to one or more ASCII output files (Doherty, 2005). This program allowed for concentrations of the environmental tracer tritium to be used in addition to water-level altitudes and spring discharges in estimating the parameters for MODFLOW and MODPATH. Groundwater flow and particle-tracking simulations were refined in concert to obtain the best match for simulated water-level altitudes, spring discharges, and groundwater age-tracer (tritium) concentrations and to ensure that hydraulic parameter estimates were reasonable.

An important part of the local-scale model development was the incorporation of the complex hydrogeology of the Edwards aquifer into the numerical framework of the model. The local-scale model grid has a finer vertical discretization than do previous regional Edwards aquifer models (Lindgren 
and others, 2004; Lindgren, 2006) and incorporates refined parameter zones corresponding with multiple (10) hydrogeologic units representing the Edwards aquifer. In the Edwards aquifer, high matrix porosity and permeability likely are overshadowed by high permeability developed in structurally influenced karstic conduit systems that transmit water into, through, and out of the aquifer system. The complexity of the aquifer system in the local-scale study area is further increased by numerous faults with varying vertical displacements. The extensive faulting results in the juxtaposition of hydrogeologic units (HGUs) with differing hydraulic properties and has appreciable effects on groundwater flow in the Edwards aquifer. The local-scale model simulations use the MODFLOW Hydrogeologic-Unit Flow Package (Anderman and Hill, 2000) and include two HGUs with high hydraulic conductivities (one or more orders of magnitude higher than for the other simulated hydrogeologic units) that are intended to simulate fast flow paths attributable to karst features. The two "conduit" hydrogeologic units of the Edwards aquifer represent the lower $8 \mathrm{~m}$ of the leached and collapsed members and the Kirschberg evaporite member of the Edwards Group. The MODFLOW Horizontal-Flow Barrier Package (Harbaugh and others, 2000) was used to simulate faults in the local-scale model. The assumption was made that the degree to which a fault acts as a barrier to groundwater flow is proportional to the fault displacement. Steady-state simulation, used for the local-scale model, has many applications in hydrologic investigations. It is used to analyze the natural (predevelopment) flow system, as well as any new equilibrium conditions that have been attained during the course of development (Franke and others, 1984, p. 15). Large temporal variations in Edwards aquifer groundwater withdrawals (fig. 7A) and groundwater recharge amounts (fig. 7B) are common, resulting in large changes in water-level altitudes. During periods of drought, water-level altitudes decline but recover rapidly in response to recharge. Most of the groundwater used for public supply is withdrawn near San Antonio, where water-level altitudes in well W38 (Bexar County index well, J-17) (fig. 6) have varied between a low in 1956 of $186.7 \mathrm{~m}$ above the North American Vertical Datum of 1988 (NAVD 88) to a high in 1992 of $214.4 \mathrm{~m}$ above NAVD 88 (Hamilton and others, 2003). Although recurring droughts and floods have caused appreciable short-term fluctuations in water-level altitudes, long-term hydrographs (about 80 years) indicate no net decline (or rise) of water-level altitudes in the San Antonio region (fig. 8A).

Average stresses (recharge and pumpage) during 2001 were used to simulate steady-state conditions for the localscale model. The year 2001 was chosen to represent average, equilibrium (steady-state) hydrologic conditions because it coincides with the steady-state simulation period for the diffuse-flow rediscretized regional Edwards aquifer model (Lindgren and others, 2011), which was used to establish boundary conditions for the local-scale model. In addition, the year 2001 is representative of average, equilibrium (steady-state) hydrologic conditions during a recent time period (2000-10). The time period 2000-10 includes (1) a typical range of recent groundwater withdrawal rates in the local-scale model area and (2) the period of measurement for water-level altitudes and tritium concentrations used to calibrate the local-scale model. Water-level altitudes used for comparison to model output are based on mean water-level altitudes measured in wells during 2001 and 2007-10. Tritium concentrations used in the local-scale model calibration were derived from water samples collected during 2007-8. Groundwater withdrawals by San Antonio Water System (SAWS) during 2001 were 219.8 million $\mathrm{m}^{3}$, compared to mean annual groundwater withdrawals during 1969-2009 of 200.4 million $\mathrm{m}^{3}$ (San Antonio Water System, 2008; Scott Okland, San Antonio Water System, written commun., 2010). The mean annual groundwater withdrawals by SAWS during 1980-2009, a time period with groundwater withdrawals generally between about 175 and 225 million $\mathrm{m}^{3}$ (fig. 7A) and more representative of recent groundwater withdrawals, were 217.9 million $\mathrm{m}^{3}$. Mean annual groundwater withdrawals by SAWS during 2000-9 were 222.5 million $\mathrm{m}^{3}$, similar to the groundwater withdrawals during 2001 (219.8 million $\mathrm{m}^{3}$ ) (San Antonio Water System, 2008; Scott Okland, San Antonio Water System, written commun., 2010).

Rainfall at San Antonio during 2001 was $93.27 \mathrm{~cm}$, somewhat higher than the mean annual rainfall during 2000-10 of $81.84 \mathrm{~cm}$ and the 30-year normal (1971-2000) rainfall of $83.62 \mathrm{~cm}$ (National Oceanic and Atmospheric Administration, National Climatic Data Center, 2002). Mean annual rainfall at San Antonio during 1969-2009 was $82.89 \mathrm{~cm}$, and during 1980-2009 it was $80.81 \mathrm{~cm}$. The estimated recharge to the Edwards aquifer during 2001 for the three recharge subzones (referred to as "stream basin or contributing areas" in figure 2) in the local-scale study area was 389.3 million $\mathrm{m}^{3}$ (fig. 7B), compared to the mean annual recharge during 2000-9 of 413.5 million $\mathrm{m}^{3}$ (Edwards Aquifer Authority, 2009). The mean annual recharge during 2007-9, the time period for some water-level measurement calibration targets and for tritium concentration calibration targets associated with short (less than 3 years) traveltimes, was 482.5 million $\mathrm{m}^{3}$ (Edwards Aquifer Authority, 2009). The mean annual recharge during 1969-2009 was 386.3 million $\mathrm{m}^{3}$, and during 1980-2009 was 378.1 million $\mathrm{m}^{3}$ (Edwards Aquifer Authority, 2009; Richard Slattery, U.S. Geological Survey, written commun., 2010). The estimated recharge to the Edwards aquifer for the localscale model steady-state calibration (389.3 million $\mathrm{m}^{3}$ during 2001) might be more representative of long-term (1969-2009; 1980-2009) hydrologic conditions than of recent shorter term (2000-9; 2007-9) hydrologic conditions. However, most of the water-level measurement calibration targets were for 2001 and therefore reflect 2001 hydrologic conditions.

The attainment of equilibrium, steady-state conditions during $2000-10$ is indicated by stable average water-level altitudes in wells in or near the zone of contribution (ZOC) of the selected PSW for the time period, with no apparent longterm increases or decreases in water-level altitudes other than seasonal variations and responses to variations in groundwater 

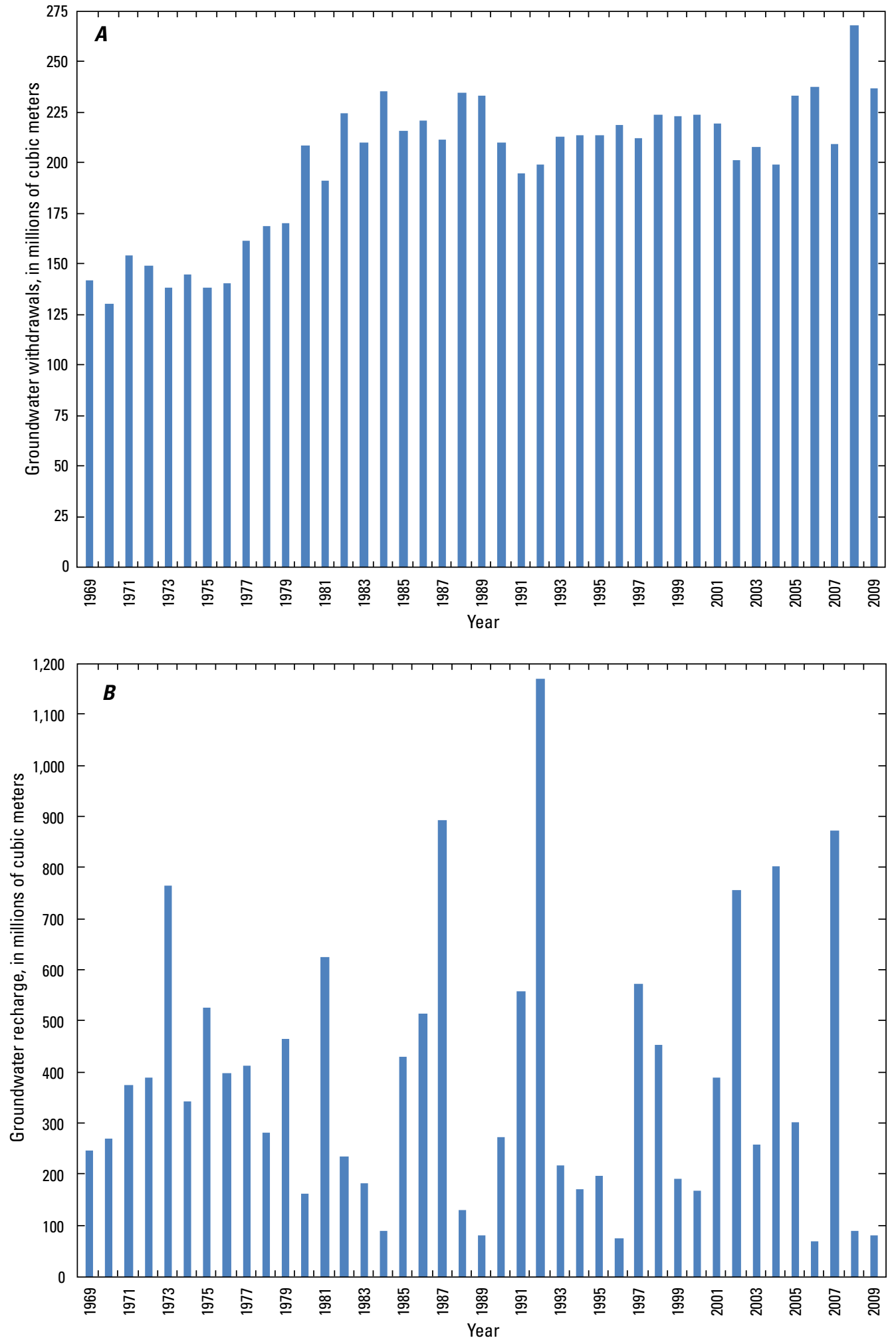

Figure 7. A, annual groundwater withdrawals for San Antonio Water System wells, and $B$, estimated annual groundwater recharge to the Edwards aquifer in the local-scale study area, 1969-2009, San Antonio region, Texas. 

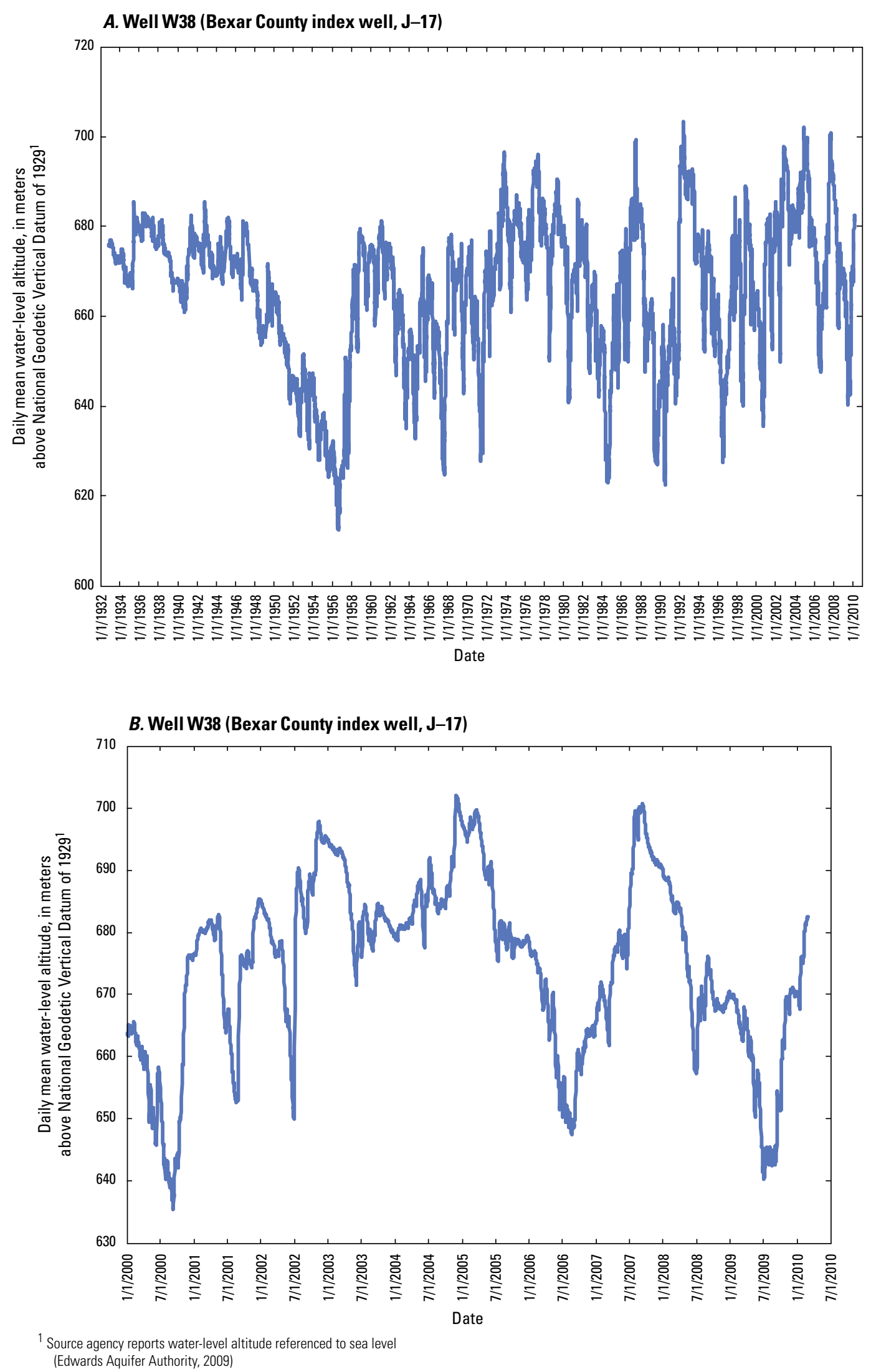

Figure 8. Measured water-level altitudes in well W38 (Bexar County index well, J-17) for $A$, November 12, 1932, to February 28, 2010, and $B$, January 1, 2000, to February 28, 2010, San Antonio region, Texas. 
recharge (fig. 9). Measured water-level altitudes from July 2000 to July 2009 in well W32 indicate an overall decline of about $8.0 \mathrm{~m}$, but the pattern of decline is interrupted by higher water-level altitudes during 2002, 2004, and 2007, which were periods of high groundwater recharge (figs. 7B and 9A). For wells W25 and W4, the measured water-level altitudes in July 2009 are about the same as in July 2000 (figs. 9B and $9 \mathrm{C}$, respectively). An overall increasing or decreasing pattern in water-level altitudes in the Edwards aquifer is also lacking in other parts of the local-scale model area during 2000-10, as indicated by the hydrograph for well W38 (Bexar County index well, J-17), southeast of the selected PSW (figs. 6 and $8 \mathrm{~B})$. For the three wells in or near the $\mathrm{ZOC}$ of the selected PSW, the measured water-level altitudes during 2001-the time period corresponding with the hydrologic conditions used in the local-scale steady-state model calibration - are similar to the mean water-level altitudes for the 2000-10 time period (fig. 9). The mean measured 2001 water level in well W32 was $0.8 \mathrm{~m}$ higher than the mean measured water level for 2000-10, whereas the mean measured 2001 water-level altitudes in wells W25 and W4 were 0.1 and $0.9 \mathrm{~m}$ lower, respectively, than the corresponding mean measured waterlevel altitudes for 2000-10. The similarity in the mean measured water-level altitudes for 2001 and for 2000-10 indicate that the hydrologic conditions simulated in the localscale model steady-state calibration adequately represent the hydrologic conditions for the 2000-10 time period and that the model calibration results are representative for water-level conditions during 2000-10.

A summary of final steady-state traveltimes for each particle reaching the monitoring wells or the selected PSW was obtained from MODPATH and used to describe the distribution of simulated particle ages associated with recharge water reaching the wells. A tritium concentration was assigned to each particle on the basis of the recharge date (from particle ages) and the concentration of tritium in the atmosphere at the time of recharge (minus radioactive decay). Biannual historical concentrations of tritium in the atmosphere were derived from historical concentrations of tritium measured in rainfall at Waco, Tex. (1961-87) and at Vienna, Austria (1961-2006) (International Atomic Energy Agency, 2008). Concentrations of tritium in precipitation (Michel, 1989) peaked in the 1960s and have been generally declining since that time; tritium concentrations were adjusted for radioactive decay to 2009 assuming a half-life of 12.3 years. A flux-weighted average concentration was calculated for each well or particular open interval by multiplying the concentration assigned to each particle by the amount of recharge associated with that particle and summing overall particles reaching a well or particular open interval. The calculated tracer concentration is the result of the mixture at an observation point (well or particular open interval) of all of the concentrations associated with all of the individual simulated particles with pathlines terminating at that observation point. The calculated tracer concentrations derived from simulated flow paths and advective traveltimes computed by MODPATH were compared with measured concentrations.
In addition, the mean of MODPATH-computed advective traveltimes (simulated mean particle age) at an observation point was compared with the apparent groundwater age, which was based on an interpretation of tracer concentrations and an assumed hydrogeologic conceptual model (Musgrove and others, 2011). The apparent groundwater age from tracers can be compared to the mean (or central tendency) of particle ages for each observation point to provide some indication of how plausible both the simulated MODFLOW and geochemical apparent groundwater age results are.

In addition to measured water-level altitudes, the localscale model was calibrated for steady-state conditions by using tritium concentrations measured during a 8-month period from October 2007 to May 2008. The local-scale steady-state model uses average hydrologic conditions during 2001 to approximate the transient hydrologic conditions during the traveltime periods from the source areas (recharge zone) to the wells. The steady-state velocity represents the average condition over the time period that the water particles move from source areas (recharge zone) to the wells, so although the exact conditions are not represented, the average conditions are such as to give reasonable results for the purposes of this study. The steadystate simulations are intended to provide insight into the types of processes that are important in karstic aquifer systems and are not intended to exactly match transient hydrologic conditions and transport characteristics of the karstic Edwards aquifer system.

The simulated mean particle traveltimes from the source area (recharge zone) to the well for wells with measured tritium concentrations used as calibration targets ranged from about 3 to 15 years. Apparent groundwater ages determined for the same wells, derived from tracer concentration data and an assumed hydrogeologic conceptual model (Musgrove and others, 2011), ranged from about 1 to 40 years. Therefore, the entire potential time frame associated with the movement of tritium from the source area (recharge zone) to the wells (about 40 years; 1969-2009) is not necessarily subject to the same hydrologic conditions as those used to calibrate the local-scale steady-state model (average stresses during 2001). However, as discussed previously in this section, recharge and groundwater withdrawals during 2001 were similar to those during 1969-2009, and it is likely the hydrologic conditions from 2001 used to calibrate the local-scale steady-state model were representative of typical 1969-2009 hydrologic conditions. Groundwater withdrawals by SAWS during 2001 were 9.7 percent higher than mean annual groundwater withdrawals during 1969-2009 and only 0.9 percent higher than during 1980-2009, a time period with groundwater withdrawals generally between about 175 and 225 million $\mathrm{m}^{3}$ and more representative of recent groundwater withdrawals (fig. 7A). The estimated recharge to the Edwards aquifer during 2001 in the local-scale study area (fig. 7B) was only 0.8 percent higher than the mean annual recharge during 1969-2009. Also, longterm hydrographs indicate no net decline (or rise) of waterlevel altitudes in the San Antonio region during 1969-2009 (fig. 8A), indicating a lack of persistent hydrologic patterns 


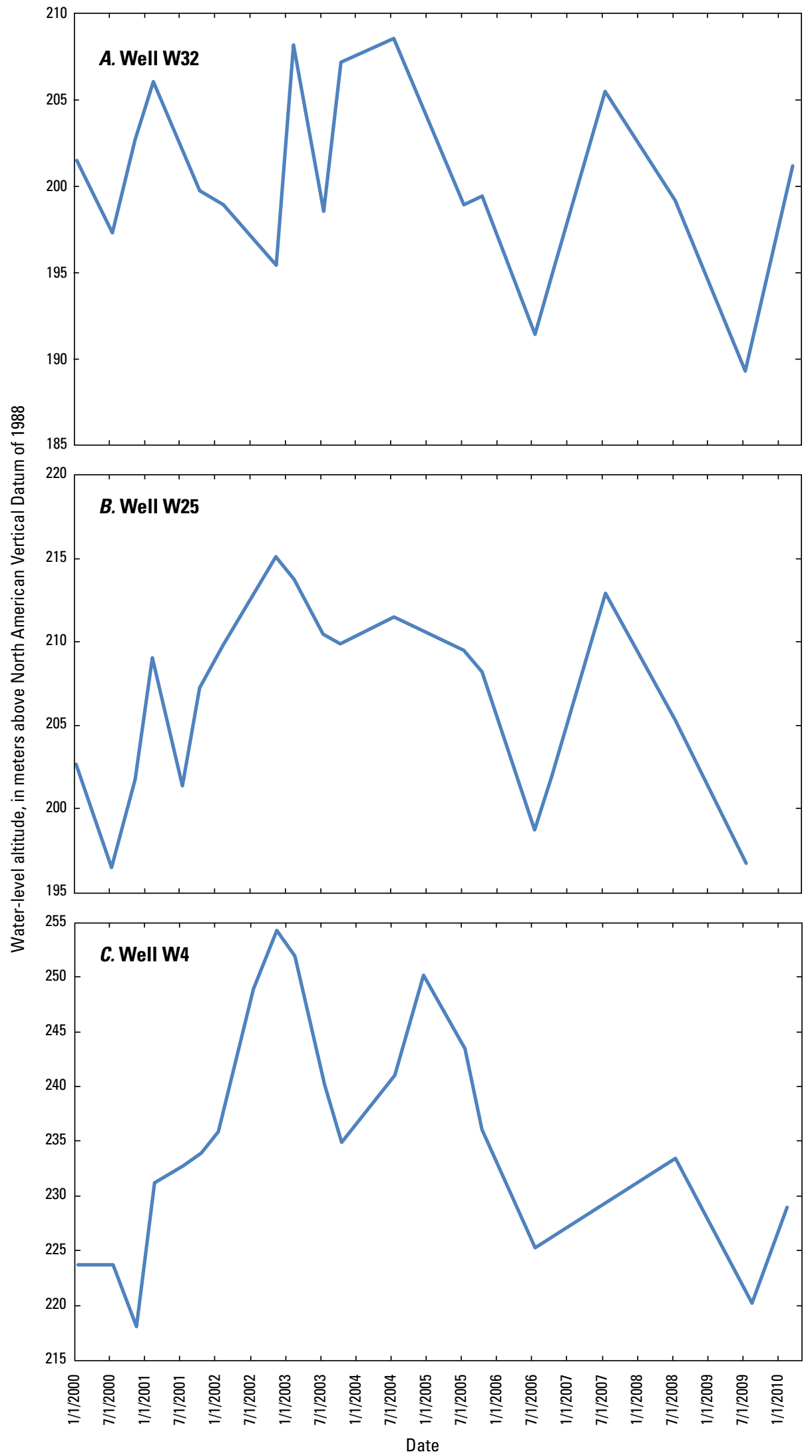

Figure 9. Measured water-level altitudes, San Antonio region, Texas. A, Well W32, January 24, 2000, to March 3, 2010. $B$, Well W25, January 24, 2000, to July 22, 2009. C, Well W4, January 26, 2000, to February 24, 2010. 
during this time period. The increase in annual groundwater withdrawals beginning in about 1980 (fig. 7A) had no apparent effect on equilibrium or average water-level altitudes (fig. 8A). The mean measured 2001 water level in well W38 (Bexar County index well, J-17), located to the southeast of the selected PSW, was $1.7 \mathrm{~m}$ higher than the mean measured water level for 1969-2009 (7.1 percent of the range in measured water-level altitudes during 1969-2009) but was within about $0.03 \mathrm{~m}$ of the mean measured water level during 2000-10. The similarity between the mean measured waterlevel altitudes for 2001 and 2000-10 might indicate that the local-scale model results are more representative of recent hydrologic conditions (2000-10) than they are of hydrologic conditions prior to 2000 . However, a comparison of the magnitudes of groundwater recharge and withdrawal and of mean water-level altitudes for 2001 to those during 2000-10 and 1969-2009 indicate that hydrologic conditions during 2001 adequately represent hydrologic conditions during 2000-10 and 1969-2009 for the purposes of this study. The 2001 hydrologic conditions may be most representative of recent hydrologic conditions (2000-10), but the local-scale model simulation results indicate that young water (less than 5 years) is a major component of the water reaching wells in the ACR of the selected PSW.

The local-scale steady-state model was used to assess the age distribution of water at selected wells and to compute particle traveltimes from the source area (recharge zone) to the wells. The computed traveltimes were then used to compute simulated tritium concentrations, which were compared to measured tritium concentrations. The measured tritium concentration at a well is the result of many factors, including radioactive decay of tritium and transient hydrologic conditions that vary during the traveltime from the source area (recharge zone) to the well. Musgrove and others (2009) reported the results for tritium concentrations measured in samples collected from shallow unconfined water table wells under different hydrologic conditions ranging from relatively wet (1998) to relatively dry (2006). For about half of the samples, the residence time of the water and the accompanying radioactive decay accounts for the differences in measured tritium concentrations between 1998 and 2006. For the other half, however, the differences are likely caused by additional factors, including the timing of recharge to the aquifer and variability in hydrologic conditions (Musgrove and others, 2009). The local-scale steady-state model developed for this study does not account for the potential effects of transient hydrologic conditions on the measured tritium concentrations at a well.

The local-scale model was calibrated for steady-state conditions by using average hydrologic conditions during 2001 and tritium concentrations measured over an 8-month period from October 2007 through May 2008, with a relatively narrow range of measured tritium concentrations (0.51 tritium unit [TU]). An additional 42 tritium concentration values obtained from samples collected during the 1990s from 29 wells and not used in the calibration of the model were compared to computed tritium concentrations derived from the local-scale steady-state model particle-tracking results. A greater range of measured tritium concentrations (3.70 TU) was measured in the 42 tritium concentrations from the 1990s compared to the range of measured tritium concentrations $(0.51 \mathrm{TU})$ measured in the samples collected from October 2007 through May 2008. The agreement between the measured and simulated tritium concentrations for the samples collected during the 1990s was similar to the agreement between the measured and simulated tritium concentrations during 2007-8, indicating that, although the entire range of transient hydrologic conditions are not equally represented in the local-scale steady-state model, the simulated hydrologic conditions and model results are applicable for time periods other than the $2007-8$ period as well.

The use of steady-state simulations, rather than transient simulations, simplified and facilitated the simulation of areas contributing recharge and traveltimes to wells. Reilly and Pollock (1995) showed that when the mean traveltime is much greater than the cyclical nature of the stresses on a system, the steady-state results do not differ appreciably from a transient analysis. This conclusion can be expected to hold true for the steady-state results presented in this report. The simulated steady-state mean traveltimes to wells for this study are generally on the order of years, whereas the recharge and withdrawal stresses on the Edwards aquifer vary seasonally and often daily, and responses in water-level altitudes and springflows are often on the order of days.

The local-scale model was used to simulate the ACR and particle traveltimes from the recharge areas to the well for the selected PSW and selected nearby PSWs and monitoring wells, including nearby PSWs in the same well field. The horizontal and vertical discretization of the model grid of the local-scale model resulted in multiple PSWs being located in the same horizontal (row, column) grid location for two of the three horizontal grid locations encompassing the area of the PSW field that includes the selected PSW. The selected PSW and two other PSWs are located in row 230, column 264 of the model grid and are screened across partially overlapping model layers. The starting particle locations for all three PSWs in row 230, column 264 of the model grid are vertically distributed on each cell face over the open interval of each well. Therefore, for model layers where the open intervals of the wells overlap, the simulated particle traveltimes and the parts of the ACR attributable to the overlapping open intervals (model layers) for each of the wells are the same. However, because the open intervals (model layers) for the wells are not fully coincident, the simulated ACR for the three wells are not exactly the same. The dimensions of the grid cells and number of model layers were determined on the basis of an acceptable balance for particle-tracking purposes and the need to limit the total number of cells in the model. A finer grid discretization that would eliminate the occurrence of multiple PSWs in the same grid cell, or the same horizontal grid location, was not feasible. 


\section{Conceptualization of the Edwards Aquifer $^{1}$}

The conceptualization of the Edwards aquifer includes a description of the geologic and hydrogeologic setting within which the aquifer functions. Sedimentary and crystalline rocks that range in age from Precambrian to Holocene underlie south-central Texas. Four depositional provinces were formed during Lower Cretaceous time: the central Texas platform on the Edwards Plateau, Maverick Basin, Devils River trend, and San Marcos platform (Maclay, 1995) (fig. 1). The Cretaceous strata of south-central Texas regionally include two aquifers: the Edwards aquifer in the Balcones fault zone and the Trinity aquifer in the Hill Country. The Cretaceous rocks composing the Edwards aquifer are laterally and vertically heterogeneous, with eight aquifer subdivisions defined by Maclay and Small (1976, table 1) (fig. 10).

The altitude of the top of the Edwards aquifer in the local-scale study area ranges from about $343 \mathrm{~m}$ above NAVD 88 in the recharge zone in eastern Medina County to about $640 \mathrm{~m}$ below NAVD 88 in the southwestern part of the study area. The aquifer thickness ranges from about $129 \mathrm{~m}$ in and near the recharge zone in Bexar County to about $220 \mathrm{~m}$ in the confined part of the aquifer in the southwestern part of the study area (fig. 11).

\section{Geologic Setting}

The Cretaceous rocks that underlie the local-scale study area include shallow-water facies, which consist of sediments deposited on tidal flats and sabkhas and of subtidal carbonate sediments that accumulated on a carbonate platform. Internal depositional cycle boundaries are overlain by rocks consisting of near-shore and shallow-water sediments in topographically higher parts of the platform grading downdip (seaward) into subtidal carbonate rocks. As facies migrated in response to sea level variation and sediment aggradation, different depositional facies were superimposed vertically. Three depositional provinces were formed in the local-scale study area during Lower Cretaceous time: the central Texas platform on the Edwards Plateau, Devils River trend, and San Marcos platform (Maclay, 1995) (fig. 1). Different depositional facies and different energy conditions associated with carbonate deposition were characteristic in each province.

The Devils River trend, the platform margin rimming the Maverick Basin, is distinguished by stacked, high-energy facies including grainstone, packstone, and rudist patch reefs and associated facies. The San Marcos platform was a region of less subsidence relative to the other regions where the depositional environment varied through space and time from open marine to arid, hot, supratidal flats (Rose, 1972). Dolomite and dolomitic limestone are more abundant on the San Marcos platform than in the other regions. The dominant carbonate

\footnotetext{
${ }^{1}$ This section modified from Lindgren and others (2004, p. 8-27).
}

textures are massive and burrowed packstone and grainstone; collapse breccia, microscale and macroscale structures, calcitized evaporite, and rudist-reef detritus also were identified (Rose, 1972; Hovorka and others, 1996). The San Marcos platform facies of the Edwards Group have been divided into the Kainer and Person Formations (Rose, 1972) (fig. 10). The end of the time of formation of the Edwards Group (during the Washitan stage) is marked by a period of subaerial erosion and karstification (Rose, 1972). The Edwards Group was buried by as much as a thousand meters of predominantly deepwater, marine-shelf sediments deposited during marine transgression that characterized the later Cretaceous globally.

The Edwards aquifer is part of an aquifer system developed in thick and regionally extensive Lower Cretaceous carbonates that underlie large areas of Texas. Stratigraphically complex facies of the Lower Cretaceous, including sandstones, karstic limestones and dolomites, low permeability calcareous marl, and evaporite units, host the Trinity aquifer. The upper part of the Trinity aquifer, the Glen Rose Limestone, is overlain by limestone, dolomite, and altered evaporite of the Edwards aquifer. The stratigraphically equivalent units that compose the Edwards aquifer are the Kainer and Person Formations (Edwards Group) and overlying Georgetown Formation in the San Marcos platform (Rose, 1972) and the Devils River Limestone in the Devils River trend (fig. 10). The Edwards aquifer is overlain by the Upper Cretaceous Del Rio Clay, a thick, regionally distinctive shale that defines the top of the Edwards aquifer. Overlying the Del Rio Clay are, from oldest to youngest, the Upper Cretaceous Buda Limestone, Eagle Ford Group (dominantly shale), and Austin Chalk.

The Balcones fault zone is a system of high-angle normal faults with net displacement toward the Gulf of Mexico and constitutes the principal structural deformation affecting aquifer development. Most of the uplift of the Edwards Plateau along the Balcones fault zone took place in the Miocene (Ewing, 1991). This deformation extends from Bracketville, Tex., in the west to the east through San Antonio, where it bends and extends northeast past Austin, Tex. The underlying Ouachita structural belt provided a pivot between the uplifting of the Edwards Plateau and the subsidence of the adjacent Gulf Coastal Plain. The gentle southeastward dip of Cretaceous strata in the Edwards Plateau and Hill Country is interrupted across the Balcones fault zone by a system of en echelon faults that generally strike northeastward (Maclay, 1995). The faulting occurred along the subsurface axis of the Ouachita structural belt as a result of extensional forces created by the subsidence of basin sediments in the Gulf of Mexico (Mace and others, 2000). The vertical displacements of these faults vary along the strike of each individual fault. Faults of the Balcones fault zone in the local-scale study area are shown in figure 12 .

\section{Hydrogeologic Setting}

The hydrogeologic setting describes the hydrostratigraphy and karstic nature of the Edwards aquifer, as well as the 


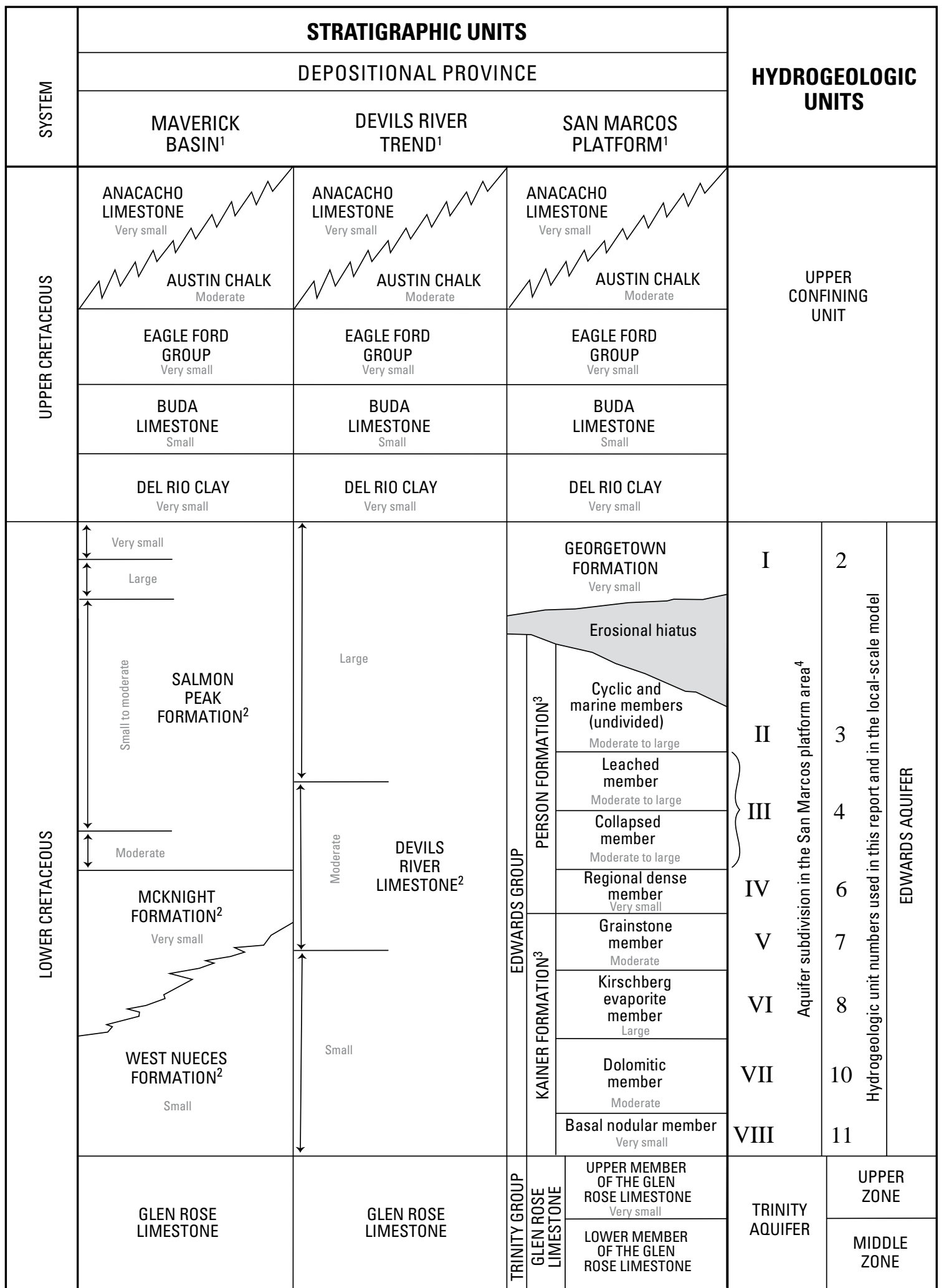

1 Location shown on figure 1.

Descriptors "very small, small, moderate, and large" refer to relative permeability of stratigraphic units.

2 Lozo and Smith (1964).

3 Modified from Rose (1972)

${ }^{4}$ Maclay and Small (1984).

Figure 10. Correlation of Cretaceous stratigraphic units and hydrogeologic units and their relative permeabilities in the San Antonio region, Texas. 
EXPLANATION
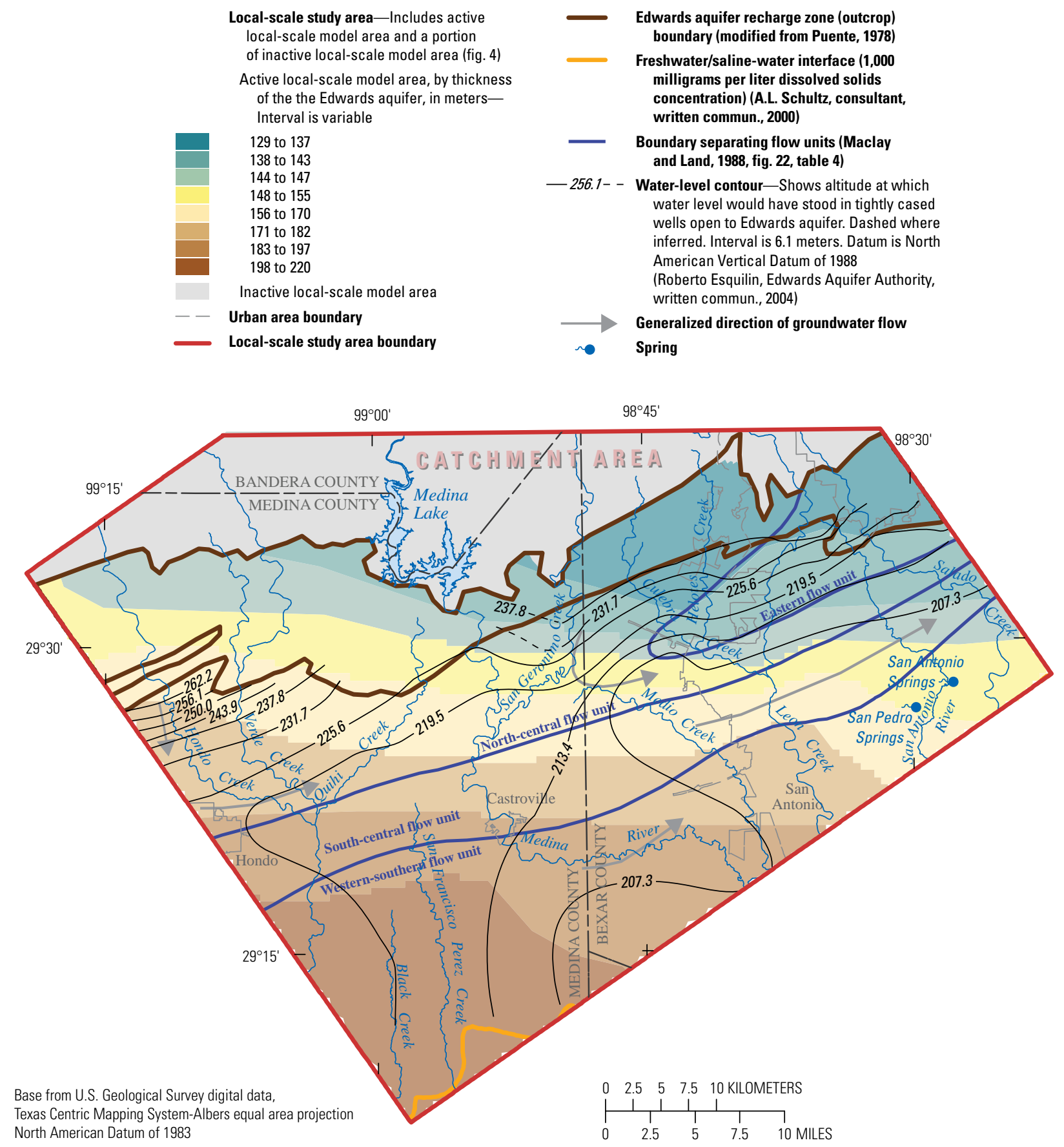

Figure 11. Thickness and measured potentiometric surface of the Edwards aquifer in the local-scale study area, 0 ctober 27 to November 2, 2001, San Antonio region, Texas. 


\section{EXPLANATION}
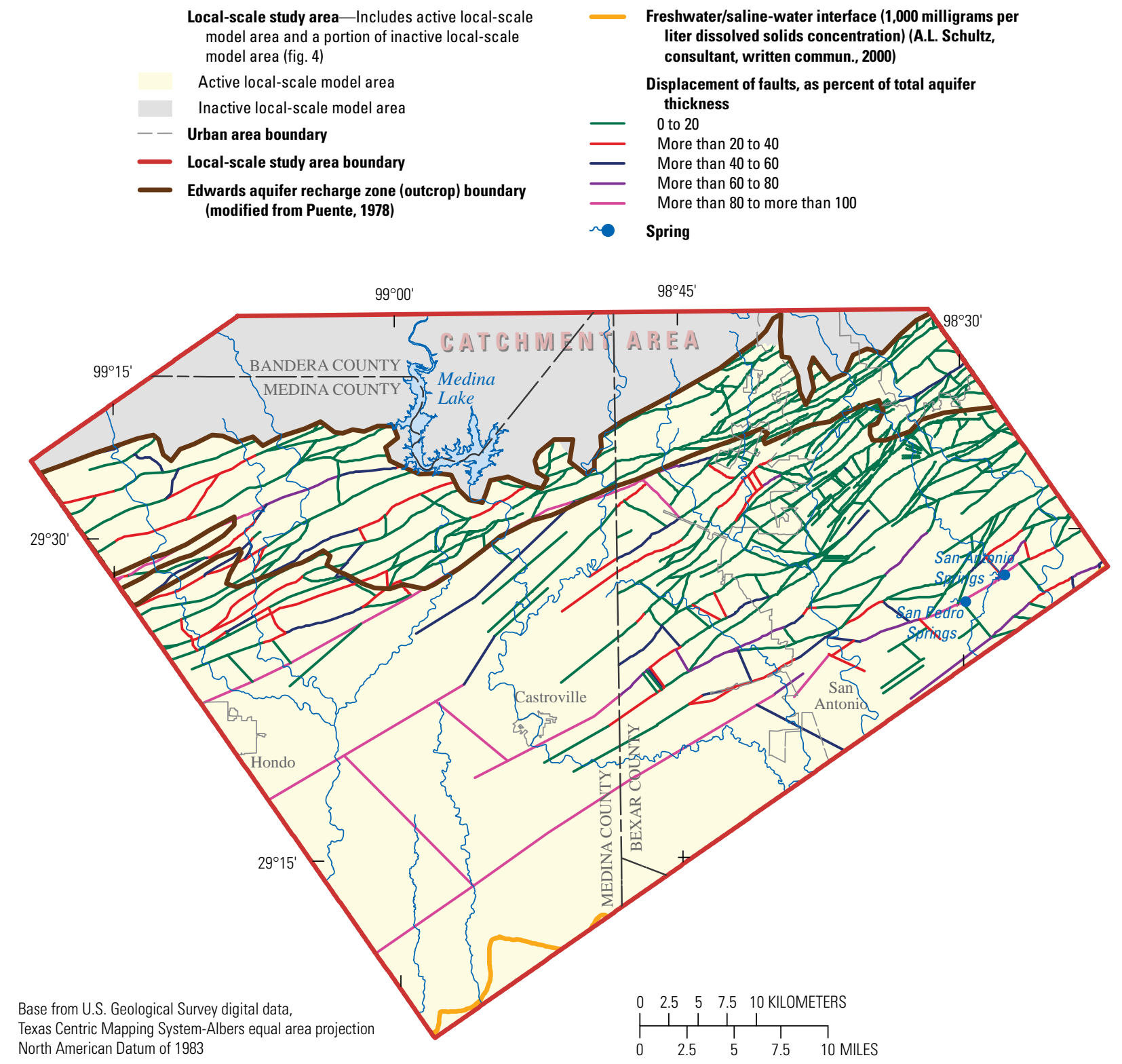

Figure 12. Locations and displacements of faults simulated in the local-scale model, San Antonio region, Texas.

structural and hydrologic features and hydraulic properties that influence groundwater flow in the aquifer. The groundwaterflow system and the sources of recharge to and discharge from the aquifer also are described.

\section{Hydrostratigraphy}

The Cretaceous strata of south-central Texas regionally include two aquifers: the Edwards aquifer in the Balcones fault zone and the Trinity aquifer in the Hill Country. The correlation chart (fig. 10) summarizes the relation among stratigraphic and hydrogeologic units and combines stratigraphic nomenclature with aquifer and confining-unit terminology (Lozo and Smith, 1964; Rose, 1972; Maclay and Small, 1984). The Trinity aquifer in the Hill Country, composed of sediments of the Trinity Group, has been divided into lower, middle, and upper zones (only the middle and upper zones are shown in fig. 10) on the basis of hydraulic characteristics of the sediments (Barker and Ardis, 1996; Mace and others, 2000). The upper zone of the Trinity aquifer generally has lower permeability than does the Edwards aquifer and, because of shaley interbeds, has a much lower vertical than horizontal permeability (Mace and others, 2000). The degree of hydraulic connection between the Trinity and Edwards aquifers might be limited in many areas by the relatively small permeabilities of the contiguous units (Maclay, 1995). 
Conventionally, the lower boundary of the Edwards aquifer is defined as the top of the Glen Rose Limestone (fig. 10).

Maclay and Small (1976, table 1) defined eight aquifer subdivisions within the Kainer, Person, and Georgetown Formations that compose the Edwards aquifer in the San Marcos platform of the Balcones fault zone (fig. 10). The eight aquifer subdivisions correspond to eight of the twelve hydrogeologic units defined for the local-scale model, discussed later in this report in the "Simulation of Groundwater Flow" section. Highly permeable intervals are variably distributed throughout units II, III, and VI, with the most permeable parts of these units occurring in honeycombed rock (Maclay, 1995). Groschen (1996) indicated that units III, VI, and VII transmit most of the groundwater within the San Antonio region. However, high-permeability dissolution features have been observed in all eight of the aquifer subdivisions. The Edwards aquifer contains carbonates that have numerous intervals of intercrystalline high porosity, as well as petrophysical properties that make the carbonates subject to development of karst conduits (Hovorka and others, 1998). In the San Antonio segment of the aquifer, interaction between lithologies and structure was observed to influence distribution of karst conduits (Hovorka and others, 1998).

The Georgetown Formation consists of stratigraphically distinct limestone that overlies and is generally of lower porosity and permeability than the Edwards Group. The contact is at least locally unconformable, with development of pre-Georgetown karst (Rose, 1972). The Georgetown Formation is commonly included within the Edwards aquifer because (1) there is no barrier to hydrologic connection between the Edwards Group and Georgetown Formation, (2) karst features are at least locally developed in the Georgetown Formation, and (3) it is difficult to separate the carbonates of the Edwards Group consistently from those of the Georgetown Formation by using the gamma-ray logs or drillers' reports commonly available for the subsurface (Scanlon and others, 2002).

The thick and regionally extensive shale of the Del Rio Clay directly overlies and confines the Edwards aquifer in downdip parts of the Balcones fault zone (freshwater and freshwater/saline-water transition zones in fig. 2). The high clay content and plasticity of the Del Rio Clay indicate that it generally functions as an effective barrier to vertical flow (Scanlon and others, 2002). The thick shales and marls of the Eagle Ford Group additionally confine the Edwards aquifer.

The confined part of the Edwards aquifer includes, on its downdip (gulfward) margin, the freshwater/saline-water transition zone (fig. 2). A small part of the freshwater/salinewater transition zone is present in the southwestern corner of the local-scale study area (fig. 3). The concentration of dissolved solids on the freshwater side of the transition zone ranges from about 250 to $300 \mathrm{mg} / \mathrm{L}$ (Pavlicek and others, 1987). The concentration of dissolved solids downdip of the transition zone rapidly increases in a gulfward direction to more than 250,000 mg/L (Maclay and Land, 1988). The locations of lines of equal concentration of dissolved solids ranging from 1,000 to 100,000 mg/L for the San Antonio segment of the Edwards aquifer have been mapped (Schultz, 1992, 1993, 1994; A.L. Schultz, consultant, written commun., 2000).

\section{Karst Hydrogeology}

A karst aquifer is an aquifer developed in soluble rocks with a permeability structure dominated by interconnected conduits dissolved from the host rock that facilitate the circulation of fluid in the downgradient direction wherein the permeability structure evolved as a consequence of dissolution by the fluid (Huntoon, 1995). An integrated aquifer-wide network of solutionally enlarged conduits with rapid flow characterizes karst aquifers (Huntoon, 1995; Worthington, 1999). These networks form tributary systems that discharge at springs (Worthington, 2004). Karst aquifers commonly are conceptualized as dual-flow systems that compose a continuum-flow system with Darcian flow comparable to porous media and a discrete conduit network frequently with turbulent flow conditions (Birk and others, 2003). Conduits having a wide range of spatial and temporal scales are common in karst aquifers. In many carbonate aquifers, the bulk of the water is transmitted, for unsaturated flow conditions (caves), by turbulent flow in solutionally enlarged conduits (Gale, 1984). Aquifer anisotropy and heterogeneity, inherent in carbonate aquifer systems, can affect both the direction and the velocity of groundwater flow. Fluid flow in karst carbonate aquifers can be highly variable and difficult to measure or predict.

Karst was developed contemporaneously with sedimentation at the top of and possibly within the Edwards Group on the San Marcos platform, and this karst has created a zone of high permeability of unknown continuity at the top of the Edwards aquifer (Maclay, 1995; Hovorka and others, 1998). Faulting had a critical role in aquifer evolution because it (1) increased permeability by forming fracture networks and (2) greatly increased hydraulic gradient by uplift of the base of the present-day Edwards aquifer to altitudes greater than $450 \mathrm{~m}$ above NAVD 88 in the northwestern part of the localscale study area, whereas at the downdip limit of the aquifer in the local-scale study area, the top of the aquifer is about $640 \mathrm{~m}$ below NAVD 88 at its deepest point. Introduction of freshwater into this heterogeneous and highly permeable carbonate rock created an extensive aquifer, which in turn modified the rock properties by the self-reinforcing mechanisms of preferential flow through larger aperture pores and preferential dissolution in zones of higher flow, which formed large, interconnected conduits (details of this process are described in Palmer [1991]). Epigenic karst theory assumes that karst features are produced only during downward or horizontal groundwater movement and are associated with recently recharged or meteoric waters and shallow, local flow systems. However, Klimchouk (2008) indicated that hypogenic speleogenesis, the formation of solution-enlarged permeability structures by waters ascending through soluble formations from below, is an important and widely occurring factor in karst development. Schindel and others (2008) indicate that hypogenic processes 
contributed to the formation and structure of the Edwards aquifer and the development of karst features. Hypogenic processes associated with discharge regimes of regional or intermediate flow systems dominated by upward flow likely interact with shallower and more local flow systems, supporting various dissolution mechanisms and the development of karst features.

An important factor influencing karst development is dissolution at depth. High permeability is developed in the confined part of the Edwards aquifer at depths of as much as 1,200 $\mathrm{m}$ below NAVD 88, as well as in the unconfined zone (Hovorka and others, 2004). Worthington (2001) demonstrated favored conduit development in parts of an aquifer deep below the water table, where flow paths are longer than about 3.0 $\mathrm{km}$, rather than in shallower parts. Stratigraphic control on karst formation is evident where caves, soft porous carbonate, and terra rossa infills occur preferentially at one horizon. In almost all outcrops, caverns have developed preferentially in former dolostones. Structural control on karst development is also very important. Hovorka and others (1998) described solution enlargement along fractures and solution enlargement producing caves along faults. Preferential development of caves in highly fractured zones adjacent to faults and in dolomitized intervals was observed in the outcrop area. Another variable influencing the development of karst is the hydrologic setting. Enhancement of matrix permeability is seen regionally near the freshwater/saline-water interface (Hovorka and others, 1998). Solution features are abundant in the outcrop area. Fractures, solution-enlarged fractures, and caves make up 1-3 percent of the outcrop area in the San Antonio segment of the Edwards aquifer (Hovorka and others, 1998).

Evidence of the karstic nature of the Edwards aquifer includes outcrop observations, subsurface data, hydrologic information, and tracer test results. Karst landforms in the outcrop include large (up to $1.6 \mathrm{~km}$ across, but more typically 3-300 $\mathrm{m}$ across), shallow, internally drained depressions (Hovorka and others, 2004; fig. 4A, p. 7); depressions of holes in creek bottoms; and small, upland features such as sinkholes and solution-enlarged fractures. Maclay (1995) indicated that fresh fractures in unconfined, freshwater parts of the Edwards aquifer outcrop and shallow subcrop evolved into cavernous openings near the water table. Hovorka and others (1998) reported that in two-dimensional cross section, karst features make up 1-5 percent of the area of the outcrop. Solution enlargement preferentially developed where faults and fractures intersect solution-prone beds. Vertical conduits, some filled with terra rosa sediments, are observed in some outcrops. Although deep conduits have not been entered by humans, the existence of karst in the deep saturated zone is known from borehole televiewer images of caves and solutionenlarged fractures, cave textures, and sediments recovered in cores, bit drops during well construction, oversize caliper logs, and off-scale porosity logs. Hovorka and others (1996) reported appreciable areas of coincidence between very high porosity and enlarged or off-scale caliper, which likely indicates borehole intersection of a cave or solution-enlarged bedding plane or fracture. This evidence of karst is found throughout the Edwards aquifer and is not focused in any particular structural or stratigraphic setting. Maclay and Small (1984) indicated that tubular openings or solution channels (conduits) probably exist in areas of homogeneous, dense, fractured limestone, particularly in the western part of the San Antonio region; these tubular openings are aligned along fractures and are oriented in the direction of groundwater flow. In the Edwards aquifer, measurements by Hovorka and others (1998) using several methods also show that about only 2 percent of the rock volume is occupied by $1.0-\mathrm{cm}$-scale or larger conduits. However, a recent cursory examination of geophysical logs and other borehole evaluation data indicated that voids $15 \mathrm{~cm}$ or larger, interpreted as conduits, were noted in 29 percent of the wells analyzed (A.L. Schultz, consultant, written commun., 2004). Such voids, typically less than 1.5 $\mathrm{m}$ thick, were detected over a broad area of the San Antonio segment of the Edwards aquifer. Halihan and others (2000) argue that hydraulic properties indicate that most wells are not closely connected to large-aperture conduits with turbulent flow.

Further evidence of flow through karst is the heterogeneous and rapidly responsive nature of water-level variation. Water-level altitudes in the aquifer and discharge at springs rise rapidly after rainfall and then decline at a variable rate, showing drainage from rocks characterized by both conduit and matrix permeability (Atkinson, 1977). Wells close together can have different responses to a single recharge pulse (Johnson and others, 2002). The response of springs to rainfall is rapid. The maximum lag between rainfall and peak springflow was 11 days or less at Comal Springs and 9 days or less at San Marcos Springs following an intense storm October 17-19, 1998, centered in Comal County (Tomasko and others, 2001). Similarly, the effects of watering restrictions in San Antonio in August 2000 indicate that spring response is less than 1 day (Worthington, 2004). Tracer testing in the San Antonio segment of the Edwards aquifer has shown rapid flow (velocities of 179.8 to 800.1 meters per day $(\mathrm{m} / \mathrm{d})$ over distances of 0.8 to $4.0 \mathrm{~km}$ ) from wells to the nearby high-flow springs (Ogden and others, 1986; Rothermel and others, 1987; Schindel and others, 2002). Rapid transmission of contaminants from several spill sites (Mace and others, 1997; Schindel and others, 2002) also indicates the likelihood that conduit flow systems are in the San Antonio segment of the Edwards aquifer.

A regionally extensive system of high-permeability zones is defined by broad troughs in the potentiometric surface (conduit indicators) in the confined zone of the Edwards aquifer. Three approximately synoptic water-level maps constructed by Hovorka and others (2004; figs. 7, 8, and 9, p. 20, 21 , and 22, respectively) indicate a wide trough that extends westward from central Bexar County to western Medina County. This trough is clearly defined in synoptic surveys compiled by the Edwards Aquifer Authority (EAA) (Roberto Esquilin, Edwards Aquifer Authority, written commun., 2003; Hovorka and others, 2004; fig. 10, p. 23) and has been 
recognized as a zone of high transmissivity in previous models (Klemt and others, 1979; Maclay and Land, 1988; Painter and others, 2002; Lindgren and others, 2004). Worthington (2004) conceptualized a dendritic pattern of conduit connection from the recharge zone to the confined zone. Maclay and Small (1984) hypothesized that solution channels within the Edwards aquifer might be oriented parallel to the courses of streams recharging the Edwards aquifer and that vertical solution channels are well developed below segments of stream courses in the recharge zone. Relatively high porosity and permeability in the deepest parts of the aquifer near the freshwater/salinewater interface, anomalously high well yields, and sharp chemical gradients indicate that flow might be focused in this area.

Shallow flow paths, close to the water table, commonly have been considered the most favored locations for conduits (Thrailkill, 1968; Maclay, 1995). However, abundant evidence exists for solution activity deep within carbonate aquifers. An analysis by Worthington (2004, p. 19) for three possible flow paths from the Frio River to Comal Springs indicated that "deeper parts of the Edwards aquifer are favored over shallower parts for conduit development, even when the deep flow path is up to 24 percent longer than the shallow flow path." Grabens and synclines are particularly favorable sites for development of conduits, offering the advantages of deeper flow paths without the disadvantages of long flow paths (Worthington, 2004). Large-scale structural troughs with increased flow occur in the Edwards aquifer, and conduit development in these is favored. Worthington (2004; fig. 17, p. 20) identified nine major structural troughs in the San Antonio segment of the Edwards aquifer, including troughs in Medina and Bexar Counties.

\section{Hydraulic Properties}

Extensive data have been collected on the hydraulic properties of the Edwards aquifer in the San Antonio region. The hydraulic properties of primary interest for this report include hydraulic conductivity, permeability, anisotropy, and porosity. Hydraulic conductivity is a quantitative measure of the ability of a material to transmit water and is a property of both the medium (aquifer material) and the fluid (Lohman, 1972, p. 6). The term "permeability" is commonly used in the extensive literature pertaining to the Edwards aquifer (see, for example, Hovorka and others, 1996, 1998; Halihan, Mace, and Sharp, 2000; Mace and Hovorka, 2000). Permeability is used in this report (1) for a qualitative description of the ability of materials to transmit water and (2) in relation to aquifer structure, for example when referring to matrix, fracture, and conduit permeability.

A qualitative interpretation of the distribution of relative permeability by stratigraphic unit of the Edwards aquifer and its confining units is shown in figure 10. These qualitative interpretations of relative permeability are based on field observations, stratigraphic studies by Rose (1972), and data from test-drilling and geophysical-logging programs (Maclay and Small, 1983). For the Edwards aquifer, these estimates apply to the confined zone and might not be strictly applicable to the unconfined zone. Hydraulic conductivity in the Edwards aquifer varies over eight orders of magnitude, and it is multimodal (Hovorka and others, 1998). Matrix, fracture, and conduit permeability occur in the Edwards aquifer. The carbonate matrix of the Edwards aquifer is very permeable; however, in many intervals, the very high permeabilities resulting from conduits and fractures dwarf the matrix contribution. In relation to structural position, Hovorka and others (1998) found high permeability more frequently in the deeper parts of the Edwards aquifer than in the parts where the top of the aquifer is higher than about $61 \mathrm{~m}$ above NAVD 88. Outcrops, which are at the highest altitudes, show abundant dissolution features and additional karst features that have developed in near-surface settings; however, matrix porosity and permeability of outcrop rocks are low relative to those in the aquifer. The highest matrix permeability occurs in downdip parts of the Edwards aquifer, where mixing of freshwater and saline water has maximized dolomite dissolution (Hovorka and others, 1998). High matrix permeability is observed on both sides of the freshwater/saline-water interface.

Hydraulic conductivity and transmissivity of the Edwards aquifer each vary over several orders of magnitude (table 3 at end of report). The estimates of mean hydraulic conductivity by Hovorka and others (1998) were increased by a minimum factor of about 5 if specific-capacity tests with no measurable drawdown were included. Mean hydraulic conductivity of the confined zone is more than 120 times greater than mean hydraulic conductivity in the recharge zone. Based on experimental and theoretical semivariograms (statistically based, qualitative functions that characterize spatial continuity of a dataset - that is, how quickly values change with changing distance and direction in space), Hovorka and others (1998) concluded that small-scale variability in hydraulic conductivity is large; even closely spaced measurements might differ by a factor of 1,000 . The small-scale randomness most likely reflects the variable contributions of matrix, fracture, and conduit permeability to the measured average value obtained in aquifer tests. Vertical variations in permeability in the Edwards aquifer indicate that the entire aquifer is highly permeable, as well as highly variable. Structurally influenced cave systems contribute the highest hydraulic conductivities (30.8 to $32.3 \mathrm{~m} / \mathrm{d}$ ), solution-enhanced fractures and stratigraphically controlled karst contribute intermediate values, and the porous carbonate matrix contributes hydraulic conductivities of $3.0 \times$ $10^{-4}$ to $30.8 \mathrm{~m} / \mathrm{d}$ (Hovorka and others, 1998). Matrix permeability accounted for a large fraction of the permeability in intervals of low hydraulic conductivity determined from aquifer tests. In intervals of relatively high hydraulic conductivity from tests, the matrix contribution was less than 1 percent.

Anisotropy of an aquifer is indicated when the hydraulic conductivity shows variations with the direction of measurement at any given point in a geologic formation. Therefore, an anisotropic aquifer will have a greater hydraulic conductivity 
in one or more directions depending upon geologic and hydrologic conditions. Anisotropy either can be intrinsic to the geologic material (such as that caused by the platey bedding of the components of clayey materials) or can be caused by the directional persistence of heterogeneous features, such as conduits. Both Hovorka and others (2004; fig. 24, p. 41) and Worthington (2004; fig. 21, p. 31) postulate the presence of conduits that coincide with major flow paths in the Edwards aquifer. Factors that likely influence anisotropy in the aquifer also include the presence of barrier faults with large vertical displacements. The disruption of groundwater flow by faults might be strongly influenced by major disruptions in the lateral continuity of highly permeable strata. The quantitative magnitude of anisotropy of the Edwards aquifer is largely unknown. The ratio of anisotropy (ratio of y-direction hydraulic conductivity to $\mathrm{x}$-direction hydraulic conductivity) derived from past digital-model analysis ranges from 0:1 (hydraulic conductivity in the y-direction is zero, caused, for example, by a barrier fault) to 1:1 (aquifer is isotropic) (Maclay and Land, 1988). The regional maximum directional hydraulic conductivity is aligned parallel with structural features and prevailing groundwater flow paths.

The amount and distribution of water in the Edwards aquifer are related to the development of porosity and the storage characteristics of the aquifer. Hovorka and others (1996) estimated that Edwards aquifer porosity varies vertically from lows of 4-12 percent to highs of 20-42 percent, with an average for the entire aquifer of 18 percent (table 3 ). Kuniansky and others (2001) found that an effective porosity of 1-3 percent was needed for the karst Edwards aquifer system in Texas to match estimated traveltimes derived from geochemical mixing models.

\section{Groundwater-Flow System}

Groundwater flow in karst typically includes diffuse or matrix flow (slow flow system), flow through fractures, and flow through large conduits (fast flow system). Flow in conduits is rapid, often turbulent and restricted to discrete pathways, whereas flow in the matrix system is more comparable to Darcian flow in porous media (Shuster and White, 1971). Atkinson and Smart (1981) reported that the presence of turbulent flow in conduits is the definitive characteristic of karst aquifers. Hauwert, Johns, and Sharp (2002), Hauwert, Sansom, and others (2002), Schindel and others (2002), and Worthington (2004) presented results indicating that turbulent flow occurs in conduits in the Edwards aquifer. The porous matrix rock can act either as a sink draining water from the conduits or as a source supplying the conduits with water from the aquifer storage (Bauer and others, 2003). In the Edwards aquifer, high matrix porosity and permeability likely are overshadowed by high permeability developed in structurally influenced karstic conduit systems that transmit water into, through, and out of the aquifer system. The groundwaterflow system of the Edwards aquifer in the San Antonio region includes the following components (figs. 2, 13):
1. The catchment area in the Edwards Plateau, where the rocks of the Edwards-Trinity and Trinity aquifers are exposed and receive direct recharge to the water table. Erosion has removed Edwards Group rocks at the southern margin of the plateau (Hill Country), leaving only the Trinity aquifer present (fig. 13).

2. The recharge zone in the northern and northeastern parts of the Balcones fault zone, where streams lose flow directly into the unconfined Edwards aquifer and where the aquifer receives direct recharge to the water table.

3. The confined zone in the southern and southeastern part of the Balcones fault zone, which comprises the freshwater zone and the freshwater/saline-water transition zone.

A potentiometric-surface map for the Edwards aquifer based on water-level measurements made during October and November 2001 (Roberto Esquilin, Edwards Aquifer Authority, written commun., 2004) (fig. 11). indicates that water that entered the catchment area and recharge zone moves from unconfined to confined parts of the aquifer through generally southeasterly flow paths. In the confined zone, the water moves under low hydraulic gradients through fractured, highly transmissive, cavernous strata toward the east and northeast, where it is discharged through springs and wells. Regionally the hydraulic gradients include (1) a broad, low-gradient part of the aquifer in the confined zone in Medina and Bexar Counties and (2) generally steep gradients across the transition from the unconfined to confined parts of the Edwards aquifer.

Conduits could be major contributors to flow in the Edwards aquifer (Hovorka and others, 2004; Worthington, 2004). The multimodal hydraulic conductivity distribution of the Edwards aquifer (Hovorka and others, 1998) implies that the fastest moving water can travel many times faster than the largest volume of water. The contribution of matrix permeability to regional-scale hydraulic conductivity likely is minor, and most Edwards aquifer water flows through fractures and conduits (Hovorka and others, 1998). Both Hovorka and others (2004; fig. 24, p. 41) and Worthington (2004; fig. 21, p. 31) inferred the presence of conduits and major flow paths from central Bexar County to western Medina County, with an east-west orientation that indicates structural influence. Hovorka and others (2004) postulated a complex of interconnected conduits, with about one-half the segments parallel to faults and one-half of them crossing faults at an appreciable angle. The presence of conduits and major flow paths also are indicated along parts of the freshwater/saline-water interface in Medina and western Bexar Counties.

Faults can either increase or decrease permeability (Hovorka and others, 1998). Some of the abundant, interconnected fractures in intensely fractured zones adjacent to faults have been enlarged, and they might focus flow parallel to faults. Where calcite cement fills breccia, cross-fault flow might be decreased. Stratigraphic offset of permeable zones along faults 


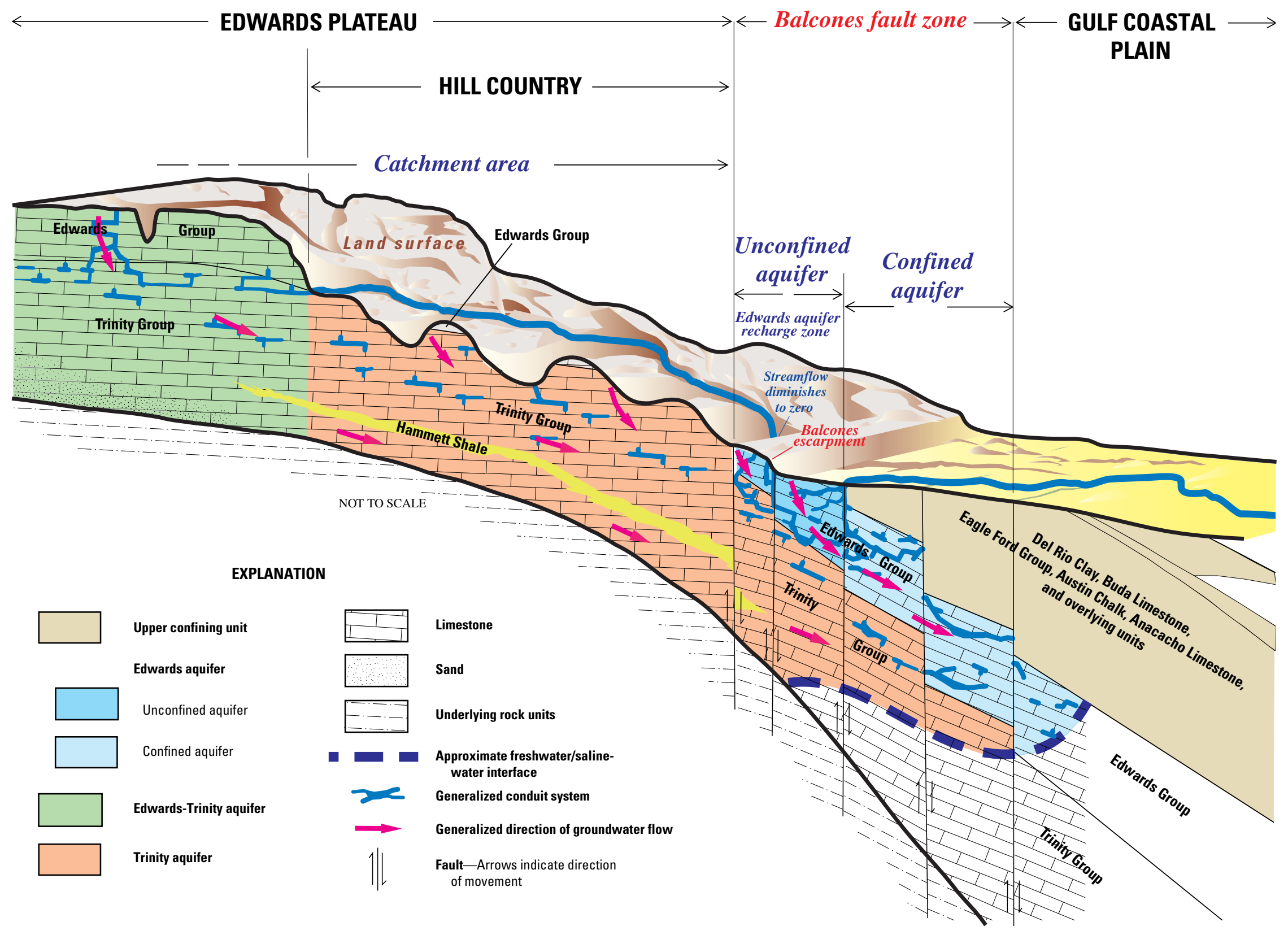

Figure 13. Generalized north to south hydrogeologic section and potential paths of groundwater flow for the local-scale study area, San Antonio region, Texas (modified from Barker and Ardis, 1996, plates 1 and 3). 
might also decrease the cross-fault flow (Maclay and Small, 1983, 1984). Holt (1959) observed nearly $30.5 \mathrm{~m}$ of head difference across faults in northern Medina County, and George (1952) reported head differences of 1.8-7.9 m across segments of major faults in unconfined, less-permeable parts of the aquifer in Comal County. Maclay (1995) and Groschen (1996) characterized flow in the Edwards aquifer as being controlled laterally by barrier faults that locally compartmentalize the aquifer, especially toward the eastern part of the San Antonio segment. Maclay and Land (1988) and Clark and Journey (2006) hypothesized that large-throw faults segment the aquifer and divert flow entering the recharge zone on relay ramps to the west before flow is redirected toward the east.

Several 4.8- to 11.3-km-long sections of large-throw faults are coincident with a steep gradient between the confined and unconfined sections of the Edwards aquifer, which would indicate that faults or stratigraphic juxtaposition limit cross-fault flow. Notches in water-level maps, however, indicate that more permeable zones provide connections between the recharge zone and the confined aquifer (Hovorka and others, 2004). Some areas of steep hydraulic gradient are coincident with faults, but in most areas the water-level change appears to be gradational rather than sharp. Only at large-throw faults is there a transition directly from recharge (unconfined) zone to confined zone across a fault boundary.

Hovorka and others (2004) determined the saturated thickness of the San Antonio segment of the Edwards aquifer, computed as the water-level altitude minus the altitude of the top of the Trinity aquifer (Glen Rose Limestone). The findings indicate that the Edwards Group is saturated over only a part of the recharge zone, which indicates that recharge flows through the Edwards Group into the upper beds of the underlying Glen Rose Limestone before returning to the Edwards Group. Veni (George Veni and Associates, written commun., 2003) has documented cave patterns in the northern Bexar County area, as well as other locations in the Edwards aquifer recharge zone, that indicate that the upper part of the Glen Rose Limestone is hydrologically connected to the Edwards Group.

\section{Recharge}

The Edwards aquifer is recharged through (1) seepage losses in streambeds of surface streams that drain the Hill Country, where the streams flow onto the outcrop of the Edwards aquifer; (2) infiltration of rainfall on the outcrop in interstream areas; (3) subsurface inflow across the updip margin of the Balcones fault zone, where the Trinity aquifer is laterally adjacent to the downfaulted Edwards aquifer (LBGGuyton Associates, 1995); and (4) movement of water from the Trinity aquifer into the overlying Edwards aquifer. The primary source of recharge is seepage from streams crossing the outcrop of the Edwards aquifer (hence, the outcrop is synonymous with the recharge zone). In the catchment area (fig. 2), streams gain water as they flow over low-permeability Glen Rose Limestone, which is at the surface over most of the catchment area. Streams become predominantly losing streams and recharge the Edwards aquifer as they cross the outcrop. Reported percentages of the total recharge that occurs as infiltration of rainfall on the outcrop in interstream areas, rather than as seepage losses through streambeds, are (1) 15 percent for the Barton Springs segment of the Edwards aquifer (Slade and others, 1985; Scanlon and others, 2002) and (2) 20 percent (Klemt and others, 1979; Thorkildsen and McElhaney, 1992) and 40 percent (Maclay and Land, 1988) for the San Antonio segment (fig. 1). Major streams that cross the recharge zone of the Edwards aquifer in the local-scale study area are the Medina River and Hondo and Salado Creeks (fig. 3).

Water moves from stream channels to the water table of the unconfined Edwards aquifer in the recharge zone, where the water table is at depths generally greater than $30.5 \mathrm{~m}$ below the streambeds. All of the base flow from the catchment area (fig. 13) and some of the storm runoff of streams crossing the recharge zone infiltrate to the unconfined aquifer. Karst features and faults occur in the recharge zone and may provide pathways for water to move rapidly from land surface to the water table. Estimates of the combined recharge to the San Antonio segment of the Edwards aquifer from stream seepage and infiltration of rainfall range from a low of 53.9 million $\mathrm{m}^{3}$ during 1956 to a high of 3,066.8 million $\mathrm{m}^{3}$ during 1992 (Hamilton and others, 2003). The long-term (1934-2002) mean annual recharge to the Edwards aquifer is 862.2 million $\mathrm{m}^{3}$ (median 688.1 million $\mathrm{m}^{3}$ ) and for 1993-2002 is 979.6 million $\mathrm{m}^{3}$ (median 710.9 million $\mathrm{m}^{3}$ ) (Hamilton and others, 2003). Much of the annual flow of the Medina River is impounded in Medina Lake (U.S. Army Corps of Engineers, 1965). Of the volume impounded, about one-half seeps into the Edwards aquifer from the lake and its irrigation facilities (U.S. Army Corps of Engineers, 1965).

Monthly rates of recharge for the San Antonio segment of the Edwards aquifer from seepage losses from streams and infiltration of rainfall in the recharge zone are computed from records of stream-gaging stations near upstream and downstream limits of the recharge area and from estimated runoff in the recharge area (Puente, 1978). Recharge by seepage losses from streams in the drainage area of a losing stream is computed by subtracting the flow at the downstream station from the sum of the flow at the upstream station and estimated inflow from adjacent interstream areas. Recharge by infiltration of rainfall is estimated on the basis of unit runoff from the catchment area (Puente, 1978). Groundwater evapotranspiration losses are assumed negligible because of the depth of the water table below land surface in the recharge zone. The recharge subzones present in the local-scale model area are (1) 80 percent of the area between the Sabinal and Medina Rivers subzone, (2) 100 percent of the Medina River subzone, and (3) 69 percent of the area between Medina River and Cibolo-Dry Comal Creek subzone (fig. 4). Monthly recharge estimates computed by the USGS, by recharge subzone, for the local-scale study area for 2001 are shown in table 4 at end of report. The percentages of area cited are the area of each recharge subzone in the local-scale model area compared to 
the total area of the recharge subzone (San Antonio segment of the Edwards aquifer). The percentages of the total recharge contributed by each recharge subzone are 39,29 , and 32 percent for the area between the Sabinal and Medina Rivers, the Medina River, and the area between the Medina River and Cibolo-Dry Comal Creek subzones, respectively.

The Edwards aquifer in much of the Balcones fault zone is juxtaposed against the Trinity aquifer both at the surface and at depth, and the Trinity aquifer likely discharges directly into the Edwards aquifer. The volume of water that moves laterally from the Trinity aquifer into the Edwards aquifer currently (2010) cannot be explicitly measured. A number of studies have shown, either through hydraulic or chemical analyses, that groundwater likely flows from the Trinity aquifer into the Edwards aquifer (Long, 1962; Klemt and others, 1979; Walker, 1979; Senger and Kreitler, 1984; Slade and others, 1985; Maclay and Land, 1988; Waterreus, 1992; Stein, 1993; Veni, 1994, 1995). Both units are karstic limestones, and large caves that cross the contact are interpreted as evidence that cross-formational flow occurs through karst systems in at least parts of the San Antonio segment of the Edwards aquifer (Veni, 1988; Vauter, 1992). Mace and others (2000) indicated that groundwater from the Trinity aquifer discharges to the south and east in the direction of the Edwards aquifer. The volume of flow from the Trinity aquifer into the Edwards aquifer can only be estimated. The available estimates vary, ranging from about 2 percent to 6 percent of total average annual recharge to the Edwards aquifer (Woodruff and Abbott, 1986; LBG-Guyton Associates, 1995). A flow of about 79.0 million cubic meters per year $\left(\mathrm{m}^{3} / \mathrm{yr}\right)$ from the upper and middle zones of the Trinity aquifer in the direction of the Edwards aquifer, representing about 9 percent of the average estimated annual recharge to the Edwards aquifer, was simulated by Mace and others (2000). Lindgren and others (2004) reported simulated inflow from the Trinity aquifer into the Edwards aquifer at the northern recharge zone boundary for the San Antonio and Barton Springs segments of the Edwards aquifer for a steadystate simulation of 49.7 million $\mathrm{m}^{3} / \mathrm{yr}$, about 6.9 percent of the simulated recharge to the aquifer. For a transient simulation, simulated inflow from the Trinity aquifer ranged from about 3.4 percent of the total simulated sources to the aquifer during a period of above-normal rainfall and recharge to about 39.4 percent during a period of drought.

\section{Discharge}

Discharge from the Edwards aquifer occurs (1) as withdrawals by municipal, industrial, irrigation, and livestock wells and (2) as springflow. Groundwater withdrawals by wells have increased with increasing population. From 1934 through 2002, the lowest estimated annual pumpage (withdrawals) for the San Antonio segment of the Edwards aquifer was 125.7 million $\mathrm{m}^{3}$ in 1934 , and the highest was 669.1 million $\mathrm{m}^{3}$ in 1989 (Hamilton and others, 2003).

Springflow from the San Antonio segment averaged 459.2 million $\mathrm{m}^{3} / \mathrm{yr}$ (median 463.6 million $\mathrm{m}^{3} / \mathrm{yr}$ ) for $1934-2002$
(Hamilton and others, 2003). Total annual springflow from the Edwards aquifer has varied as much as an order of magnitude over the period of record. Springflow totaled 86.1 million $\mathrm{m}^{3}$ in 1956 during the 1950s drought and reached a record high of 990.4 million $\mathrm{m}^{3}$ in 1992 (Hamilton and others, 2003). Annual total discharge from the San Antonio segment generally has increased since the mid-to-late 1960s. This increase largely results from an approximate doubling of the well pumpage.

Thousands of water wells tap the Edwards aquifer in the San Antonio region. Annual discharge by wells increased steadily at an average annual rate of about 5.6 million $\mathrm{m}^{3} / \mathrm{yr}$, more than tripling between 1939 and 2000 (Hamilton and others, 2003). Estimated annual groundwater withdrawals from the Edwards aquifer by wells in the local-scale study area during 2001 were 264.1 million $\mathrm{m}^{3}$ (table 5 at end of report). Mean daily and mean annual groundwater withdrawal rates for wells in the local-scale study area, by water-use type, are shown in table 5. Municipal and industrial water use account for about 82 percent of annual withdrawals from the Edwards aquifer in the local-scale study area (table 5), primarily in the San Antonio region in the eastern part of the study area. Irrigation accounts for about 17 percent of annual groundwater withdrawals in the local-scale study area (table 5), primarily in Medina County in the western part of the study area. The locations of groundwater withdrawal wells in the local-scale study area are shown in figure 14. Groundwater withdrawals are primarily from the confined part of the Edwards aquifer, with the largest withdrawals in and around San Antonio.

Yields of more than 2.0 million $\mathrm{m}^{3} / \mathrm{yr}\left(3.8 \mathrm{~m}^{3} / \mathrm{min}\right)$ are common for wells in the confined freshwater zone of the Edwards aquifer (Maclay, 1995). Yields of wells commonly are limited more by the capacity of the pumps to discharge water than by the productivity of the aquifer. The density of wells in the unconfined recharge zone of the aquifer is substantially less than that in the confined zone, and typically the yields are smaller. The smaller yields are the result of generally less saturated thickness and hydraulic conductivity in the unconfined zone.

Springs and seeps are the major natural discharge outlets for the Edwards aquifer, accounting for nearly all natural discharge from the aquifer (Maclay, 1995). San Antonio and San Pedro Springs in Bexar County are the largest springs in the local-scale study area, with mean flow rates of 0.91 cubic meters per second $\left(\mathrm{m}^{3} / \mathrm{s}\right)\left(28.7\right.$ million $\left.\mathrm{m}^{3} / \mathrm{yr}\right)$ and $0.24 \mathrm{~m}^{3} / \mathrm{s}$ (7.6 million $\mathrm{m}^{3} / \mathrm{yr}$ ), respectively, during 2001 (Hamilton and others, 2003). Groschen (1996) postulated that the locations of most major springs in the Edwards aquifer are structurally controlled. Groundwater flow is diverted along barrier faults, with vertical openings at a few places along faults where springs can emerge. Structural constrictions can also facilitate the rise of water along faults. San Antonio and San Pedro Springs discharge groundwater that rises along a major fault. A structural horst near the fault acts as a barrier to groundwater flow in a complex graben and diverts flow around its northern 


\section{EXPLANATION}

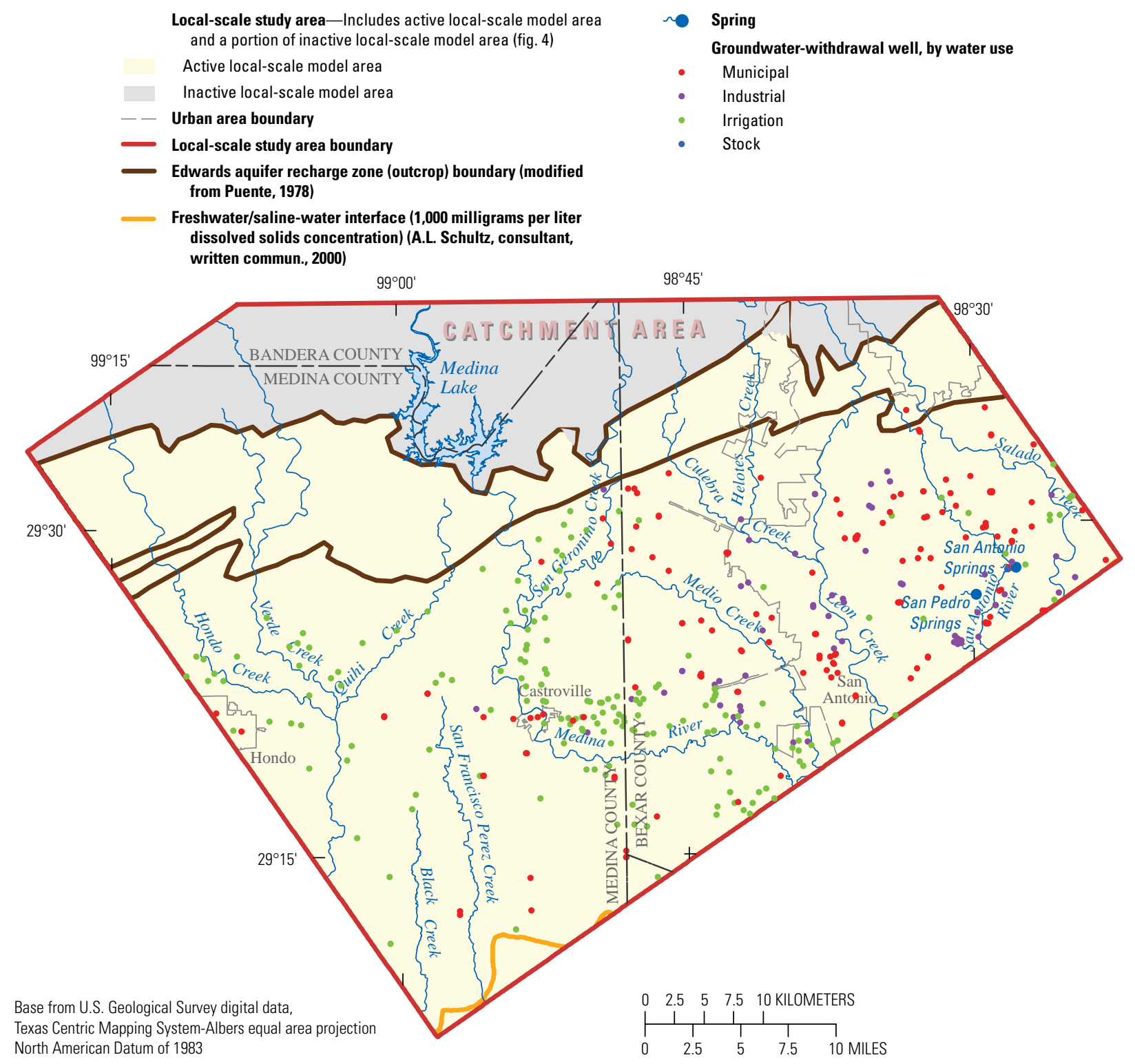

Figure 14. Locations of groundwater withdrawal wells in the local-scale study area, San Antonio region, Texas.

and southern margins, some of which emerges as springflow (Maclay, 1995).

Increased pumpage, primarily from wells in San Antonio, has resulted in frequent periods of zero discharge from San Antonio and San Pedro Springs (Brune, 1975). San Antonio Springs has flowed intermittently since 1950 - but only during periods of relatively high water-level altitudes. Periods of zero discharge have been appreciably more frequent and of longer duration for San Antonio Springs than for San Pedro Springs. Extended periods of zero discharge for San Antonio Springs include June 1949 to February 1958, June 1962 to April 1965, July 1965 to December 1967, July 1982 to October 1985, June
1988 to November 1991, and May 1995 to May 1997. In contrast, the only extended period of zero discharge lasting more than 1 year for San Pedro Springs was July 1951 to October 1957. However, the discharge from San Antonio Springs typically is much greater than for San Pedro Springs, for example, 72.3 million $\mathrm{m}^{3} / \mathrm{yr}\left(2.3 \mathrm{~m}^{3} / \mathrm{s}\right)$ for San Antonio Springs compared to 12.3 million m $3 / \mathrm{yr}\left(0.4 \mathrm{~m}^{3} / \mathrm{s}\right)$ for San Pedro Springs in 2002. The more frequent and longer duration periods of zero discharge combined with greater magnitudes of discharge for San Antonio Springs relative to San Pedro Springs reflect the larger discharge capacity and higher spring orifice altitude for San Antonio Springs. 


\section{Simulation of Groundwater Flow}

The local-scale groundwater-flow model simulates steady-state conditions in the Edwards aquifer that are representative of long-term stresses, including recharge and pumpage. Average stresses (recharge and pumpage) during 2001, a representative year for a recent time period (2000-10), were used to simulate steady-state conditions, as discussed in the "Development and Application of Groundwater Flow and Particle-Tracking Models" section of this report. Differences between measured and simulated water-level altitudes (residuals) were calculated for 84 wells to compare measured mean water-level altitudes to simulated water levels from the model. The 84 wells were as follows: (1) the 6 wells installed for the TANC local-scale study from 2007 to 2010, (2) 6 wells in the vicinity of the selected PSW equipped with water-level recorders from 2007 to 2010 for the TANC local-scale study, and (3) 72 monitoring wells measured biannually by EAA during 2001 (table 6 at end of report). Residuals between measured and simulated water-level altitudes are shown in table 6 . The measured and simulated springflow volumes and their residuals for San Antonio Springs and San Pedro Springs are also shown in table 6.

The rediscretized regional Edwards aquifer models developed for the regional TANC study (Lindgren and others, 2011) were used to provide initial water-level altitudes, groundwater withdrawal rates, recharge rates, selected initial hydraulic properties, drain locations, and initial drain hydraulic conductances for the local-scale model. Specified fluxes at the lateral boundaries of the local-scale model were derived from the simulated flows from the diffuse-flow rediscretized regional Edwards aquifer model. The local-scale model grid covers about $4,249 \mathrm{~km}^{2}$ and, like the rediscretized regional Edwards aquifer models, is rotated 35 degrees counterclockwise from horizontal. The local-scale model grid has a finer vertical discretization than do the rediscretized regional Edwards aquifer models and incorporates refined parameter zones corresponding with multiple hydrogeologic units. The local-scale model simulations also use the MODFLOW Hydrogeologic-Unit Flow Package (Anderman and Hill, 2000) and include two hydrogeologic units that are intended to simulate fast flow paths attributable to karst features. The selected initial hydraulic properties and initial drain hydraulic conductances from the rediscretized regional Edwards aquifer models were revised in the local-scale model during model calibration.

\section{Model Description}

A description of the local-scale model includes the structure and hydraulic properties of the aquifer, the boundary conditions imposed, and the stresses on the aquifer. Pertinent hydraulic and hydrologic characteristics of the aquifer for appropriate cells within the grid are needed to solve the governing partial-differential equation. Specific parameters required for the local-scale model include (1) active and inactive cells, (2) elevations of the top and bottom of model layers, (3) fault locations and horizontal conductance, (4) horizontal hydraulic conductivity, (5) horizontal and vertical anisotropy, (6) boundary fluxes, (7) recharge rates, (8) groundwater withdrawal rates, (9) drain elevation and conductance, and (10) initial water-level altitudes.

The FORTRAN computer-model code MODFLOW-2000 (Harbaugh and others, 2000), a modular finite-difference groundwater flow code developed by the USGS, was used to simulate groundwater flow in the Edwards aquifer. The local-scale model uses the Basic, Output Control, Hydrogeologic-Unit Flow, Recharge, Well, Horizontal-Flow Barrier, Drain, and Geometric Multigrid (GMG; numerical solver) MODFLOW modules, or "packages," to simulate groundwater flow in the Edwards aquifer. The software Groundwater Vistas version 5 (Groundwater-vistas.com, A Division of Scientific Software Group, Sandy, Utah) was used as a preprocessor and postprocessor to facilitate data entry and allow analysis of model output (Environmental Simulations, Inc., 2007).

The MODFLOW Hydrogeologic-Unit Flow (HUF) Package (Anderman and Hill, 2000) is an alternative internal flow package that allows the vertical geometry of the system hydrogeology to be defined explicitly within the model by using hydrogeologic units that can be different from the definition of the model layers. The geometry of the hydrogeologic units is defined independently of the model layers. For the MODFLOW Groundwater Flow Process, the HUF Package calculates effective hydraulic properties for the model layers on the basis of the hydraulic properties of the hydrogeologic units, which are defined by using parameters. The hydraulic properties are used to calculate the conductance coefficients and other terms needed to solve the groundwater-flow equation. The HUF Package supports parameters that are used to define the following hydraulic properties, which are listed with their parameter type in parentheses: horizontal hydraulic conductivity (HK), horizontal anisotropy (HANI), vertical hydraulic conductivity (VK), vertical anisotropy (VANI), specific storage (SS), and specific yield (SY).

\section{Model Geometry and Discretization}

The uniformly spaced finite-difference grid used to spatially discretize the model area for the local-scale model has 300 rows and 350 columns and is rotated 35 degrees counterclockwise from horizontal (fig. 4). The dimensions of the grid cells are uniformly $201.2 \mathrm{~m}$ along rows and columns, the same as the dimensions for the rediscretized regional Edwards aquifer models (Lindgren and others, 2011). The local-scale model grid includes areas beyond the boundaries of the recharge zone to the north. Model cells in these areas were made inactive (no-flow cells), which resulted in about 63 percent of the cells in the grid being active. The localscale model has 92 layers, each with a uniform thickness of $8 \mathrm{~m}$ and top and bottom surfaces that dip downward to the south and east with a uniform slope, following the general 
slope of the top of the Edwards aquifer. The layer thickness of $8 \mathrm{~m}$ was chosen as an acceptable trade-off between maximizing the vertical discretization for particle tracking purposes and minimizing the total number of cells in the model. The local-scale model includes 12 HGUs, whose properties are defined by using the HUF Package. The 12 HGUs include 8 HGUs previously defined for the Edwards aquifer (Maclay, 1995, fig. 11), 2 HGUs with high hydraulic conductivities (one or more orders of magnitude higher than for the other HGUs) ("conduit" HGUs), 1 HGU overlying the Edwards aquifer, and $1 \mathrm{HGU}$ underlying the Edwards aquifer. The geometry of the HGUs is defined independently of the model layers, with the model-layer geometry superimposed on the defined HGUs. In the local-scale model, one to three HGUs are present in each active model cell.

The HGUs specified in the local-scale model are shown in figure 15 and table 7 at end of report. HGU1 (overburden) represents a composite unit comprised of the geologic materials that overlie the Edwards aquifer in the local-scale model area. HGU1 ranges in thickness from 0.3 to $759 \mathrm{~m}$, where present, and because it is predominantly a confining unit it was not simulated in the rediscretized regional Edwards aquifer models (Lindgren and others, 2011). HGU1 was included in the local-scale model because of horizontal hydraulic discontinuities between HGUs in some areas near the southern boundary of the recharge zone that result from the effects of large-displacement faults. The displacement of these faults along some segments exceed the aquifer thickness, in some cases lowering the top of the uppermost HGU in one cell below the bottom of the lowermost HGU in an adjacent cell, thereby creating a hydrogeologically undefined vertical interval (hydraulic discontinuity). HGU2 (Georgetown Formation), HGU3 (cyclic and marine members of the Edwards Group), HGU4 (leached and collapsed members of the Edwards Group), HGU6 (regional dense member of the Edwards Group), HGU7 (grainstone member of the Edwards Group), HGU8 (Kirschberg evaporate member of the Edwards Group), HGU10 (dolomitic member of the Edwards Group), and HGU11 (basal nodular member of the Edwards Group) represent the commonly defined stratigraphic units of the Edwards aquifer (Maclay, 1995; fig. 11, p. 26) (fig. 10), with differing lithologic and hydrologic properties. HGU5 and HGU9 are the "conduit" HGUs representing hydrogeologic units with high hydraulic conductivities (one or more orders of magnitude higher than for the other HGUs) intended to simulate fast flow paths attributable to karst features. HGU12 represents the Glen Rose Limestone of the Trinity Group that underlies the Edwards Group and has a relatively small permeability compared to the permeability of the Edwards aquifer. HGU12 was included in the local-scale model to prevent unsaturated or thinly saturated areas from going dry (simulated water level falling below the simulated base of the model layer) in the recharge zone. Part of the underlying, lower permeability Glen Rose Limestone of the Trinity Group was added to the total aquifer thickness in the recharge zone and unconfined areas near the recharge zone.
In the HUF Package, HGUs are defined by the top altitude and thickness of each HGU for each row and column in the model grid. If an HGU does not occur at a row and column location, then the thickness is set to zero. The top altitude for HGU1, where present, was specified as land surface altitude. HGU1 is absent in the recharge zone, where the Edwards aquifer outcrops. HGU7, HGU8, HGU9, HGU10, HGU11, and HGU12 occur at land surface at various locations in the recharge zone, and for model cells in these areas the top altitudes for the appropriate HGUs are specified as land surface altitude. The altitude of the top of the Georgetown Formation (HGU2), the uppermost HGU of the Edwards aquifer, was derived from available drillers' logs in the local-scale model area. The altitudes of the tops of the remaining nine HGUs composing the Edwards Group corresponding to the Edwards aquifer (HGU3, HGU4, HGU5, HGU6, HGU7, HGU8, HGU9, HGU10, and HGU11) and of HGU12 underlying the Edwards aquifer were calculated in a downward progression as the top altitude of the overlying HGU minus the thickness of the overlying HGU. The thicknesses for HGU1 were calculated as the differences between the altitude of the land surface and the altitude of the top of the Georgetown Formation. The thicknesses for the HGUs composing the Edwards aquifer, other than the conduit HGUs (HGU5 and HGU9) representing relatively fast flow paths attributable to karst features, were derived from available drillers' logs in the local-scale model area. Groundwater velocities in the conduit HGUs are likely appreciably greater than average velocities in the other HGUs. Walker (1979) reported that groundwater moving through fractured, jointed, or solutioned rocks [conduits] could move on the order of $100 \mathrm{~m} / \mathrm{d}$ compared to velocities of a meter per year in other parts of the aquifer. Tracer testing in the San Antonio segment of the Edwards aquifer has shown rapid flow (velocities of 179.8 to $800.1 \mathrm{~m} / \mathrm{d}$ over distances of 0.8 to $4.0 \mathrm{~km}$ ) from wells to the nearby high flow springs (Ogden and others, 1986; Rothermel and others, 1987; Schindel and others, 2002). The thicknesses for HGU5 and HGU9 (the conduit HGUs) were initially specified as a uniform $3 \mathrm{~m}$ but were increased to a uniform $8 \mathrm{~m}$ during model calibration. The thicknesses for HGU12 (Glen Rose Limestone member of the Trinity Group corresponding to the Trinity aquifer) were obtained from the rediscretized regional Edwards aquifer models (Lindgren and others, 2011). The maximum thicknesses range from $8 \mathrm{~m}$ for HGU5 and HGU9 to $759 \mathrm{~m}$ for HGU1, with much of the thickness for HGU1 being unsaturated. The maximum thicknesses for the HGUs composing the Edwards aquifer, other than HGU5 and HGU9, range from $12 \mathrm{~m}$ (regional dense member of the Edwards Group corresponding to the Edwards aquifer) to $51 \mathrm{~m}$ (leached and collapsed members of the Edwards Group corresponding to the Edwards aquifer).

Karst features were incorporated into the local-scale model by specifying two comparatively thin ( $8 \mathrm{~m}$ ) HGUs with large horizontal hydraulic conductivities (initial values of $152,393 \mathrm{~m} / \mathrm{d}$ ) and low effective porosities (initial dimensionless values of $\left.1.0 \times 10^{-4}\right)$. The top altitudes and thicknesses for 
$\boldsymbol{A}$

NORTH

Northern boundary

of recharge zone

|

Southern boundary

$\begin{array}{r}\begin{array}{c}\text { Southern boundary } \\ \text { of recharge zone }\end{array} \\ \hline\end{array}$

S

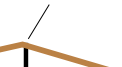

HGU 12

EXPLANATION

Hydrogeologic unit (HGU) and

number-See table 7

HGU 1 HGU other than 5 and 9

HGU 5 HGUs 5 and 9 (conduit HGUs representing

units with a high density of fast flow

paths attributable to karst features)

Open interval

Simulated water-level altitude

Land-surface altitude

I Well

- L Large displacement fault

Figure 15. Generalized hydrogeologic sections and measured and simulated tritium concentrations in the local-scale study area, San Antonio region, Texas.

the conduit HGUs (HGU5 and HGU9) were specified so as to correspond with the lower $8 \mathrm{~m}$ of the leached and collapsed members of the Edwards Group for HGU5 and the lower $8 \mathrm{~m}$ of the Kirschberg evaporite member of the Edwards Group for HGU9. Geophysical logging by the USGS in 2008 (Gregory Stanton, U.S. Geological Survey, written commun., 2008) in the selected PSW and nearby monitoring wells indicated that most of the flow and the greatest transmissivities occurred in the leached and collapsed members of the Edwards Group and the Kirschberg evaporite member of the Edwards Group. The large flows and high estimated transmissivities for these intervals are thought to reflect the presence of fast flow paths and conduit features, and the conduit HGUs were therefore specified for these approximate intervals. Scant information exists regarding hydraulic properties, flow rates, and karst features of the Edwards aquifer HGUs other than the geophysical logging done in 2008 (Gregory Stanton, U.S. Geological Survey, written commun., 2008). Therefore, the results from the selected PSW and nearby monitoring wells were extrapolated throughout the local-scale model area, and the top altitudes and thicknesses for the conduit HGUs (HGU5 and HGU9) were specified so as to correspond with the lower $8 \mathrm{~m}$ of the leached and collapsed members and the Kirschberg evaporite member of the Edwards Group throughout the local-scale model area. The thicknesses of HGU4 (leached and collapsed members of the Edwards Group) and HGU8 (Kirschberg evaporite member of the Edwards Group) were reduced by $8 \mathrm{~m}$ to accommodate the inclusion of the conduit HGUs.

Numerous faults with varying vertical displacements occur in the local-scale model area. The extensive faulting results in the juxtaposition of HGUs with differing hydraulic properties and has appreciable effects on groundwater flow in the Edwards aquifer. As previously discussed in this section, the displacement of faults along some segments exceeds the aquifer thickness, thereby creating a hydrogeologically undefined vertical interval (hydraulic discontinuity) in the local-scale model. Because the local-scale model uses the MODFLOW HUF Package and the geometry of the hydrogeologic units is defined independently of the model layers, different HGUs with differing hydraulic properties are frequently 
B

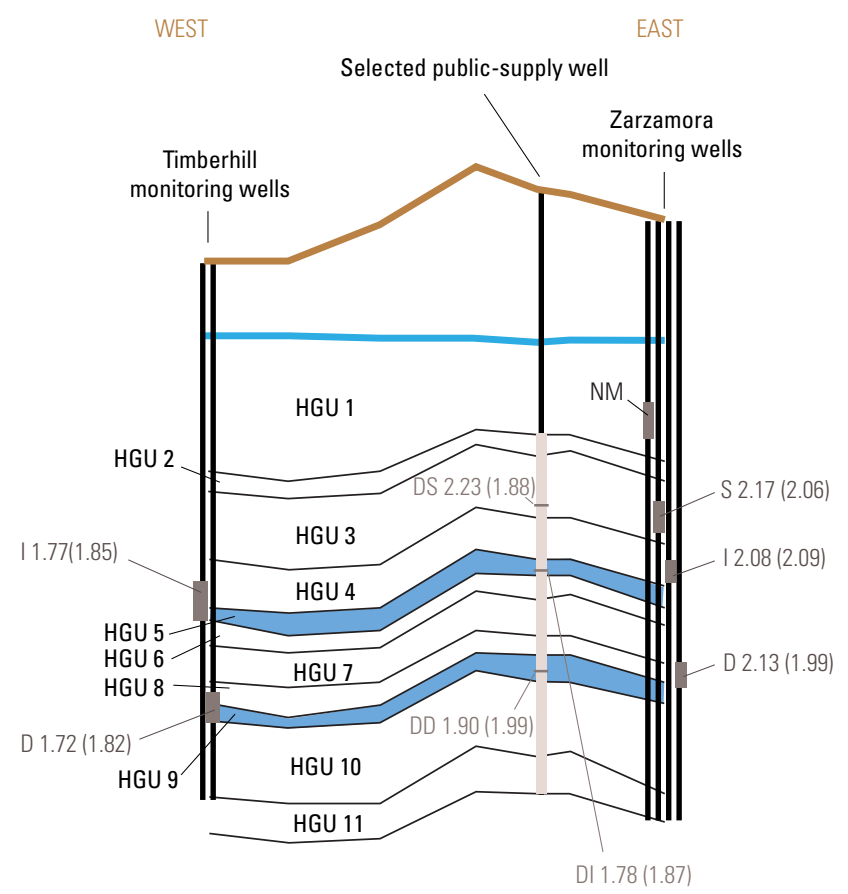

EXPLANATION

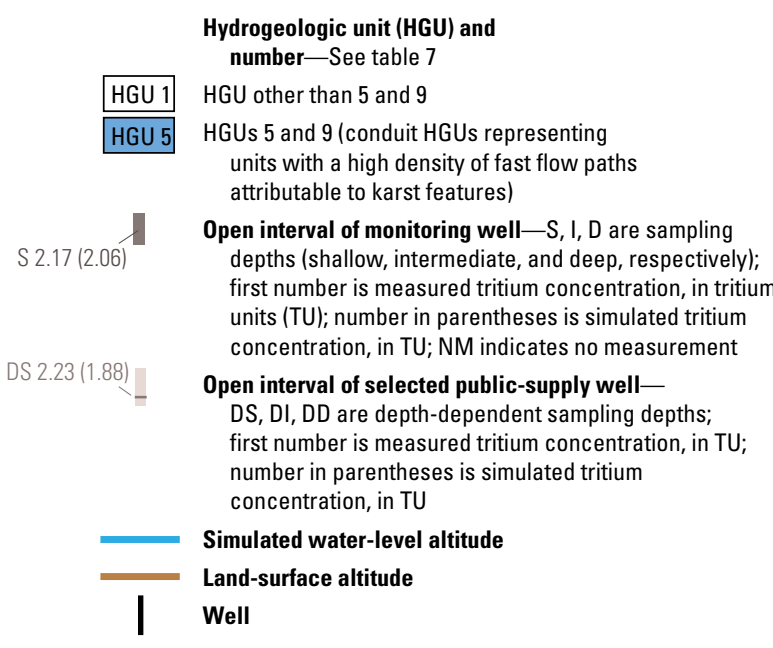

Figure 15. Continued.

juxtaposed in adjacent cells in the local-scale model. This juxtaposition allows water particles to move between HGUs within the same model layer and incorporates the effects of faulting in the model geometry. In contrast, when the HGUs and model layers coincide, water particles are forced to move vertically along a simulated fault interface in order to stay in the same model layer.

The MODFLOW Horizontal-Flow Barrier (HFB) Package (Harbaugh and others, 2000) was used to simulate faults in the local-scale model (fig. 12). Required parameters include the (1) location of the horizontal-flow barrier (fault) and (2) hydraulic characteristic of the horizontal-flow barrier (fault), a measure of conductance across the fault. Horizontalflow barriers were placed at the boundaries of cells crossed by the trace of a fault. Fault locations and fault displacements from the rediscretized regional Edwards aquifer models were revised and updated in the local-scale study area for inclusion in the local-scale model on the basis of current (2009) hydrogeologic and stratigraphic information. The location of a fault is specified by the cell locations for the two cells that the fault separates. The hydraulic characteristic of the fault is an inverse measure of the degree to which it acts as a barrier to flow, defined as the fault hydraulic conductivity divided by its width. When the assigned value for the hydraulic characteristic of the fault is greater, it acts less as a barrier to flow. For the local-scale model, the assumption was made that the degree to which a fault acts as a barrier to groundwater flow is proportional to the fault displacement, with the hydraulic characteristic of the fault being inversely proportional to the fault displacement. Because of the uncertainty of the components (fault hydraulic conductivity and fault width) typically used to compute the hydraulic characteristic, values for the hydraulic characteristic of faults were determined during model calibration. The faults were divided into five categories on the basis of their associated fault displacements and a hydraulic characteristic assigned, with categories of greater fault displacements being assigned lower hydraulic-characteristic values. The initial hydraulic-characteristic values ranged from $1.0 \times$ $10^{-9}$ to 0.02 per day for fault displacements ranging from 0 to more than 100 percent of the total aquifer thickness (fig. 12). The hydraulic-characteristic values were varied during model calibration until the appropriate simulated barrier effect was achieved on the basis of measured water-level altitudes and known effects of faults on groundwater-flow directions.

\section{Boundary Conditions and Model Stresses}

Boundary conditions for the local-scale model include specified fluxes entering or exiting the model area at the boundaries, and stresses include recharge from precipitation, discharge from pumping, and discharge to springs. In the local-scale model, specified fluxes are used for boundary conditions on all sides and layers of the model, except for layers that are inactive at the model boundary or whose thickness includes only HGU1. Water flowing across the boundary into HGU1 is assumed to be negligible. Average stresses (recharge and pumpage) during 2001, a representative year for the recent time period (2000-10), were used to simulate steady-state conditions.

\section{Lateral Boundaries}

The local-scale model employs lateral nonzero fluxes across boundaries so that the model extent does not have to include the natural hydrologic groundwater divides, thus allowing the focus of the modeling effort to remain on the ACR of the selected PSW. The nonzero fluxes are specified by 
using the MODFLOW Well Package (Harbaugh and others, 2000). The northern boundary of the active local-scale model corresponds with the physical limits of the Edwards aquifer, more specifically with the northern limit of the Edwards aquifer recharge zone (fig. 4). A nonzero flux boundary was used for the northern model boundary to account for inflow from the adjacent Trinity aquifer. The fluxes from the two-layer diffuse-flow rediscretized regional Edwards aquifer model were apportioned among the 92 layers of the local-scale model on the basis of the cumulative transmissivities of the HGUs present in each boundary cell. Therefore, the highest fluxes in a vertical sequence of model layers for a given (row, column) grid location occur in the layers that contain the HGUs with the highest simulated transmissivities (horizontal hydraulic conductivity times thickness).

All specified nonzero boundary fluxes for the western, southern, and eastern boundaries of the local-scale model were derived from the two-layer diffuse-flow rediscretized regional Edwards aquifer model. The simulated fluxes from the diffuse-flow rediscretized regional Edwards aquifer model were used in the local-scale model, rather than from the conduit-flow rediscretized regional Edwards aquifer model, because of the dominant effect of the simulated conduits on simulated groundwater flow in the conduit-flow rediscretized regional Edwards aquifer model (Lindgren and others, 2011). The distribution of simulated fluxes into the local-scale model area is proportional to the simulated hydraulic conductivity in each model cell of the conduit-flow rediscretized regional Edwards aquifer model corresponding to model boundary cells in the local-scale model. Therefore, a comparatively high proportion of the boundary flux into the local-scale model area occurs through model cells of the conduit-flow rediscretized regional Edwards aquifer model that coincide with simulated conduit cells (Lindgren and others, 2011, fig. 9A). The simulated conduits in the conduit-flow rediscretized regional Edwards aquifer model are one cell wide and have assigned hydraulic conductivity values two to five orders of magnitude greater than the assigned hydraulic conductivity values for the nonconduit model cells. Similarly, for the diffuse-flow rediscretized regional Edwards aquifer model, a comparatively high proportion of the boundary flux into the local-scale model area occurs through cells that coincide with simulated high hydraulic conductivity zones (Lindgren and others, 2011, fig. 9B). The simulated high hydraulic conductivity zones in the diffuse-flow rediscretized regional Edwards aquifer model reduce the effects of uncertainty regarding the locations of conduits in the Edwards aquifer and spread the distribution of comparatively high boundary fluxes over the lateral extent.

The simulated fluxes from the diffuse-flow rediscretized regional Edwards aquifer model include flows into and out of the local-scale model area for all three model boundaries. The net boundary flux for the western local-scale model boundary is into the local-scale model area $(986,034$ cubic meters per day $\left[\mathrm{m}^{3} / \mathrm{d}\right]$ ), while the net boundary fluxes for the eastern and southern local-scale model boundaries are out of the local-scale model area $\left(782,013\right.$ and $327,430 \mathrm{~m}^{3} / \mathrm{d}$, respectively) (table 8 at end of report). About 79 percent of the inflow through the western local-scale model boundary occurs through the boundary cells coinciding with the simulated high hydraulic conductivity zones through the center of the confined part of the aquifer and near the northern boundary of the freshwater/saline-water transition zone (HK zones 14 and 17) (fig. 16). Similarly, about 97 percent of the outflow through the eastern local-scale model boundary occurs through the boundary cells coinciding with the simulated high hydraulic conductivity zones in the southeastern part of the local-scale model area (HK zones 13, 16, and 17) (fig. 16).

For the western, southern, and eastern boundaries of the local-scale model, the fluxes from the two-layer diffuse-flow rediscretized regional Edwards aquifer model were apportioned among the 92 layers of the local-scale model based on the cumulative transmissivities of the HGUs present in each boundary cell. Therefore, the highest fluxes in a vertical sequence of model layers for a given (row, column) grid location occur in the layers that contain the HGUs with the highest simulated transmissivities. Because the simulated conduit HGUs have assigned horizontal hydraulic conductivities that are at least an order of magnitude higher than for the other HGUs, the highest fluxes in a vertical sequence of model layers for a given (row, column) grid location occur in the layers that contain the conduit HGUs.

\section{Recharge}

Recharge to the Edwards aquifer occurs primarily by seepage from streams to the aquifer in the recharge zone (fig. 3). Additional recharge is from infiltration of rainfall in the interstream areas of the recharge zone. Recharge in the local-scale model by seepage from streams and infiltration of rainfall was assigned to nine streams (Hondo Creek, Verde Creek, Quihi Creek, Medina River, San Geronimo Creek, Culebra Creek, Helotes Creek, Leon Creek, and Salado Creek) and their interstream areas for three recharge subzones in the recharge zone (fig. 4) on the basis of monthly recharge rates to the Edwards aquifer for 2001 computed by the USGS and published, as annual totals, by the EAA (Hamilton and others, 2003). The three recharge subzones in the local-scale model area are the area between the Sabinal and Medina Rivers, the Medina River, and the area between the Medina River and Cibolo-Dry Comal Creek (fig. 4). Monthly and annual (2001) recharge rates for the recharge subzones simulated in the local-scale model are shown in table 4 . As for the rediscretized regional Edwards aquifer models (Lindgren and others, 2011), 85 percent of the recharge was applied to streambed cells, and the remaining 15 percent was applied to the interstream area cells in the local-scale model, on the basis of percentages reported in the literature. A specified-flux boundary, simulated by using the MODFLOW Recharge Package (Harbaugh and others, 2000), was used to represent recharge to the aquifer in the recharge zone. No recharge was applied to cells outside the recharge zone. 


\section{EXPLANATION}

Local-scale study area-Includes active local-scale model area and a portion of inactive local-scale model area (fig. 4)

Active local-scale model area-Horizontal hydraulic conductivity (HK) zone number and calibrated $\mathrm{HK}$ value, in meters per day (table 9)

(1) Base HK, varies by hydrogeologic unit (table 9 )

HK13 $=6,584$

HK14 $=4,073$

HK15 $=5,863$

HK16 $=5,227$

HK17 $=4,297$

$\mathrm{HK} 18=0.35$

$\mathrm{HK} 19=2.56$

$\mathrm{HK} 20=2.50$

HK21 $=1.59$

$\mathrm{HK} 22=2.18$

$\mathrm{HK} 23=17.3$

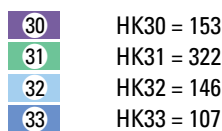

Inactive local-scale model area

- Urban area boundary

Local-scale study area boundary

Edwards aquifer recharge zone (outcrop) boundary (modified from Puente, 1978)

Freshwater/saline-water interface $\mathbf{1 , 0 0 0}$ milligrams per liter dissolved solids concentration) (A.L. Schultz, consultant, written commun., 2000)

no Spring

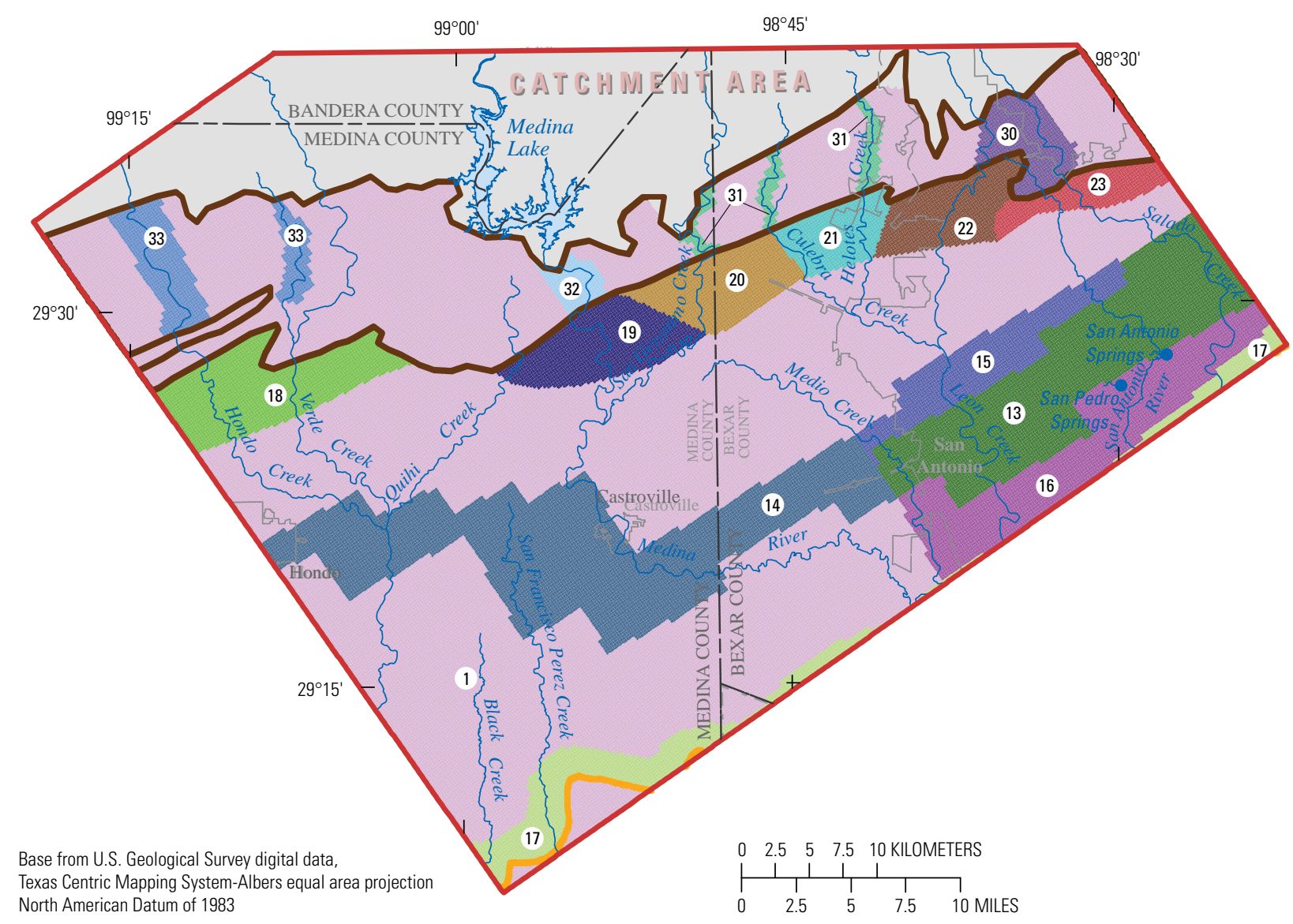

Figure 16. Distribution of calibrated horizontal hydraulic conductivity in hydrogeologic units $2-4,6-8$, and $10-11$ in the local-scale model, San Antonio region, Texas. 


\section{Discharge}

Discharge from the Edwards aquifer includes withdrawals by wells and springflow. Average withdrawal rates by wells for 2001 were the same for both of the rediscretized regional Edwards aquifer models (conduit-flow and diffuseflow models), and these rates were distributed spatially within the model grid for the local-scale model, on the basis of the well locations. The vertical assignment of withdrawals to a model layer was done on the basis of the percentage of the screened interval in each of the model layers and the transmissivity of the HGUs present in each model layer. Withdrawals were separated into four categories according to water use: municipal, industrial (includes manufacturing, mining, and power generation), irrigation, and livestock (table 5). Municipal withdrawals were provided (1) by well by EAA (Edwards Aquifer Authority, 2009) and Bexar Metropolitan Water District and (2) for each of their well fields by SAWS (San Antonio Water System, 2008). Industrial, irrigation, and livestock withdrawals were provided by well by EAA (Edwards Aquifer Authority, 2009) for most of the model area, but in some areas irrigation withdrawals were spatially distributed for the landuse categories of row crops, small grains, and orchards/vineyards. Groundwater withdrawals were simulated by using the MODFLOW Well Package (Harbaugh and others, 2000).

Discharge from the Edwards aquifer also includes springflow. San Antonio and San Pedro Springs (fig. 3) were simulated in the local-scale model and used during model calibration in addition to water-level information. The springs were simulated in the model by using the MODFLOW Drain Package (Harbaugh and others, 2000). The MODFLOW Drain Package simulates the effects of features that remove water from the aquifer at a rate proportional to (1) the difference between the water level in the aquifer and the drain elevation and (2) the hydraulic conductance. The hydraulic conductance depends on the characteristics of the convergent flow pattern toward the drain, as well as on the characteristics of the drain itself and its immediate environment (Harbaugh and others, 2000). The initial drain hydraulic conductances specified in the local-scale model were the same as those used in the conduit-flow and diffuse-flow rediscretized regional Edwards aquifer models (Lindgren and others, 2011) (drain hydraulic conductances have the same values in both regional models). The initial drain hydraulic conductances for San Antonio and San Pedro Springs were 613,100 and 3,066 $\mathrm{m}^{2} / \mathrm{d}$, respectively. The drain hydraulic conductances were adjusted during model calibration for the local-scale model to match the mean measured values of discharge during 2001 for San Antonio and San Pedro Springs to simulated values.

\section{Hydraulic Properties}

The aquifer hydraulic properties specified in the localscale model - horizontal hydraulic conductivity and horizontal and vertical anisotropy-were defined by using the MODFLOW HUF Package (Anderman and Hill, 2000). The
MODFLOW HUF Package determines the units that apply to each model layer for each row and column and calculates model-layer horizontal and vertical conductances internally. Characteristics for the model grid are obtained by averaging and by using the assumption that the HGUs that occur within each model finite-difference cell are virtually horizontal.

HGUs that pinch out and are discontinuous are defined by specifying the top altitude and thickness of HGUs, on the basis of defined rows and columns of the finite-difference grid. Hydraulic properties are assigned to the HGUs, rather than to the model layers, by using parameters (Harbaugh and others, 2000, p. 12).

Areal distributions of horizontal hydraulic conductivities for the simulated HGUs in the local-scale model are shown in figures 16 and 17. The simulated horizontal hydraulic conductivities include a base value that varies by HGU (zone 1 in figures 16 and 17) and additional zones and values that are the same for multiple HGUs (figs. 16 and 17). The initial base horizontal hydraulic conductivity for each simulated HGU (HK1-HK12 corresponding to HGU1-HGU12) is shown in table 9 at end of report. The initial base horizontal hydraulic conductivities were based on reported horizontal hydraulic conductivities for the Edwards aquifer (table 3 ) and the relative permeabilities by Maclay (1995; fig. 11, p. 26) for the eight hydrogeologic units of the Edwards aquifer (I-VIII on fig. 10). The highest permeabilities in Maclay (1995; fig. 11, p. 26) are for the cyclic and marine members and the leached and collapsed members of the Edwards Group and for the Kirschberg evaporite member of the Edwards Group. These high permeabilities are consistent with the results of geophysical logging conducted by the USGS in 2008 (Gregory Stanton, U.S. Geological Survey, written commun., 2008) in the selected PSW and nearby monitoring wells, which indicated that most of the flow and the greatest transmissivities occurred in the leached and collapsed members of the Edwards Group and the Kirschberg evaporite member of the Edwards Group. The base horizontal hydraulic conductivities were adjusted during model calibration for the local-scale model to match the measured water-level altitudes and spring discharges during 2001 and measured tritium concentrations to simulated values.

In addition to the base horizontal hydraulic conductivity for each of the 12 simulated HGUs, with the exception of HGU1 and HGU12 there are zones of horizontal hydraulic conductivity with assigned values that differ from the base value for each HGU (figs. 16 and 17). The appropriate base horizontal hydraulic conductivity value is used for the full extent of HGU1 (HK1) and HGU12 (HK12). Horizontal hydraulic conductivity zones, in addition to the base horizontal hydraulic conductivity zone (zone 1), include (1) zones of high horizontal hydraulic conductivity through the center of the confined part of the aquifer and near the northern boundary of the freshwater/saline-water transition zone (hereinafter, the "high-K confined zones") (fig. 16; zones 13-17), (2) zones of comparatively high horizontal hydraulic conductivity in the recharge zone underlying streambeds (hereinafter, 


\section{EXPLANATION}
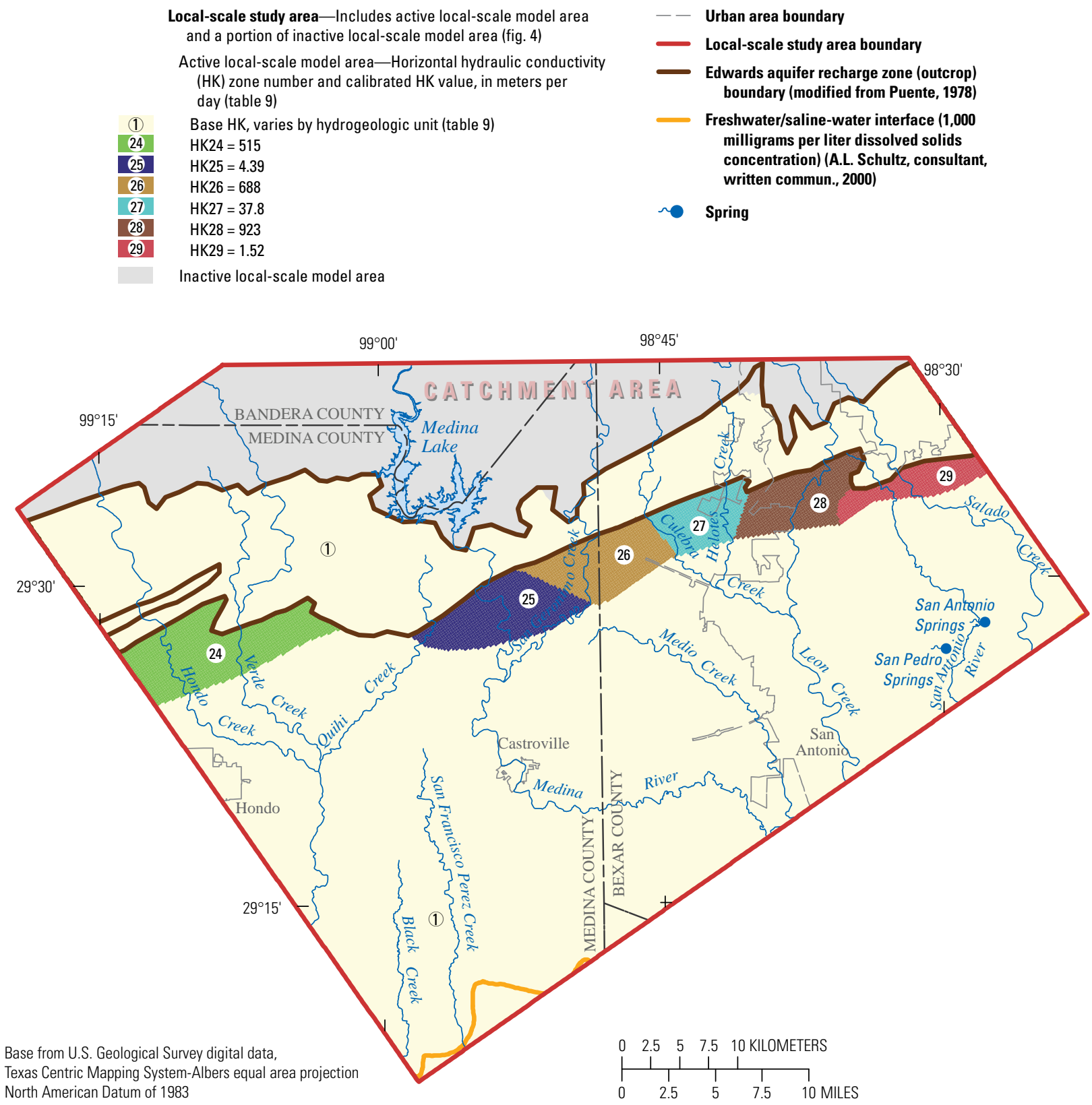

Figure 17. Distribution of calibrated horizontal hydraulic conductivity in hydrogeologic units 5 and 9 in the local-scale model, San Antonio region, Texas.

the "high-K streambed zones") (fig. 16; zones 30-33), and (3) zones of differing horizontal hydraulic conductivity near the boundary between the recharge zone and the confined part of the Edwards aquifer (hereinafter, the "K transition zones") (fig. 16; zones 18-23) (fig. 17; zones 24-29). The high-K confined zones simulated in the local-scale model are derived from zones of high horizontal hydraulic conductivity used in the diffuse-flow rediscretized regional Edwards aquifer model (Lindgren and others, 2011), with minor modifications. The high-K confined zones (fig. 16; zones 13-17) are simulated for all of the HGUs, except for the two conduit HGUs (HGU5 and HGU9) and HGU1 and HGU12 (table 9) and extend through much of the aquifer thickness. The high-K streambed zones are similarly derived from zones of high horizontal hydraulic conductivity underlying streambeds used in the conduit-flow and diffuse-flow rediscretized regional Edwards aquifer models (Lindgren and others, 2011) (zones are the same in both regional models), with minor modifications. The high-K streambed zones (fig. 16; zones 30-33) are simulated for the same HGUs as are the high-K confined zones and also 
are simulated for HGU12 (table 9). The simulated horizontal hydraulic conductivities for the high-K confined zones and the high-K streambed zones were varied during model calibration to match the measured water-level altitudes and spring discharges during 2001 and the measured tritium concentrations to simulated values.

The $\mathrm{K}$ transition zones have one set of values for all the HGUs, except the two conduit HGUs (HGU5 and HGU9) and HGU1 and HGU12 (fig. 16). A different set of values is used for the conduit HGUs (HGU5 and HGU9) (fig. 17). However, the extent of each zone is the same for all the HGUs for which they are used (figs. 16-17). The $\mathrm{K}$ transition zones (figs. 16-17; zones 18-29) have initial horizontal hydraulic conductivities that are equal to or less than the base horizontal hydraulic conductivities of the HGUs for which they are used and tend to retard flow and maintain higher simulated water-level altitudes near the boundary between the recharge zone and the confined part of the Edwards aquifer (table 9).

$\mathrm{K}$ transition zones 27 and 28 were assigned initial horizontal hydraulic conductivities (parameters HK27 and HK28) that were an order of magnitude higher than the initial horizontal hydraulic conductivities of the other $\mathrm{K}$ transition zones (but still much lower than the base horizontal hydraulic conductivities for HGU5 and HGU9). K transition zones 27 and 28 thereby potentially serve as areas of preferential, fast flow paths near the boundary between the recharge zone and the confined part of the Edwards aquifer. The simulated horizontal hydraulic conductivities for the $\mathrm{K}$ transition zones were varied during model calibration to match the measured water-level altitudes and spring discharges during 2001 and measured tritium concentrations to simulated values.

Six zones of horizontal anisotropy are simulated in the local-scale model (fig. 18, table 9). The confined part of the Edwards aquifer composes one of the horizontal anisotropy zones (zone 1), and the remaining five zones are delineated in the recharge zone of the aquifer. Maclay and Land (1988) hypothesized that large-displacement faults segment the aquifer and divert flow entering the recharge zone on relay ramps (transfer zone accommodating deformation between normal fault segments with similar dip directions [Peacock and Sanderson, 1994]) to the west before flow is redirected toward the east. Clark and Journey (2006) indicated that relay ramps and associated faulting in and near the recharge zone in Medina County appear to channel groundwater flow along flow paths that move water toward the southwest, rather than directly down the formational dip from the recharge zone into the confined zone of the aquifer. Similar relay ramps and associated faulting likely are present in the recharge zone in Bexar County, but the fault displacements in the recharge zone in Bexar County are appreciably smaller compared to those in Medina County. Because of the departure from downdip flow demonstrated by Clark and Journey (2006), an initial value of 0.1 was specified for horizontal anisotropy for zone 2 in the recharge zone in Medina County in the western part of the model area (fig. 18, table 9). An initial value of 1.0 was specified for horizontal anisotropy for the other five zones, the same as was used in the rediscretized regional Edwards aquifer models (Lindgren and others, 2011). Multiple horizontal anisotropy zones were specified in the recharge zone to allow for variations in horizontal anisotropy between the western and eastern parts of the recharge zone and between selected high-K streambed zones to potentially better match measured water-level altitudes. The simulated horizontal anisotropy values were varied during model calibration to match the measured water-level altitudes and spring discharges during 2001 and measured tritium concentrations to simulated values.

Uniform vertical anisotropy parameters were applied to each of the 12 simulated HGUs (table 9). An initial value of 10 was specified for the more permeable HGUs (initial horizontal hydraulic conductivities greater than or equal to $91 \mathrm{~m} / \mathrm{d}$ ), while an initial value of 0.1 was specified for the less permeable HGUs (initial horizontal hydraulic conductivities less than or equal to $3.0 \mathrm{~m} / \mathrm{d}$ ) (table 9). Freeze and Cherry (1979) indicated that it is not uncommon for layered heterogeneity to lead to regional vertical anisotropy values on the order of 100:1 or larger. However, Snow (1969) showed that fractured rocks may behave anisotropically because of the directional variations in joint aperture and spacing, and, in this case, it is quite common for vertical hydraulic conductivity to be greater than horizontal hydraulic conductivity. Fractures are common throughout the entire thickness of the Edwards aquifer and commonly cross several strata (Maclay and Land, 1988). These fractures are believed to hydraulically interconnect the permeable strata (Maclay and Land, 1988). Abundant fractures adjacent to faults are well connected both laterally and vertically by numerous intersecting and crosscutting fractures (Hovorka and others, 1998). In the karstic, highly faulted Edwards aquifer, fractures, faults, and karst features might contribute to vertical hydraulic conductivity being greater than horizontal hydraulic conductivity. The simulated vertical anisotropy values were varied during model calibration to match the measured water-level altitudes and spring discharges during 2001 and measured tritium concentrations to simulated values.

\section{Particle-Tracking Simulations}

Particle tracking was used to compute flow paths and advective traveltimes throughout the model area and to delineate the ACR and zones of contribution (ZOCs) for the selected PSW and the two monitoring well nests. The ACR to a discharging well is defined as the area at the water table where recharging water that enters the groundwater-flow system will eventually be removed by the well. The ZOC is defined as the specific volume of aquifer material bounded by outermost flow paths that will recharge a discharging well (Focazio and others, 2002). Steady-state conditions were assumed and the volume of water associated with individual particles of water entering the well were estimated on the basis of the simulated distribution of recharge. The recharge volumes were combined with estimated input concentrations of the age-tracer tritium on the basis of the simulated particle 


\section{EXPLANATION}
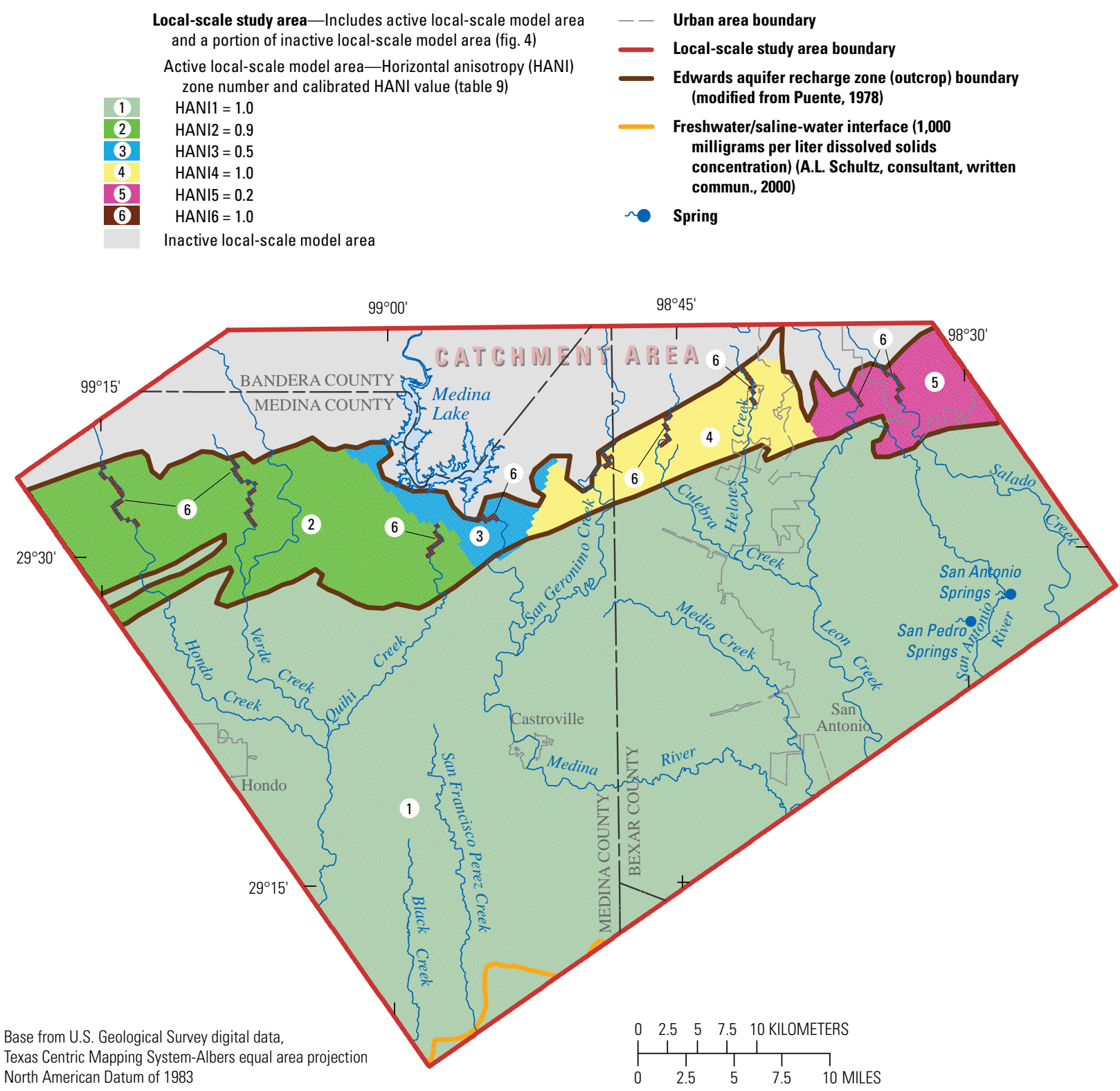

Figure 18. Distribution of calibrated horizontal anisotropy in the local-scale model, San Antonio region, Texas.

traveltimes to calculate flux-weighted concentrations of the tracer reaching the well. The resulting calculated concentrations were compared with measured concentrations to evaluate the adequacy of the model to simulate traveltimes and flow paths for potential contaminants.

Particle tracking was performed by using MODPATH, which uses cellular volumetric fluxes from a groundwaterflow model and effective porosity to calculate linear velocity (Pollock, 1994). The $\mathrm{x}, \mathrm{y}$, and $\mathrm{z}$ components of linear velocity are used to generate a velocity field by using simple linear interpolation of the components between adjacent cell faces of the finite-difference cells. For steady-state simulations, an analytical expression for the flow path in each cell is calculated by direct integration of the velocity components. The traveltime calculated by this method represents an average traveltime for the advection of a "particle" of water or a conservative solute. Dispersion, diffusion, adsorption, retardation, degradation, or any other transport process affecting the concentrations of contaminant constituents is not included in the MODPATH simulation for determining traveltimes of water. The simulated ages of water particles at a well are computed by tracing water particles either backward from the well toward the ACR or forward from the ACR to the open-interval of the well. 
Along with output from the groundwater-flow model, MODPATH simulations require effective porosity values to calculate groundwater-flow velocities. Initial effective porosity values in the local-scale model were based on values reported in Hovorka and others (1996), Kuniansky and others (2001), and Crandall and others (2009). Uniform effective porosity values ranging from 0.0001 to 0.01 were specified for each of the 12 HGUs (table 10 at end of report). An initial value of 0.01 was specified for the HGUs with comparatively high hydraulic conductivities (HGU3, HGU4, HGU7, HGU8, and HGU10), other than the two conduit HGUs. An initial value of 0.001 was specified for the HGUs with comparatively low hydraulic conductivities (HGU1, HGU2, HGU6, HGU11, and HGU12). The lowest initial value, 0.0001 , was assigned to the two conduit HGUs (HGU5 and HGU9). The initial value for the HGUs with comparatively high hydraulic conductivities is similar to the values reported by Kuniansky and others (2001) that were needed for the karstic Edwards aquifer system in Texas to match estimated traveltimes derived from geochemical mixing models. The initial value for the two conduit HGUs is similar to the value used by Crandall and others (2009) to represent karstic model layers containing preferential flow path or conduit features. The initial effective porosity values were varied during model calibration by using the measured age-tracer (tritium) concentrations at the monitoring wells and the selected PSW as observations in the nonlinear estimation by using PEST.

In a steady-state model, changes to input porosity values do not change the area contributing recharge to a given well. Changes to input porosity values, however, will change computed traveltimes from recharge areas to discharge areas (PSWs) in direct proportion to changes of effective porosity because there is an inverse linear relation between groundwater flow velocity and effective porosity and a direct linear relation between traveltime and effective porosity (Heath, 1983, p. 25). For example, a 1-percent decrease in porosity will result in a 1-percent increase in velocity and a 1-percent decrease in particle traveltime.

To calculate concentrations of the age-tracer tritium at the selected PSW and monitoring wells for parameter estimation, particle tracking was used to obtain a distribution of particle ages that were then associated with a local tritium input function (biannual historical concentrations of tritium in the atmosphere). Backward tracking was used in MODPATH to obtain the age distributions. MODPATH particle-tracking simulations were conducted for the selected PSW for "normal" pumping conditions (selected PSW and nearby PSWs in the well field pumping), five monitoring wells (Timberhill and Zarzamora), and four PSWs. For the monitoring wells, 250 particles for each model layer were evenly distributed in a vertical line over the open interval of each monitoring well. Particles were tracked backward toward the ACR. For the PSWs, 1,000 particles, vertically distributed on each cell face over the open interval of the well based on the simulated flows to the well, were tracked using the backward particle tracking mode. Each particle is associated with an end point and total traveltime, a flow pathline, and traveltime along the flow pathline. In addition, the ACR and the ZOC are mapped from the resultant collection of flow pathlines for the selected PSW and monitoring wells. Comparisons between mean simulated particle ages and interpreted (apparent) groundwater ages are discussed later in the report in the section "Simulated Zones of Contribution, Areas Contributing Recharge, and Water Particle Ages."

\section{Model Calibration}

The local-scale model was calibrated for steady-state conditions. Average stresses (recharge and pumpage) during 2001, a representative year for the recent time period (200010 ), were used to simulate steady-state conditions. The overall goodness of fit of the local-scale model to the observation data can be evaluated by using summary statistics and graphical analyses. The goodness of fit between simulated and measured water-level altitudes, simulated and measured springflows, and simulated and measured tritium concentrations was quantified by using the mean absolute difference, mean algebraic difference, and root mean square (RMS) error. The mean absolute difference is the sum of the absolute values of the differences divided by the number of observations. The mean algebraic difference is the algebraic sum of the differences divided by the number of observations. The RMS error is derived from the differences between the simulated and measured hydraulic heads, as given in Lindgren and others (2004, p. 63, equation 2 ). If the ratio of the RMS error to the total head change in the modeled area is small, then the error in the head calculations is a small part of the overall model response (Anderson and Woessner, 1992).

Groundwater-flow-model and particle-tracking calibration was evaluated by using 84 groundwater-level altitudes and 13 tritium concentrations. Overall, 70 parameters were used to define the simulation, including those for horizontal hydraulic conductivity, horizontal and vertical anisotropy, drain hydraulic conductance, fault hydraulic conductance, and effective porosity. The local-scale model was calibrated by using systematic manual calibration and by using PEST (Doherty, 2005), a universal code for sensitivity, calibration (using parameter estimation), and predictive analysis in concert with MODFLOW-2000 (Harbaugh and others, 2000) and MODPATH (Pollock, 1994). Estimated parameter values minimize the sum of squared differences (residuals) between observed and simulated values (objective function) to result in the best match between measured and simulated water-level altitudes, drain (spring) discharges, and age-tracer (tritium) concentrations. A uniform weight of 1.0 was applied to the water-level observations because the measurement error and reliability of all of the measurements was assumed to be similar. A uniform weight of 10 was applied to the tritium concentration observations when included in conjunction with water-level observations in PEST simulations in order to make the weighted concentration residuals similar in magnitude to the water-level residuals. The PEST simulations were hampered by insensitivity of some parameters (lack of critical 
observations) and significant correlation between parameters. In addition, the PEST simulations including effective porosities as parameters to be estimated resulted in higher residuals (differences between measured and simulated values) for both hydraulic heads and tritium concentrations than did PEST simulations without effective porosities as parameters to be estimated. Therefore, hydraulic properties and drain and fault hydraulic conductances were estimated first by using systematic manual calibration and PEST simulations, and effective porosities were then estimated by using PEST simulations including only effective porosities as parameters to be estimated (all other parameters held constant).

The mean absolute residual for the water-level measurements is $4.2 \mathrm{~m}$ and for tritium concentrations is 0.11 tritium units (TU). There was a mean algebraic difference of $1.9 \mathrm{~m}$ for water-level altitudes, with simulated water-level altitudes being lower than measured water-level altitudes. There was less than a 0.0001 percent discrepancy in the overall water budget. Measured and simulated age-tracer (tritium) concentrations matched well enough to indicate a reasonably good representation of the porosity and hydraulic parameters. Water-level altitudes, spring discharges, and tritium concentrations were used in the calibration of the local-scale model. Measured and simulated water-level altitudes, spring discharges, and tritium concentrations are discussed in detail later in the report in the Water-Level Altitudes, Spring Discharge, and Age-Tracer Concentrations sections, respectively.

\section{Parameter Sensitivity}

As described in Haugh (2006, p. 50), "Composite scaled sensitivities [unitless values scaled from 0 to 100] can be used to compare the importance of different parameters to the calculation of model-simulated water levels and flows (Hill, 1998). Parameters with greater composite sensitivities have greater importance and greater influence on the model solution." The parameters (1) vertical anisotropy for HGU2, HGU5, HGU9, and HGU11, (2) horizontal anisotropy for HANI zone 5, and (3) horizontal hydraulic conductivity for HK zones 15 and 17, with composite sensitivities greater than 70 , are the most sensitive parameters in the simulation compared to those with composite sensitivities less than 70 (fig. 19). The composite sensitivities cited here and shown in figure 19 apply to a mixture of observations and parameters with differing units of measure; therefore, there is no particular unit of measure for the PEST-computed composite sensitivities. The units of the composite sensitivities computed by PEST are specific to the observations and parameters for which sensitivities are calculated (Doherty, 2005). Other sensitive parameters are (1) base horizontal hydraulic conductivity for HGU6, HGU8, HGU9, and HGU10, (2) horizontal hydraulic conductivity for HK zones 21, 23, and 33, and (3) vertical anisotropy for HGU10 at between 50 and 70. Parameters with composite sensitivities equal to or less than 10 are effective porosities for all HGUs other than HGU9. The composite sensitivities for the remaining parameters are between 10 and 50. The composite sensitivities for the effective porosity parameters are small for the PEST simulations with both water level and tritium concentration observations because effective porosity has no effect on simulated water-level altitudes. However, simulated tritium concentrations are sensitive to effective porosity values. The number and location of observations used in the model calibration affect parameter sensitivities and directly control how well parameters can be estimated by using parameter estimation (Doherty, 2005).

\section{Parameter Adjustments}

The aquifer hydraulic properties specified in the localscale model — horizontal hydraulic conductivity and horizontal and vertical anisotropy - were varied during model calibration by using systematic manual calibration and PEST simulations to minimize the difference between model-computed and measured water-level altitudes, spring discharges, and age-tracer (tritium) concentrations. The initial and calibrated values for the model parameters are shown in tables 9 and 10 .

The calibrated base horizontal hydraulic conductivity values were generally similar to the corresponding initial values (table 9). The largest changes were (1) an increase in the horizontal hydraulic conductivities for the cyclic and marine members (HGU3, HK3), the leached and collapsed members (HGU4, HK4), and the Kirschberg evaporite member (HGU8, HK8) of the Edwards Group corresponding to the Edwards aquifer and (2) a decrease in the horizontal hydraulic conductivities for the lower high-K (conduit) unit (HGU9, HK9) and the dolomitic member of the Edwards Group (HGU10, HK10). The calibrated horizontal hydraulic conductivity values for the high-K confined zones (fig. 16; zones 13-17) and high-K streambed zones (fig. 16; zones 30-33) were generally similar to the corresponding initial values, except for high-K streambed zone 31 , which increased from 152 to $322 \mathrm{~m} / \mathrm{d}$ (HK31 in table 9). For the $\mathrm{K}$ transition zones, the largest changes were an increase in the horizontal hydraulic conductivities for the calibrated horizontal hydraulic conductivity values associated with zones 24, 26, and 28 (HK24, HK26, and HK28 in table 9), which are superimposed on the base hydraulic conductivities of HGUs 5 and 9 (fig. 17), the conduit HGUs in the local-scale model representing relatively fast flow paths attributable to karst features (fig. 15A, fig 15B). The calibrated values for these parameters, however, are still three orders of magnitude lower than the calibrated horizontal hydraulic conductivity values for the conduit HGUs. The calibrated horizontal hydraulic conductivity for parameter HK23 also increased appreciably compared to the initial value and is greater than the calibrated base horizontal hydraulic conductivities for HGU2, HGU6, HGU10, and HGU11 (table 9). The increases indicate that these zones might be areas of preferential, fast flow paths near the boundary between the recharge zone and the confined part of the Edwards aquifer.

The calibrated values for horizontal and vertical anisotropy in many cases differed appreciably from the initial values (table 9). The calibrated values for HANI3 and HANI5 were 


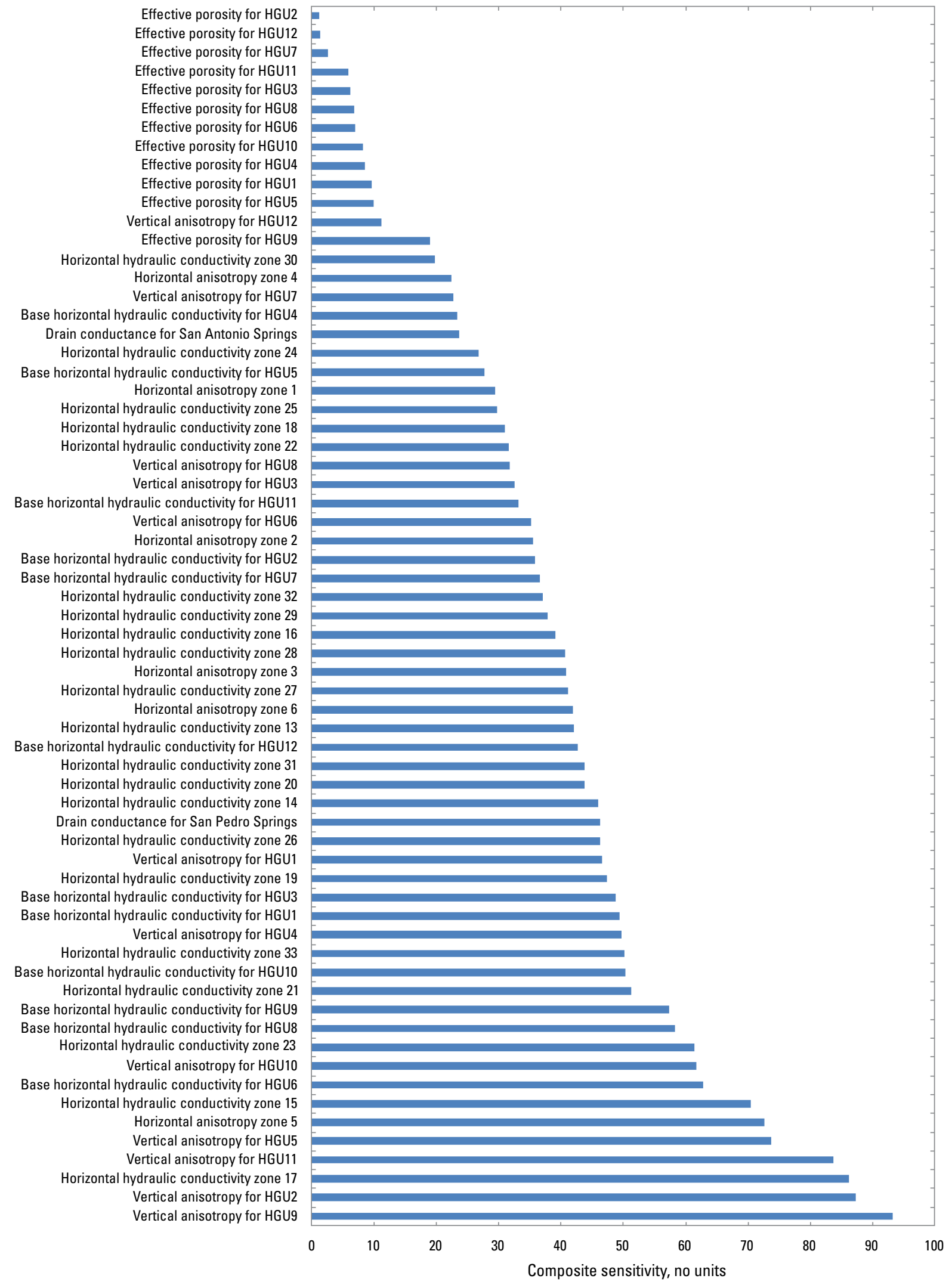

Figure 19. Composite sensitivity of the parameters used to calibrate the local-scale model, San Antonio region, Texas. 
less than the initial values by factors of 2 and 5 , respectively, while the calibrated value for HANI2, in the western part of the recharge zone (fig. 18), increased from 0.1 to 0.9 . The calibrated values for 5 of the 12 vertical anisotropy parameters were similar to the initial values (table 9). The calibrated values for vertical anisotropy parameters VANI2, VANI6, VANI9, and VANI11 increased by a factor of 2 or more compared to the initial values, and for VANI4, VANI7, and VANI10 decreased by a factor of 2 or more. The grainstone member (HGU7, VANI7) and dolomitic member (HGU10, VANI10) of the Edwards Group were changed from an initial vertical anisotropy value of 10 to calibrated values of less than 1.0. Conversely, the basal nodular member (HGU11, VANI11) of the Edwards Group was changed from an initial vertical anisotropy value of 0.1 to a calibrated value of 5.0 (table 9).

The drain hydraulic conductances were adjusted during the steady-state calibration to match measured springflows to simulated springflows. As a result of the steady-state calibration, the drain hydraulic conductance for San Antonio Springs (DR1) was decreased by about 26 percent, and the drain hydraulic conductance for San Pedro Springs (DR2) was increased by about 55 percent (table 10).

The hydraulic conductances for the simulated faults were adjusted uniformly by vertical displacement category during model calibration to match measured water-level altitudes to simulated water-level altitudes. The final calibrated hydraulicconductance values ranged from 0.01 to 0.2 per day (table 10) for fault displacements ranging from 0 to more than 100 percent of the total aquifer thickness. The hydraulic conductances for HFB1, HFB2, and HFB3 were reduced by four to seven orders of magnitude compared to the initial values (table 10), which were based on the values from the rediscretized regional Edwards aquifer models (Lindgren and others, 2011). The use of the HUF Package in the local-scale model and the resulting juxtaposition of HGUs with differing horizontal hydraulic conductivity values in the same model layer might impede flow where HGUs with appreciably different horizontal hydraulic conductivities are juxtaposed. In contrast, in the rediscretized regional Edwards aquifer models (Lindgren and others, 2011), HGUs with differing horizontal hydraulic conductivity values were not juxtaposed, and the simulated faults were the primary barriers to flow.

Effective porosity values were varied during model calibration by using PEST simulations to minimize the difference between model-computed and measured age-tracer (tritium) concentrations. The low calibrated effective porosities of about $10^{-4}$ (dimensionless) for the conduit HGUs (HGU5, POR5 and HGU9, POR9) (table 10) indicate that the flow occurs in only a small percentage of the total volume of the aquifer, which is consistent with the concept of flow through conduits. The calibrated effective porosities for the cyclic and marine members (HGU3, POR3), the leached and collapsed members (HGU4, POR4), the grainstone member (HGU7, POR7), and the Kirschberg evaporite member (HGU8, POR8) of the Edwards Group corresponding to the Edwards aquifer were approximately an order of magnitude lower than the initial values, indicating a need to generally increase the particle traveltimes in order to better match the measured tritium concentrations. The calibrated effective porosities increased by approximately an order of magnitude compared to the initial values for the Georgetown Formation (HGU2, POR2) and the basal nodular member (HGU11, POR11) of the Edwards Group (table 10).

\section{Water-Level Altitudes}

The local-scale model was calibrated by using 72 waterlevel measurements representing mean measured water-level altitudes for 2001 and 12 water-level measurements representing mean measured water-level altitudes during 2007-10 from wells in the vicinity of the selected PSW (table 6). The 84 wells with water-level measurements are generally open to multiple HGUs. Twenty-eight water-level measurements were from wells open to two or fewer HGUs (table 6). For 18 of the wells, the open interval was unknown; these wells were assumed to be open to the full saturated thickness of the aquifer. There were 27 water-level measurements from wells open to the HGUs above the regional dense member of the Edwards Group (HGU6), 18 water-level measurements from wells open to the HGUs below the regional dense member of the Edwards Group, and 2 water-level measurements from wells open to only the regional dense member of the Edwards Group (HGU6) (table 6). The remainder of the water-level measurements (37) were from wells open to HGUs above and to HGUs below the regional dense member of the Edwards Group (table 6). The calibrated steady-state simulation generally reproduces the spatial distribution of measured water-level altitudes (fig. 20). Simulated water-level altitudes were within $9.0 \mathrm{~m}$ of measured water-level altitudes at 74 of the 84 wells used as targets for the local-scale model for the calibrated steady-state simulation (fig. 20, table 6). The difference between measured and simulated water-level altitudes was less than $6.0 \mathrm{~m}$ at 64 of the 84 wells and less than $3.0 \mathrm{~m}$ at 42 of the 84 wells. The overall mean absolute difference between simulated and measured water-level altitudes is $4.2 \mathrm{~m}$ (table 6). The largest differences between measured and simulated water-level altitudes (residuals) occur in the western part of the model area and in and near the recharge zone (fig. 20).

Many of the residuals in the eastern two-thirds of the confined zone of the aquifer are less than $1.5 \mathrm{~m}$. The overall RMS error is $6.0 \mathrm{~m}$, which represents about 7.5 percent of the total difference in water level-altitudes (head difference) across the model area. The simulated water-level altitudes for wells open to HGU6 (regional dense member of the Edwards Group) and above matched the measured water-level altitudes best (mean absolute difference of $3.4 \mathrm{~m}$ ), while the poorest match was for wells open to the HGUs below HGU6 (mean absolute difference of $5.1 \mathrm{~m}$ ). The mean absolute difference for wells open to HGUs both above and below HGU6 was intermediate in value, $4.5 \mathrm{~m}$. The mean algebraic difference between simulated and measured water-level altitudes, computed as the algebraic sum of the differences divided by the number of wells, is $1.9 \mathrm{~m}$, indicating that simulated water-level altitudes 


\section{EXPLANATION}
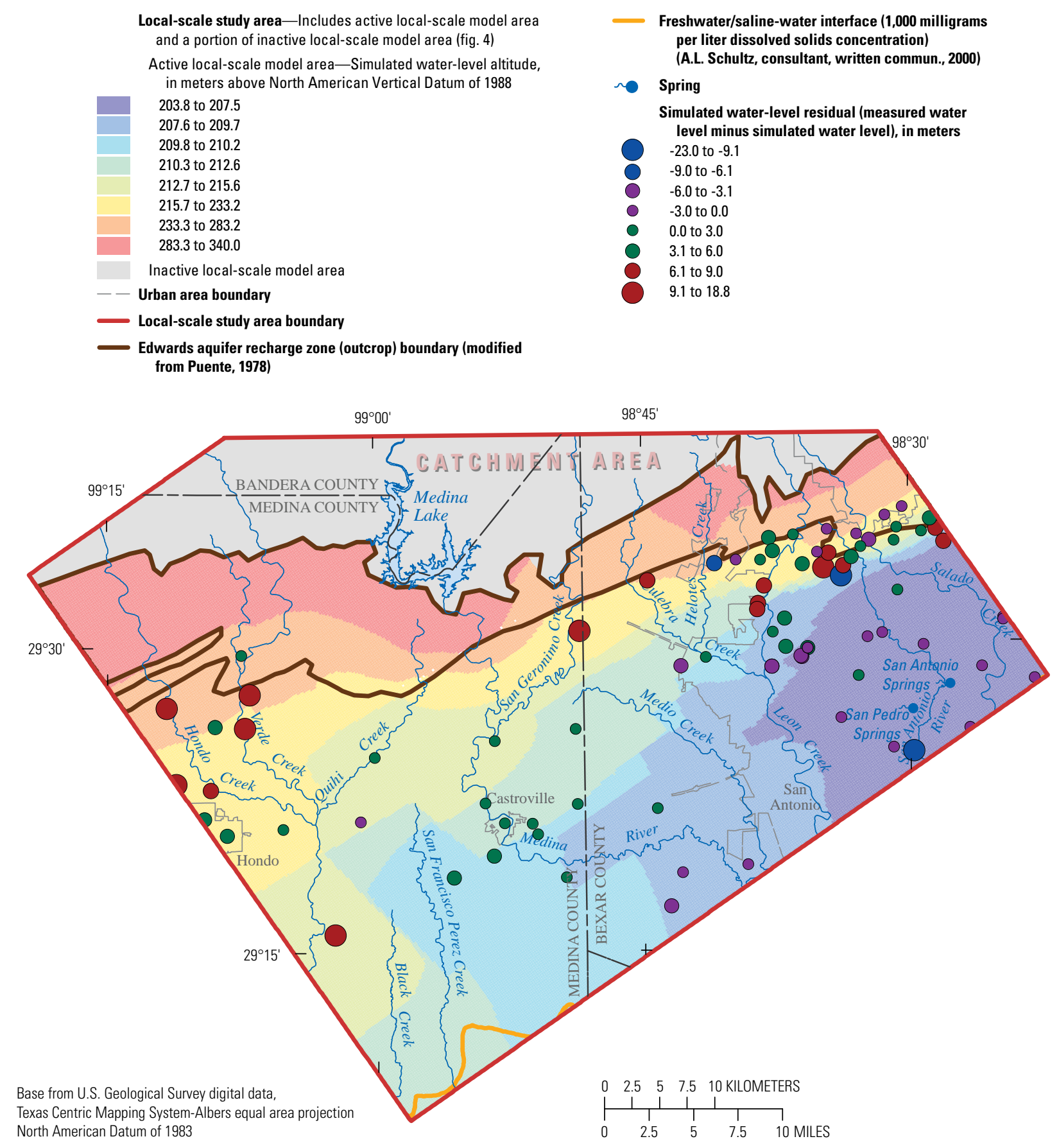

Figure 20. Simulated potentiometric surface and water-level residuals for the local-scale model, San Antonio region, Texas. 
are on an overall basis slightly lower than measured waterlevel altitudes. The graph of simulated relative to measured water-level altitudes indicates that simulated water-level altitudes are neither consistently greater than, nor consistently less than, measured water-level altitudes in the steady-state simulation results for the local-scale model (fig. 21). However, as noted earlier in this paragraph, the largest water-level residuals (absolute difference) tend to occur in the western part of the model area and in and near the recharge zone.

Vertical hydraulic gradients were also analyzed on the basis of the measured and simulated water-level altitudes for the Timberhill and Zarzamora monitoring well nests. Vertical hydraulic gradients were calculated as the differences between the mean daily water-level altitudes during 2007-10 for the wells screened at varying depths in each well nest. The calculated vertical hydraulic gradient for the two Timberhill wells, one screened at an intermediate depth (Timberhill_IED) and the other screened at a deep depth (Timberhill_DED), was $0.2 \mathrm{~m}$, with an upward gradient (table 2). The Zarzamora well nest includes four wells screened in the overburden
(Zarzamora OVB) and at shallow (Zarzamora SED), intermediate (Zarzamora_IED), and deep (Zarzamora_DED) depths in the Edwards aquifer. The calculated vertical hydraulic gradients between the differing well depths varied from a minimum of $0.2 \mathrm{~m}$ upward to a maximum of $6.4 \mathrm{~m}$ downward (table 2). In contrast, the simulated vertical hydraulic gradients, based on the simulated water-level altitudes, were all less than 0.003 $\mathrm{m}$. Probable reasons for the discrepancies between the measured and simulated vertical hydraulic gradients are related to model limitations discussed later in the report in the "Model Uncertainties and Limitations" section, including the simulation of steady-state, rather than transient, conditions and the inherent approximation of the complex hydrogeology at the well nest sites. Figure 5 indicates that for most time periods the differences in water-level altitudes between the wells in a well nest are minimal, with the exception of the Zarzamora site overburden well. The larger differences are generally transient in nature, likely in response to recharge events or pumping changes. Figure 5 also indicates that the direction of the vertical gradients between wells varies temporally,

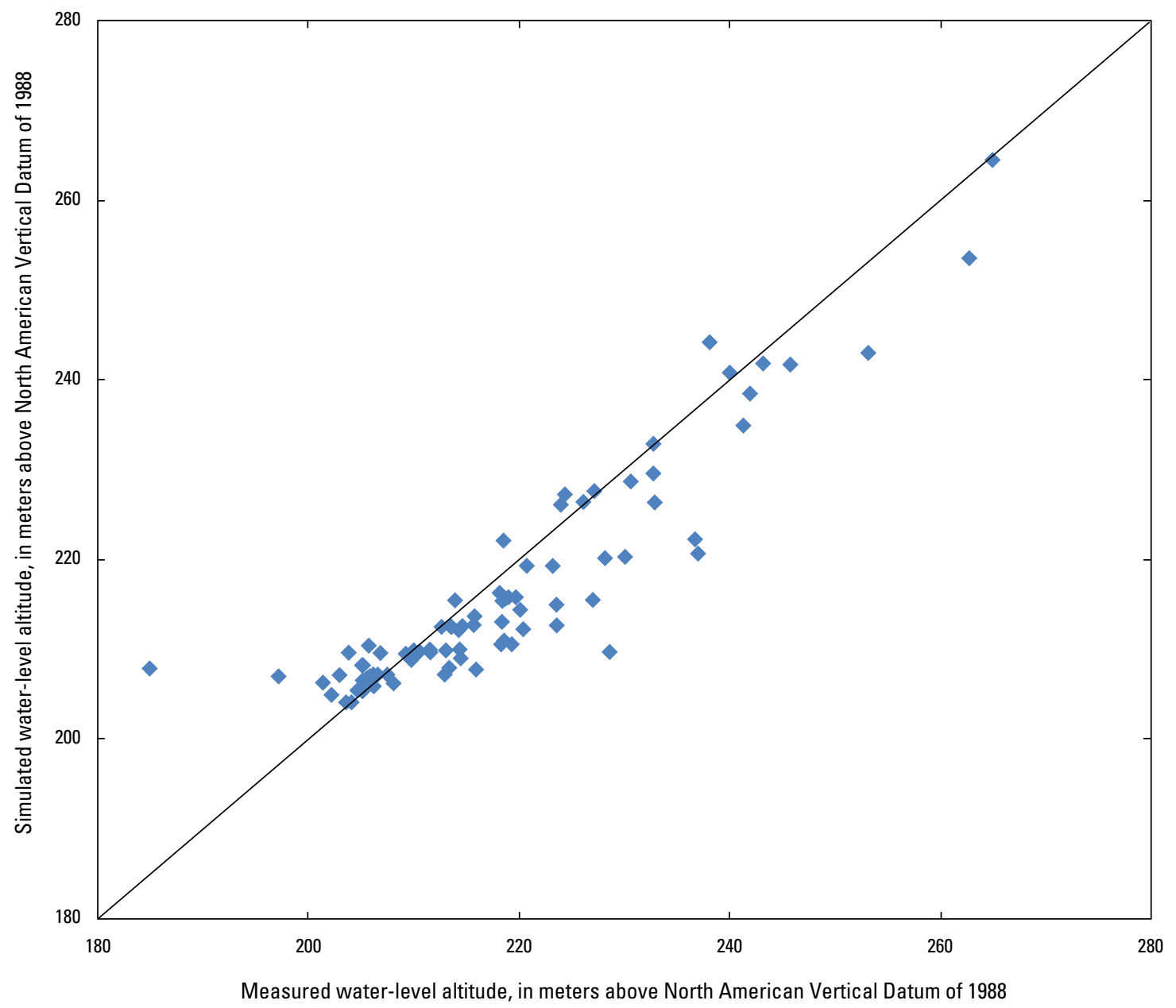

Figure 21. Simulated relative to measured water-level altitudes for the local-scale model, steady-state simulation, San Antonio region, Texas. 
further complicating an assessment of an appropriate representation of the vertical hydraulic gradients for steady-state conditions.

\section{Spring Discharge}

The steady-state simulation calibration results for the local-scale model include a comparison of simulated springflows with median springflows for 2001. The simulated springflow for San Antonio Springs was 7.7 percent greater and for San Pedro Springs was 4.2 percent less than the median measured springflow (table 6 ). The RMS error for the two springs is $0.05 \mathrm{~m}^{3} / \mathrm{s}$, which represents about 6.9 percent of the range in the two measured springflows.

\section{Age-Tracer Concentrations}

Simulated age-tracer (tritium) concentrations were generally in good agreement with measured values in wells in the model area. Simulated tritium concentrations were within $0.35 \mathrm{TU}$ of measured tritium concentrations for the 13 tritium observations (hereinafter, the "local-scale study tritium observations") from 10 wells (hereinafter, the "local-scale study wells") used as observations in PEST simulations to calibrate the local-scale model (table 11 at end of report). Simulated tritium concentrations were within $3.52 \mathrm{TU}$ of measured tritium concentrations for an additional 42 tritium observations (hereinafter, the "NAWQA tritium observations") from 29 wells (hereinafter, the "NAWQA wells") not used as observations in the PEST simulations (table 11). These measured tritium concentrations were not used to calibrate the localscale model because the sample dates in the 1990s and the appreciably longer simulated mean particle traveltimes to the wells indicate that the hydrologic conditions simulated in the local-scale model might be less representative of the hydrologic conditions associated with the NAWQA tritium observations than those associated with the local-scale study tritium observations. However, the measurements are useful as an indicator of the capability of the local-scale model to simulate tritium concentrations in water at wells within the model area, in addition to the relatively few and closely spaced local-scale study wells. The mean absolute difference between simulated and measured tritium concentrations for the NAWQA wells is $0.64 \mathrm{TU}$, and the mean algebraic difference is $0.31 \mathrm{TU}$ (table 11). The RMS error is $1.01 \mathrm{TU}$, which represents about 27 percent of the range in the measured tritium concentrations for the 42 NAWQA tritium observations. The appreciably higher mean absolute difference for the NAWQA tritium observations $(0.64 \mathrm{TU})$ compared to the local-scale study tritium observations $(0.11 \mathrm{TU})$ likely reflects the multiple sampling dates and resulting greater variability in hydrologic conditions for the NAWQA tritium observations. The graph of simulated relative to measured tritium concentrations for the local-scale study and NAWQA tritium observations indicates little bias in the steady-state simulation results, with the data points relatively evenly distributed on both sides of the one-toone line (fig. 22).

The mean absolute difference between simulated and measured tritium concentrations for the local-scale study wells is $0.11 \mathrm{TU}$, and the mean algebraic difference is -0.04 TU (table 11). The mean algebraic difference of -0.04 indicates that positive differences are approximately balanced by negative differences and that there is minimal bias in the simulated concentrations, except for possibly a tendency to underestimate tritium concentrations at the higher measured tritium concentrations (fig. 23). The RMS error is $0.14 \mathrm{TU}$, which represents about 27 percent of the range in the measured tritium concentrations for the 13 observations. Simulated tritium concentrations were within 0.14 TU of measured concentrations for 11 of the 13 local-scale study tritium observations (table 11). The largest differences were for the shallow-depth observation for the selected PSW (0.35 TU) and the wellhead observation for PSW WZ5W (0.25 TU),

with simulated concentrations that were less than the measured concentrations. The mean absolute differences between simulated and measured tritium concentrations, grouped by the sampling location (at the wellhead) or sampling depth (shallow, intermediate, or deep), are similar among values grouped as wellhead, intermediate, or deep observations $(0.09,0.06$, and $0.11 \mathrm{TU}$, respectively). The mean absolute difference for the shallow grouping (0.23) is higher because there are only two observations, and one of the observations (WZ4S) had the highest absolute difference $(0.35 \mathrm{TU})$ of the 13 observations.

Simulated tritium concentrations in the selected PSW during November 2007 were within 0.09 TU of the measured concentrations, with the exception of the shallow depth observation (WZ4S) (table 11). The simulated concentrations were higher than the measured concentrations for the wellhead, intermediate, and deep depth observations but were lower for the shallow depth observation. The vertical pattern in the measured tritium concentrations for the depth-dependent sampling in the selected PSW has the highest concentration for the shallow depth observation, the lowest concentration for the intermediate depth observation, and the middle concentration for the deep depth observation (fig. 15B, table 11). The simulated concentrations follow the pattern for the intermediate and deep observations but not for the shallow-depth observation. The vertical pattern in the measured tritium concentrations observed in the selected PSW is also seen in the concentrations for the Zarzamora well nest (fig. 15B, table 11). However, for the Zarzamora wells, simulated concentrations follow the pattern for the shallow and deep depth observations, but the simulated concentration for the intermediate depth observation is greater than the concentrations for the other two observations. The measured and simulated concentrations for the Timberhill wells indicate a lower concentration for the deep depth observation than for the intermediate depth observation. The meaning of the patterns in the vertical distribution of measured tritium concentrations observed in the selected PSW and in the Zarzamora and Timberhill well nests 


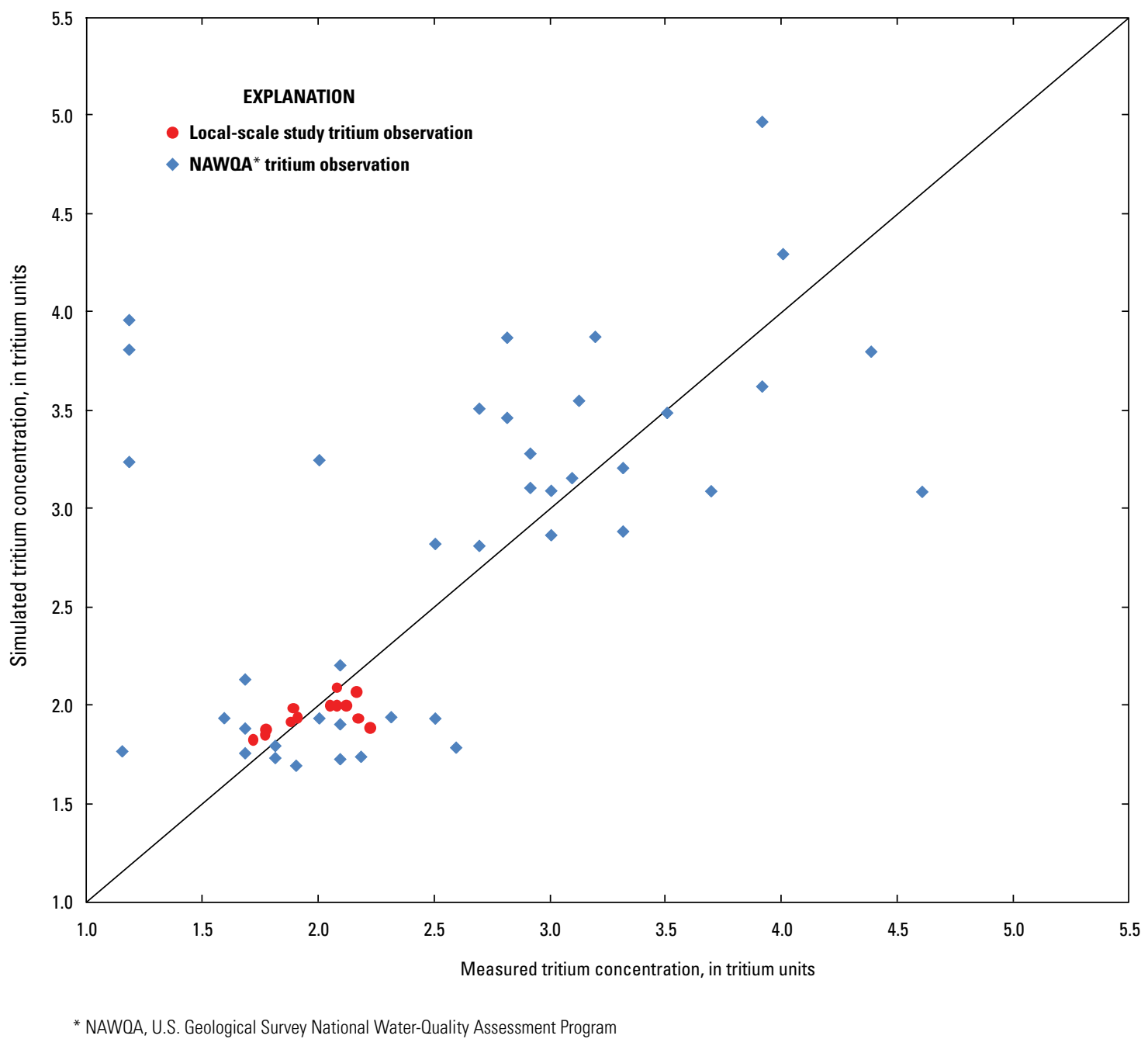

Figure 22. Simulated relative to measured tritium concentrations for the local-scale model, steady-state simulation, San Antonio region, Texas.

is not clear because the differences in measured concentrations between the well depth observations might be less than the uncertainty in the measurements.

Poor matches between measured and simulated tritium concentrations might be a result of model limitations, such as inexact representations of karst features and their placement, the assumption of steady-state flow, and the inability of the Modpath computer code to account for diffusion and dispersion in the MODPATH simulations. In addition, uncertainty exists regarding exactly what depth interval or amount of flow to the well each of the tritium concentration observations represents. Poor matches between measured and simulated tritium concentrations for the selected PSW might also be attributable to the appreciably higher simulated pumping rate for the selected PSW compared to the pumping rate used for collecting depth-dependent samples, as discussed previously in the Data Collection and Analysis section.

\section{Model Results}

Model output from the MODFLOW local-scale model includes simulated water-level altitudes, cell-by-cell flows and water budgets. MODPATH was used to estimate water-particle traveltimes and ACR for the selected PSW and monitoring wells.

\section{Simulated Groundwater Flow}

The simulated potentiometric surface (fig. 20) was generally representative of the measured potentiometric surface (fig. 11) in the local-scale model area. The major components of groundwater flow in the local-scale model area are (1) from the recharge zone southward into the confined zone and (2) from west to east in the confined zone toward the major springs (Comal and San Marcos Springs) east of the 


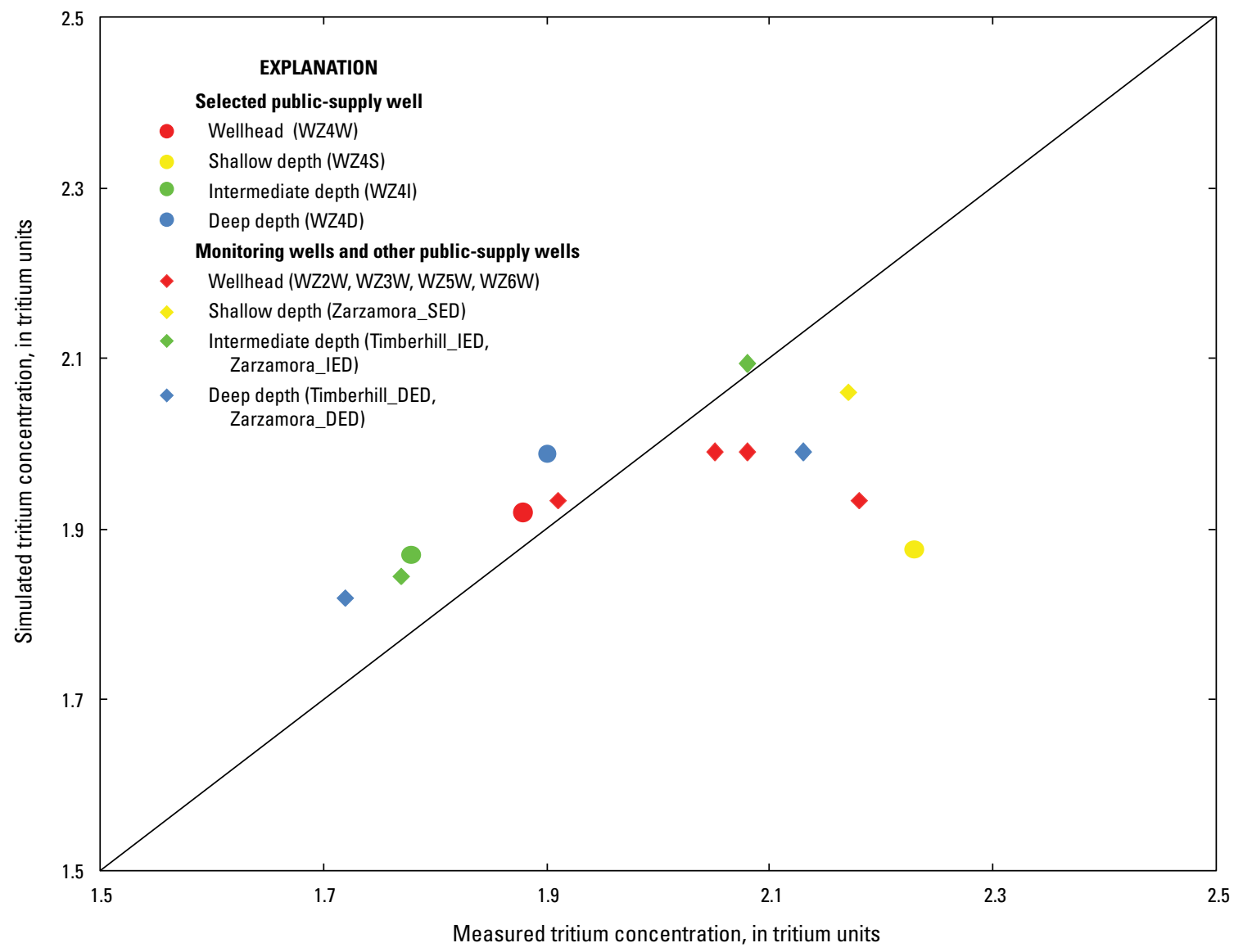

Figure 23. Simulated relative to measured tritium concentrations in the selected public-supply well and monitoring wells for the localscale model, steady-state simulation, San Antonio region, Texas.

local-scale model area. Water in the local-scale model flowed from the recharge zone toward the south and southeast into the confined zone. Water-level altitudes decreased from north to south, from north to southeast, and from west to east across the local-scale model area and were in generally good agreement with the observed flow directions.

Structures simulated in the local-scale model influencing groundwater flow that tend to restrict flow include largedisplacement faults. The influence of simulated faults on flow directions is most evident in northern Medina County. In this area, the direction of groundwater flow is affected primarily by large-displacement, parallel northeastwardstriking faults (fig. 12) that divert flow toward the southwest. The steep regional slope of the potentiometric surface is toward the southeast, but these faults, as local barriers to southeastward flow, divert the flow toward the southwest. The diversion of flow to the southwest can be seen in measured (fig. 11) and simulated (fig. 20) potentiometric surfaces. Water-level altitudes abruptly change across segments of the large-displacement faults in some areas, in particular in the western part of the local-scale study area in Medina County and in west-central Bexar County (fig. 12). Comparatively large simulated water-level changes across faults are indicated in these areas by the coincidence between breaks (changes in color) in the simulated zones of water-level altitudes in figure 20 and the traces of large-displacement faults in figure 12 .

\section{Simulated Water Budget}

In addition to water-level altitudes, the water budget for the model is computed. A water budget in the context of the model is an accounting of inflow to, outflow from, and storage change in the aquifer. For steady-state conditions, inflow (sources) to the aquifer equal outflow (discharges) from the aquifer. The steady-state simulation water budget indicates that recharge occurring in the local-scale study area accounts for 31.8 percent of the sources of water to the Edwards aquifer in the local-scale model area and that inflow through the model boundaries contributes 68.2 percent (table 12 at end of report). Most of the flow into the local-scale model area through the model boundaries occurs through the western and southern boundaries, 58.2 and 39.6 percent, respectively. The net flow through the western boundary is into the local-scale model area (fig. 24) and constitutes 80.0 percent of the total flow (both into and out of the local-scale model area) through 


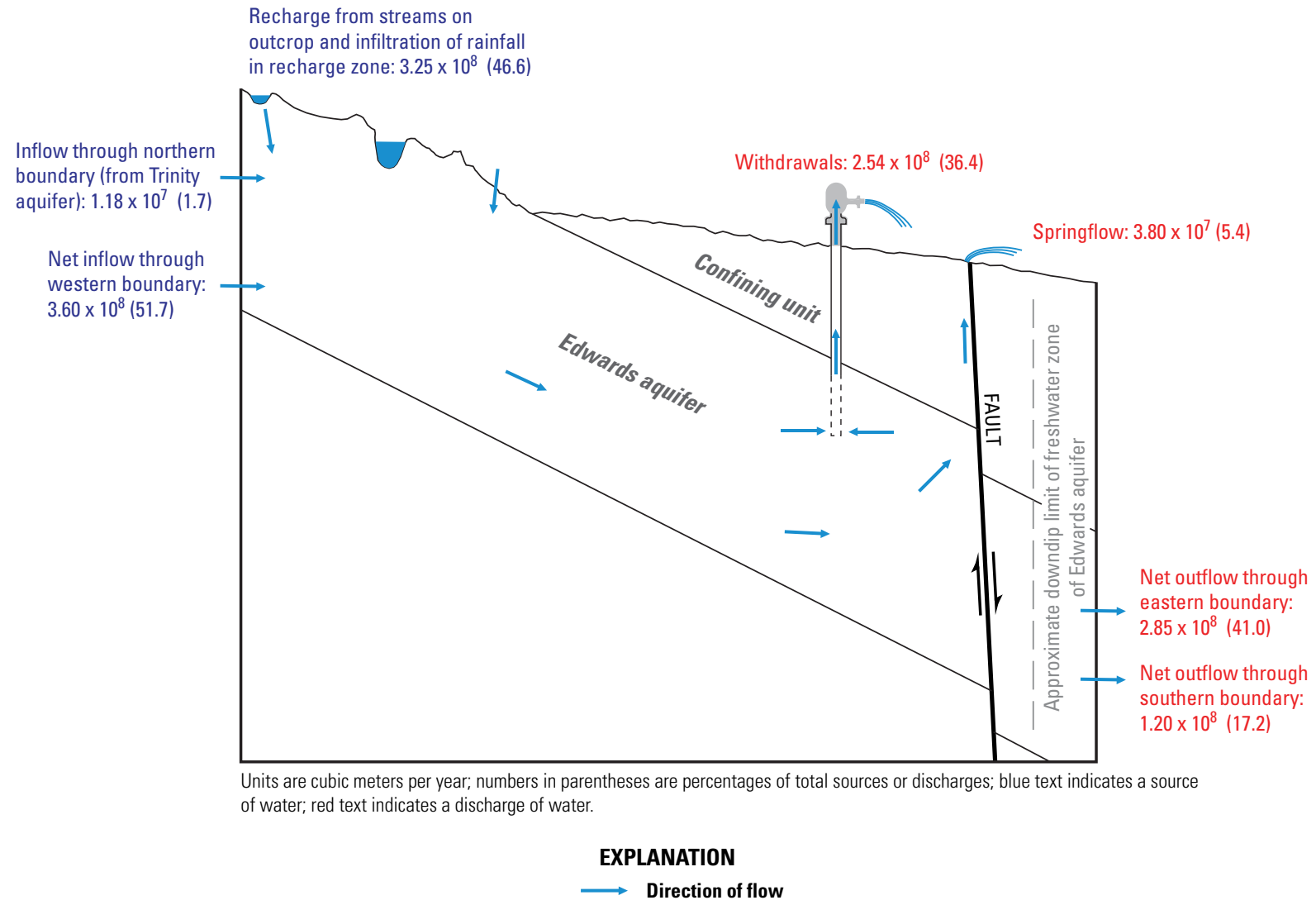

Figure 24. Simulated water-budget components for the local-scale model, steady-state simulation, San Antonio region, Texas.

the western boundary (table 8). All of the flow through the northern boundary is into the local-scale model area and represents flow from the Trinity aquifer into the Edwards aquifer (fig. 24, table 12). Flow through the northern boundary constitutes a comparatively small part (1.7 percent) of the total boundary inflow under steady-state conditions. A very small amount of flow into the local-scale model area also occurs through the eastern model boundary in the recharge zone.

The largest discharges from the Edwards aquifer in the local-scale model area are boundary outflow (71.4 percent) and withdrawals by wells (24.9 percent) (table 12). Most of the flow out of the local-scale model area through the model boundaries occurs through the southern and eastern boundaries, 54.2 and 39.6 percent, respectively. The net flow through the southern boundary is out of the local-scale model area (fig. 24) and constitutes only 17.8 percent of the total flow (both into and out of the local-scale model area) through the southern boundary (table 8). In contrast, the net flow out of the eastern boundary (fig. 24, table 12) constitutes most (97.7 percent) of the total flow (both into and out of the local-scale model area) through the eastern boundary (table 8). A small amount of flow out of the local-scale model area also occurs through the western model boundary in the recharge zone.
Springflow from San Antonio and San Pedro Springs contribute a small amount (3.7 percent) to the total discharge.

\section{Simulated Zones of Contribution, Areas Contributing Recharge, and Water Particle Ages}

The simulated ZOCs and ACR to the selected PSW, Zarzamora well nest, and Timberhill well nest are shown in figures 25,26 , and 27 , respectively. The ZOCs for all three sites extend to the north, northeast, and northwest from each site in the confined zone of the aquifer into the recharge zone, where all recharge to the aquifer occurs. The areal extent of the surficial expression of the simulated ZOC is about 44,040 hectares for the selected PSW, about 29,320 hectares for the Zarzamora well nest, and about 18,540 hectares for the Timberhill well nest. The ACR for each site is restricted to the recharge zone. Although the simulated ACR for the selected PSW and nearby well nests in San Antonio likely do not represent the true areas contributing recharge, they are a useful tool for delineating approximate areas that may serve as sources of groundwater recharging the wells and potential sources of contaminants at the time of recharge. The simulated ACR in figures 25-27 are represented as networks of model-grid cells, some of which are contiguous and others disconnected. The "patchy" 


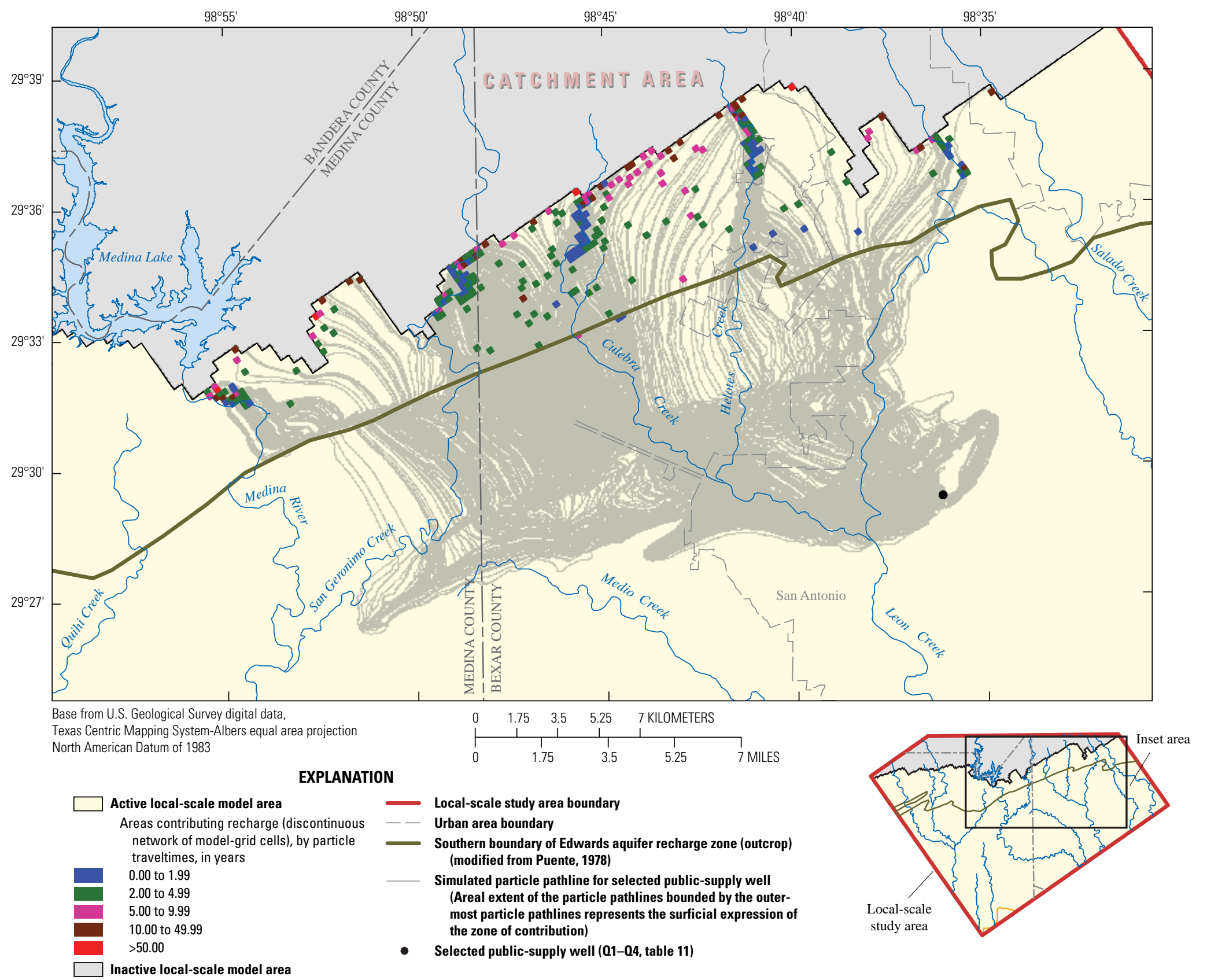

Figure 25. Simulated areas contributing recharge, age of water particles derived from simulated particle traveltimes, and particle pathlines for the selected public-supply well, San Antonio region, Texas. 


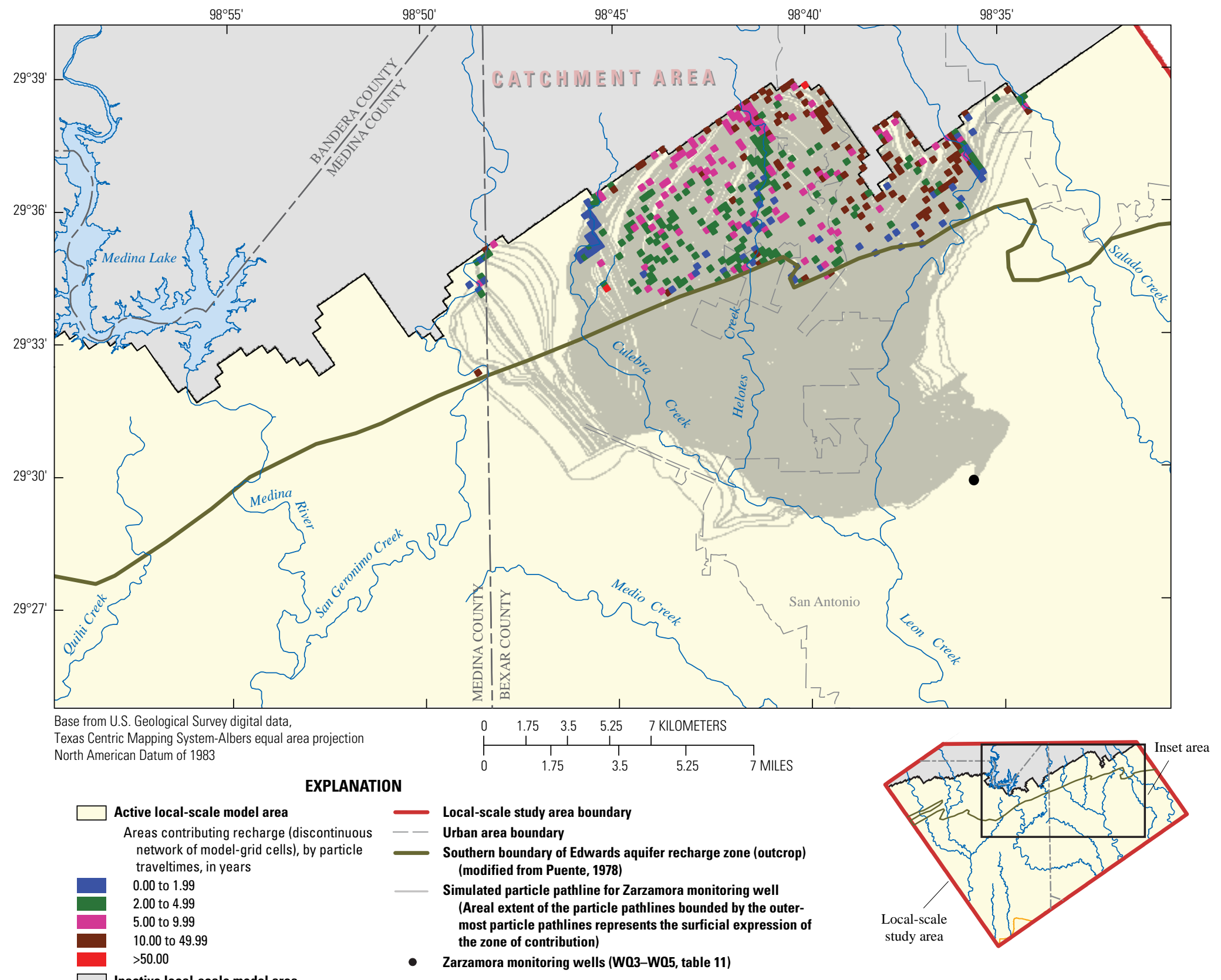

Figure 26. Simulated areas contributing recharge, age of water particles derived from simulated particle traveltimes, and particle pathlines for the Zarzamora monitoring wells, San Antonio region, Texas. 


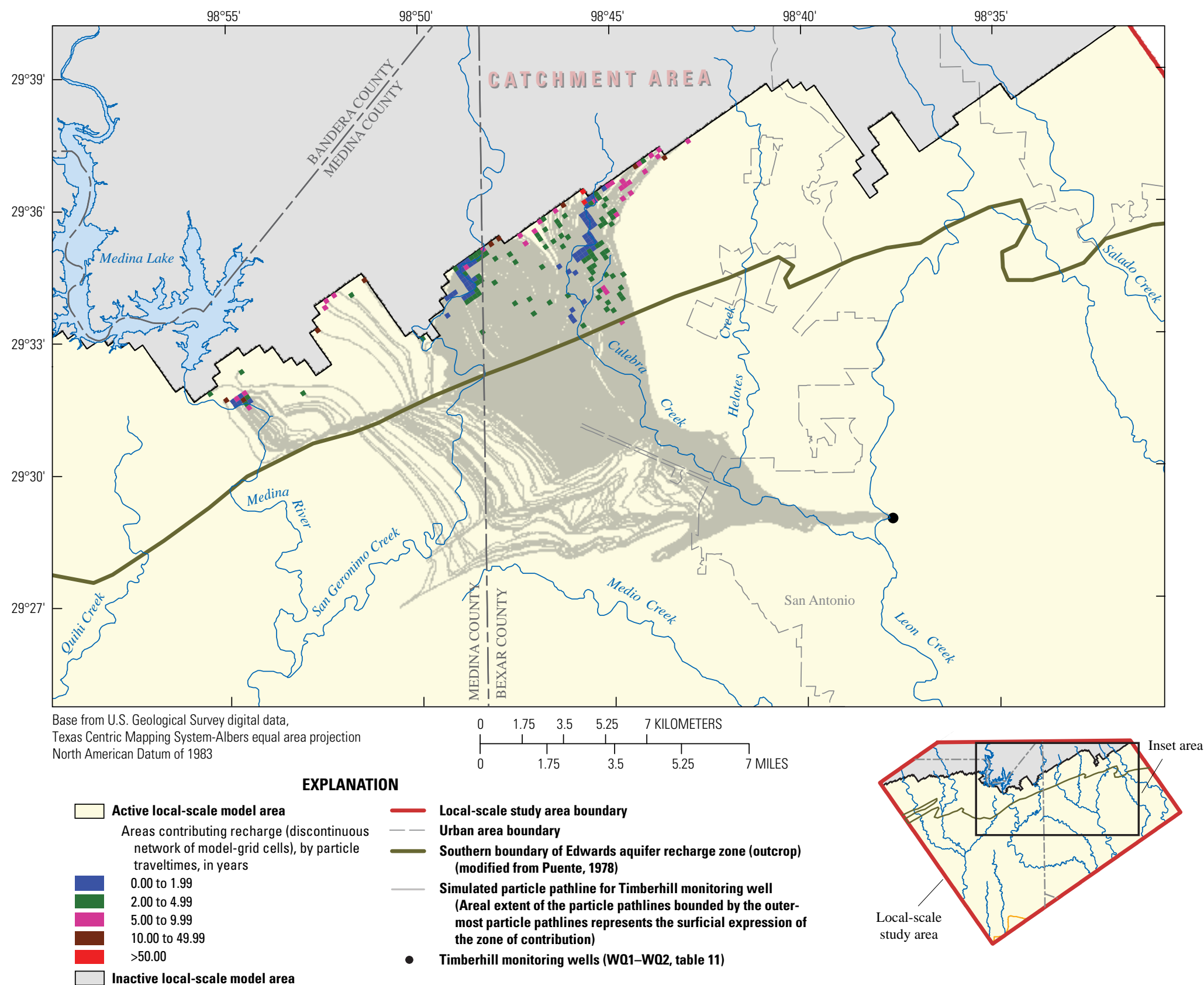

Figure 27. Simulated areas contributing recharge, age of water particles derived from simulated particle traveltimes, and particle pathlines for the Timberhill monitoring wells, San Antonio region, Texas. 
(discontinuous) appearance of the ACR probably represents different simulated flow paths of water particles traversing different HGUs with widely differing hydraulic conductivities and effective porosities. The "patchy" (discontinuous) appearance of the ACR is likely particularly affected by the extent to which the flow paths of water particles traverse the two conduit HGUs (HGU5 and HGU9) with comparatively high hydraulic conductivities, low effective porosities, and rapid flow.

The ACR to the selected PSW, Zarzamora well nest, and Timberhill well nest differ in their extent and cumulative area (total area of the discontinuous network of model grid cells) (figs. 25, 26, and 27, respectively). The ACR for the selected PSW has the greatest extent, from the San Antonio River on the east to the Medina River on the west, and the largest cumulative area, about 12,240 hectares. The ACR for the Timberhill well nest (located northwest of the selected PSW) has the least extent, encompassing approximately the western one-half of the ACR for the selected PSW, and the smallest cumulative area, about 6,210 hectares. The ACR for the Zarzamora well nest (northeast of the selected PSW) is intermediate in its extent and cumulative area, encompassing approximately the eastern two-thirds of the ACR for the selected PSW and covering an area of about 11,670 hectares. The extent of the ACR for the Zarzamora well nest is appreciably smaller than that for the selected PSW, but the cumulative areas for the two sites (selected PSW and Zarzamora well nest) are similar (11,670 and 12,240 hectares, respectively). This is because the simulated endpoint locations of water particles contributing water to the Zarzamora well nest occur within a smaller area and are more dense (less scattered) than those for the selected PSW (figs. 25 and 26). The ACR for the selected PSW has the greatest extent because the simulated particle endpoints include the flow contribution for the entire open interval of the well (simulated for the wellhead sampling), whereas the screened intervals for the Timberhill and Zarzamora wells are much shorter (3-4.5 m) and the simulated particle endpoints include the flow contribution for only two (Timberhill well nest) or three (Zarzamora well nest) depth intervals. In addition, the selected PSW is actively withdrawing water, creating flow towards the well, whereas the Timberhill and Zarzamora wells are monitoring wells with no groundwater withdrawals.

Simulated particle ages ranged from less than 1 day to more than 1,900 years in the 10 local-scale study wells (13 local-scale study tritium observations) used to calibrate the local-scale model (table 13 at end of report). Simulated particle ages ranged from less than 1 day to more than 14,000 years in the 29 NAWQA wells (42 NAWQA tritium observations) (table 13). The simulated particle ages for the localscale study tritium observations representing selected well depths (shallow, intermediate, and deep) ranged from less than 1 day to 621 years. The minimum (youngest) particle ages for the selected PSW and the Zarzamora well nest were for the deep well depth, while the youngest particle age for the Timberhill well nest was for the intermediate well depth (table 13). The maximum (oldest) particle age for the Zarzamora well nest was for the shallow well depth, while the oldest particle age for the selected PSW and the Timberhill well nest was for the deep well depth. The wellhead or composite mean particle ages in the 10 local-scale study wells (13 local-scale study tritium observations) ranged from 3.7 to 7.6 years and was youngest for the Timberhill well nest and oldest for the Zarzamora well nest (table 13). The mean particle age in the 29 NAWQA wells (42 NAWQA tritium observations) was 42 years, about 2.8 times greater than the maximum mean particle age for the 10 local-scale study wells in the vicinity of the selected PSW (table 13). The reason for the greater mean particle age for the NAWQA wells may be that some of the wells receive contributions of water (simulated particles) with longer flow paths, and therefore presumably older age, than do the 10 local-scale study wells.

The simulated mean particle ages for the tritium observations representing selected well depths (shallow, intermediate, and deep) ranged from 2.5 to 15 years. The minimum (youngest) mean particle ages for the selected PSW and the Timberhill well nest were for the intermediate well depth, while the youngest mean particle age for the Zarzamora well nest was for the intermediate and deep well depths (table 13). The maximum (oldest) mean particle ages for the selected PSW and the Zarzamora well nest were for the shallow well depth. The likely reason that the maximum (oldest) mean particle ages for the selected PSW and the Zarzamora well nest were for the shallow well depth is that the shallow well depth (sampling depth) lies above the simulated conduit HGUs (HGU5 and HGU9), thereby lessening the contribution from the low effective porosity HGUs and fast flow paths. The mean of simulated particle ages for tritium observations representing well depths open to the conduit HGUs was 3.8 years, whereas the mean of simulated particle ages for tritium observations representing well depths not open to the conduit HGUs was 9.6 years. The vertical pattern in the simulated particle ages for the depth-dependent sampling in the selected PSW follows the same pattern as for the measured tritium concentrations (tables 11 and 13). The shallow-depth observation has the highest measured concentration and maximum (oldest) simulated mean particle age, the intermediate depth observation has the lowest (youngest) measured concentration and minimum simulated mean particle age, and the deep depth observation has an intermediate measured concentration and simulated mean particle age.

Apparent groundwater ages were available for 10 of the 13 local-scale study tritium observations used to calibrate the local-scale model. The apparent groundwater ages, derived from concentrations of the geochemical tracer tritium, ranged from 0.8 to 41.3 years (table 13) (Musgrove and others, 2011). The simulated particle ages and apparent groundwater ages shown in table 13 represent pumping conditions with the test well (selected PSW, WZ4W) and the other wells in the well field pumping. The apparent groundwater ages are greater (older) than the simulated particle ages, with the exception of the deep depth observation for the Zarzamora well nest and the wellhead and shallow observations for the selected PSW 
(WZ4W). The greatest differences between the simulated particle ages and the apparent groundwater ages are for the Timberhill well nest observations, where apparent groundwater ages were much older than the simulated particle ages. A likely reason for this discrepancy is that geophysical logging and flow measurements made at the selected PSW and the Zarzamora and Timberhill well nests indicated less permeable, tighter material and less hydraulic connection with nearby pumping wells for the Timberhill well nest site than was the case for the selected PSW and the Zarzamora well nest sites. These site-specific hydraulic properties (that is, at the Timberhill well nest site) are not represented in the local-scale model because of the comparatively large model cell size $(201.2 \mathrm{~m}$ on a side) and general lack of detailed hydrogeologic information other than at the three sites investigated for the TANC local-scale study. The simulated particle ages and the apparent groundwater ages indicate an inverse relation between age and depth below land surface (decreasing age with increasing depth below land surface) for the Zarzamora well nest. Also, both the simulated particle ages and the apparent groundwater ages indicate older ages for the wellhead observations for wells WZ2W and WZ3W than for the wellhead observations for well WZ6W and the selected PSW (WZ4W).

\section{Supply-Well Vulnerability to Natural and Anthropogenic Contaminants}

Like many karst aquifers, high porosity and permeability and rapid flow of recharging surface water through conduits, with little to no filtration, render the Edwards aquifer highly susceptible to contamination. Constituents of concern in the Edwards aquifer for the long-term sustainability of the groundwater resource include organic contaminants and the nutrient nitrate $\left(\mathrm{NO}_{3}\right)$ (Musgrove and others, 2011). Measured concentrations of organic contaminants and $\mathrm{NO}_{3}$ are currently low relative to levels of regulation. Nonetheless, the dominance of very young groundwater in the local-scale study area and specifically that reaching the selected PSW and other PSWs in the well field indicates that the aquifer and water supply are vulnerable to contamination. Although changes in pumping conditions might change the distribution of groundwater flow paths contributing water to the well field, under all pumping conditions the majority of the groundwater was young and, as such, is susceptible to anthropogenic contaminants (Musgrove and others, 2011).

The simulated age distribution for contributing-area water particles reaching the selected PSW ranged from less than 1 to 342 years, with a mean of 4.4 years. Particle-tracking (MODPATH) results indicate that 99 percent of the selected PSW water was less than 50 years old and that 88 percent of the water was less than 5 years old (fig. 28). Younger water (less than 50 years old) is more likely to be affected by human activities, and if present, most anthropogenic contaminants would be present in younger water. These model results concur with the conceptual understanding that a large fraction

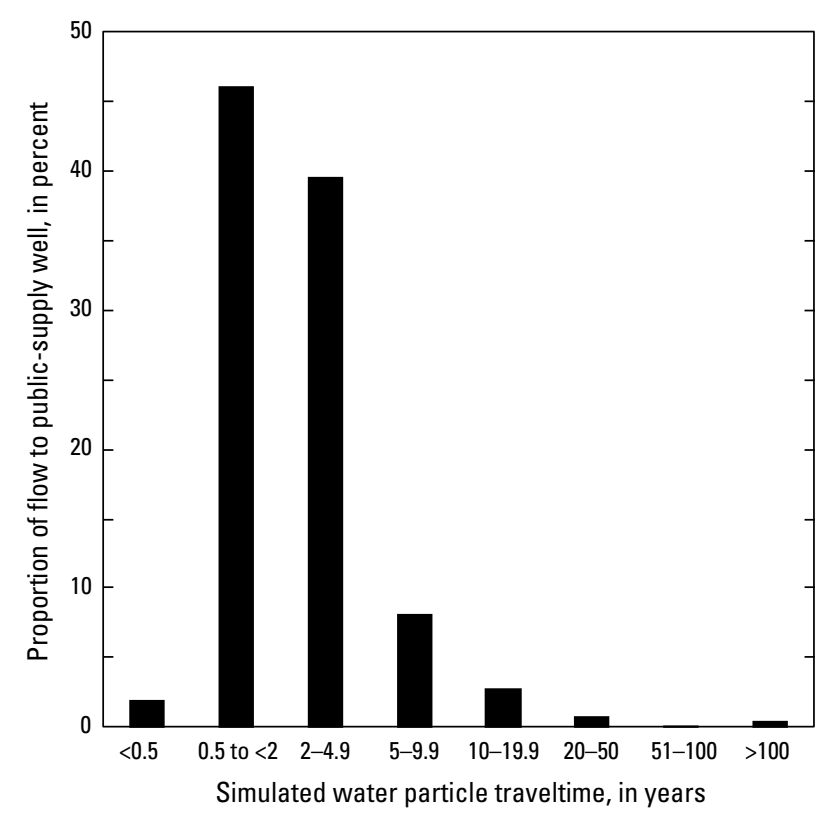

Figure 28. Simulated age of water particles reaching the selected public-supply well, San Antonio region, Texas.

of water in the aquifer, and particularly in the selected PSW, is young (less than 50 years old). Water samples from the selected PSW, other wells in the well field, and other PSWs completed in the Edwards aquifer contain detectable concentrations of a small number of some pesticides and VOCs (Musgrove and others, 2011). Natural attenuation processes are also likely to be limited in flow systems with young groundwater, in particular for conditions or contaminants where degradation processes are slow (Chapelle and Bradley, 1999; McMahon and others, 2008) such as the case in this oxic aquifer. In flow systems with a higher fraction of olderage water (that is more than 50 years old), that fraction could dilute anthropogenic contaminant concentrations when waters of different ages mix within the aquifer and the open borehole of a PSW (Osenbrück and others, 2006).

In a model-forecasting exercise, slug inputs of a hypothetical contaminant were used to examine the range in lag times, dilution, and degradation that might be expected at the selected PSW (Musgrove and others, 2011). Results of this exercise might be representative of a rapid land-use change overlying the contributing area of a PSW in the local-scale study area and might represent how quickly the aquifer responds to mitigation. The hypothetical contaminant was introduced over the ACR for the selected PSW continuously for 30 years. Each ACR (recharge zone) cell was loaded with a relative contaminant concentration of 1 (that is, relative to a background concentration of 0 ). After 30 years, the contaminant input returned to zero. The hypothetical response at the PSW is illustrated in figure 29 for (1) a simulation with no contaminant degradation and (2) a simulation with 


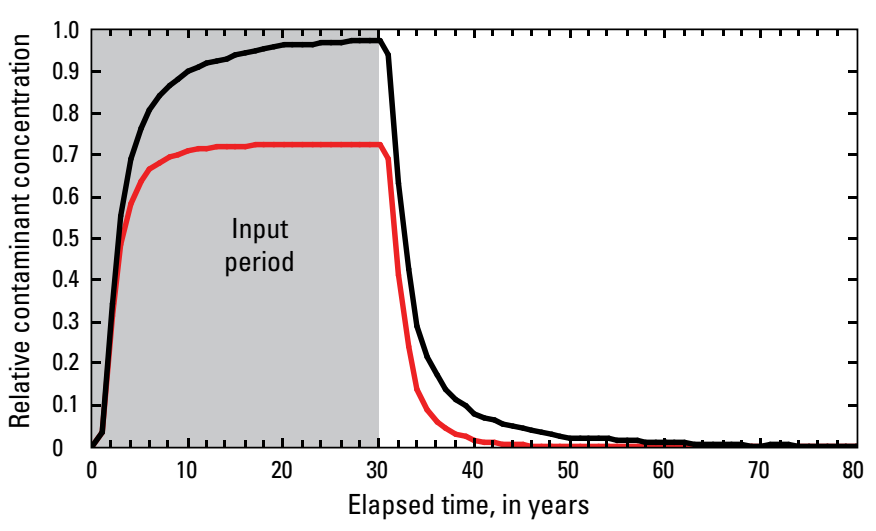

EXPLANATION

No degradation With degradation (0.1)

Figure 29. Simulated time series of hypothetical contaminant concentrations at the selected public-supply well based on 30 years of contaminant input (at relative concentration of 1) in the simulated areas contributing recharge, San Antonio region, Texas.

contaminant degradation at a first-order reaction kinetics degradation rate of 0.1 per year (10 percent per year). For both responses (curves in fig. 29), concentrations at the selected PSW began to rise within 1 year after loading began and rose quickly to reach 50 percent of peak concentration in 3 (with nondegradation) or 4 years (with degradation). The nondegradation curve continued to rise rapidly until about 5 years, when 77 percent of peak concentration was reached. Concentrations continued to rise for both curves until peak concentrations were reached at the end of the input period of 30 years. Maximum concentrations were 98 percent of input for the nondegradation curve and 73 percent of input for the withdegradation curve. Once the input was stopped after 30 years, both simulations responded with a rapid drop in concentration. Concentration decreased to about 50 percent of input in 3 years in the nondegradation simulation and in a little more than 2 years for the with-degradation simulation. Concentration decreased to 25 percent of input in 5 years (nondegradation) and in less than 4 years (with degradation). Although peak concentrations dropped quickly after input ceased, 32 and 12 years were required, respectively, to flush 99 percent of the hypothetical contaminant and achieve near background conditions (Musgrove and others, 2011).

Lag times would be expected to be shorter for wells with large fractions of young water (McMahon and others, 2008), such as observed for this study, than for wells with smaller fractions of young water. The effect of short-circuit pathways, for example karst conduits, in the flow system on the movement of young water to the selected PSW could greatly alter contaminant arrival times compared to what might be expected from advection in a system without short circuiting. This observation is particularly valid for karst such as the Edwards aquifer: numerous voids are present in wells completed in this aquifer, including the selected PSW. In the forecasting exercise, the simulated concentrations showed rapid initial response at the beginning and end of chemical input, followed by more gradual response as older water moved through the system. The nature of karst groundwater flow, where flow predominantly occurs via conduit flow paths, could lead to relatively rapid water quality responses to land-use changes.

The forecasting exercise did not consider chemical storage and transit times in the unsaturated zone, dispersion/diffusion, or transient flow conditions in the aquifer, which might yield substantially different results (Musgrove and others, 2011). Transient conditions in the flow system could result in more complex ACR and groundwater age distributions than were assessed here and should be considered in future studies (Franke and others, 1998; Rock and Kupfersberger, 2002). Spatial variability in input, which would likely have considerable effect on concentrations and movement of contaminants, also was not considered. The spatial component of land-use change is also important because the complex distribution of particle traveltimes within the ACR strongly influences contaminant arrival times and degradation reaction progress. Results from this forecasting exercise and other similar exercises (McMahon and others, 2008) indicate that timescales for change in the quality of water from the selected PSW could be on the order of a few years to decades for land-use changes that occur over days to decades, which has implications for source-water protection strategies that rely on land-use change to achieve water-quality objectives.

\section{Model Uncertainties and Limitations}

An understanding of model limitations is essential to appropriately use groundwater-flow and particle-tracking simulation results. The accuracy of groundwater-flow models is limited by simplification of complexities within the flow system, by space and time discretization effects, and by assumptions made in the formulation of the governing flow equations. Model accuracy also is limited by cell size, number and representation of layers, accuracy of boundary conditions, accuracy and availability of data on hydraulic properties, accuracy of groundwater withdrawal and groundwater recharge estimates, historical data for calibration, parameter sensitivity, and the interpolations and extrapolations that are inherent in using data in a model. In addition, a combination of input values to the model different from those used in the calibrated simulations could produce the same result; the solution is not unique.

Models solve for average conditions within each cell, the parameters for which are interpreted or extrapolated from measurements and estimated during calibration. The relatively coarse grid cell size ( $201.2 \mathrm{~m}$ on a side) of the local-scale model does not fully incorporate the complex hydrogeology of the karstic Edwards aquifer. Hydrogeologic units often have 
characteristics, such as being thin or pinching out or being faulted and discontinuous, that make them difficult or impossible to represent with any model. Scant information exists regarding hydraulic properties, flow rates, and karst features of the Edwards aquifer HGUs other than the geophysical logging conducted by the USGS in 2008 (Gregory Stanton, U.S. Geological Survey, written commun., 2008) in the selected PSW and nearby monitoring wells. Therefore, the results from the selected PSW and nearby monitoring wells were extrapolated throughout the local-scale model area. In addition, in the local-scale model the overburden is simulated as a single HGU with uniform hydraulic properties representing multiple geologic units. The boundary conditions for the local-scale model are derived from the regional-scale model. To the extent that the regional model may contain errors in representing the flow system in the local-scale model domain, the boundary conditions used in the local-scale model also could be a source of model error.

Additional uncertainties and limitations apply in regard to the MODPATH particle-tracking simulations. The assumed local-scale model boundary conditions may affect the age distribution of particles entering the simulated wells and the simulated ACR. A small portion of those particles were found to originate from the northern model boundary itself, indicating that the complete ACR to wells might not be delineated. However, the effects of particles originating from the northern model boundary itself are likely minimal because the inflow through the northern model boundary is only about 1 percent of the total sources of water to the aquifer. The relatively coarse discretization of the model grid might also affect the simulated ACR for the selected PSW. The selected PSW and two other PSWs are all located in row 230, column 264 of the model grid and are screened across partially overlapping model layers. Because the model grid cells (one row, column location but multiple model layers) containing the selected PSW contain two other PSWs, the simulated ACR for the selected PSW may be more representative of the combined ACR for the three PSWs than specifically for the selected PSW alone. Dispersion, diffusion, adsorption, retardation, degradation, or any other transport process affecting the concentrations of contaminant constituents is not included in the MODPATH simulation for determining traveltimes of water. Estimates of groundwater traveltimes and ACR can be in error if the effects of dispersion and mixing on age-tracer (tritium) concentrations are ignored. Advection-dispersion transport simulations would likely yield larger ACR than would advective particle-tracking simulations because the effects of dispersion caused by aquifer heterogeneity would be included.

It is assumed for a steady-state model that the system is in equilibrium. Water-level hydrographs indicate that this generally is the case in the local-scale model area over time. Long-term hydrographs (about 80 years) indicate no net decline (or rise) of water-level altitudes in the San Antonio region. Average stresses (recharge and pumpage) during 2001 were used to simulate steady-state conditions for the local-scale model. Errors related to this assumption of steady-state could be notable, and consideration should be taken in interpreting model results and analyses that depend on model output, particularly for the particle-tracking results. For steady-state simulations, an analytical expression for the flow path in each cell is calculated by direct integration of the velocity components. The traveltime calculated by this method represents an average traveltime for the advection of a "particle" of water or a conservative solute.

The entire potential timeframe associated with the movement of tritium from the source area (recharge zone) to the wells (about 40 years; 1969-2009) is not necessarily subject to the same hydrologic conditions as those used to calibrate the local-scale steady-state model (average stresses during 2001). The similarity between the mean measured waterlevel altitudes for 2001 and 2000-10 might indicate that the local-scale model results are more representative of recent hydrologic conditions (2000-10) than they are of hydrologic conditions longer ago. Apparent groundwater ages in a karst system such as the Edwards aquifer reflect mixtures of water that likely vary temporally as a result of changes in hydrologic conditions; therefore, a one-time sampling (or narrow window of sampling time) might not provide representative apparent groundwater ages (Musgrove and others, 2009). Variability in hydrologic conditions and the transient nature of the Edwards aquifer likely do influence measured tritium concentrations and apparent groundwater ages, and these transient effects are not accounted for in the local-scale steady-state model. However, a large dataset of historical tritium values that would be necessary to quantitatively account for transient effects on tritium concentrations is not available for the Edwards aquifer.

Variability in hydrologic conditions and transient effects not accounted for in the local-scale steady-state model include cyclic hydrologic conditions that are similar in length to mean particle traveltimes or mean particle traveltimes that are shorter than the duration of cyclic hydrologic conditions. The simulated steady-state mean traveltimes to wells in the ACR to the selected PSW for this study are generally less than 5 years. The effects of long-term cyclic hydrologic conditions that occur over multiple years, such as droughts, on traveltimes to wells is largely unknown for the Edwards aquifer because of a lack of applicable age-tracer data and is beyond the scope of this study. Fast flow paths (conduits) have been documented by dye-tracing experiments in the Edwards aquifer and are simulated in the local-scale steady-state model that result in short traveltimes of less than 1 year for a small portion of the water particles reaching a well. In addition, there are likely fast flow paths not represented in the local-scale model which cause more variation in the traveltime distributions and locations of ACR than would be computed by either steady-state or transient simulations. Traveltimes of particles through the fast flow paths are unlikely to be appreciably affected by longterm hydrologic cycles but may be affected by seasonal or shorter term cycles. However, as previously stated in the section "Development and Application of Groundwater Flow and Particle-Tracking Models," the steady-state simulations are not 
intended to exactly match transient hydrologic conditions and transport characteristics in the karstic Edwards aquifer system but rather are meant to be used as a tool to better understand the movement of contaminants to PSWs. The effects of storage, not accounted for in steady-state simulations, on traveltimes are likely to be minimal because the water released from storage is ultimately derived from recharge and is not a different source of water (Leon Kauffman, U.S. Geological Survey, written commun., 2008); that is, the water released from storage is derived from recharge, with an age corresponding to the time that recharge occurred, not a new source of water that would have a different age.

A comparison between simulated particle ages and apparent groundwater ages might be more uncertain for the karstic Edwards aquifer than for other types of aquifers for a number of reasons. Hydrogeologically, groundwater in the Edwards aquifer undergoes appreciable mixing. Also, the apparent ages themselves are an interpretation of tracer concentrations, and that interpretation is based on some assumed hydrogeologic conceptual model. The apparent ages used for comparison with the simulated particle ages for this study are based on a piston-flow geochemical model, which may not be a valid model for karst aquifers (Musgrove and others, 2011). This is further indicated by a lack of good correlation between the age-tracer (tritium) and other independent geochemical tracers that provide insight into the relative residence time of water in the aquifer. Additional information on the mean apparent age of groundwater derived from age-tracer concentrations is discussed in Musgrove and others (2009) and Musgrove and others (2011).

Results from the local-scale model described herein should be interpreted generally and are best suited for comparative analysis rather than for prediction at this location. The local-scale model was developed to portray and test the conceptual understanding of the aquifer system. The model was not expected to reproduce the natural system or transient hydrologic conditions in detail but was intended to represent its dominant characteristics. This is especially true in aquifers with karst features where there is an extreme difference in aquifer properties at scales much smaller than the minimum representation in the numerical model. Although the simulated ACR for the selected PSW and nearby well nests in San Antonio likely do not represent the true areas contributing recharge, they are a useful tool for delineating approximate areas that may serve as sources of groundwater recharging the wells and potential sources of contaminants at the time of recharge.

\section{Summary}

In 2006, a public-supply well (PSW) in San Antonio, Tex., was selected for intensive study to assess the vulnerability of PSWs in the Edwards aquifer to contamination by a variety of compounds. The construction and operational practices of this PSW (hereinafter, the "selected PSW") are representative of many PSWs that use the Edwards aquifer for supplying the population of San Antonio, which includes Bexar and Comal Counties. A total of six wells were installed in 2007-8 in two nests (with four wells in one nest and two wells in the other nest) oriented along one of the general directions of groundwater flow to the selected PSW to support a detailed analysis of physical and chemical conditions and processes affecting the water chemistry of the selected PSW. A local-scale, steady-state, three-dimensional numerical groundwater-flow model was developed and used in this study to evaluate the movement of water and solutes from recharge areas to the selected PSW. The uniformly spaced finitedifference grid used to spatially discretize the model area for the local-scale model has 300 rows and 350 columns and is rotated 35 degrees counterclockwise from horizontal. The dimensions of the grid cells are uniformly $201.2 \mathrm{~m}$ along rows and columns. The local-scale model has 92 layers, each with a uniform thickness of $8 \mathrm{~m}$ and top and bottom surfaces that dip downward to the south and east with a uniform slope, following the general slope of the top of the Edwards aquifer. The local-scale model includes 12 hydrogeologic units (HGUs), whose properties are defined by using the MODFLOW Hydrogeologic-Unit Flow (HUF) Package. The geometry of the HGUs is defined independently of the model layers, with the model-layer geometry being superimposed on the defined HGUs. In the local-scale model, one to three HGUs are present in each active model cell. HGU5 and HGU9 ("conduit" HGUs) represent hydrogeologic units with high hydraulic conductivities (one or more orders of magnitude higher than for the other HGUs) and low effective porosities $\left(10^{-4}\right)$ that are intended to simulate fast flow paths attributable to karst features.

Numerous faults with varying vertical displacements occur in the local-scale model area. The extensive faulting results in the juxtaposition of HGUs with differing hydraulic properties and has appreciable effects on groundwater flow in the Edwards aquifer. The use of the MODFLOW HUF Package results in different HGUs with differing hydraulic properties being frequently juxtaposed in adjacent cells in the localscale model, allowing water particles to move between HGUs within the same model layer. The MODFLOW HorizontalFlow Barrier (HFB) Package was used to explicitly simulate faults in the local-scale model.

Boundary conditions for the local-scale model include specified fluxes entering or exiting the model area at the boundaries. In the local-scale model, specified fluxes are used for boundary conditions on all sides and layers of the model, except for layers that are inactive at the model boundary or whose thickness includes only HGU1. Water flowing across the boundary into HGU1 is assumed to be negligible. A nonzero flux boundary was used for the northern model boundary to account for inflow from the adjacent Trinity aquifer. The fluxes from an existing two-layer diffuse-flow rediscretized regional Edwards aquifer model were apportioned among the 92 layers of the local-scale model on the 
basis of the cumulative transmissivities of the HGUs present in each boundary cell. The net boundary flux for the western local-scale model boundary is into the local-scale model area $\left(986,034\right.$ cubic meters per day $\left.\left[\mathrm{m}^{3} / \mathrm{d}\right]\right)$, while the net boundary fluxes for the eastern and southern local-scale model boundaries are out of the local-scale model area (782,013 and 327,430 $\mathrm{m}^{3} / \mathrm{d}$, respectively).

Stresses simulated in the local-scale model include recharge from precipitation, discharge from pumping, and discharge to springs. Recharge to the Edwards aquifer occurs primarily by seepage from streams to the aquifer in the recharge zone. Additional recharge is from infiltration of rainfall in the interstream areas of the recharge zone. Eighty-five percent of the recharge was applied to streambed cells, and the remaining 15 percent was applied to the interstream area cells. No recharge was applied to cells outside the recharge zone. Discharge from the Edwards aquifer includes withdrawals by wells and springflow. Average withdrawal rates by wells for 2001 were distributed spatially within the model grid for the local-scale model on the basis of the well locations. The vertical assignment of withdrawals to a model layer was done on the basis of the percentage of the screened interval in each of the model layers and the transmissivity of the HGUs present in each model layer. The springs were simulated in the model by using the MODFLOW Drain Package.

The aquifer hydraulic properties specified in the localscale model - horizontal hydraulic conductivity and horizontal and vertical anisotropy - were defined by using the MODFLOW HUF Package. The simulated horizontal hydraulic conductivities for the local-scale model include a base horizontal hydraulic conductivity that varies by HGU and additional zones and values of horizontal hydraulic conductivity that are the same for multiple HGUs. Horizontal hydraulic conductivity zones, in addition to the base horizontal hydraulic conductivity zone (zone 1), include (1) zones of high horizontal hydraulic conductivity through the center of the confined part of the aquifer and near the northern boundary of the freshwater/saline-water transition zone, (2) zones of comparatively high horizontal hydraulic conductivity in the recharge zone underlying streambeds, and (3) zones of differing horizontal hydraulic conductivity near the boundary between the recharge zone and the confined part of the Edwards aquifer. Six zones of horizontal anisotropy are simulated in the local-scale model. The confined part of the Edwards aquifer composes one of the horizontal anisotropy zones, and five of the zones are delineated in the recharge zone of the aquifer. Uniform vertical anisotropy values were applied to each of the 12 simulated HGUs.

Particle tracking was performed by using MODPATH and was used to compute flow paths and advective traveltimes throughout the model area and to delineate the areas contributing recharge (ACR) and zones of contribution (ZOCs) for the selected PSW and the two monitoring well nests (Timberhill and Zarzamora). Calculated flux-weighted concentrations of the age-tracer tritium reaching the well were compared with measured concentrations to evaluate the adequacy of the local-scale model to simulate traveltimes and flow paths for potential contaminants. To calculate concentrations of the age-tracer tritium at the selected PSW and monitoring wells, particle tracking was used to obtain a distribution of particle ages that were then associated with a local tritium input function. A backward-tracking approach was used in MODPATH to obtain the particle-age distributions. Along with output from the local-scale model, the MODPATH simulations required effective porosity values to calculate groundwaterflow velocities. Changes to input effective porosity values change computed traveltimes from recharge areas to discharge areas (PSWs) in direct proportion to changes in effective porosity. Initial values of 0.01 for the HGUs with comparatively high hydraulic conductivities, 0.001 for the HGUs with comparatively low hydraulic conductivities, and 0.0001 for the two simulated conduit HGUs were specified in the local-scale model.

The local-scale model was calibrated for steady-state conditions. Average stresses (recharge and pumpage) during 2001, a representative year for the recent time period (200010 ), were used to simulate steady-state conditions. Groundwater-flow-model and particle-tracking calibration was evaluated by using 84 groundwater-level altitudes and 13 tritium concentrations. Overall, 70 parameters were used to define the simulation, including those for horizontal hydraulic conductivity, horizontal and vertical anisotropy, drain and fault hydraulic conductances, and effective porosity. The local-scale model was calibrated by using systematic manual calibration and by using the parameter-estimation code PEST. The parameters (1) vertical anisotropy for HGU2, HGU5, HGU9, and HGU11, (2) horizontal anisotropy for HANI zone 5, and (3) horizontal hydraulic conductivity for HK zones 15 and 17, with PEST-computed composite sensitivities greater than 70 (no units), are the most sensitive parameters in the simulation. Parameters with composite sensitivities equal to or less than 10 (no units) are effective porosities for all HGUs other than HGU9.

Model parameter values were varied during model calibration by using systematic manual calibration and PEST simulations to minimize the difference between modelcomputed and measured water-level altitudes, spring discharges, and age-tracer (tritium) concentrations. As a result of the steady-state calibration, the drain hydraulic conductance for San Antonio Springs was decreased by about 26 percent, and the drain hydraulic conductance for San Pedro Springs was increased by about 55 percent. The hydraulic conductances for HFB1, HFB2, and HFB3 were reduced by four to seven orders of magnitude compared to the initial values. The low calibrated effective porosities of about $10^{-4}$ (dimensionless) for the conduit HGUs indicate that the flow occurs in only a small percentage of the total volume of the aquifer, which is consistent with the concept of flow through conduits.

The calibrated steady-state simulation generally reproduces the spatial distribution of measured water-level altitudes. Simulated water-level altitudes were within $9.0 \mathrm{~m}$ 
of measured water-level altitudes at 74 of the 84 wells used as targets for the local-scale model for the calibrated steady-state simulation and was less than $3.0 \mathrm{~m}$ at 42 of the 84 wells. The overall mean absolute difference between simulated and measured water-level altitudes is $4.2 \mathrm{~m}$. The mean algebraic difference between simulated and measured water-level altitudes is $1.9 \mathrm{~m}$, indicating that simulated water-level altitudes are on an overall basis slightly lower than measured water-level altitudes. The simulated springflow for San Antonio Springs was 7.7 percent greater and for San Pedro Spring was 4.2 percent less than the median measured springflow.

Simulated age-tracer (tritium) concentrations were generally in good agreement with measured values in wells in the model area. Simulated tritium concentrations were within 0.35 tritium units (TU) of measured tritium concentrations for the 13 tritium observations (hereinafter, the "local-scale study tritium observations") from 10 wells (hereinafter, the "local-scale study wells") used as observations in PEST simulations to calibrate the local-scale model. Simulated tritium concentrations were within 3.52 TU of measured tritium concentrations for an additional 42 tritium observations (hereinafter, the "NAWQA tritium observations") from 29 NAWQA wells (hereinafter, the "NAWQA wells") not used as observations in the PEST simulations. The mean absolute difference between simulated and measured tritium concentrations for the local-scale study wells is $0.11 \mathrm{TU}$, and the mean algebraic difference is -0.04 TU. Simulated tritium concentrations were within $0.14 \mathrm{TU}$ of measured concentrations for 11 of the 13 local-scale study tritium observations. The mean absolute differences between simulated and measured tritium concentrations, grouped by the sampling location (at the wellhead) or sampling depth (shallow, intermediate, or deep), are similar among values grouped as wellhead, intermediate, or deep observations $(0.09,0.06$, and $0.11 \mathrm{TU}$, respectively) but are higher for the shallow grouping (0.23). Simulated tritium concentrations in the selected PSW during November 2007 were within 0.09 TU of the measured concentrations, with the exception of the shallow-depth observation. The vertical pattern in the measured tritium concentrations for the depth-dependent sampling in the selected PSW has the highest concentration for the shallow-depth observation, the lowest concentration for the intermediate-depth observation, and the middle concentration for the deep-depth observation. The simulated concentrations follow the pattern for the intermediate and deep observations but not for the shallow-depth observation. Poor matches between measured and simulated tritium concentrations might be a result of model limitations, such as inexact representations of karst features and their placement and the assumption of steady-state flow.

The simulated potentiometric surface was generally representative of the measured potentiometric surface in the local-scale model area. Water in the local-scale model flowed from the recharge zone toward the south and southeast into the confined zone. Water-level altitudes decreased from north to south, from north to southeast, and from west to east across the local-scale model area, and were in generally good agreement with the observed flow directions. Comparatively large simulated water-level changes coincide with the locations of large-displacement faults in the western part of the local-scale study area and in west-central Bexar County, consistent with measured water-level altitudes.

The steady-state simulation water budget indicates that recharge occurring in the local-scale study area accounts for 31.8 percent of the sources of water to the Edwards aquifer in the local-scale model area and that inflow through the model boundaries contributes 68.2 percent. Most of the flow into the local-scale model area through the model boundaries occurs through the western and southern boundaries, 58.2 and 39.6 percent, respectively. The largest discharges from the Edwards aquifer in the local-scale model area are boundary outflow (71.4 percent) and withdrawals by wells (24.9 percent). Most of the flow out of the local-scale model area through the model boundaries occurs through the southern and eastern boundaries, 54.2 and 39.6 percent, respectively. Springflow from San Antonio and San Pedro Springs contribute a small amount (3.7 percent) to the total discharge.

The simulated ZOCs for the selected PSW, Timberhill well nest, and Zarzamora well nest extend to the north, northeast, and northwest from each site in the confined zone of the aquifer into the recharge zone. The "patchy" (discontinuous) appearance of the ACR probably represents different simulated flow paths of water particles traversing different HGUs with widely differing hydraulic conductivities and effective porosities. The ACR for the selected PSW has the greatest extent, from the San Antonio River on the east to the Medina River on the west. The ACR for the Timberhill well nest (located northwest of the selected PSW) has the least extent, encompassing approximately the western one-half of the ACR for the selected PSW. The ACR for the Zarzamora well nest (located northeast of the selected PSW) is intermediate in its extent, encompassing approximately the eastern two-thirds of the ACR for the selected PSW.

Simulated particle ages ranged from less than 1 day to more than 1,900 years in the 10 local-scale study wells (13 local-scale study tritium observations). Simulated particle ages ranged from less than 1 day to more than 14,000 years in the 29 NAWQA wells (42 NAWQA tritium observations). The simulated particle ages for the local-scale study tritium observations representing selected well depths (shallow, intermediate, and deep) ranged from less than 1 day to 621 years. The minimum (youngest) particle ages for the selected PSW and the Zarzamora well nest were for the deep well depth, while the youngest particle age for the Timberhill well nest was for the intermediate well depth. The maximum (oldest) particle age for the Zarzamora well nest was for the shallow well depth, while the oldest particle ages for the selected PSW and the Timberhill well nest were for the deep well depth. The wellhead or composite mean particle ages in the 10 local-scale study wells (13 local-scale study tritium observations) ranged from 3.7 to 7.6 years and was youngest for the Timberhill well 
nest and oldest for the Zarzamora well nest. The mean particle age in the 29 NAWQA wells (42 NAWQA tritium observations) was 42 years, about 2.8 times greater than the maximum mean particle age for the 10 local-scale study wells.

The simulated mean particle ages for the tritium observations representing selected well depths (shallow, intermediate, and deep) ranged from 2.5 to 15 years. The minimum (youngest) mean particle ages for the selected PSW and the Timberhill well nest were for the intermediate well depth, while the youngest mean particle age for the Zarzamora well nest was for the intermediate and deep well depths. The maximum (oldest) mean particle ages for the selected PSW and the Zarzamora well nest were for the shallow well depth. The mean of simulated particle ages for tritium observations representing well depths open to the conduit HGUs was 3.8 years, whereas the mean of simulated particle ages for tritium observations representing well depths not open to the conduit HGUs was 9.6 years.

In a model-forecasting exercise, slug inputs of a hypothetical contaminant were used to examine the range in lag times, dilution, and degradation that might be expected at the selected PSW. The hypothetical contaminant was introduced over the ACR for the selected PSW continuously for 30 years, and simulations with no contaminant degradation and with contaminant degradation at a first-order reaction kinetics degradation rate of 0.1 per year ( 10 percent per year) were conducted. For both simulations, concentrations at the selected PSW began to rise within 1 year after loading began and rose quickly to reach 50 percent of peak concentration in 3 (with nondegradation) or 4 years (with degradation). Concentrations continued to rise for both simulations until peak concentrations were reached at the end of the input period of 30 years. Once the input was stopped after 30 years, both simulations responded with a rapid drop in concentration. However, 32 and 12 years were required for the nondegradation and withdegradation simulations, respectively, to flush 99 percent of the hypothetical contaminant and achieve near background conditions.

The effect of short-circuit pathways, for example karst conduits, in the flow system on the movement of young water to the selected PSW could greatly alter contaminant arrival times compared to what might be expected from advection in a system without short circuiting. In the forecasting exercise, the simulated concentrations showed rapid initial response at the beginning and end of chemical input, followed by more gradual response as older water moved through the system. The nature of karst groundwater flow, where flow predominantly occurs via conduit flow paths, could lead to relatively rapid water quality responses to land-use changes. Results from the forecasting exercise and other similar exercises indicate that timescales for change in the quality of water from the selected PSW could be on the order of a few years to decades for land-use changes that occur over days to decades, which has implications for source-water protection strategies that rely on land-use change to achieve water-quality objectives.

\section{References Cited}

Abbott, P.L., and Woodruff, C.M., Jr., 1986, eds., The Balcones escarpment-Geology, hydrology, ecology and social development in central Texas: Geological Society of America.

Anderman, E.R., and Hill, M.C., 2000, MODFLOW-2000, the U.S. Geological Survey modular ground-water modelDocumentation of the hydrogeologic-unit flow (HUF) package: U.S. Geological Survey Open-File Report 00-342, 89 p.

Anderson, M.P., and Woessner, W.W., 1992, Applied groundwater modeling: Academic Press, Inc., New York, 381 p.

Atkinson, T.C., 1977, Diffuse flow and conduit flow in limestone terrain in the Mendip Hills, Somerset (Great Britain): Journal of Hydrology, v. 35, no. 1/2, p. 93-110.

Atkinson, T.C., and Smart, P.L., 1981, Artificial tracers in hydrogeology, in A survey of British hydrogeology 1980: London, The Royal Society, p. 173-190.

Barker, R.A., and Ardis, A.F., 1996, Hydrogeologic framework of the Edwards-Trinity aquifer system, west-central Texas: U.S. Geological Survey Professional Paper 1421-B, 61 p.

Bauer, S., Liedl, R., and Sauter, M., 2003, Modeling of karst aquifer genesis - Influence of exchange flow: Water Resources Research, v. 39, no. 10, p. 1285-1297.

Birk, Steffen, Bauer, Sebastian, Liedl, Rudolf, and Sauter, Martin, 2003, Coupling a pipe-network to MODFLOW to predict the evolution of karst aquifers, in Poeter, E.P., Zheng, C., Hill, M.C., and Doherty, John, eds., MODFLOW and more 2003 - Understanding through modeling, Golden, Colo., September 16-19, 2003, Proceedings: Colorado School of Mines, p. 65-69.

Bomar, G.W., 1994, Texas Weather: Austin, Texas, University of Texas Press, 287 p.

Brune, Gunnar, 1975, Major and historical springs of Texas: Texas Water Development Board Report 189, 103 p. [Available from National Technical Information Service, Springfield, VA 22161 as NTIS report PB-296 524/2.]

Burow, K.R., Jurgens, B.C., Kauffman, L.J., Phillips, S.P., Dalgish, B.A., and Shelton, J.L., 2008, Simulations of ground-water flow and particle pathline analysis in the zone of contribution of a public-supply well in Modesto, eastern San Joaquin Valley, California: U.S. Geological Survey Scientific Investigations Report 2008-5035, 41 p. Available at http://pubs.usgs.gov/sir/2008/5035.

Chapelle, F.H., and Bradley, P.M., 1999, Selecting remediation goals by assessing the natural attenuation capacity of ground-water systems, in Morganwalp, D.W., and Buxton, 
H.T., eds., Subsurface Contamination from Point Sources, U.S. Geological Survey Toxic Substances Hydrology Program, Charleston, South Carolina, March 8-12, 1999, Proceedings of the Technical Meeting: U.S. Geological Survey Water-Resources Investigations Report 99-4018C, v. 3, p. 7-19.

Clark, A.K., and Journey, C.A., 2006, Flow paths in the Edwards aquifer, northern Medina and northeastern Uvalde Counties, Texas, based on hydrologic identification and geochemical characterization and simulation: U.S. Geological Survey Scientific Investigations Report 2006-5200, 48 p.

Clark, A.K., and Morris, R.R., 2011, Geologic framework and hydrogeologic characteristics in the southern part of the Rancho Diana Natural Area, northern Bexar County, Texas, 2008-10: U.S. Geological Survey Scientific Investigations Report 2011-5069, 19 p.

Crandall, C.A., Kauffman, L.J., Katz, B.G., Metz, P.A., McBride, W.S., and Berndt, M.P., 2009, Simulations of groundwater flow and particle tracking analysis in the area contributing recharge to a public-supply well near Tampa, Florida, 2002-05, U.S. Geological Survey Scientific Investigations Report 2008-5231, 53 p.

Doherty, John, 2005, PEST-Model-independent parameter estimation user manual, 5th edition: Watermark Numerical Computing. [Variously paged.]

Eberts, S.M., Erwin, M.L., and Hamilton, P.A., 2005, Assessing the vulnerability of public-supply wells to contamination from urban, agricultural, and natural sources: U.S. Geological Survey Fact Sheet 2005-3022, 4 p.

Edwards Aquifer Authority, 2009, Edwards Aquifer Authority hydrologic data report for 2008: San Antonio, Edwards Aquifer Authority Report No. 09-02, 193 p.

Edwards Aquifer Research and Data Center, 2010, Threatened and endangered species in the Edwards aquifer system: accessed January 29, 2010, at http://www.eardc.txstate.edu/ endangered.html.

Elliott, W.R., and Veni, George, eds., 1994, The caves and karst of Texas - Guidebook for the 1994 convention of the National Speleological Society with emphasis on the southwestern Edwards Plateau: Huntsville, Ala., National Speleological Society, $342 \mathrm{p}$.

Environmental Simulations, Inc., 2007, Guide to using Groundwater Vistas, Version 5: Reinholds, Pa., Environmental Simulations, Inc., 372 p.

Ewing, T.E., 1991, Structural framework, in Salvador, Amos, ed., The Gulf of Mexico Basin: Geological Society of America, Geology of North America, v. J, p. 31-52.
Fahlquist, Lynne, and Ardis, A.F., 2004, Quality of water in the Trinity and Edwards aquifers, south-central Texas, 1996-98: U.S. Geological Survey Scientific Investigations Report 2004-5201, 17 p.

Focazio, M.J., Reilly, T.E., Rupert, M.G., and Helsel, D.R., 2002, Assessing ground-water vulnerability to contamination-Providing scientifically defensible information for decision makers: U.S. Geological Survey Circular 1224, $33 \mathrm{p}$.

Franke, O.L., Reilly, T.E., and Bennett, G.D., 1984, Definition of boundary and initial conditions in the analysis of saturated ground-water flow systems-An introduction: U.S. Geological Survey Open-File Report 84-458, 26 p.

Franke, O.L., Reilly, T.E., Pollock, D.W., and LaBaugh, J.W., 1998, Estimating areas contributing recharge to wellsLessons from previous studies: U.S. Geological Survey Circular 1174, 14 p.

Freeze, R.A., and Cherry, J.A., 1979, Groundwater: PrenticeHall, Inc., New Jersey, 604 p.

Gale, S.J., 1984, The hydraulics of conduit flow in carbonate aquifers: Journal of Hydrology, v. 70, p. 309-327.

Garza, Sergio, 1968, Aquifer characteristics from well-field production records, Edwards Limestone, San Antonio area, Texas: Tucson, University of Arizona, master's thesis, 46 p.

George, W.O., 1952, Geology and ground-water resources of Comal County, Texas: U.S. Geological Survey WaterSupply Paper 1138, 126 p.

Groschen, G.E., 1996, Hydrogeologic factors that affect the flowpath of water in selected zones of the Edwards aquifer, San Antonio region, Texas: U.S. Geological Survey WaterResources Investigations Report 96-4046, 73 p.

Halihan, Todd, Mace, R.E., and Sharp, J.M., 2000, Flow in the San Antonio segment of the Edwards aquifer-Matrix, fractures, or conduits?, in Sasowsky, I.D., and Wicks, C.M., Groundwater flow and contaminant transport in carbonate aquifers: Brookfield, Vt., A.A. Balkema, p. 129-146.

Hamilton, J.M., Johnson, S., Esquilin, R., Thompson, E.L., Luevano, G., Wiatrek, A., Mireles, J., Gloyd, T., Sterzenback, J., Hoyt, J.R., and Schindel, G., 2003, Edwards Aquifer Authority hydrogeological data report for 2002: San Antonio, Edwards Aquifer Authority, 134 p. [Available online at www.edwardsaquifer.org.]

Harbaugh, A.W., Banta, E.R., Hill, M.C., and McDonald, M.G., 2000, MODFLOW-2000, the U.S. Geological Survey modular ground-water model-User guide to modularization concepts and the ground-water flow process: U.S. Geological Survey Open-File Report 00-92, 121 p.

Haugh, C.J., 2006, Hydrogeology and simulation of groundwater flow at Arnold Air Force Base, Coffee and Franklin 
Counties, Tennessee-2002 update: U.S. Geological Survey Scientific Investigations Report 2006-5157, 76 p.

Hauwert, N.M., Johns, D.A., and Sharp, J., 2002, Evidence of discrete flow in the Barton Springs segment of the Edwards aquifer, in Martin, J.B., Wicks, C.M., and Sasowsky, I.D., eds., Hydrogeology and biology of post-Paleozoic carbonate aquifers: Karst Waters Institute, Special Publication 7, p. $62-167$.

Hauwert, N.M., Sansom, J.W., Jr., Johns, D.A, and Aley, T.A., 2002, Groundwater tracing study of the Barton Springs segment of the Edwards aquifer, southern Travis and northern Hays Counties, Texas: Austin, Barton Springs/Edwards Aquifer Conservation District and City of Austin Watershed Protection Department, $8 \mathrm{p}$.

Heath, R.C., 1983, Basic ground-water hydrology: U.S. Geological Survey Water-Supply Paper 2220, 84 p.

Hill, M.C., 1998, Methods and guidelines for effective model calibration: U.S. Geological Survey Water-Resources Investigations Report 98-4005, $90 \mathrm{p}$.

Holt, C.L.R., Jr., 1959, Geology and ground-water resources of Medina County, Texas: U.S. Geological Survey WaterSupply Paper 1422, 213 p. [Also published as Texas Board of Water Engineers Bulletin 5601, 278 p., 1956.]

Homer, C.G., Huang, C., Yang, L., Wylie, B.K., and Coan, M.J., 2001, National Land Cover Database 2001 (NLCD 2001): U.S. Geological Survey, EROS Data Center, MRLC Project, Sioux Falls, S. Dak., accessed October 2007 at http://seamless.usgs.gov/.

Hovorka, S.D., Dutton, A.R., Ruppel, S.C., and Yeh, J.S., 1996, Edwards aquifer ground-water resources - Geologic controls on porosity development in platform carbonates, South Texas: Austin, University of Texas, Bureau of Economic Geology Report of Investigations 238, 75 p.

Hovorka, S.D., Mace, R.E., and Collins, E.W., 1998, Permeability structure of the Edwards aquifer, south Texas-Implications for aquifer management: Austin, University of Texas, Bureau of Economic Geology Report of Investigations 250, $55 \mathrm{p}$.

Hovorka, S.D., Phu, T., Nicot, J.P., and Lindley, A., 2004, Refining the conceptual model for flow in the Edwards aquifer-Characterizing the role of fractures and conduits in the Balcones fault zone segment: Contract report to Edwards Aquifer Authority, 53 p., available at http:// www.edwardsaquifer.org/pdfs/Reports/AS\%20Reports/ Flowpath\%20Modeling\%20Studies/Fracture-Conduit $\% 20$ Study/BEG\%20-\%20Frac-Con\%20Rpt.pdf.

Hovorka, S.D., Ruppel, S.C., Dutton, A.R., and Yeh, J.S., 1993, Edwards aquifer storage assessment, Kinney County to Hays County, Texas: San Antonio, Edwards Underground Water District, 109 p.
Huntoon, P.W., 1995, Is it appropriate to apply porous media groundwater circulation models to karstic aquifers?, in El-Kadi, A.I., ed., Groundwater models for resources analysis and management: Boca Raton, Lewis Publishers, p. 339-358.

International Atomic Energy Agency/World Meteorological Organization, 2008, Global network of Isotopes in Precipitation, the GNIP database, accessed July 2008 at http://www.iaea.org/water.

Johnson, S.B., Schindel, G.M., and Hoyt, J.R., 2002, Groundwater chemistry changes during a recharge event in the karstic Edwards aquifer, San Antonio, Texas: Geological Society of America, online abstract 186-8.

Klemt, W.B., Knowles, T.R., Edler, G.R., and Sieh, T.W., 1979, Ground-water resources and model applications for the Edwards (Balcones fault zone) aquifer in the San Antonio region: Texas Water Development Board Report $239,88 \mathrm{p}$.

Klimchouk, A.B., 2008, Principal characteristics of hypogenic speleogenesis: Geological Society of America 2008 Annual Convention Program Abstracts, Houston, Texas, October 5-9, 2008, available at http://a-c-s.confex.com/ crops/2008am/webprogram/Paper49762.html.

Kuniansky, E.L., Fahlquist, Lynne, and Ardis, A.F., 2001, Traveltimes along selected flow paths of the Edwards Aquifer, Central Texas, in Kuniansky, E.L., ed., 2001, U.S. Geological Survey Karst Interest Group Proceedings, St. Petersburg, Florida, February 13-16, 2001: USGS WaterResources Investigations Report 01-4011, p. 69-77.

Larkin, T.J., and Bomar, G.W., 1983, Climatic atlas of Texas: Texas Department of Water Resources LP-192, 151 p.

LBG-Guyton Associates, 1995, Edwards aquifer groundwater divides assessment, San Antonio region, Texas: San Antonio, Edwards Underground Water District Report 95-01, $35 \mathrm{p}$.

Lindgren, R.J., 2006, Diffuse-flow conceptualization and simulation of the Edwards aquifer, San Antonio region, Texas: U.S. Geological Survey Scientific Investigations Report 2006-5319, 47 p.

Lindgren, R.J., Dutton, A.R., Hovorka, S.D., Worthington, S.R.H., and Painter, Scott, 2004, Conceptualization and simulation of the Edwards aquifer, San Antonio region, Texas: U.S. Geological Survey Scientific Investigations Report 2004-5277, 143 p.

Lindgren, R.J., Taylor, C.J., and Houston, N.A., 2009, Description and evaluation of numerical groundwater flow models for the Edwards aquifer, south-central Texas: U.S. Geological Survey Scientific Investigations Report 20095183, $25 \mathrm{p}$. 
Lindgren, R.J., Houston, N.A., Musgrove, M., Fahlquist, L., and Kauffman, L.J., 2011, Hydrogeologic setting and groundwater flow simulations of the south-central Texas regional study area, Texas, section 3 of Eberts, S.M., ed., Hydrogeologic settings and ground-water flow simulations for regional studies of the transport of anthropogenic and natural contaminants to public-supply wells: U.S. Geological Survey Professional Paper 1737-B, p. 3-1 to 3-51.

Lohman, S.W., 1972, Definitions of selected ground-water terms-Revisions and conceptual refinements: U.S. Geological Survey Water-Supply Paper 1988, 21 p.

Long, A.T., 1962, Ground-water geology of Edwards County, Texas: Texas Water Commission Bulletin 6208, 123 p.

Lozo, F.E., Jr., and Smith, C.I., 1964, Revision of Comanche Cretaceous stratigraphic nomenclature, southern Edwards Plateau, southwest Texas: Gulf Coast Association of Geological Societies Transactions, v. 14, p. 285-306.

Mace, R.E., and Hovorka, S.D., 2000, Estimating porosity and permeability in a karstic aquifer using core plugs, well tests, and outcrop measurements, in Sasowsky, I.D., and Wicks, C.M., Groundwater flow and contaminant transport in carbonate aquifers: Brookfield, Vt., A.A. Balkema, p. 93-111.

Mace, R.E., Chowdhury, A.H., Anaya, Roberto, and Way, S.C., 2000, Groundwater availability of the Trinity aquifer, Hill Country area, Texas-Numerical simulations through 2050: Texas Water Development Board Report 353, 169 p.

Mace, R.E., Fisher, R.S., Welch, D.M., and Parra, S.P., 1997, Extent, mass, and duration of hydrocarbon plumes from leaking petroleum storage tank sites in Texas: Austin, University of Texas, Bureau of Economic Geology Geological Circular 01, 52 p.

Maclay, R.W., 1995, Geology and hydrology of the Edwards aquifer in the San Antonio area, Texas: U.S. Geological Survey Water-Resources Investigations Report 95-4186, $64 \mathrm{p}$.

Maclay, R.W., and Land, L.F., 1988, Simulation of flow in the Edwards aquifer, San Antonio region, Texas, and refinements of storage and flow concepts: U.S. Geological Survey Report Water-Supply Paper 2336-A, 48 p.

Maclay, R.W., and Rettman, P.L., 1973, Regional specific yield of the Edwards aquifer and associated limestones in the San Antonio, Texas, area: U.S. Geological Survey OpenFile Report 73-172, 14 p. [Also published as Edwards Underground Water District Report, 10 p., 1973.]

Maclay, R.W., and Small, T.A., 1976, Progress report on geology of the Edwards aquifer, San Antonio area, Texas, and preliminary interpretation of borehole geophysical and laboratory data on carbonate rocks: U.S. Geological Survey Open-File Report 76-627, 65 p.
Maclay, R.W., and Small, T.A., 1983, Hydrostratigraphic subdivisions and fault barriers of the Edwards aquifer, south central Texas: Journal of Hydrology, v. 61, no. 1-3, p. 127-146.

Maclay, R.W., and Small, T.A., 1984, Carbonate geology and hydrology of the Edwards aquifer in the San Antonio area, Texas: U.S. Geological Survey Open-File Report 83-537, $72 \mathrm{p}$. [Also published as Texas Water Development Board Report 296, 90 p., 1986.]

McMahon, P.B., Burow, K.R., Kauffman, L.J., Eberts, S.M., Böhlke, J.K., and Gurdak, J.J., 2008, Simulated response of water quality in public supply wells to land use change: Water Resources Research, v. 44, W00A06, doi:10.1029/2007WR006731.

Michel, R.M., 1989, Tritium deposition in the continental United States, 1953-1983: U.S. Geological Survey WaterResources Investigations Report 89-4072, 46 p.

Musgrove, M., Fahlquist, L., Houston, N.A., Lindgren, R.J., and Ging, P.B., 2009, Geochemical evolution processes and water-quality observations based on results of the National Water-Quality Assessment Program in the San Antonio segment of the Edwards aquifer, 1996-2006: U.S. Geological Survey Scientific Investigations Report 2010-5129, 93 p. (Appendixes available online only at http://pubs.usgs.gov/ $\operatorname{sir} / 2010 / 5129 /$.

Musgrove, M., Fahlquist, L., Stanton, G.P., Houston, N.A., and Lindgren, R.J., 2011, Hydrogeology, chemical characteristics, and water sources and pathways in the zone of contribution of a public-supply well in San Antonio, Texas: U.S. Geological Survey Scientific Investigations Report 2011-5146, 194 p.

National Oceanic and Atmospheric Administration, National Climatic Data Center, 2002, Monthly station normals of temperature, precipitation, and heating and cooling degree days, 1971-2000, Texas: U.S. Department of Commerce, v. 97, no. 81. [Variously paged.]

Ogden, A.E., Quick, R.A., Rothermel, S.R., and Lundsford, D.L., 1986, Hydrological and hydrochemical investigation of the Edwards aquifer in the San Marcos area, Hays County, Texas: San Marcos, Tex., Edwards Aquifer Research and Data Center, $364 \mathrm{p}$.

Osenbrück, K., Fiedler, S., Knöller, K., Weise, S.M., Sültenfuß, J., Oster, H., and Strauch, G., 2006, Timescales and development of groundwater pollution by nitrate in drinking water wells of the Jahna-Aue, Saxonia, Germany, Water Resources Research, v. 42, W12416, doi:10.1029/2006WR004977.

Painter, Scott, Jiang, Yefang, and Woodbury, Allan, 2002, Edwards aquifer parameter estimation project final report: Southwest Research Institute. [Variously paged.] 
Palmer, A.N., 1991, Origin and morphology of limestone caves: Geological Society of America Bulletin, v. 103, p. 1-21.

Pavlicek, Dianne, Small, T.A., and Rettman, P.L., 1987, Hydrologic data from a study of the freshwater zone/saline water zone interface in the Edwards aquifer, San Antonio Region, Texas: U.S. Geological Survey Open-File Report 87-389, 108 p.

Peacock, D.C.P., and Sanderson, D.J., 1994, Geometry and development of relay ramps in normal fault systems: American Association of Petroleum Geologists Bulletin, v. 78, no. 2, p. 147-165.

Pollock, D.W., 1994, User's guide for MODPATH/ MODPATH-PLOT, version 3-A particle tracking postprocessing package for MODFLOW-The U.S. Geological Survey finite-difference ground-water flow model: U.S. Geological Survey Open-File Report 94-464, 248 p.

Puente, Celso, 1978, Method of estimating natural recharge to the Edwards aquifer in the San Antonio area, Texas: U.S. Geological Survey Water-Resources Investigations Report 78-10, 34 p.

Reilly, T.E., and Pollock, D.W., 1995, Effects of seasonal and long-term changes in stress on sources of water to wells: U.S. Geological Survey Water-Supply Paper 2445, 25 p.

Rock, G., and Kupfersberger, H., 2002, Numerical delineation of transient capture zones: Journal of Hydrology, v. 269, p. 134-149.

Rose, P.R., 1972, Edwards Group, surface and subsurface, central Texas: Austin, University of Texas, Bureau of Economic Geology Report of Investigations 74, 198 p.

Rothermel, S.R., Ogden, A.E., and Snider, C.C., 1987, Hydrochemical investigation of the Comal and Hueco Spring systems, Comal County, Texas: San Marcos, Edwards Aquifer Research and Data Center Report R1-87, $182 \mathrm{p}$.

San Antonio Water System, 2008, Water statistics, year ending December 31, 2008: Infrastructure Planning Department, San Antonio Water System. [Variously paged.]

Scanlon, B.R., Mace, R.E., Smith, Brian, Hovorka, S.D., Dutton, A.R., and Reedy, R.C., 2002, Groundwater availability of the Barton Springs segment of the Edwards aquifer, Texas-Numerical simulations through 2050: Austin, University of Texas, Bureau of Economic Geology, final report prepared for Lower Colorado River Authority under contract no. UTA99-0, 36 p.

Schindel, G.M., Johnson, S.B., Worthington, S.R.H., Alexander, E.C., Jr., Alexander, Scott, and Schnitz, Lewis, 2002, Groundwater flow velocities for the deep artesian portion of the Edwards aquifer, near Comal Springs, Texas, in Annual Meeting of the Geological Society of America,
Denver, Colo., October 27-30, 2002: Geological Society of America Abstracts with Programs, v. 34, no. 6, p. 347.

Schindel, G.M., Johnson, Steven, and Alexander, E.C., 2008, Hypogene processes in the Edwards aquifer in south-central Texas, a new conceptual model to explain aquifer dynamics, available at http://www.searchanddiscovery.com/ documents/2008/08188schindel/index.htm.

Schultz, A.L., 1992, Using geophysical logs in the Edwards aquifer to estimate water quality along the freshwater/ saline-water interface (Uvalde to San Antonio, Texas): San Antonio, Edwards Underground Water District Report 92-03, 47 p.

Schultz, A.L., 1993, Defining the Edwards aquifer freshwater/ saline-water interface with geophysical logs and measured data (San Antonio to Kyle, Texas): San Antonio, Edwards Underground Water District Report 93-06, 81 p.

Schultz, A.L., 1994, 1994 review and update of the position of the Edwards aquifer freshwater/saline-water interface from Uvalde to Kyle, Texas: San Antonio, Edwards Underground Water District report 94-05, $31 \mathrm{p}$.

Senger, R.K., and Kreitler, C.W., 1984, Hydrogeology of the Edwards aquifer, Austin area, Central Texas: Austin, University of Texas, Bureau of Economic Geology Report of Investigations 141, $35 \mathrm{p}$.

Shuster, E.T., and White, W.B., 1971, Seasonal fluctuations in the chemistry of limestone springs - A possible means for characterizing carbonate aquifers: Journal of Hydrology, v. 14 , p. $93-128$

Sieh, T.H., 1975, Edwards (Balcones fault zone) aquifer test well drilling investigation: Texas Water Development Board Report, 117 p.

Slade, R.M., Jr., Ruiz, Linda, and Slagle, Diana, 1985, Simulation of the flow system of Barton Springs and associated Edwards aquifer in the Austin area, Texas: U.S. Geological Survey Water-Resources Investigations Report 85-4299, 49 p.

Snow, D.T., 1969, Anisotropic permeability of fractured media: Water Resources Research, 5, p. 1,273-1,289.

Stein, W.G., 1993, Population and well distribution for the Edwards aquifer, in Kuniansky, E.L., ed., Man's Effect on Hydrologic Systems-Fall Meeting, Texas Section, Austin, Tex., December 10, 1993, Proceedings: American Water Resources Association, p. 17-22.

Texas Water Development Board, 2008, Historical Water Use Information, accessed February 28, 2007, at http://www. twdb.state.tx.us/wushistorical.

Thorkildsen, D.F., and McElhaney, P.D., 1992, Model refinement and applications for the Edwards (Balcones fault zone) aquifer in the San Antonio region, Texas: Texas Water Development Board Report 340, 33 p. 
Thrailkill, J., 1968, Chemical and hydrologic factors in the excavation of limestone caves: Geological Society of America Bulletin 79, p. 19-46.

Tomasko, David, Fisher, Ann-Marie, Williams, G.P., and Pentecost, E.D., 2001, A statistical study of the hydrologic characteristics of the Edwards aquifer: Chicago, Argonne National Laboratory, 38 p.

U.S. Army Corps of Engineers, 1965, Survey report on Edwards underground reservoir, Guadalupe, San Antonio, and Nueces Rivers and tributaries, Texas: U.S. Army Corps of Engineers, Fort Worth District and Texas, Edwards Underground Water District, 2 v.

U.S. Environmental Protection Agency, 2006, Region 6 water programs - Designated sole source aquifers: available at http://www.epa.gov/region6/water/swp/ssa/maps.htm.

Vauter, B.K., 1992, Geology and its influence on cavern development in an area surrounding Natural Bridge Caverns, Comal County, Texas: Geological Society of America Abstracts with Programs, v. 24, no. 1, p. 49.

Veni, George, 1988, The caves of Bexar County (2d ed.): Austin, University of Texas, Texas Memorial Museum Speleological Monograph 2, 300 p.

Veni, George, 1994, Geomorphology, hydrogeology, geochemistry, and evolution of the karstic lower Glen Rose aquifer, south-central Texas: University Park, Pa., Pennsylvania State University, Ph.D. dissertation, 749 p.

Veni, George, 1995, Revisiting the boundaries of the Edwards (Balcones fault zone) aquifer recharge zone, in Jordan,
W., and Jensen, R., eds., 24th Water for Texas Conference, College Station, Tex., January 26-27, 1995, Proceedings: Texas Water Resources Institute, p. 99-107.

Walker, L.E., 1979, Occurrence, availability, and chemical quality of ground water in the Edwards Plateau region of Texas: Texas Department of Water Resources Report 235, $346 \mathrm{p}$.

Waterreus, P.A., 1992, Hydrogeology of the Camp Bullis area, northern Bexar County, Texas: San Antonio, University of Texas, master's thesis, $186 \mathrm{p}$.

Woodruff, C.M., Jr., and Abbott, P.L., 1986, Stream piracy and evolution of the Edwards aquifer along the Balcones Escarpment, Central Texas, in Abbot, P.L., and Woodruff, C.M., Jr., eds., The Balcones escarpment - Geology, hydrology, ecology and social development in central Texas: Geological Society of America, p. 77-100.

Worthington, S.R.H., 1999, A comprehensive strategy for understanding flow in carbonate aquifers, in Palmer, A.N., Palmer, M.V., and Sasowsky, I.D., eds., Karst modeling: Karst Waters Institute, Special Publication 5, p. 30-37.

Worthington, S.R.H., 2001, Depth of conduit flow in unconfined carbonate aquifers: Geology, v. 29, p. 335-338.

Worthington, S.R.H., 2004, Conduits and turbulent flow in the Edwards aquifer: Worthington Groundwater, contract report to Edwards Aquifer Authority, San Antonio, Tex., 41 p., available at http://www.edwardsaquifer.org/pdfs/Reports/ AS\%20Reports/Flowpath\%20Modeling\%20Studies/ Conduits $\% 20$ and $\% 20$ Turbulent $\% 20$ Flow $\% 20$ in $\% 20$ the $\% 20$ Edwards\%20Aquifer\%20-\%20Worthington.pdf. 
Table 1. Summary of groundwater wells used in the local-scale model, San Antonio region, Texas.

[Hydrogeologic unit numbers refer to hydrogeologic units as follows: 1 is overburden, 2 is Georgetown, 3 is cyclic and marine, 4 is leached and collapsed, 5 is upper high $\mathrm{K}$ (conduit), 6 is regional dense, 7 is grainstone, 8 is Kirschberg evaporite, 9 is lower high $\mathrm{K}$ (conduit), 10 is dolomitic, 11 is basal nodular, 12 is Glen Rose (Trinity Group); WZ4W is wellhead sample for well WZ4; WZ4S is shallow depth-dependent sampling interval for well WZ4; WZ4I is intermediate depth-dependent sampling interval for well WZ4; WZ4D is deep depth-dependent sampling interval for well WZ4; WZ5W is wellhead sample for well WZ5; WZ6W is wellhead sample for well WZ6; WZ2W is wellhead sample for well WZ2; WZ3W is wellhead sample for well WZ3]

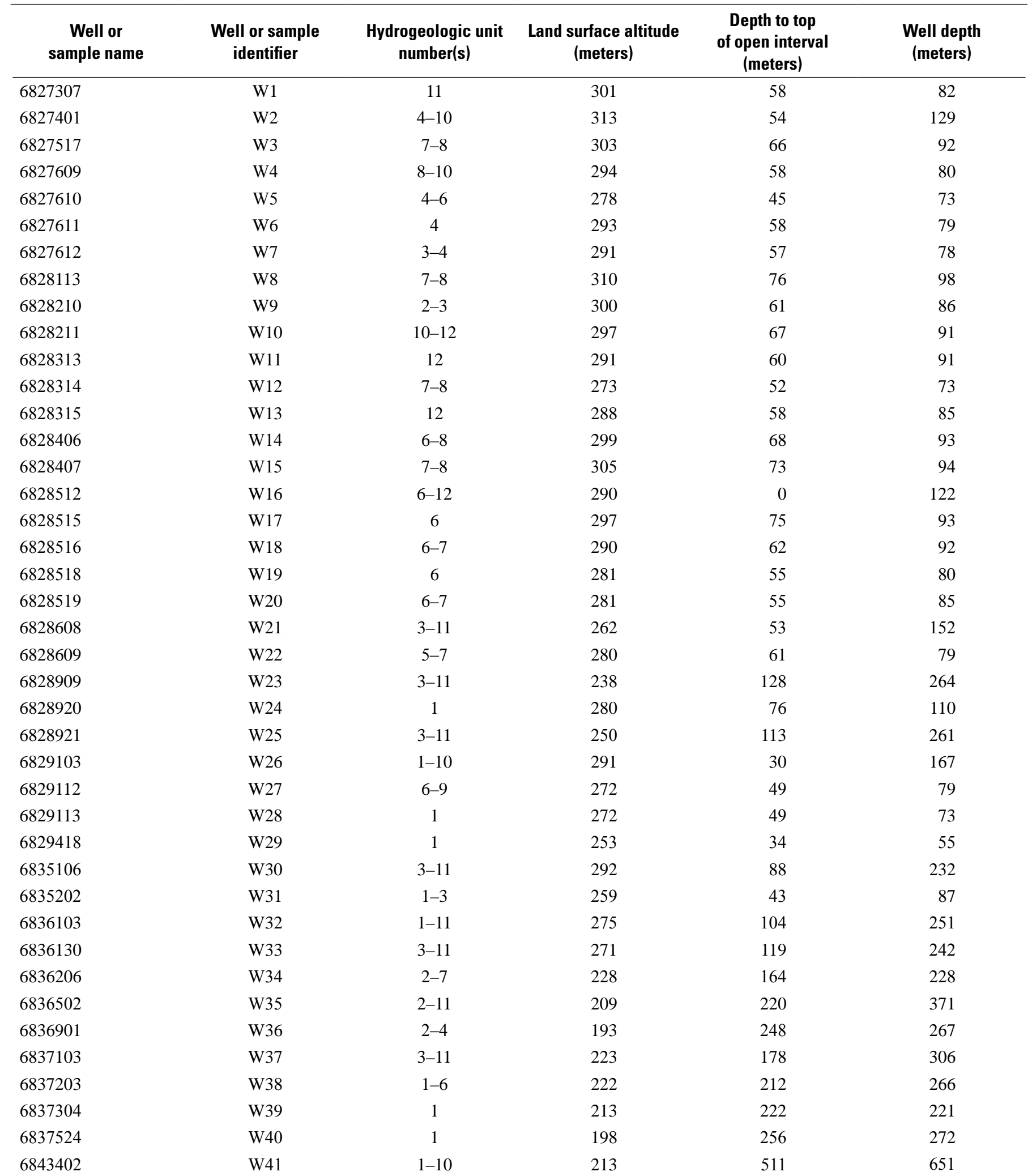


Table 1. Summary of groundwater wells used in the local-scale model, San Antonio region, Texas. - Continued

[Hydrogeologic unit numbers refer to hydrogeologic units as follows: 1 is overburden, 2 is Georgetown, 3 is cyclic and marine, 4 is leached and collapsed, 5 is upper high $\mathrm{K}$ (conduit), 6 is regional dense, 7 is grainstone, 8 is Kirschberg evaporite, 9 is lower high $\mathrm{K}$ (conduit), 10 is dolomitic, 11 is basal nodular, 12 is Glen Rose (Trinity Group); WZ4W is wellhead sample for well WZ4; WZ4S is shallow depth-dependent sampling interval for well WZ4; WZ4I is intermediate depth-dependent sampling interval for well WZ4; WZ4D is deep depth-dependent sampling interval for well WZ4; WZ5W is wellhead sample for well WZ5; WZ6W is wellhead sample for well WZ6; WZ2W is wellhead sample for well WZ2; WZ3W is wellhead sample for well WZ3]

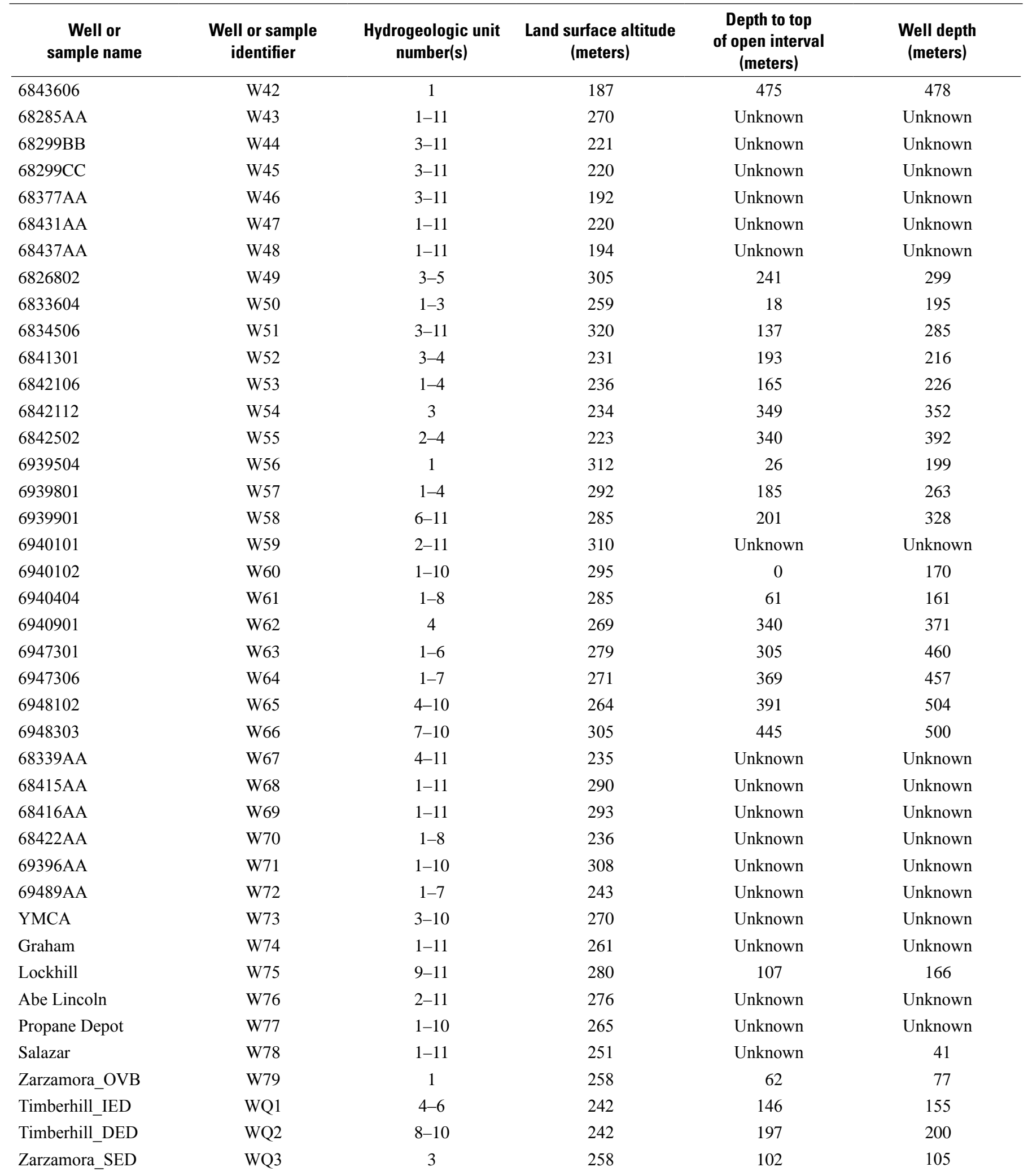


Table 1. Summary of groundwater wells used in the local-scale model, San Antonio region, Texas.-Continued

[Hydrogeologic unit numbers refer to hydrogeologic units as follows: 1 is overburden, 2 is Georgetown, 3 is cyclic and marine, 4 is leached and collapsed, 5 is upper high $\mathrm{K}$ (conduit), 6 is regional dense, 7 is grainstone, 8 is Kirschberg evaporite, 9 is lower high $\mathrm{K}$ (conduit), 10 is dolomitic, 11 is basal nodular, 12 is Glen Rose (Trinity Group); WZ4W is wellhead sample for well WZ4; WZ4S is shallow depth-dependent sampling interval for well WZ4; WZ4I is intermediate depth-dependent sampling interval for well WZ4; WZ4D is deep depth-dependent sampling interval for well WZ4; WZ5W is wellhead sample for well WZ5; WZ6W is wellhead sample for well WZ6; WZ2W is wellhead sample for well WZ2; WZ3W is wellhead sample for well WZ3]

\begin{tabular}{|c|c|c|c|c|c|}
\hline $\begin{array}{c}\text { Well or } \\
\text { sample name }\end{array}$ & $\begin{array}{l}\text { Well or sample } \\
\text { identifier }\end{array}$ & $\begin{array}{l}\text { Hydrogeologic unit } \\
\text { number(s) }\end{array}$ & $\begin{array}{l}\text { Land surface altitude } \\
\text { (meters) }\end{array}$ & $\begin{array}{l}\text { Depth to top } \\
\text { of open interval } \\
\text { (meters) }\end{array}$ & $\begin{array}{l}\text { Well depth } \\
\text { (meters) }\end{array}$ \\
\hline Zarzamora_IED & WQ4 & 4 & 258 & 121 & 127 \\
\hline Zarzamora_DED & WQ5 & $7-8$ & 258 & 179 & 182 \\
\hline WZ4W & Q1 & $2-11$ & 271 & 98 & 249 \\
\hline WZ4S & Q2 & 3 & 271 & 98 & 249 \\
\hline WZ4I & Q3 & $4-5$ & 271 & 98 & 249 \\
\hline WZ4D & Q4 & $8-9$ & 271 & 98 & 249 \\
\hline WZ5W & Q5 & $4-11$ & 275 & 123 & 240 \\
\hline WZ6W & Q6 & $4-11$ & 276 & 122 & 250 \\
\hline WZ2W & Q7 & $2-11$ & 277 & 104 & 251 \\
\hline WZ3W & Q8 & $2-11$ & 271 & 98 & 246 \\
\hline Parkwood Park & Q9 & $4-6$ & 273 & 45 & 70 \\
\hline Indian Meadows & Q10 & $6-7$ & 289 & 62 & 92 \\
\hline Lockhill-S-PO & Q11 & 1 & 297 & 75 & 93 \\
\hline DeZavala PO & Q12 & $7-8$ & 298 & 68 & 93 \\
\hline Helotes & Q13 & $6-8$ & 304 & 66 & 91 \\
\hline Bluestone & Q14 & $3-4$ & 293 & 57 & 78 \\
\hline Western Oak & Q15 & $7-10$ & 293 & 58 & 80 \\
\hline Huebner at Olmos & Q16 & 6 & 280 & 55 & 85 \\
\hline VJ Beckwith & Q17 & $7-8$ & 305 & 73 & 94 \\
\hline Roadrunner Way & Q18 & $2-4$ & 294 & 58 & 79 \\
\hline Shavano Woods & Q19 & $10-11$ & 294 & 55 & 80 \\
\hline SP-Cliffside & Q20 & 6 & 282 & 55 & 80 \\
\hline Babcock Firestation & Q21 & 10-11 & 303 & 58 & 82 \\
\hline SP-Fawn Drive & Q22 & $10-11$ & 297 & 67 & 91 \\
\hline UTSA at Regency & Q23 & $6-7$ & 309 & 76 & 98 \\
\hline Lockhill S (at 1604) & Q24 & $1-3$ & 301 & 61 & 86 \\
\hline Landrum & Q25 & $1-4$ & 290 & 55 & 98 \\
\hline O. Martin & Q26 & $4-8$ & 318 & 32 & 87 \\
\hline Wiemers & Q27 & $1-10$ & 330 & 2 & 122 \\
\hline Lehmberg & Q28 & $1-10$ & 336 & Unknown & 109 \\
\hline Walthour & Q29 & 12 & 379 & 98 & 130 \\
\hline Shavano Park (no. 6) & Q30 & $11-12$ & 293 & 83 & 148 \\
\hline 34th St Sta & Q31 & $1-11$ & 208 & 155 & 380 \\
\hline Lockhill-Selma & Q32 & $3-5$ & 258 & 161 & 195 \\
\hline Fohn Farms & Q33 & $2-7$ & 285 & 74 & 158 \\
\hline Bendele, Ken & Q34 & $5-7$ & 277 & 157 & 172 \\
\hline SanPedro Springs 4D & Q35 & $2-11$ & 201 & NA & NA \\
\hline Medina JHS & Q36 & $1-7$ & 231 & 106 & 414 \\
\hline Yancy \#3 & Q37 & $2-10$ & 320 & 355 & 450 \\
\hline
\end{tabular}


Table 2. Summary of water-level measurements obtained from monitoring and observation wells used in the local-scale model, San Antonio region, Texas.

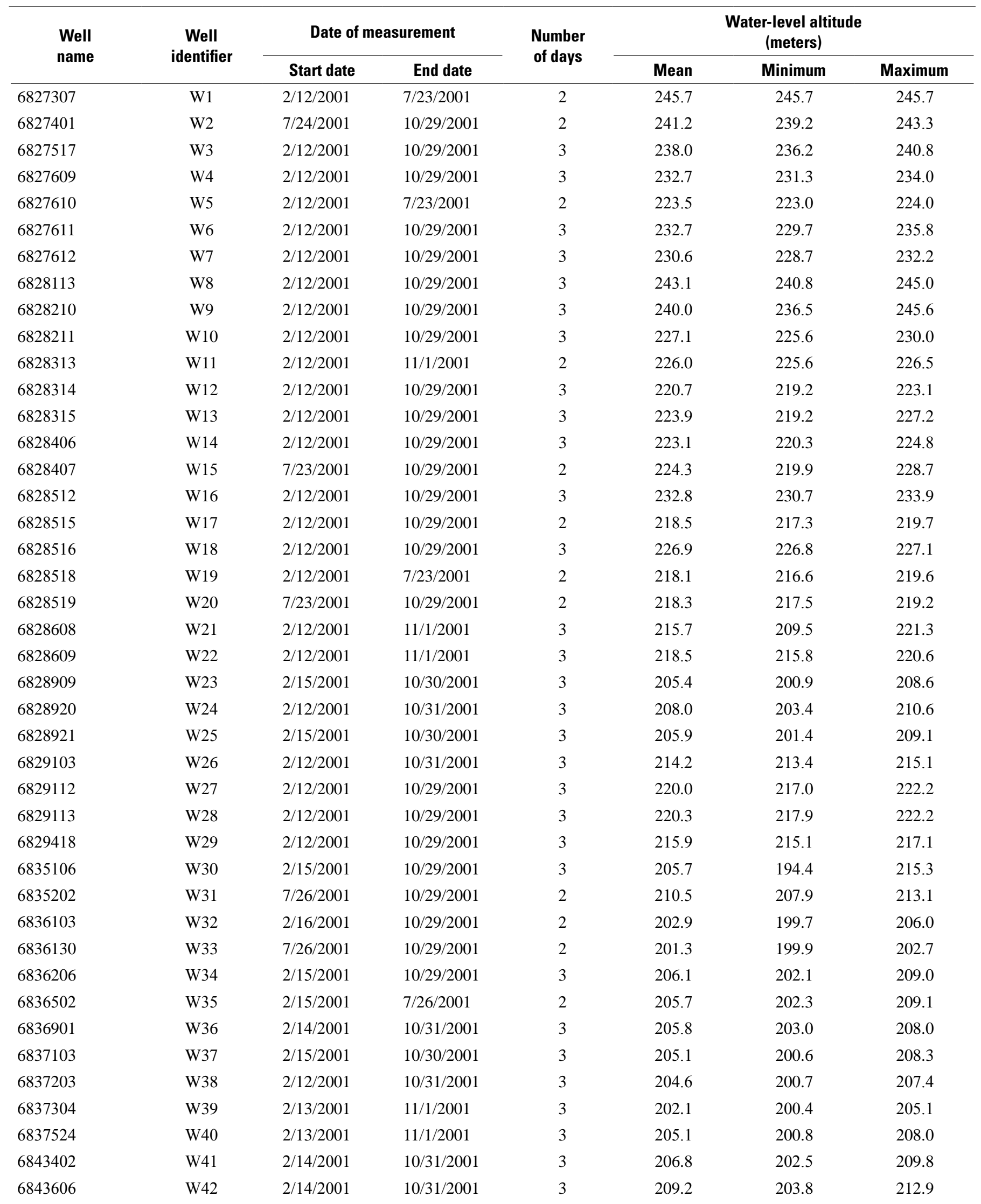


Table 2. Summary of water-level measurements obtained from monitoring and observation wells used in the local-scale model, San Antonio region, Texas.-Continued

\begin{tabular}{|c|c|c|c|c|c|c|c|}
\hline \multirow{2}{*}{$\begin{array}{l}\text { Well } \\
\text { name }\end{array}$} & \multirow{2}{*}{$\begin{array}{c}\text { Well } \\
\text { identifier }\end{array}$} & \multicolumn{2}{|c|}{ Date of measurement } & \multirow{2}{*}{$\begin{array}{l}\text { Number } \\
\text { of days }\end{array}$} & \multicolumn{3}{|c|}{$\begin{array}{l}\text { Water-level altitude } \\
\text { (meters) }\end{array}$} \\
\hline & & Start date & End date & & Mean & Minimum & Maximum \\
\hline $68285 \mathrm{AA}$ & W43 & $2 / 12 / 2001$ & $11 / 1 / 2001$ & 3 & 184.8 & 182.6 & 186.4 \\
\hline 68299BB & W44 & $2 / 12 / 2001$ & $10 / 31 / 2001$ & 3 & 203.5 & 199.8 & 206.0 \\
\hline 68299CC & W45 & $2 / 12 / 2001$ & $10 / 31 / 2001$ & 2 & 204.0 & 201.8 & 206.2 \\
\hline 68377AA & W46 & $2 / 13 / 2001$ & $11 / 1 / 2001$ & 3 & 197.1 & 193.4 & 199.9 \\
\hline 68431AA & W47 & $2 / 14 / 2001$ & $10 / 31 / 2001$ & 3 & 209.8 & 205.6 & 212.8 \\
\hline 68437AA & W48 & $2 / 14 / 2001$ & $10 / 31 / 2001$ & 3 & 203.8 & 198.9 & 208.5 \\
\hline 6826802 & W49 & $2 / 12 / 2001$ & $10 / 31 / 2001$ & 3 & 236.7 & 230.9 & 242.7 \\
\hline 6833604 & W50 & $2 / 12 / 2001$ & $10 / 30 / 2001$ & 3 & 215.6 & 211.8 & 218.5 \\
\hline 6834506 & W51 & $2 / 15 / 2001$ & $10 / 29 / 2001$ & 3 & 212.6 & 208.7 & 215.6 \\
\hline 6841301 & W52 & $2 / 12 / 2001$ & $10 / 30 / 2001$ & 3 & 213.4 & 209.8 & 216.1 \\
\hline 6842106 & W53 & $2 / 13 / 2001$ & $10 / 29 / 2001$ & 3 & 213.5 & 209.1 & 216.7 \\
\hline 6842112 & W54 & $2 / 12 / 2001$ & $10 / 29 / 2001$ & 3 & 209.9 & 208.6 & 210.6 \\
\hline 6842502 & W55 & $2 / 12 / 2001$ & $10 / 30 / 2001$ & 3 & 211.5 & 207.4 & 214.5 \\
\hline 6939504 & W56 & $2 / 14 / 2001$ & $11 / 2 / 2001$ & 3 & 262.7 & 261.8 & 263.3 \\
\hline 6939801 & W57 & $2 / 14 / 2001$ & $11 / 2 / 2001$ & 3 & 230.0 & 227.3 & 232.0 \\
\hline 6939901 & W58 & $2 / 14 / 2001$ & $11 / 2 / 2001$ & 3 & 228.1 & 225.2 & 230.3 \\
\hline 6940101 & W59 & $2 / 14 / 2001$ & $11 / 2 / 2001$ & 3 & 264.9 & 263.9 & 265.8 \\
\hline 6940102 & W60 & $2 / 14 / 2001$ & $11 / 2 / 2001$ & 3 & 253.1 & 252.2 & 254.0 \\
\hline 6940404 & W61 & $2 / 14 / 2001$ & $11 / 2 / 2001$ & 2 & 236.9 & 236.1 & 237.8 \\
\hline 6940901 & W62 & $2 / 14 / 2001$ & $10 / 30 / 2001$ & 3 & 218.3 & 214.8 & 220.9 \\
\hline 6947301 & W63 & $2 / 12 / 2001$ & $11 / 2 / 2001$ & 3 & 219.6 & 215.6 & 223.3 \\
\hline 6947306 & W64 & $2 / 12 / 2001$ & $10 / 31 / 2001$ & 3 & 218.9 & 215.4 & 221.5 \\
\hline 6948102 & W65 & $2 / 12 / 2001$ & $11 / 1 / 2001$ & 3 & 218.7 & 215.2 & 221.1 \\
\hline 6948303 & W66 & $2 / 13 / 2001$ & $11 / 2 / 2001$ & 3 & 213.9 & 210.3 & 217.9 \\
\hline 68339AA & W67 & $2 / 12 / 2001$ & 10/30/2001 & 3 & 214.6 & 210.8 & 217.2 \\
\hline $68415 \mathrm{AA}$ & W68 & 2/13/2001 & 10/29/2001 & 3 & 214.3 & 210.3 & 217.2 \\
\hline 68416AA & W69 & $2 / 14 / 2001$ & $10 / 29 / 2001$ & 3 & 213.0 & 208.9 & 216.0 \\
\hline $68422 \mathrm{AA}$ & W70 & 2/12/2001 & $10 / 30 / 2001$ & 3 & 211.5 & 207.4 & 214.4 \\
\hline 69396AA & W71 & $2 / 14 / 2001$ & $11 / 2 / 2001$ & 3 & 241.9 & 241.2 & 243.0 \\
\hline 69489AA & W72 & 2/13/2001 & $11 / 2 / 2001$ & 3 & 223.5 & 220.4 & 226.0 \\
\hline YMCA & W73 & $5 / 10 / 2007$ & 1/31/2010 & 662 & 218.5 & 206.7 & 238.8 \\
\hline Graham & W74 & $6 / 14 / 2007$ & 2/9/2010 & 873 & 217.8 & 204.9 & 235.8 \\
\hline Lockhill & W75 & $5 / 4 / 2007$ & 2/9/2010 & 937 & 228.8 & 217.5 & 239.2 \\
\hline Abe Lincoln & W76 & 6/20/2007 & $5 / 12 / 2009$ & 673 & 214.8 & 203.7 & 226.3 \\
\hline Propane Depot & W77 & $5 / 14 / 2007$ & $1 / 15 / 2010$ & 887 & 209.6 & 197.6 & 224.1 \\
\hline Salazar & W78 & $5 / 15 / 2007$ & 6/8/2007 & 25 & 213.2 & 212.2 & 214.1 \\
\hline Zarzamora_OVB & W79 & $10 / 17 / 2008$ & $2 / 9 / 2010$ & 762 & 212.7 & 209.3 & 219.6 \\
\hline Timberhill_IED & WQ1 & $10 / 17 / 2008$ & 2/3/2010 & 462 & 204.7 & 198.0 & 211.1 \\
\hline Timberhill_DED & WQ2 & $10 / 17 / 2008$ & $2 / 3 / 2010$ & 462 & 204.9 & 198.2 & 210.0 \\
\hline Zarzamora_SED & WQ3 & $10 / 17 / 2008$ & 2/9/2010 & 619 & 206.3 & 197.5 & 215.0 \\
\hline Zarzamora_IED & WQ4 & $10 / 17 / 2008$ & 2/9/2010 & 552 & 207.6 & 198.2 & 215.5 \\
\hline Zarzamora_DED & WQ5 & 9/12/2007 & $11 / 30 / 2009$ & 627 & 207.8 & 197.7 & 219.6 \\
\hline
\end{tabular}


Table 3. Hydraulic properties for the Edwards aquifer, San Antonio region, Texas.

$\left[\mathrm{m}^{-1}\right.$, per meter; $\mathrm{m} / \mathrm{d}$, meters per day; $\mathrm{m}^{2} / \mathrm{d}$, meters squared per day; NA, no reported value]

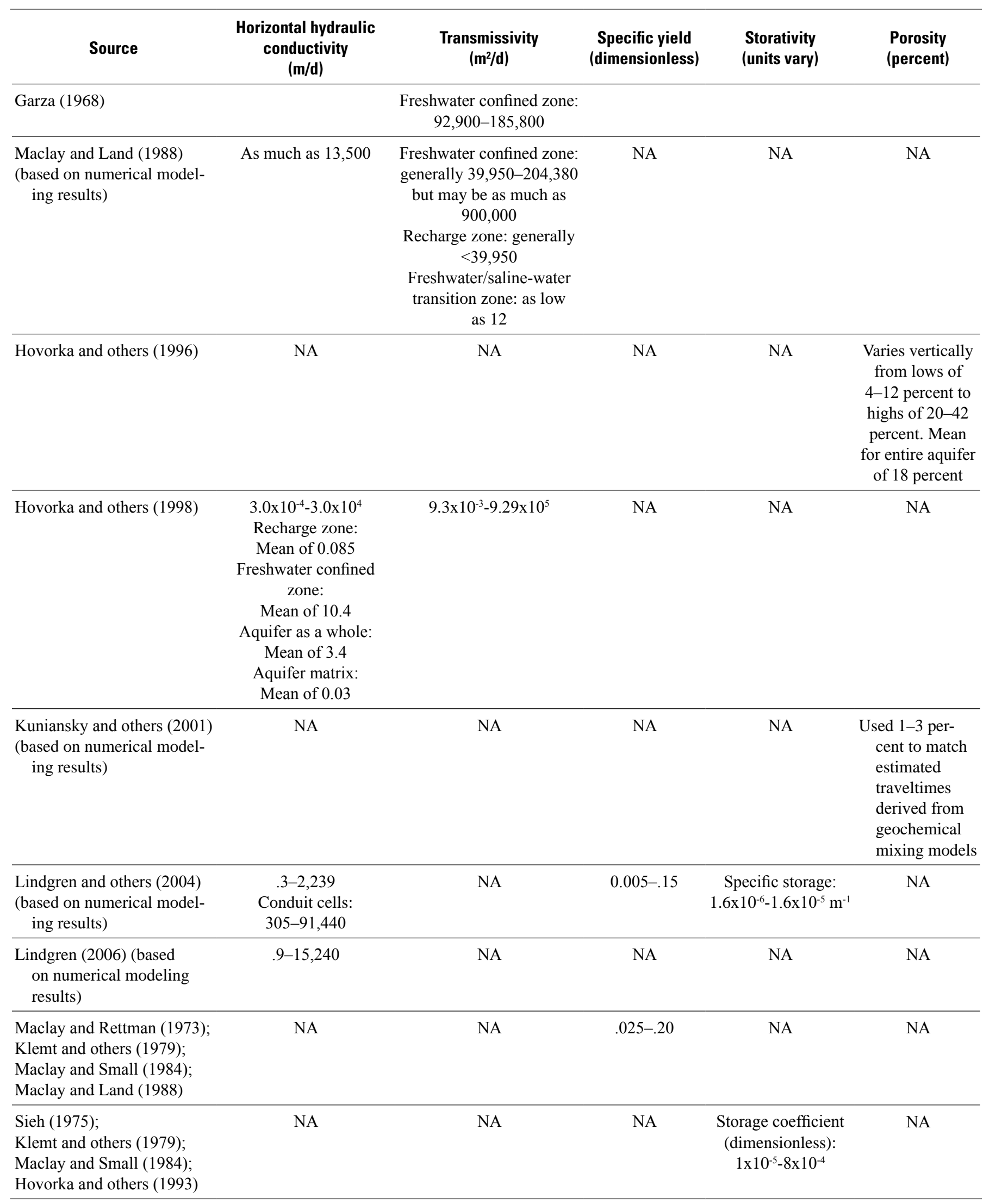


Table 4. Estimated recharge rates, by recharge subzone, in the local-scale model area during 2001, San Antonio region, Texas.

[Monthly recharge rates have been estimated by the U.S. Geological Survey for the San Antonio segment of the Edwards aquifer since 1934. Streambed recharge is 85 percent of the total recharge. Diffuse

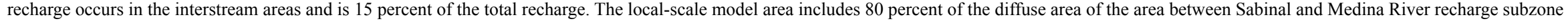
and 69 percent of the diffuse area of the area between Medina River and Cibolo-Dry Comal Creek recharge subzone. The local-scale model includes the whole area (100 percent) of the diffuse area of the Medina River recharge subzone. Annual totals are in cubic meters per year]

\begin{tabular}{|c|c|c|c|c|c|c|c|c|c|c|c|c|c|}
\hline \multirow{4}{*}{ Month-Year } & \multicolumn{13}{|c|}{$\begin{array}{l}\text { Estimated recharge rate } \\
\text { (cubic meters per month) }\end{array}$} \\
\hline & \multicolumn{13}{|c|}{ Recharge subzone } \\
\hline & \multicolumn{5}{|c|}{ Area between Sabinal and Medina River } & \multicolumn{3}{|c|}{ Medina River } & \multicolumn{5}{|c|}{ Area between Medina River and Cibolo-Dry Comal Creek } \\
\hline & Streambed & $\begin{array}{l}\text { Subzone } \\
\text { diffuse }\end{array}$ & $\begin{array}{l}\text { Subzone } \\
\text { total }\end{array}$ & $\begin{array}{l}\text { Local- } \\
\text { scale } \\
\text { model } \\
\text { area } \\
\text { diffuse }\end{array}$ & $\begin{array}{l}\text { Local- } \\
\text { scale } \\
\text { model } \\
\text { area } \\
\text { total }\end{array}$ & Streambed & $\begin{array}{l}\text { Subzone } \\
\text { diffuse }\end{array}$ & $\begin{array}{l}\text { Subzone } \\
\text { total }\end{array}$ & Streambed & $\begin{array}{l}\text { Subzone } \\
\text { diffuse }\end{array}$ & $\begin{array}{l}\text { Subzone } \\
\text { total }\end{array}$ & $\begin{array}{l}\text { Local- } \\
\text { scale } \\
\text { model } \\
\text { area } \\
\text { diffuse }\end{array}$ & $\begin{array}{l}\text { Local- } \\
\text { scale } \\
\text { model } \\
\text { area } \\
\text { total }\end{array}$ \\
\hline January-01 & $18,742,214$ & $3,307,450$ & $22,049,663$ & $2,645,960$ & $21,388,173$ & $6,186,729$ & $1,091,776$ & $7,278,505$ & $10,473,645$ & $1,848,162$ & $12,321,807$ & $1,275,232$ & $11,748,877$ \\
\hline February-01 & $12,457,528$ & $2,198,387$ & $14,655,916$ & $1,758,710$ & $14,216,238$ & $6,711,028$ & $1,184,299$ & $7,895,327$ & $13,722,768$ & $2,421,665$ & $16,144,433$ & $1,670,949$ & $15,393,717$ \\
\hline March-01 & $22,436,299$ & $3,959,511$ & $26,395,810$ & $3,167,609$ & $25,603,908$ & $7,445,047$ & $1,313,832$ & $8,758,879$ & $16,261,907$ & $2,869,615$ & $19,131,522$ & $1,980,035$ & $18,241,941$ \\
\hline April-01 & $9,702,746$ & $1,712,249$ & $11,414,995$ & $1,369,799$ & $11,072,545$ & $9,122,804$ & $1,609,907$ & $10,732,710$ & $10,338,079$ & $1,824,367$ & $12,162,446$ & $1,258,813$ & $11,596,892$ \\
\hline May-01 & $22,833,533$ & $4,029,318$ & $26,862,851$ & $3,223,455$ & $26,056,987$ & $9,619,839$ & $1,697,619$ & $11,317,458$ & $8,581,385$ & $1,514,362$ & $10,095,747$ & $1,044,910$ & $9,626,295$ \\
\hline June-01 & $5,297,442$ & 934,843 & $6,232,285$ & 747,874 & $6,045,316$ & $7,549,907$ & $1,332,336$ & $8,882,243$ & $1,756,147$ & 309,908 & $2,066,055$ & 213,837 & $1,969,983$ \\
\hline July-01 & $2,985,484$ & 526,850 & $3,512,334$ & 421,480 & $3,406,964$ & $6,870,415$ & $1,212,426$ & $8,082,841$ & $1,468,692$ & 259,181 & $1,727,872$ & 178,835 & $1,647,526$ \\
\hline August-01 & $4,518,841$ & 797,605 & $5,316,446$ & 638,084 & $5,156,925$ & $6,085,015$ & $1,073,826$ & $7,158,841$ & 0 & 0 & 0 & 0 & 0 \\
\hline September-01 & $7,134,168$ & $1,258,835$ & $8,393,003$ & $1,007,068$ & $8,141,236$ & $8,650,318$ & $1,526,636$ & $10,176,953$ & $7,934,647$ & $1,400,232$ & $9,334,879$ & 966,160 & $8,900,807$ \\
\hline October-01 & $2,987,888$ & 527,406 & $3,515,294$ & 421,925 & $3,409,813$ & $6,711,028$ & $1,184,299$ & $7,895,327$ & $8,638,277$ & $1,524,402$ & $10,162,679$ & $1,051,837$ & $9,690,115$ \\
\hline November-01 & $17,877,007$ & $3,154,766$ & $21,031,773$ & $2,523,813$ & $20,400,819$ & $9,489,196$ & $1,674,673$ & $11,163,869$ & $13,654,743$ & $2,409,661$ & $16,064,404$ & $1,662,666$ & $15,317,409$ \\
\hline December-01 & $3,193,273$ & 563,519 & $3,756,792$ & 450,815 & $3,644,089$ & $9,880,940$ & $1,743,695$ & $11,624,636$ & $13,625,467$ & $2,404,494$ & $16,029,961$ & $1,659,101$ & $15,284,568$ \\
\hline Annual & $130,166,424$ & $22,970,739$ & $153,137,163$ & $18,376,591$ & $148,543,015$ & $94,322,265$ & $16,645,323$ & $110,967,589$ & $106,455,757$ & $18,786,049$ & $125,241,806$ & $12,962,374$ & $119,418,131$ \\
\hline
\end{tabular}


Table 5. Mean daily and mean annual groundwater-withdrawal rates from municipal, industrial, irrigation, and livestock wells in the local-scale study area during 2001, San Antonio region, Texas.

[Locations of wells are shown in figure 14; MUN, municipal well; IND, industrial well; IRR, irrigation well; STK, livestock well. Withdrawal rates provided by San Antonio Water System (2008), Bexar Metropolitan Water District, and Edwards Aquifer Authority (2009)]

\begin{tabular}{|c|c|c|c|c|c|}
\hline $\begin{array}{c}\text { Well } \\
\text { number }\end{array}$ & $\begin{array}{l}\text { Water use } \\
\text { type }\end{array}$ & $\begin{array}{l}\text { Altitude of top of } \\
\text { open interval } \\
\text { (meters) }\end{array}$ & $\begin{array}{c}\text { Altitude of bottom } \\
\text { of open interval } \\
\text { (meters) }\end{array}$ & $\begin{array}{c}\text { Withdrawal rate } \\
\text { (cubic meters per day) }\end{array}$ & $\begin{array}{c}\text { Withdrawal rate } \\
\text { (cubic meters per year) }\end{array}$ \\
\hline BE00269-005 & MUN & 178 & 54 & 17,386 & $6,346,037$ \\
\hline BE00269-006 & MUN & 170 & 52 & 17,386 & $6,346,037$ \\
\hline BE00269-007 & MUN & 164 & 50 & 17,386 & $6,346,037$ \\
\hline BE00269-008 & MUN & 162 & 49 & 17,386 & $6,346,037$ \\
\hline BE00269-095 & MUN & 170 & 52 & 15,182 & $5,541,480$ \\
\hline BE00269-096 & MUN & 178 & 54 & 15,182 & $5,541,480$ \\
\hline BE00269-097 & MUN & 173 & 53 & 15,182 & $5,541,480$ \\
\hline BE00269-098 & MUN & 171 & 52 & 15,182 & $5,541,480$ \\
\hline BE00269-080 & MUN & 119 & 36 & 12,932 & $4,720,132$ \\
\hline BE00269-045 & MUN & 106 & 32 & 10,261 & $3,745,371$ \\
\hline BE00269-046 & MUN & 110 & 34 & 10,261 & $3,745,371$ \\
\hline BE00269-047 & MUN & 107 & 33 & 10,261 & $3,745,371$ \\
\hline BE00269-048 & MUN & 99 & 30 & 10,261 & $3,745,371$ \\
\hline BE00269-101 & MUN & 106 & 32 & 10,261 & $3,745,371$ \\
\hline BE00269-903 & MUN & 96 & 29 & 10,261 & $3,745,371$ \\
\hline BE00269-902 & MUN & 116 & 35 & 8,894 & $3,246,135$ \\
\hline BE00269-032 & MUN & 29 & 9 & 8,864 & $3,235,251$ \\
\hline BE00269-054 & MUN & -43 & -13 & 6,785 & $2,476,485$ \\
\hline BE00269-055 & MUN & -45 & -14 & 6,785 & $2,476,485$ \\
\hline BE00269-056 & MUN & -43 & -13 & 6,785 & $2,476,485$ \\
\hline BE00269-057 & MUN & -46 & -14 & 6,785 & $2,476,485$ \\
\hline BE00269-027 & MUN & -96 & -29 & 6,668 & $2,433,921$ \\
\hline BE00269-028 & MUN & -3 & -1 & 6,668 & $2,433,921$ \\
\hline BE00227-024 & MUN & 133 & 41 & 6,093 & $2,224,056$ \\
\hline BE00058-003 & MUN & 65 & 20 & 5,419 & $1,977,830$ \\
\hline BE00239-001 & MUN & -130 & -40 & 5,243 & $1,913,827$ \\
\hline BE00269-089 & MUN & 94 & 29 & 5,227 & $1,907,799$ \\
\hline BE00227-017 & MUN & 96 & 29 & 5,154 & $1,881,388$ \\
\hline BE00269-020 & MUN & 48 & 15 & 5,084 & $1,855,712$ \\
\hline BE00269-021 & MUN & 42 & 13 & 5,084 & $1,855,712$ \\
\hline
\end{tabular}




\section{Simulations of Groundwater Flow and Particle-Tracking Analysis in the Zone of Contribution to a Public-Supply Well}

Table 5. Mean daily and mean annual groundwater-withdrawal rates from municipal, industrial, irrigation, and livestock wells in the local-scale study area during 2001, San Antonio region, Texas.-Continued

[Locations of wells are shown in figure 14; MUN, municipal well; IND, industrial well; IRR, irrigation well; STK, livestock well. Withdrawal rates provided by San Antonio Water System (2008), Bexar Metropolitan Water District, and Edwards Aquifer Authority (2009)]

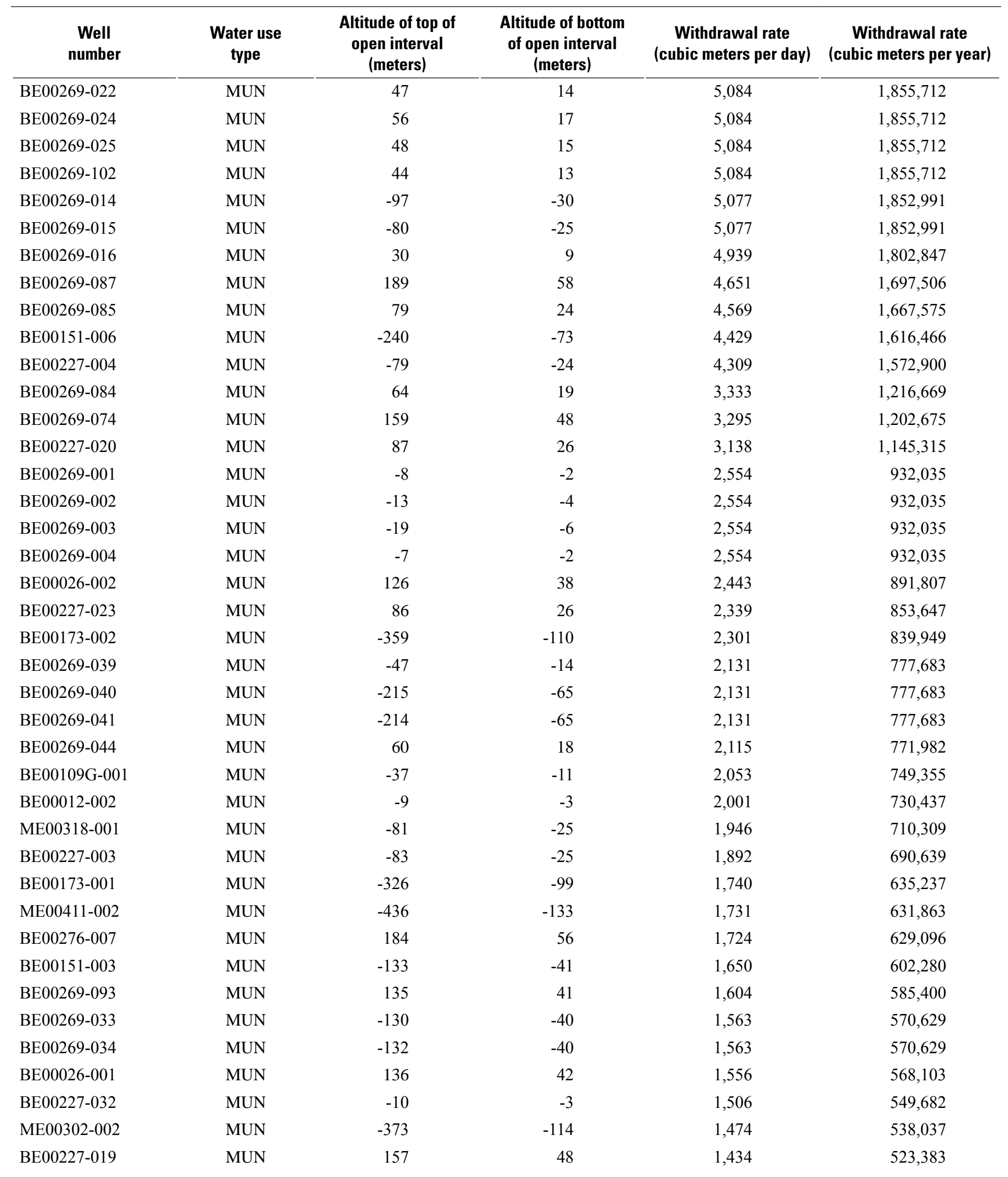


Table 5. Mean daily and mean annual groundwater-withdrawal rates from municipal, industrial, irrigation, and livestock wells in the local-scale study area during 2001, San Antonio region, Texas.-Continued

[Locations of wells are shown in figure 14; MUN, municipal well; IND, industrial well; IRR, irrigation well; STK, livestock well. Withdrawal rates provided by San Antonio Water System (2008), Bexar Metropolitan Water District, and Edwards Aquifer Authority (2009)]

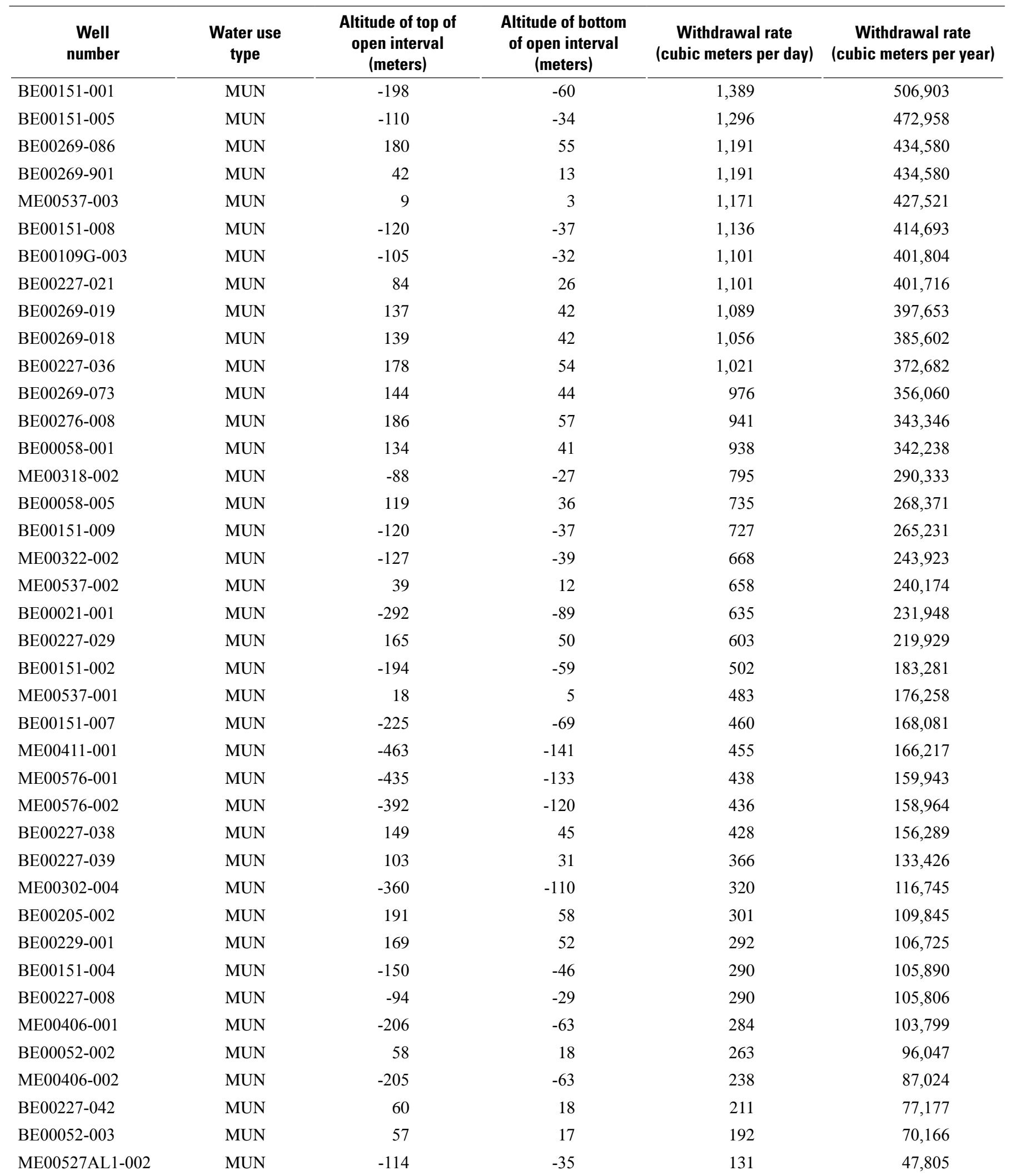


Table 5. Mean daily and mean annual groundwater-withdrawal rates from municipal, industrial, irrigation, and livestock wells in the local-scale study area during 2001, San Antonio region, Texas.-Continued

[Locations of wells are shown in figure 14; MUN, municipal well; IND, industrial well; IRR, irrigation well; STK, livestock well. Withdrawal rates provided by San Antonio Water System (2008), Bexar Metropolitan Water District, and Edwards Aquifer Authority (2009)]

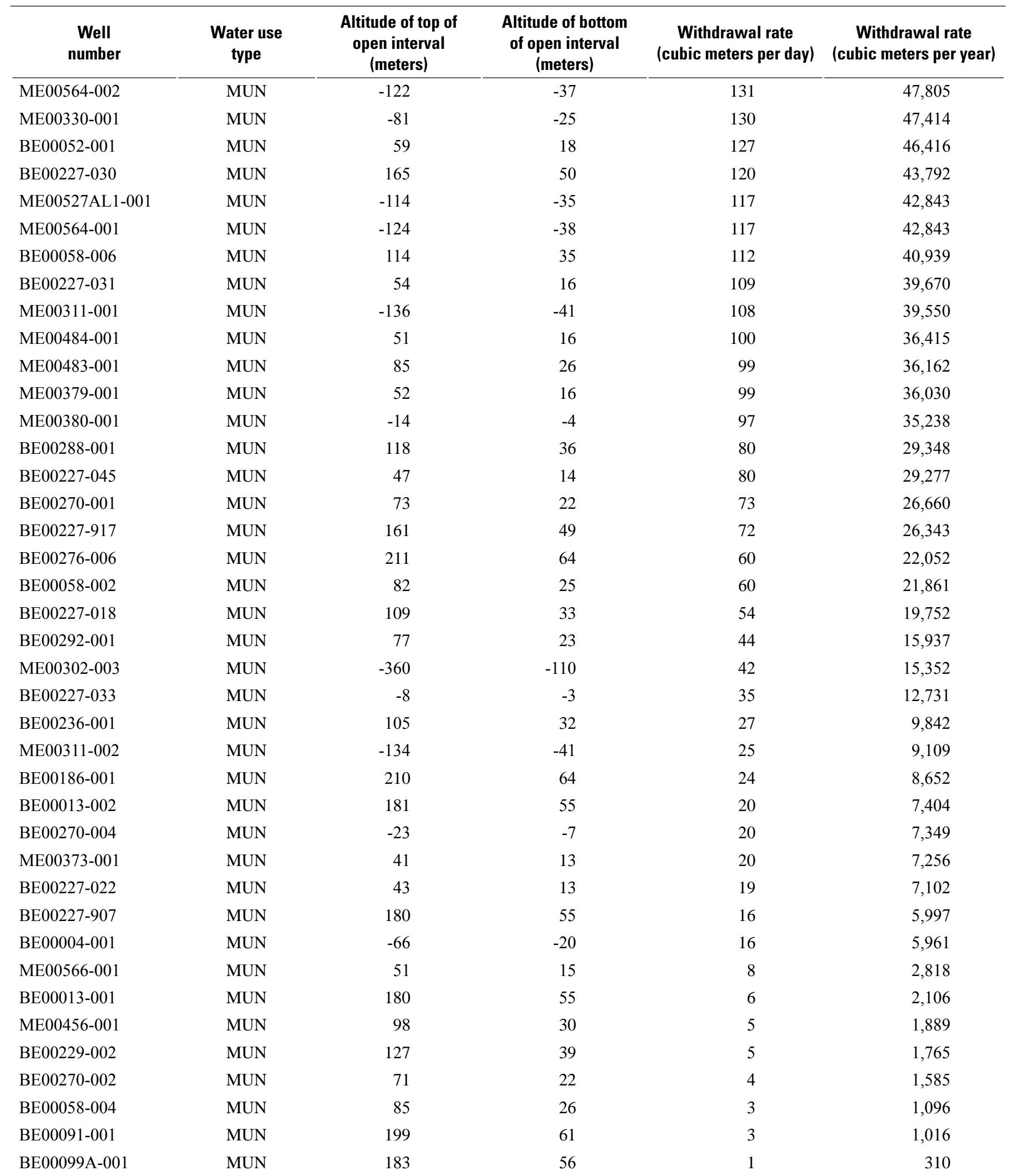


Table 5. Mean daily and mean annual groundwater-withdrawal rates from municipal, industrial, irrigation, and livestock wells in the local-scale study area during 2001, San Antonio region, Texas.-Continued

[Locations of wells are shown in figure 14; MUN, municipal well; IND, industrial well; IRR, irrigation well; STK, livestock well. Withdrawal rates provided by San Antonio Water System (2008), Bexar Metropolitan Water District, and Edwards Aquifer Authority (2009)]

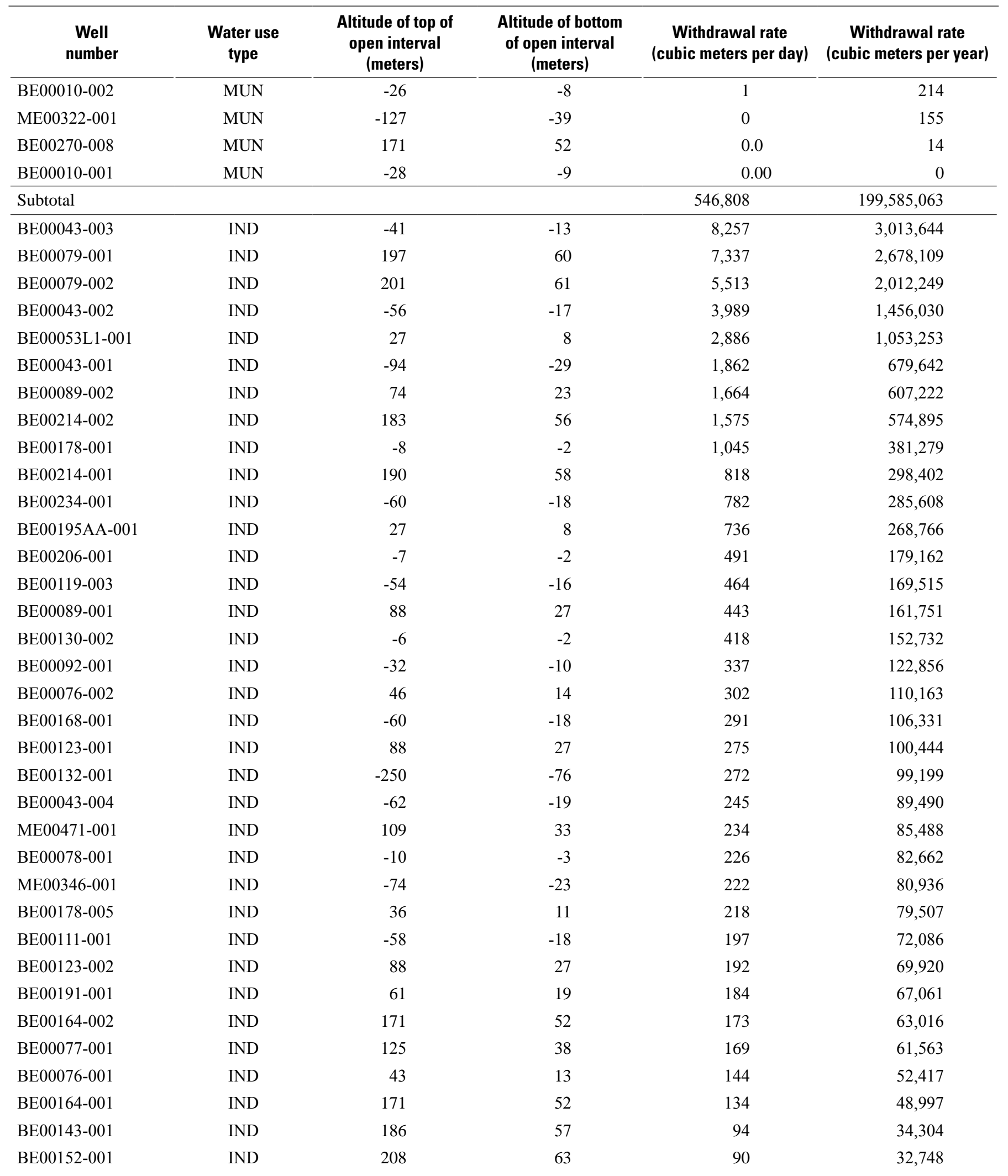


Table 5. Mean daily and mean annual groundwater-withdrawal rates from municipal, industrial, irrigation, and livestock wells in the local-scale study area during 2001, San Antonio region, Texas.-Continued

[Locations of wells are shown in figure 14; MUN, municipal well; IND, industrial well; IRR, irrigation well; STK, livestock well. Withdrawal rates provided by San Antonio Water System (2008), Bexar Metropolitan Water District, and Edwards Aquifer Authority (2009)]

\begin{tabular}{|c|c|c|c|c|c|}
\hline $\begin{array}{c}\text { Well } \\
\text { number }\end{array}$ & $\begin{array}{l}\text { Water use } \\
\text { type }\end{array}$ & $\begin{array}{c}\text { Altitude of top of } \\
\text { open interval } \\
\text { (meters) }\end{array}$ & $\begin{array}{l}\text { Altitude of bottom } \\
\text { of open interval } \\
\text { (meters) }\end{array}$ & $\begin{array}{c}\text { Withdrawal rate } \\
\text { (cubic meters per day) }\end{array}$ & $\begin{array}{c}\text { Withdrawal rate } \\
\text { (cubic meters per year) }\end{array}$ \\
\hline BE00089-003 & IND & 91 & 28 & 87 & 31,602 \\
\hline ME00597-001 & IND & -46 & -14 & 70 & 25,641 \\
\hline BE00038-001 & IND & -53 & -16 & 69 & 25,027 \\
\hline BE00266-001 & IND & 156 & 47 & 66 & 24,072 \\
\hline BE00119-001 & IND & -54 & -16 & 58 & 21,275 \\
\hline ME00493AA-001 & IND & 190 & 58 & 56 & 20,261 \\
\hline BE00174-001 & IND & -273 & -83 & 54 & 19,825 \\
\hline BE00208-002 & IND & 4 & 1 & 49 & 17,801 \\
\hline BE00199-001 & IND & 212 & 65 & 37 & 13,400 \\
\hline BE00095-001 & IND & 36 & 11 & 34 & 12,551 \\
\hline BE00017-002 & IND & 205 & 62 & 33 & 12,064 \\
\hline BE00017-001 & IND & 205 & 62 & 25 & 8,994 \\
\hline BE00141-001 & IND & 15 & 5 & 19 & 6,808 \\
\hline BE00070-001 & IND & -12 & -4 & 9 & 3,396 \\
\hline BE00238-001 & IND & -25 & -8 & 4 & 1,429 \\
\hline BE00111-002 & IND & -55 & -17 & 4 & 1,382 \\
\hline BE00220-001 & IND & 79 & 24 & 4 & 1,338 \\
\hline Subtotal & & & & 43,158 & $15,752,608$ \\
\hline BE00314-001 & IRR & -269 & -82 & 3,592 & $1,311,100$ \\
\hline ME00320-001 & IRR & -141 & -43 & 3,378 & $1,233,089$ \\
\hline BE00113-001 & IRR & -326 & -99 & 3,340 & $1,218,955$ \\
\hline ME00343-001 & IRR & 185 & 56 & 2,818 & $1,028,532$ \\
\hline ME00358-001 & IRR & 74 & 22 & 2,745 & $1,001,813$ \\
\hline ME00349-003 & IRR & 235 & 72 & 2,739 & 999,575 \\
\hline ME00391-001 & IRR & 153 & 47 & 2,668 & 973,773 \\
\hline ME00515-001 & IRR & -40 & -12 & 2,432 & 887,810 \\
\hline ME00325-001 & IRR & -65 & -20 & 2,413 & 880,656 \\
\hline ME00325-002 & IRR & -75 & -23 & 1,963 & 716,672 \\
\hline BE00056-001 & IRR & -286 & -87 & 1,953 & 712,941 \\
\hline ME00415-001 & IRR & -124 & -38 & 1,946 & 710,457 \\
\hline
\end{tabular}


Table 5. Mean daily and mean annual groundwater-withdrawal rates from municipal, industrial, irrigation, and livestock wells in the local-scale study area during 2001, San Antonio region, Texas.-Continued

[Locations of wells are shown in figure 14; MUN, municipal well; IND, industrial well; IRR, irrigation well; STK, livestock well. Withdrawal rates provided by San Antonio Water System (2008), Bexar Metropolitan Water District, and Edwards Aquifer Authority (2009)]

\begin{tabular}{|c|c|c|c|c|c|}
\hline $\begin{array}{c}\text { Well } \\
\text { number }\end{array}$ & $\begin{array}{l}\text { Water use } \\
\text { type }\end{array}$ & $\begin{array}{c}\text { Altitude of top of } \\
\text { open interval } \\
\text { (meters) }\end{array}$ & $\begin{array}{l}\text { Altitude of bottom } \\
\text { of open interval } \\
\text { (meters) }\end{array}$ & $\begin{array}{c}\text { Withdrawal rate } \\
\text { (cubic meters per day) }\end{array}$ & $\begin{array}{c}\text { Withdrawal rate } \\
\text { (cubic meters per year) }\end{array}$ \\
\hline ME00414-001 & IRR & 36 & 11 & 1,878 & 685,615 \\
\hline BE00128-001 & IRR & 182 & 55 & 1,837 & 670,603 \\
\hline ME00323-001 & IRR & -57 & -17 & 1,819 & 664,028 \\
\hline ME00507-001 & IRR & -116 & -35 & 1,654 & 603,640 \\
\hline ME00342-001 & IRR & 47 & 14 & 1,613 & 588,874 \\
\hline BE00224-001 & IRR & -318 & -97 & 1,566 & 571,577 \\
\hline ME00402-001 & IRR & -39 & -12 & 1,450 & 529,116 \\
\hline ME00352-001 & IRR & 2 & 1 & 1,448 & 528,396 \\
\hline ME00409-001 & IRR & 74 & 23 & 1,354 & 494,339 \\
\hline ME00408-001 & IRR & 78 & 24 & 1,327 & 484,402 \\
\hline ME00353-001 & IRR & -112 & -34 & 1,324 & 483,175 \\
\hline ME00521-001 & IRR & 78 & 24 & 1,279 & 467,013 \\
\hline BE00150-002 & IRR & 30 & 9 & 1,243 & 453,723 \\
\hline ME00467-001 & IRR & 61 & 19 & 1,242 & 453,351 \\
\hline BE00225-001 & IRR & -46 & -14 & 1,218 & 444,656 \\
\hline ME00599-001 & IRR & 26 & 8 & 1,176 & 429,101 \\
\hline BE00209-001 & IRR & -329 & -100 & 1,147 & 418,573 \\
\hline ME00347-001 & IRR & 5 & 2 & 998 & 364,410 \\
\hline ME00348-001 & IRR & 27 & 8 & 969 & 353,837 \\
\hline ME00344-001 & IRR & 24 & 7 & 953 & 347,776 \\
\hline BE00041-001 & IRR & -275 & -84 & 942 & 343,851 \\
\hline ME00301-001 & IRR & 91 & 28 & 940 & 343,145 \\
\hline ME00538-001 & IRR & 129 & 39 & 930 & 339,578 \\
\hline ME00368-001 & IRR & 91 & 28 & 919 & 335,355 \\
\hline BE00009-001 & IRR & -63 & -19 & 912 & 332,992 \\
\hline BE00134-001 & IRR & 69 & 21 & 887 & 323,906 \\
\hline ME00526-001 & IRR & 90 & 27 & 883 & 322,224 \\
\hline ME00535-001 & IRR & 41 & 12 & 866 & 315,979 \\
\hline AT00903-001 & IRR & -386 & -118 & 860 & 313,749 \\
\hline ME00602-001 & IRR & 36 & 11 & 845 & 308,283 \\
\hline
\end{tabular}


Table 5. Mean daily and mean annual groundwater-withdrawal rates from municipal, industrial, irrigation, and livestock wells in the local-scale study area during 2001, San Antonio region, Texas.-Continued

[Locations of wells are shown in figure 14; MUN, municipal well; IND, industrial well; IRR, irrigation well; STK, livestock well. Withdrawal rates provided by San Antonio Water System (2008), Bexar Metropolitan Water District, and Edwards Aquifer Authority (2009)]

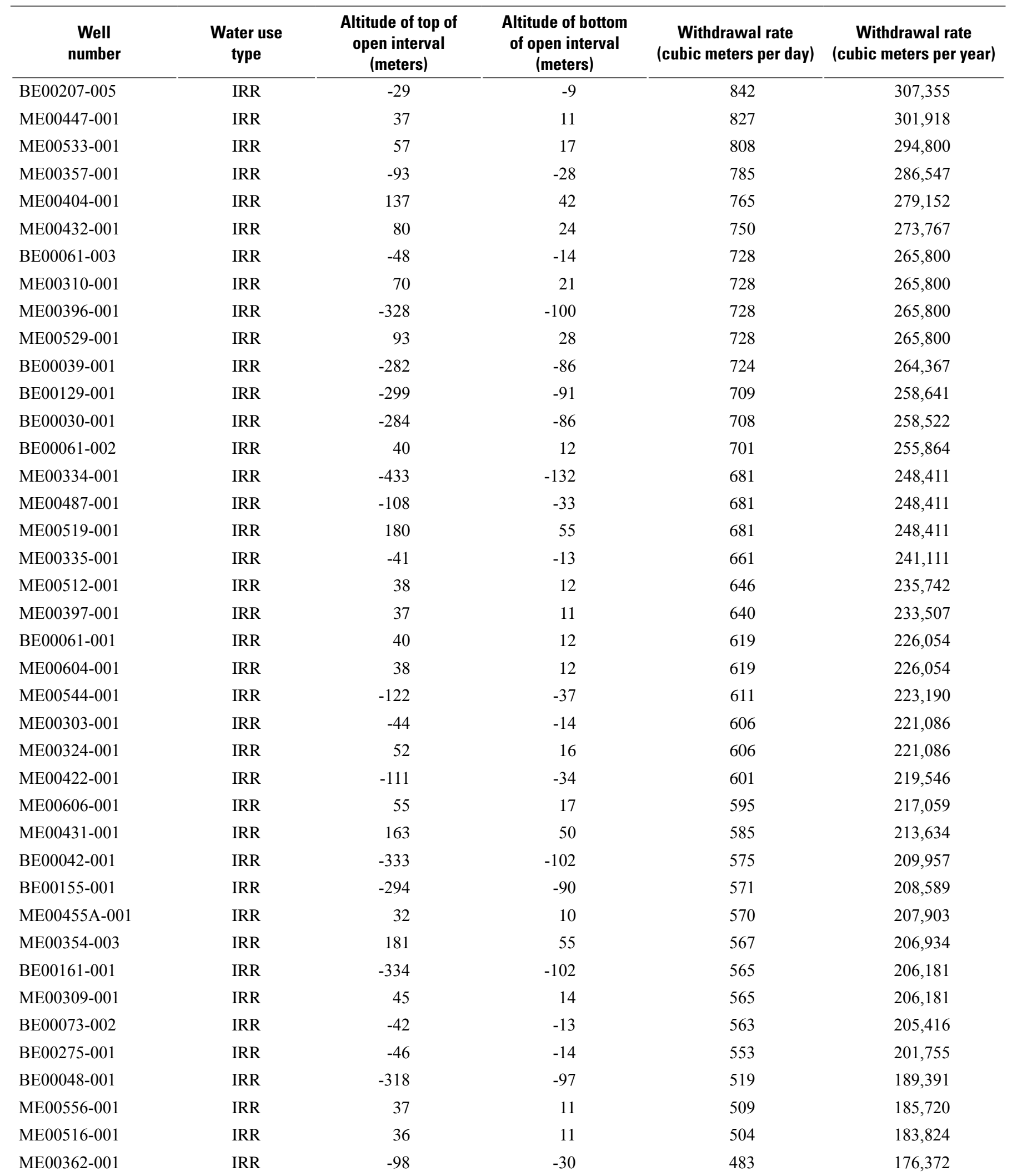


Table 5. Mean daily and mean annual groundwater-withdrawal rates from municipal, industrial, irrigation, and livestock wells in the local-scale study area during 2001, San Antonio region, Texas.-Continued

[Locations of wells are shown in figure 14; MUN, municipal well; IND, industrial well; IRR, irrigation well; STK, livestock well. Withdrawal rates provided by San Antonio Water System (2008), Bexar Metropolitan Water District, and Edwards Aquifer Authority (2009)]

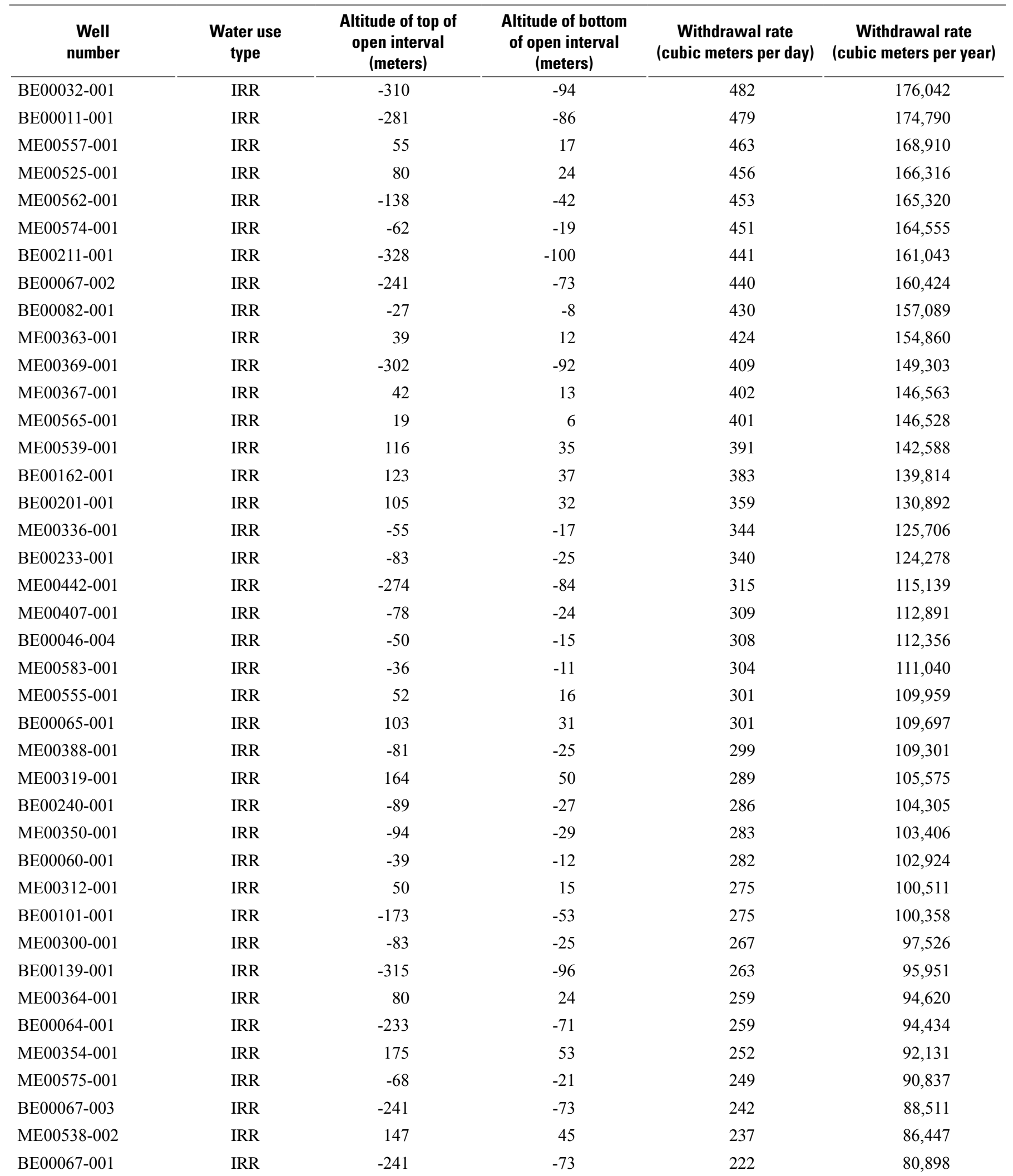


Table 5. Mean daily and mean annual groundwater-withdrawal rates from municipal, industrial, irrigation, and livestock wells in the local-scale study area during 2001, San Antonio region, Texas.-Continued

[Locations of wells are shown in figure 14; MUN, municipal well; IND, industrial well; IRR, irrigation well; STK, livestock well. Withdrawal rates provided by San Antonio Water System (2008), Bexar Metropolitan Water District, and Edwards Aquifer Authority (2009)]

\begin{tabular}{|c|c|c|c|c|c|}
\hline $\begin{array}{c}\text { Well } \\
\text { number }\end{array}$ & $\begin{array}{l}\text { Water use } \\
\text { type }\end{array}$ & $\begin{array}{c}\text { Altitude of top of } \\
\text { open interval } \\
\text { (meters) }\end{array}$ & $\begin{array}{c}\text { Altitude of bottom } \\
\text { of open interval } \\
\text { (meters) }\end{array}$ & $\begin{array}{c}\text { Withdrawal rate } \\
\text { (cubic meters per day) }\end{array}$ & $\begin{array}{c}\text { Withdrawal rate } \\
\text { (cubic meters per year) }\end{array}$ \\
\hline ME00389-001 & IRR & 66 & 20 & 213 & 77,629 \\
\hline BE00197-001 & IRR & 33 & 10 & 202 & 73,810 \\
\hline ME00476-001 & IRR & -503 & -153 & 191 & 69,555 \\
\hline BE00046-010 & IRR & -64 & -19 & 184 & 67,071 \\
\hline ME00518-001 & IRR & -93 & -28 & 172 & 62,600 \\
\hline ME00378-001 & IRR & -41 & -13 & 166 & 60,712 \\
\hline BE00060-002 & IRR & -45 & -14 & 164 & 59,795 \\
\hline ME00316-001 & IRR & 152 & 46 & 163 & 59,619 \\
\hline BE00192-001 & IRR & -335 & -102 & 149 & 54,561 \\
\hline BE00071A-001 & IRR & 90 & 27 & 148 & 54,099 \\
\hline ME00349-002 & IRR & 235 & 72 & 143 & 52,340 \\
\hline ME00415-002 & IRR & -128 & -39 & 136 & 49,682 \\
\hline ME00570-001 & IRR & -116 & -35 & 128 & 46,768 \\
\hline BE00181-001 & IRR & 124 & 38 & 125 & 45,542 \\
\hline ME00384-001 & IRR & 119 & 36 & 122 & 44,551 \\
\hline BE00267-001 & IRR & -331 & -101 & 118 & 42,975 \\
\hline ME00339-001 & IRR & 34 & 10 & 106 & 38,628 \\
\hline ME00469-001 & IRR & 89 & 27 & 65 & 23,599 \\
\hline BE00207-002 & IRR & -16 & -5 & 64 & 23,452 \\
\hline BE00022-001 & IRR & -265 & -81 & 61 & 22,362 \\
\hline BE00046-007 & IRR & -66 & -20 & 61 & 22,357 \\
\hline ME00354-002 & IRR & 178 & 54 & 55 & 20,124 \\
\hline ME00579-001 & IRR & -106 & -32 & 53 & 19,483 \\
\hline ME00523-001 & IRR & -28 & -9 & 48 & 17,438 \\
\hline ME00382-001 & IRR & 55 & 17 & 48 & 17,351 \\
\hline BE00046-008 & IRR & -66 & -20 & 41 & 14,905 \\
\hline BE00197-002 & IRR & -33 & -10 & 40 & 14,619 \\
\hline BE00024-001 & IRR & -332 & -101 & 35 & 12,769 \\
\hline ME00308-001 & IRR & 5 & 1 & 30 & 10,982 \\
\hline ME00540-001 & IRR & -108 & -33 & 27 & 9,754 \\
\hline
\end{tabular}


Table 5. Mean daily and mean annual groundwater-withdrawal rates from municipal, industrial, irrigation, and livestock wells in the local-scale study area during 2001, San Antonio region, Texas.-Continued

[Locations of wells are shown in figure 14; MUN, municipal well; IND, industrial well; IRR, irrigation well; STK, livestock well. Withdrawal rates provided by San Antonio Water System (2008), Bexar Metropolitan Water District, and Edwards Aquifer Authority (2009)]

\begin{tabular}{|c|c|c|c|c|c|}
\hline $\begin{array}{c}\text { Well } \\
\text { number }\end{array}$ & $\begin{array}{l}\text { Water use } \\
\text { type }\end{array}$ & $\begin{array}{c}\text { Altitude of top of } \\
\text { open interval } \\
\text { (meters) }\end{array}$ & $\begin{array}{c}\text { Altitude of bottom } \\
\text { of open interval } \\
\text { (meters) }\end{array}$ & $\begin{array}{c}\text { Withdrawal rate } \\
\text { (cubic meters per day) }\end{array}$ & $\begin{array}{c}\text { Withdrawal rate } \\
\text { (cubic meters per year) }\end{array}$ \\
\hline ME00573-001 & IRR & -122 & -37 & 26 & 9,566 \\
\hline BE00187-001 & IRR & 103 & 31 & 23 & 8,334 \\
\hline BE00020-001 & IRR & -324 & -99 & 21 & 7,627 \\
\hline ME00572-001 & IRR & 23 & 7 & 18 & 6,716 \\
\hline BE00053-001 & IRR & 7 & 2 & 12 & 4,227 \\
\hline ME00315-001 & IRR & -91 & -28 & 9 & 3,289 \\
\hline BE00247-001 & IRR & 34 & 10 & 8 & 2,931 \\
\hline BE00115-001 & IRR & 133 & 40 & 7 & 2,484 \\
\hline BE00156-001 & IRR & 119 & 36 & 3 & 1,172 \\
\hline ME00510-001 & IRR & 39 & 12 & 2 & 646 \\
\hline BE00118-001 & IRR & -293 & -89 & 1 & 362.7 \\
\hline BE00274-001 & IRR & -260 & -79 & 1 & 248.4 \\
\hline BE00198-001 & IRR & 196 & 60 & 0 & 165.1 \\
\hline BE00172-001 & IRR & 124 & 38 & 0.1 & 36.59 \\
\hline BE00046-006 & IRR & -66 & -20 & 0.0 & 7.44 \\
\hline BE00046-011 & IRR & -64 & -19 & 0.0 & 7.44 \\
\hline Subtotal & & & & $124,896.9$ & $45,587,377$ \\
\hline
\end{tabular}


Table 6. Measured and simulated water-level altitudes and springflows and the differences between measured and simulated waterlevel altitudes and springflows (residuals) for the local-scale model, steady-state simulation, San Antonio region, Texas.

[Hydrogeologic unit numbers refer to hydrogeologic units as follows: 1 is overburden, 2 is Georgetown, 3 is cyclic and marine, 4 is leached and collapsed, 5 is upper high $\mathrm{K}$ (conduit), 6 is regional dense, 7 is grainstone, 8 is Kirschberg evaporite, 9 is lower high $\mathrm{K}$ (conduit), 10 is dolomitic, 11 is basal nodular, 12 is Glen Rose (Trinity Group); Measured value is the mean hydraulic head or springflow measured during 2001. Difference or residual is the measured water level or springflow minus the simulated water level or springflow. $\mathrm{m}$, meters; $\mathrm{m}^{3} \mathrm{~s}$, cubic meters per second; RMS, root mean square]

\begin{tabular}{|c|c|c|c|c|c|c|}
\hline \multirow{2}{*}{$\begin{array}{l}\text { Well } \\
\text { name }\end{array}$} & \multirow{2}{*}{$\begin{array}{c}\text { Well } \\
\text { identifier }\end{array}$} & \multirow{2}{*}{$\begin{array}{l}\text { Hydrogeologic unit } \\
\text { number(s) }\end{array}$} & \multicolumn{2}{|c|}{$\begin{array}{l}\text { Water-level altitude } \\
(\mathrm{m})\end{array}$} & \multicolumn{2}{|c|}{$\begin{array}{c}\text { Difference } \\
(\mathrm{m})\end{array}$} \\
\hline & & & $\begin{array}{l}\text { Measured } \\
\text { value }\end{array}$ & $\begin{array}{l}\text { Simulated } \\
\text { value }\end{array}$ & $\begin{array}{l}\text { Algebraic } \\
\text { difference }\end{array}$ & $\begin{array}{l}\text { Absolute value } \\
\text { of difference }\end{array}$ \\
\hline 6827307 & W1 & 11 & 245.7 & 241.8 & 3.9 & 3.9 \\
\hline 6827401 & W2 & $4-10$ & 241.2 & 235.0 & 6.3 & 6.3 \\
\hline 6827517 & W3 & $7-8$ & 238.0 & 244.3 & -6.2 & 6.2 \\
\hline 6827610 & W5 & $4-6$ & 223.5 & 215.0 & 8.5 & 8.5 \\
\hline 6827611 & W6 & 4 & 232.7 & 229.6 & 3.1 & 3.1 \\
\hline 6827612 & W7 & $3-4$ & 230.6 & 228.7 & 1.8 & 1.8 \\
\hline 6828113 & W8 & $7-8$ & 243.1 & 241.9 & 1.2 & 1.2 \\
\hline 6828314 & W12 & $7-8$ & 220.7 & 219.3 & 1.3 & 1.3 \\
\hline 6828315 & W13 & 12 & 223.9 & 226.1 & -2.2 & 2.2 \\
\hline 6828406 & W14 & $6-8$ & 223.1 & 219.3 & 3.8 & 3.8 \\
\hline 6828407 & W15 & $7-8$ & 224.3 & 227.3 & -3.0 & 3.0 \\
\hline 6828512 & W16 & $6-12$ & 232.8 & 226.4 & 6.4 & 6.4 \\
\hline 6828515 & W17 & 6 & 218.5 & 211.0 & 7.5 & 7.5 \\
\hline 6828516 & W18 & $6-7$ & 226.9 & 215.5 & 11.4 & 11.4 \\
\hline 6828518 & W19 & 6 & 218.1 & 216.3 & 1.8 & 1.8 \\
\hline 6828519 & W20 & $6-7$ & 218.3 & 213.1 & 5.2 & 5.2 \\
\hline 6829112 & W27 & $6-9$ & 220.0 & 214.4 & 5.6 & 5.6 \\
\hline 6829113 & W28 & 1 & 220.3 & 212.3 & 8.1 & 8.1 \\
\hline 6829418 & W29 & 1 & 215.9 & 207.8 & 8.1 & 8.1 \\
\hline 6835106 & W30 & 3-11 & 205.7 & 210.4 & -4.8 & 4.8 \\
\hline 6835202 & W31 & $1-3$ & 210.5 & 209.8 & .7 & .7 \\
\hline 6836103 & W32 & $1-11$ & 202.9 & 207.1 & -4.3 & 4.3 \\
\hline 6836130 & W33 & 3-11 & 201.3 & 206.3 & -5.0 & 5.0 \\
\hline 6836206 & W34 & $2-7$ & 206.1 & 205.9 & .2 & .2 \\
\hline 6836502 & W35 & $2-11$ & 205.7 & 206.9 & -1.3 & 1.3 \\
\hline 6836901 & W36 & $2-4$ & 205.8 & 207.0 & -1.2 & 1.2 \\
\hline 6837103 & W37 & $3-11$ & 205.1 & 205.3 & -.3 & .3 \\
\hline 6837203 & W38 & $1-6$ & 204.6 & 205.4 & -.9 & .9 \\
\hline
\end{tabular}


Table 6. Measured and simulated water-level altitudes and springflows and the differences between measured and simulated waterlevel altitudes and springflows (residuals) for the local-scale model, steady-state simulation, San Antonio region, Texas.-Continued

[Hydrogeologic unit numbers refer to hydrogeologic units as follows: 1 is overburden, 2 is Georgetown, 3 is cyclic and marine, 4 is leached and collapsed, 5 is upper high $\mathrm{K}$ (conduit), 6 is regional dense, 7 is grainstone, 8 is Kirschberg evaporite, 9 is lower high $\mathrm{K}$ (conduit), 10 is dolomitic, 11 is basal nodular, 12 is Glen Rose (Trinity Group); Measured value is the mean hydraulic head or springflow measured during 2001. Difference or residual is the measured water level or springflow minus the simulated water level or springflow. $\mathrm{m}$, meters; $\mathrm{m}^{3} / \mathrm{s}$, cubic meters per second; RMS, root mean square]

\begin{tabular}{|c|c|c|c|c|c|c|}
\hline \multirow{2}{*}{$\begin{array}{l}\text { Well } \\
\text { name }\end{array}$} & \multirow{2}{*}{$\begin{array}{l}\text { Well } \\
\text { identifier }\end{array}$} & \multirow{2}{*}{$\begin{array}{l}\text { Hydrogeologic unit } \\
\text { number(s) }\end{array}$} & \multicolumn{2}{|c|}{$\begin{array}{c}\text { Water-level altitude } \\
(\mathrm{m})\end{array}$} & \multicolumn{2}{|c|}{$\begin{array}{c}\text { Difference } \\
(\mathrm{m})\end{array}$} \\
\hline & & & $\begin{array}{l}\text { Measured } \\
\text { value }\end{array}$ & $\begin{array}{l}\text { Simulated } \\
\text { value }\end{array}$ & $\begin{array}{l}\text { Algebraic } \\
\text { difference }\end{array}$ & $\begin{array}{l}\text { Absolute value } \\
\text { of difference }\end{array}$ \\
\hline 6837304 & W39 & 1 & 202.1 & 204.9 & -2.8 & 2.8 \\
\hline 6837524 & W40 & 1 & 205.1 & 206.6 & -1.5 & 1.5 \\
\hline 6843402 & W41 & $1-10$ & 206.8 & 209.6 & -2.8 & 2.8 \\
\hline $68285 \mathrm{AA}$ & W43 & $1-11$ & 184.8 & 207.9 & -23.0 & 23.0 \\
\hline 68299BB & W44 & $3-11$ & 203.5 & 204.1 & -.6 & .6 \\
\hline 68299CC & W45 & $3-11$ & 204.0 & 204.1 & -.1 & .1 \\
\hline 68377AA & W46 & $3-11$ & 197.1 & 207.0 & -9.9 & 9.9 \\
\hline 6833604 & W50 & $1-3$ & 215.6 & 212.7 & 2.9 & 2.9 \\
\hline 6834506 & W51 & 3-11 & 212.6 & 212.5 & .1 & .1 \\
\hline 6841301 & W52 & $3-4$ & 213.4 & 212.6 & .9 & .9 \\
\hline 6842106 & W53 & $1-4$ & 213.5 & 212.5 & 1.0 & 1.0 \\
\hline 6842112 & W54 & 3 & 209.9 & 209.9 & 0 & 0 \\
\hline 6842502 & W55 & $2-4$ & 211.5 & 209.7 & 1.8 & 1.8 \\
\hline 6939504 & W56 & 1 & 262.7 & 253.6 & 9.1 & 9.1 \\
\hline 6939801 & W57 & $1-4$ & 230.0 & 220.3 & 9.7 & 9.7 \\
\hline 6939901 & W58 & $6-11$ & 228.1 & 220.2 & 7.9 & 7.9 \\
\hline 6948102 & W65 & $4-10$ & 218.7 & 215.7 & 3.0 & 3.0 \\
\hline 6948303 & W66 & $7-10$ & 213.9 & 215.5 & -1.6 & 1.6 \\
\hline 68339AA & W67 & $4-11$ & 214.6 & 212.6 & 1.9 & 1.9 \\
\hline $68415 \mathrm{AA}$ & W68 & $1-11$ & 214.3 & 210.0 & 4.3 & 4.3 \\
\hline 68416AA & W69 & $1-11$ & 213.0 & 209.9 & 3.1 & 3.1 \\
\hline $68422 \mathrm{AA}$ & W70 & $1-8$ & 211.5 & 210.0 & 1.5 & 1.5 \\
\hline 69396AA & W71 & $1-10$ & 241.9 & 238.5 & 3.3 & 3.3 \\
\hline 69489AA & W72 & $1-7$ & 223.5 & 212.7 & 10.8 & 10.8 \\
\hline YMCA & W73 & $3-10$ & 219.2 & 210.6 & 8.7 & 8.7 \\
\hline Graham & W74 & $1-11$ & 218.2 & 210.6 & 7.7 & 7.7 \\
\hline Lockhill & W75 & 9-11 & 228.5 & 209.7 & 18.8 & 18.8 \\
\hline Abe Lincoln & W76 & $2-11$ & 214.4 & 209.0 & 5.4 & 5.4 \\
\hline
\end{tabular}


Table 6. Measured and simulated water-level altitudes and springflows and the differences between measured and simulated waterlevel altitudes and springflows (residuals) for the local-scale model, steady-state simulation, San Antonio region, Texas. - Continued

[Hydrogeologic unit numbers refer to hydrogeologic units as follows: 1 is overburden, 2 is Georgetown, 3 is cyclic and marine, 4 is leached and collapsed, 5 is upper high $\mathrm{K}$ (conduit), 6 is regional dense, 7 is grainstone, 8 is Kirschberg evaporite, 9 is lower high $\mathrm{K}$ (conduit), 10 is dolomitic, 11 is basal nodular, 12 is Glen Rose (Trinity Group); Measured value is the mean hydraulic head or springflow measured during 2001. Difference or residual is the measured water level or springflow minus the simulated water level or springflow. $\mathrm{m}$, meters; $\mathrm{m}^{3} \mathrm{~s}$, cubic meters per second; RMS, root mean square]

\begin{tabular}{|c|c|c|c|c|c|c|}
\hline \multirow{2}{*}{$\begin{array}{l}\text { Well } \\
\text { name }\end{array}$} & \multirow{2}{*}{$\begin{array}{c}\text { Well } \\
\text { identifier }\end{array}$} & \multirow{2}{*}{$\begin{array}{l}\text { Hydrogeologic unit } \\
\text { number(s) }\end{array}$} & \multicolumn{2}{|c|}{$\begin{array}{l}\text { Water-level altitude } \\
(\mathrm{m})\end{array}$} & \multicolumn{2}{|c|}{$\begin{array}{l}\text { Difference } \\
\quad(\mathrm{m})\end{array}$} \\
\hline & & & $\begin{array}{l}\text { Measured } \\
\text { value }\end{array}$ & $\begin{array}{l}\text { Simulated } \\
\text { value }\end{array}$ & $\begin{array}{l}\text { Algebraic } \\
\text { difference }\end{array}$ & $\begin{array}{l}\text { Absolute value } \\
\text { of difference }\end{array}$ \\
\hline Propane Depot & W77 & $1-10$ & 209.7 & 208.8 & 0.9 & 0.9 \\
\hline Salazar & W78 & $1-11$ & 213.3 & 208.0 & 5.4 & 5.4 \\
\hline $\begin{array}{l}\text { Zarzamora } \\
\text { OVB }\end{array}$ & W79 & 1 & 212.9 & 207.2 & 5.7 & 5.7 \\
\hline Timberhill_IED & WQ1 & $4-6$ & 205.0 & 208.2 & -3.2 & 3.2 \\
\hline $\begin{array}{l}\text { Timberhill_ } \\
\text { DED }\end{array}$ & WQ2 & $8-10$ & 205.1 & 208.2 & -3.1 & 3.1 \\
\hline Zarzamora_SED & WQ3 & 3 & 206.5 & 207.2 & -.7 & .7 \\
\hline Zarzamora_IED & WQ4 & 4 & 207.4 & 207.2 & .2 & .2 \\
\hline $\begin{array}{l}\text { Zarzamora } \\
\text { DED }\end{array}$ & WQ5 & $7-8$ & 206.1 & 207.2 & -1.1 & 1.1 \\
\hline Mean & & & & & 1.9 & 4.2 \\
\hline RMS error & & & & & & 6.0 \\
\hline
\end{tabular}

\begin{tabular}{|c|c|c|c|c|c|}
\hline \multirow{2}{*}{$\begin{array}{l}\text { Spring } \\
\text { name }\end{array}$} & \multirow{2}{*}{$\begin{array}{c}\text { Spring } \\
\text { identifier }\end{array}$} & \multirow{2}{*}{$\begin{array}{l}\text { Hydrogeologic unit } \\
\text { number(s) }\end{array}$} & \multicolumn{3}{|c|}{ Springflow $\left(\mathbf{m}^{3} / \mathbf{s}\right)$} \\
\hline & & & Measured value & Simulated value & Residual \\
\hline San Antonio & DR1 & $2-11$ & 0.91 & 0.98 & -0.07 \\
\hline San Pedro & DR2 & $2-11$ & .24 & .23 & .01 \\
\hline RMS error & & & & & .05 \\
\hline
\end{tabular}


Table 7. Hydrogeologic units used in the local-scale model, San Antonio region, Texas.

[Thickness of hydrogeologic unit number 1 (overburden) is computed as the difference between land surface altitude and the altitude of the top of the uppermost unit of the Edwards aquifer (hydrogeologic units 2-11) present at a location; much of the thickness is unsaturated]

\begin{tabular}{lccccc}
\hline \multirow{2}{*}{$\begin{array}{c}\text { Hydrogeologic } \\
\text { unit }\end{array}$} & $\begin{array}{c}\text { Hydrogeologic } \\
\text { unit number }\end{array}$ & \multicolumn{3}{c}{$\begin{array}{c}\text { Thickness } \\
\text { (meters) }\end{array}$} & $\begin{array}{c}\text { Number of active } \\
\text { model cells }\end{array}$ \\
\cline { 3 - 5 } & & Minimum & Mean & Maximum & \\
\hline overburden & 1 & 0.3 & 281 & 759 & 55,778 \\
Georgetown & 2 & .6 & 7 & 21 & 57,333 \\
cyclic and marine & 3 & 8 & 21 & 40 & 57,333 \\
leached and collapsed & 4 & 8 & 25 & 51 & 57,333 \\
upper high K (conduit) & 5 & 8 & 8 & 8 & 57,333 \\
regional dense & 6 & 3 & 7 & 12 & 57,906 \\
grainstone & 7 & 10 & 17 & 44 & 57,906 \\
Kirschberg evaporite & 8 & 2 & 10 & 20 & 57,906 \\
lower high K (conduit) & 9 & 8 & 8 & 8 & 57,906 \\
dolomitic & 10 & 13 & 36 & 44 & 57,906 \\
basal nodular & 11 & 13 & 17 & 26 & 65,869 \\
Glen Rose (Trinity Group) & 12 & 3 & 139 & 291 & 13,492 \\
\hline
\end{tabular}

Table 8. Summary of specified flux by model boundary in the local-scale model, San Antonio region, Texas.

[Subtotal is the sum of the flows for the western, southern, and eastern model boundaries. Total is the sum of the flows for the northern, western, southern, and eastern model boundaries. Negative flow indicates flow out of the local-scale model area. The net flows from this table are shown in figure 24 , adjusted for the different units of measure used in figure 24 (cubic meters per year)]

\begin{tabular}{lrrrrrr}
\hline \multirow{2}{*}{$\begin{array}{c}\text { Flow } \\
\text { direction }\end{array}$} & \multicolumn{5}{c}{ Specified flux by model boundary, in cubic meters per day } \\
\cline { 2 - 7 } & Northern & Western & Southern & \multicolumn{1}{c}{ Eastern } & \multicolumn{1}{c}{ Subtotal } & Total \\
\hline Inflow & 32,385 & $1,108,927$ & 754,201 & 9,190 & $1,872,318$ & $1,904,703$ \\
Outflow & 0 & $-122,893$ & $-1,081,631$ & $-791,203$ & $-1,995,727$ & $-1,995,727$ \\
Net flow & 32,385 & 986,034 & $-327,430$ & $-782,013$ & $-123,409$ & $-91,024$ \\
\hline
\end{tabular}


Table 9. Initial and calibrated values for hydraulic conductivity parameters used in the local-scale groundwater-flow and particletracking simulations, San Antonio region, Texas.

[Hydrogeologic unit numbers refer to hydrogeologic units as follows: 1 is overburden, 2 is Georgetown, 3 is cyclic and marine, 4 is leached and collapsed, 5 is upper high $\mathrm{K}$ (conduit), 6 is regional dense, 7 is grainstone, 8 is Kirschberg evaporite, 9 is lower high $\mathrm{K}$ (conduit), 10 is dolomitic, 11 is basal nodular, 12 is Glen Rose (Trinity Group); HK, horizontal hydraulic conductivity; HANI, horizontal anisotropy; VANI, vertical anisotropy; HK1 to HK12 are base horizontal hydraulic conductivity values referred to in text and figures 16-17; horizontal aisotropy is the ratio of hydraulic conductivity along columns to hydraulic conductivity along rows; vertical anisotropy is the ratio of horizontal to vertical hydraulic conductivity; horizontal hydraulic conductivity is in meters per day; horizontal anisotropy and vertical anisotropy are dimensionless]

\begin{tabular}{|c|c|c|c|}
\hline $\begin{array}{c}\text { Param- } \\
\text { eter }\end{array}$ & $\begin{array}{c}\text { Hydrogeologic } \\
\text { unit number }\end{array}$ & Initial value & Calibrated value \\
\hline HK1 & 1 & 3.0 & 12.1 \\
\hline HK2 & 2 & 3.0 & 2.84 \\
\hline HK3 & 3 & 152 & 497 \\
\hline HK4 & 4 & 152 & 497 \\
\hline HK5 & 5 & 152,393 & 152,393 \\
\hline HK6 & 6 & 3.0 & 2.92 \\
\hline HK7 & 7 & 91 & 83.5 \\
\hline HK8 & 8 & 152 & 256 \\
\hline HK9 & 9 & 152,393 & 115,818 \\
\hline HK10 & 10 & 91 & 9.14 \\
\hline HK11 & 11 & 3.0 & 5.39 \\
\hline HK12 & 12 & 1.5 & 5.76 \\
\hline HK13 & $2-4,6-8,10-11$ & 4,572 & 6,584 \\
\hline HK14 & $2-4,6-8,10-11$ & 3,810 & 4,073 \\
\hline HK15 & $2-4,6-8,10-11$ & 3,048 & 5,863 \\
\hline HK16 & $2-4,6-8,10-11$ & 3,048 & 5,227 \\
\hline HK17 & $2-4,6-8,10-11$ & 3,048 & 4,297 \\
\hline HK18 & $2-4,6-8,10-11$ & 1.5 & .35 \\
\hline HK19 & $2-4,6-8,10-11$ & 1.5 & 2.56 \\
\hline HK20 & $2-4,6-8,10-11$ & 1.5 & 2.50 \\
\hline HK21 & $2-4,6-8,10-11$ & 3.0 & 1.59 \\
\hline HK22 & $2-4,6-8,10-11$ & 3.0 & 2.18 \\
\hline HK23 & $2-4,6-8,10-11$ & 3.0 & 17.3 \\
\hline HK24 & 5,9 & 3.0 & 515 \\
\hline HK25 & 5,9 & 3.0 & 4.39 \\
\hline HK26 & 5,9 & 3.0 & 688 \\
\hline
\end{tabular}

\begin{tabular}{|c|c|c|c|}
\hline $\begin{array}{c}\text { Param- } \\
\text { eter }\end{array}$ & $\begin{array}{c}\text { Hydrogeologic } \\
\text { unit number }\end{array}$ & Initial value & Calibrated value \\
\hline HK27 & 5,9 & 30 & 37.8 \\
\hline HK28 & 5,9 & 30 & 923 \\
\hline HK29 & 5,9 & 3.0 & 1.52 \\
\hline HK30 & $2-4,6-8,10-12$ & 152 & 153 \\
\hline HK31 & $2-4,6-8,10-12$ & 152 & 322 \\
\hline HK32 & $2-4,6-8,10-12$ & 152 & 146 \\
\hline HK33 & $2-4,6-8,10-12$ & 152 & 107 \\
\hline HANI1 & All & 1.0 & 1.0 \\
\hline HANI2 & All & .1 & .9 \\
\hline HANI3 & All & 1.0 & .5 \\
\hline HANI4 & All & 1.0 & 1.0 \\
\hline HANI5 & All & 1.0 & .2 \\
\hline HANI6 & All & 1.0 & 1.0 \\
\hline VANI1 & 1 & .1 & .1 \\
\hline VANI2 & 2 & .1 & .2 \\
\hline VANI3 & 3 & 10 & 17.03495 \\
\hline VANI4 & 4 & 10 & 1.0 \\
\hline VANI5 & 5 & 10 & 10 \\
\hline VANI6 & 6 & .1 & .2 \\
\hline VANI7 & 7 & 10 & .55224 \\
\hline VANI8 & 8 & 10 & 15.7668 \\
\hline VANI9 & 9 & 10 & 53.50458 \\
\hline VANI10 & 10 & 10 & .5 \\
\hline VANI11 & 11 & .1 & 5.0 \\
\hline VANI12 & 12 & .1 & .28165 \\
\hline
\end{tabular}


Table 10. Initial and calibrated values for additional parameters used in the local-scale groundwater-flow and particle-tracking simulations, San Antonio region, Texas.

[Hydrogeologic unit numbers refer to hydrogeologic units as follows: 1 is overburden, 2 is Georgetown, 3 is cyclic and marine, 4 is leached and collapsed, 5 is upper high $\mathrm{K}$ (conduit), 6 is regional dense, 7 is grainstone, 8 is Kirschberg evaporite, 9 is lower high $\mathrm{K}$ (conduit), 10 is dolomitic, 11 is basal nodular, 12 is Glen Rose (Trinity Group); DR1, drain conductance for San Antonio Springs; DR2, drain conductance for San Pedro Springs; HFB1HFB5, hydraulic conductance for fault reaches 1-5; POR1-POR12, effective porosity for hydrogeologic units 1-12; drain conductance is in meters squared per day; fault conductance is per day; effective porosity is dimensionless]

\begin{tabular}{lccc}
\hline $\begin{array}{c}\text { Param- } \\
\text { eter }\end{array}$ & $\begin{array}{c}\text { Hydrogeo- } \\
\text { logic unit } \\
\text { number }\end{array}$ & Initial value & Calibrated value \\
\cline { 1 - 3 } DR1 & $2-11$ & 613,100 & \multicolumn{2}{c}{$\begin{array}{l}\text { 455,210 } \\
\text { DR2 }\end{array}$} & $2-11$ & 3,066 & 4,738 \\
HFB1 & All & .000000001 & .01 \\
HFB2 & All & .00000001 & .1 \\
HFB3 & All & .00001 & .1 \\
HFB4 & All & .01 & .1 \\
HFB5 & All & .02 & .2 \\
POR1 & 1 & .001 & .002909 \\
POR2 & 2 & .001 & .009217 \\
POR3 & 3 & .01 & .001795 \\
POR4 & 4 & .01 & .003944 \\
POR5 & 5 & .0001 & .0005373 \\
POR6 & 6 & .001 & .0009396 \\
POR7 & 7 & .01 & .005700 \\
POR8 & 8 & .01 & .001914 \\
POR9 & 9 & .0001 & .00009296 \\
POR10 & 10 & .01 & .01255 \\
POR11 & 11 & .001 & .01241 \\
POR12 & 12 & .001 & .008111 \\
\hline
\end{tabular}


Table 11. Measured and simulated tritium concentrations and the differences between measured and simulated tritium concentrations (residuals) for the local-scale model, steady-state simulation, San Antonio region, Texas.

[Hydrogeologic unit numbers refer to hydrogeologic units as follows: 1 is overburden, 2 is Georgetown, 3 is cyclic and marine, 4 is leached and collapsed, 5 is upper high $\mathrm{K}$ (conduit), 6 is regional dense, 7 is grainstone, 8 is Kirschberg evaporite, 9 is lower high $\mathrm{K}$ (conduit), 10 is dolomitic, 11 is basal nodular, 12 is Glen Rose (Trinity Group); WZ4W is wellhead sample for well WZ4; WZ4S is shallow depth-dependent sampling interval for well WZ4; WZ4I is intermediate depth-dependent sampling interval for well WZ4; WZ4D is deep depth-dependent sampling interval for well WZ4; WZ5W is wellhead sample for well WZ5; WZ6W is wellhead sample for well WZ6; WZ2W is wellhead sample for well WZ2; WZ3W is wellhead sample for well WZ3. RMS, root mean square]

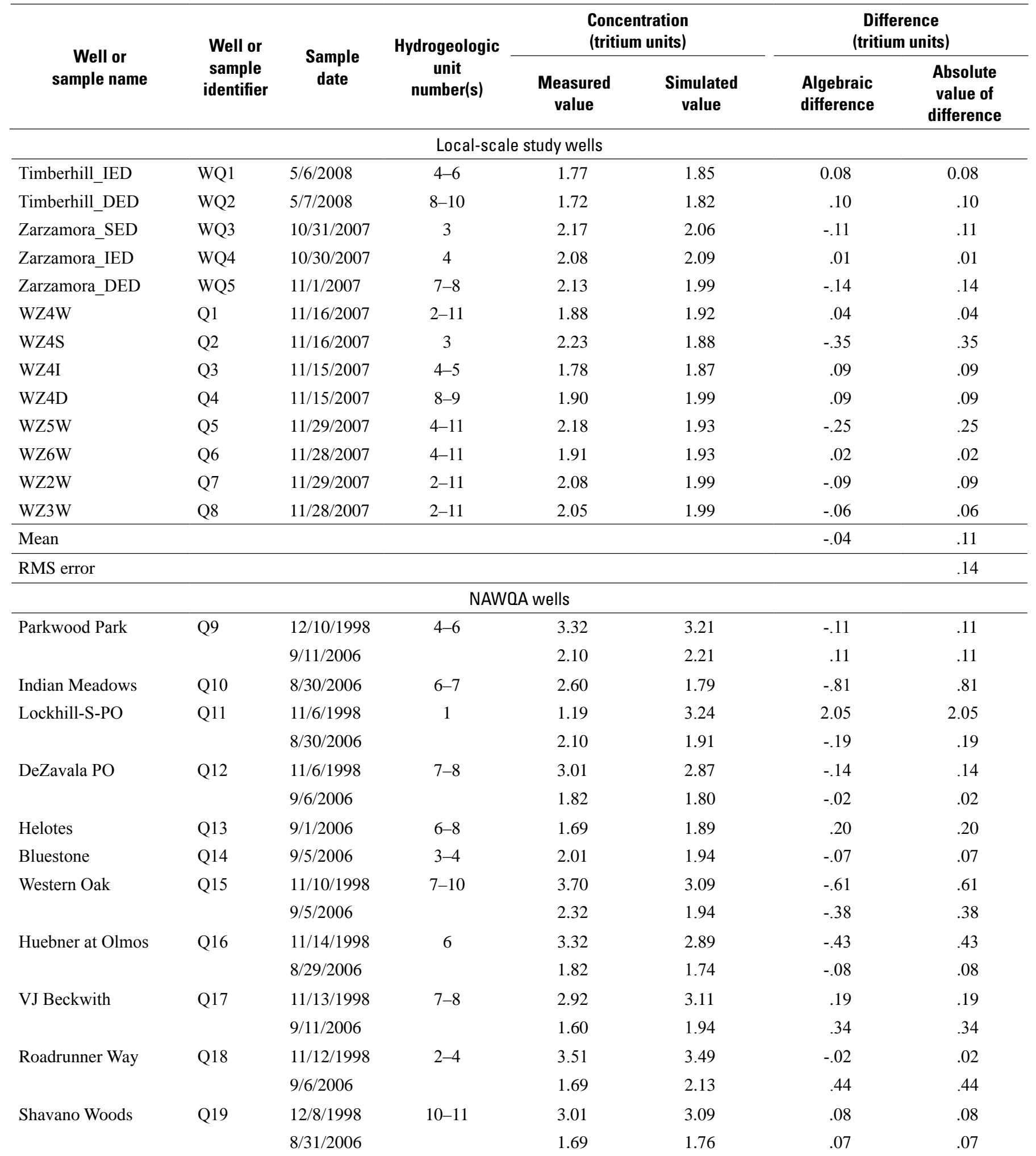


Table 11. Measured and simulated tritium concentrations and the differences between measured and simulated tritium concentrations (residuals) for the local-scale model, steady-state simulation, San Antonio region, Texas.-Continued

[Hydrogeologic unit numbers refer to hydrogeologic units as follows: 1 is overburden, 2 is Georgetown, 3 is cyclic and marine, 4 is leached and collapsed, 5 is upper high $\mathrm{K}$ (conduit), 6 is regional dense, 7 is grainstone, 8 is Kirschberg evaporite, 9 is lower high $\mathrm{K}$ (conduit), 10 is dolomitic, 11 is basal nodular, 12 is Glen Rose (Trinity Group); WZ4W is wellhead sample for well WZ4; WZ4S is shallow depth-dependent sampling interval for well WZ4; WZ4I is intermediate depth-dependent sampling interval for well WZ4; WZ4D is deep depth-dependent sampling interval for well WZ4; WZ5W is wellhead sample for well WZ5; WZ6W is wellhead sample for well WZ6; WZ2W is wellhead sample for well WZ2; WZ3W is wellhead sample for well WZ3. RMS, root mean square]

\begin{tabular}{|c|c|c|c|c|c|c|c|}
\hline \multirow{2}{*}{$\begin{array}{c}\text { Well or } \\
\text { sample name }\end{array}$} & \multirow{2}{*}{$\begin{array}{l}\text { Well or } \\
\text { sample } \\
\text { identifier }\end{array}$} & \multirow{2}{*}{$\begin{array}{l}\text { Sample } \\
\text { date }\end{array}$} & \multirow{2}{*}{$\begin{array}{c}\text { Hydrogeologic } \\
\text { unit } \\
\text { number(s) }\end{array}$} & \multicolumn{2}{|c|}{$\begin{array}{l}\text { Concentration } \\
\text { (tritium units) }\end{array}$} & \multicolumn{2}{|c|}{$\begin{array}{c}\text { Difference } \\
\text { (tritium units) }\end{array}$} \\
\hline & & & & $\begin{array}{l}\text { Measured } \\
\text { value }\end{array}$ & $\begin{array}{l}\text { Simulated } \\
\text { value }\end{array}$ & $\begin{array}{l}\text { Algebraic } \\
\text { difference }\end{array}$ & $\begin{array}{c}\text { Absolute } \\
\text { value of } \\
\text { difference }\end{array}$ \\
\hline \multirow[t]{2}{*}{ SP-Cliffside } & Q20 & $12 / 11 / 1998$ & 6 & 2.01 & 3.25 & 1.24 & 1.24 \\
\hline & & $8 / 24 / 2006$ & & 2.19 & 1.74 & -.45 & .45 \\
\hline Babcock Firestation & & 9/7/2006 & & 2.51 & 1.94 & -.57 & .57 \\
\hline \multirow[t]{2}{*}{ SP-Fawn Drive } & Q22 & $11 / 14 / 1998$ & $10-11$ & 2.82 & 3.46 & .64 & .64 \\
\hline & & $8 / 24 / 2006$ & & 1.16 & 1.77 & .61 & .61 \\
\hline UTSA at Regency & Q23 & $11 / 12 / 1998$ & $6-7$ & 3.10 & 3.16 & .06 & .06 \\
\hline Landrum & Q25 & 8/22/1996 & $1-4$ & 4.01 & 4.29 & .28 & .28 \\
\hline O. Martin & Q26 & $7 / 24 / 1996$ & $4-8$ & 3.13 & 3.55 & .42 & .42 \\
\hline Wiemers & Q27 & 7/22/1996 & $1-10$ & 2.82 & 3.87 & 1.05 & 1.05 \\
\hline Lehmberg & Q28 & 8/1/1996 & $1-10$ & 1.19 & 3.81 & 2.62 & 2.62 \\
\hline Walthour & Q29 & 7/23/1996 & 12 & 4.39 & 3.80 & -.59 & .59 \\
\hline Shavano Park (no. 6) & Q30 & 8/6/1996 & $11-12$ & 1.19 & 3.96 & 2.77 & 2.77 \\
\hline 34th St Sta & Q31 & 6/26/1997 & $1-11$ & 2.70 & 3.51 & .81 & .81 \\
\hline Lockhill-Selma & Q32 & 7/7/1997 & $3-5$ & 3.92 & 3.62 & -.30 & .30 \\
\hline Fohn Farms & Q33 & 7/8/1997 & $2-7$ & 0.91 & 4.43 & 3.52 & 3.52 \\
\hline
\end{tabular}




\section{Simulations of Groundwater Flow and Particle-Tracking Analysis in the Zone of Contribution to a Public-Supply Well}

Table 12. Simulated annual water budget for the local-scale model, steady-state simulation, San Antonio region, Texas.

[Recharge includes leakage from streams through streambeds and infiltration of precipitation in interstream areas. Boundary inflow includes inflow through specified-flow boundary condition cells at the northern, western, southern, and eastern model boundaries. $\mathrm{m}^{3} / \mathrm{yr}$, cubic meters per year]

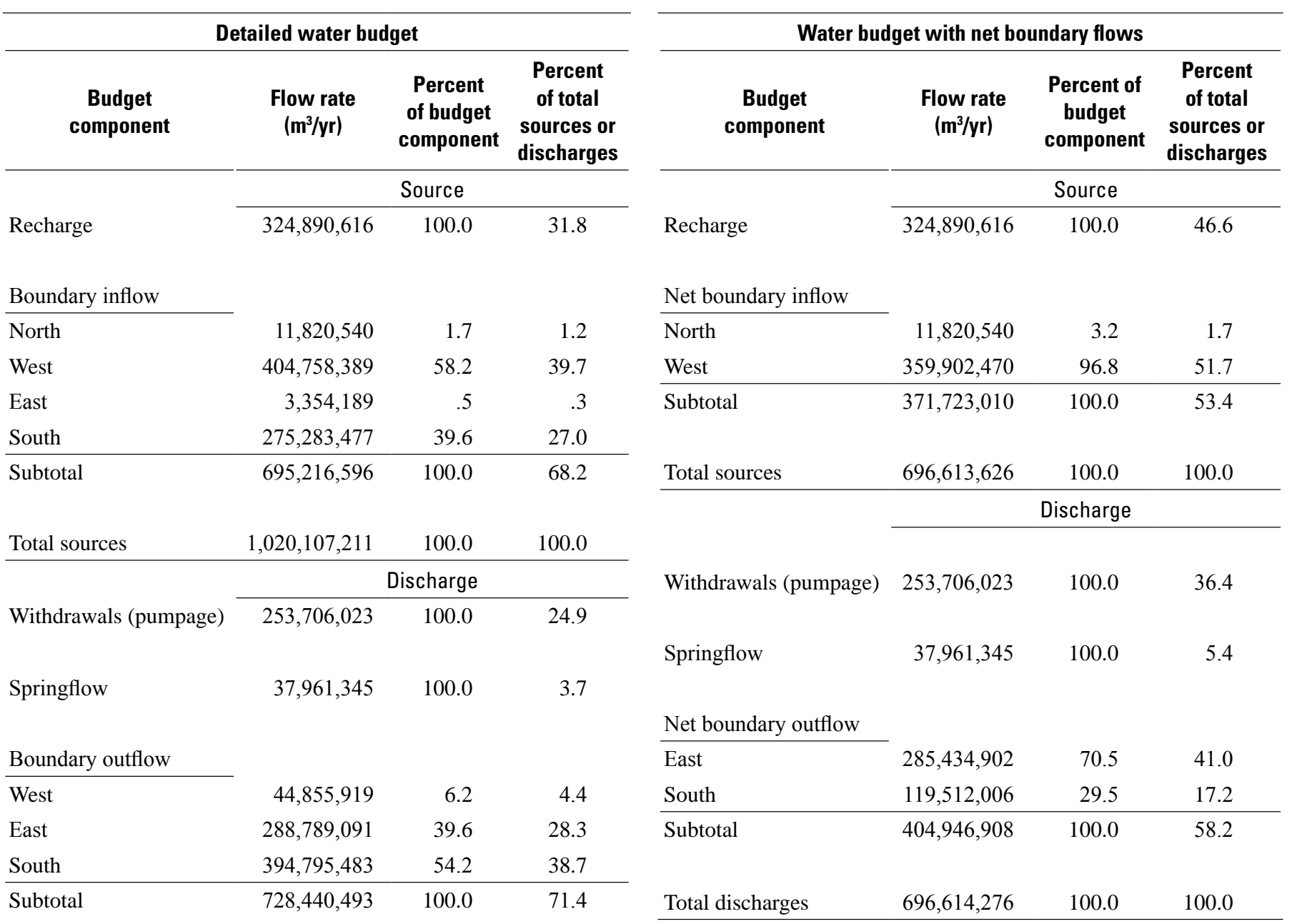

$1,020,107,861 \quad 100.0 \quad 100.0$


Table 13. Simulated particle ages, minimum, mean, and maximum at monitoring wells and at the selected public-supply well, San Antonio region, Texas.

[Simulated particle ages and measured apparent groundwater ages are for pumping conditions with the well field and test well (WZ4) pumping; measured apparent groundwater age is based on ${ }^{3} \mathrm{H} /{ }^{3} \mathrm{He}$ tracer and piston-flow model (Musgrove and others, 2011); ages in years, except where noted. WZ4W is wellhead sample for well WZ4; WZ4S is shallow depth-dependent sampling interval for well WZ4; WZ4I is intermediate depth-dependent sampling interval for well WZ4; WZ4D is deep depth-dependent sampling interval for well WZ4; WZ5W is wellhead sample for well WZ5; WZ6W is wellhead sample for well WZ6; WZ2W is wellhead sample for well WZ2; WZ3W is wellhead sample for well WZ3. Composite refers to all the particles at all the wells (screened at varying depths) for the Timberhill or the Zarzamora well nests. The mean simulated particle ages highlighted in yellow are older than the corresponding measured apparent groundwater ages. The minimum, maximum, and mean simulated particle ages for the NAWQA wells are the composite values for all particles for the 29 NAWQA wells with tritium observations used in this study. <, less than; NA, not applicable; NM, unable to determine an age (Musgrove and others, 2011)]

\begin{tabular}{|c|c|c|c|c|c|}
\hline \multirow{2}{*}{$\begin{array}{c}\text { Well or } \\
\text { sample name }\end{array}$} & \multirow{2}{*}{$\begin{array}{l}\text { Well or sample } \\
\text { identifier }\end{array}$} & \multicolumn{3}{|c|}{ Simulated particle age } & \multirow{2}{*}{$\begin{array}{c}\text { Measured apparen } \\
\text { groundwater age }\end{array}$} \\
\hline & & Minimum & Maximum & Mean & \\
\hline Timberhill_IED & WQ1 & 0.3 & 92 & 2.5 & 41.3 \\
\hline Timberhill_DED & WQ2 & .5 & 621 & 4.9 & 31.6 \\
\hline Composite & & .3 & 621 & 3.7 & \\
\hline Zarzamora_SED & WQ3 & 3.7 & 145 & 15 & 27.5 \\
\hline Zarzamora_IED & WQ4 & 1.1 & 24 & 3.7 & 11.5 \\
\hline Zarzamora_DED & WQ5 & .8 & 16 & 3.7 & 1.3 \\
\hline Composite & & .8 & 145 & 7.6 & \\
\hline WZ4W & Q1 & $<1$ day & 342 & 4.4 & 3.4 \\
\hline WZ4S & Q2 & .4 & 244 & 4.9 & .8 \\
\hline WZ4I & Q3 & .4 & 25 & 2.7 & NM \\
\hline WZ4D & Q4 & $<1$ day & 342 & 4.3 & NM \\
\hline WZ5W & Q5 & $<1$ day & 342 & 4.5 & NM \\
\hline WZ6W & Q6 & $<1$ day & 342 & 4.5 & 16.6 \\
\hline WZ2W & Q7 & .2 & 1,968 & 7.2 & 18.2 \\
\hline WZ3W & Q8 & .2 & 1,968 & 7.2 & 18.4 \\
\hline NAWQA & NA & $<1$ day & 14,767 & 42 & NA \\
\hline
\end{tabular}

Publishing support provided by Lafayette Publishing Service Center 


